\title{
WIDE-ANGLE SEISMIC RECORDINGS FROM THE 1998 SEISMIC HAZARDS INVESTIGATION OF PUGET SOUND (SHIPS), WESTERN WASHINGTON AND BRITISH COLUMBIA
}

by Thomas M. Brocher ${ }^{1}$, Tom Parsons ${ }^{2}$, Ken C. Creager ${ }^{3}$, Robert S. Crosson ${ }^{3}$, Neill P. Symons ${ }^{3}$, George D. Spence ${ }^{4}$, Barry C. Zelt ${ }^{5}$, Philip T.C. Hammer ${ }^{5}$, Roy D. Hyndman ${ }^{6}$, David C. Mosher, Anne M. Trehu', Kate C. Miller ${ }^{8}$, Uri S. ten Brink ${ }^{9}$, Michael A. Fisher ${ }^{2}$, Thomas L. Pratt ${ }^{10}$, Marcos G. Alvarez ${ }^{11}$, Bruce C. Beaudoin ${ }^{11}$, Keith E. Louden ${ }^{12}$, and Craig S. Weaver ${ }^{13}$

Open-File Report 99-314

1999

This report is preliminary and has not been reviewed for conformity with U.S. Geological Survey editorial standards or with the North American Stratigraphic Code. Any use of trade, firm, or product names is for descriptive purposes only and does not imply endorsement by the U.S.

Government.

\section{U.S. DEPARTMENT OF THE INTERIOR}

\section{U.S. GEOLOGICAL SURVEY}

${ }^{1}$ U.S. Geological Survey, 345 Middlefield Road, M/S 977, Menlo Park, CA 94025

2 U.S. Geological Survey, 345 Middlefield Road, M/S 999, Menlo Park, CA 94025

${ }^{3}$ Geophysics, Box 351650, Univ. of Washington, Seattle, WA 98195

${ }_{5}^{4}$ School of Earth and Ocean Sci., Univ. of Victoria, Victoria, B.C., V8W 2Y2, Canada

5 Dept. of Earth and Ocean Sci., Univ. of British Columbia, Vancouver, B.C., V6T 1Z4, Canada

${ }_{7}^{6}$ Pacific Geoscience Centre, Geol. Survey of Canada, Sidney, B.C., V8L 4B2, Canada

${ }_{8}^{7}$ College of Oceanic and Atmospheric Sci., Oregon State Univ., Corvallis, OR 97331

8 Dept. of Geol. Sci., Univ. Texas, El Paso, TX 79968

${ }^{9}$ U.S. Geological Survey, Woods Hole, MA 02543

10 U.S. Geological Survey, School of Oceanography, Box 357940, Univ. Washington, Seattle, WA 98195

11 PASSCAL Instrument Center, New Mexico Tech, 801 Leroy Place, Socorro, NM 87801

12 Dept. of Oceanography, Dalhousie University, Halifax, N.S., B3H 4J1, Canada

${ }^{13}$ U.S. Geological Survey, Geophysics, Box 351650, Univ. of Washington, Seattle, WA 98195 


\section{CONTENTS}

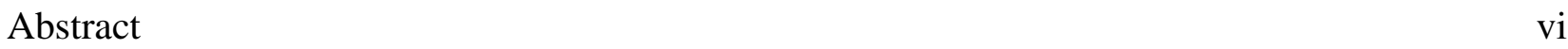

Introduction 1

Geologic Setting $\quad 2$

Data Acquisition $\quad 3$

R/V Thompson Instrumentation and Operations 3

Wide-Angle Recording $\quad 5$

Reftek Instrumentation $\quad 6$

Station Data Acquisition $\quad 9$

Station Locations and Elevations $\quad 10$

USGS OBS Deployment $\quad 12$

Dalhousie OBS Deployment $\quad 15$

Dalhousie OBS Technical Specification 16

Dalhousie OBS Deployment and Recovery 18

Processing Sequence $\quad 18$

Notes on Data Reduction $\quad 25$

Passcal Modified SEGY Trace Format $\quad 27$

Data Quality 28

Description of the Data $\quad 28$

Data Availability $\quad 30$

Acknowledgments

References Cited $\quad 33$

TABLES

Table 1. R/V Thompson Lines and Locations 36

Table 2. Expanding Spread Profile (ESP) Locations and Offsets 38

Table 3. Revised Line Numbers for Making SEGY Common Receiver Gathers 39

Table 4. List of Redefined Reftek Lines, FFIDs, Locations, and Times 40

Table 5. List of Airgun Array Ramp-up Times 42

Table 6. Origin Times, Locations, Depths, and Magnitudes of Earthquakes and

Blasts in Western Washington and Southwestern British Columbia March 7 to 25, 1998, Archived to Tape 43

Table 7. Reftek Receivers Deployed in Multiple Locations 45 


\section{APPENDICES}

Appendix 1. Abbreviated list of airgun shotpoint locations, FFID numbers, and shot times 46

Appendix 2. Reftek and OBS station locations and elevations 52

Appendix 3. List of timing used for Reftek stations 56

Appendix 4. List of stations having problems with spurious 12-second shifts 63

Appendix 5. List of location of Reftek station data on archival tapes 64

Appendix 6. PASSCAL SEGY trace header format 78 


\section{FIGURES}

Figure 1. Map of study area showing major sedimentary basins and cities 80

Figure 2. Map of study area showing locations of SHIPS seismic lines and recorders 81

Figure 3. Detail of map showing locations of SHIPS seismic lines and recorders 82

Figure 4. Map showing locations of SHIPS seismic lines and recorders in the Puget Lowland 83

Figure 5. Map showing locations of Expanding Spread Profiles (ESPs) 84

Figure 6. Common midpoint maps and receiver offsets for ESPs 1 and 2

Figure 7. Common midpoint maps and receiver offsets for ESPs 3 and $4 \quad 86$

Figure 8. Common midpoint maps and receiver offsets for ESPs 5 and $6 \quad 87$

Figure 9. Common midpoint maps and receiver offsets for ESPs 7 and $8 \quad 88$

Figure 10. Common midpoint maps and receiver offsets for ESPs 9 and $11 \quad 89$

Figure 11. Common midpoint map and receiver offsets for ESP $12 \quad 90$

Figure 12. Record section for ESP 1 in Hood Canal 91

Figure 13. Record section for ESP 2 in the eastern Strait of Juan de Fuca 92

Figure 14. Record section for ESP 3 in the western Strait of Juan de Fuca 93

Figure 15. Record section for ESP 4 in the western Strait of Juan de Fuca 94

Figure 16. Record section for ESP 5 in the southern Strait of Georgia 95

Figure 17. Record section for ESP 6 in the Strait of Georgia 96

Figure 18. Record section for ESP 7 in the Strait of Georgia 97

Figure 19. Record section for ESP 9 in Puget Sound 98

Figure 20. Record section for ESP 12 in the eastern Strait of Juan de Fuca 99

Figure 21. Record section for USGS OBS1 for Line 2 in Puget Sound 100

Figure 22. Record section for USGS OBS3 for Line 2 in Puget Sound 101

Figure 23. Record section for USGS OBS5 for Line 2 in Puget Sound 102

Figure 24. Record section for USGS OBS7 for Line 2 in Puget Sound 103

Figure 25. Record section for USGS OBS8 for Line 2 in Puget Sound 104

Figure 26. Record section for USGS OBS9 for Line 2 in Puget Sound 105

Figure 27. Record section for Canadian COBS1 for Line 6 in the Strait of Georgia 106

Figure 28. Record section for Reftek station OR06 for Line 4 in the Strait of Juan de Fuca 107

Figure 29. Record section for Reftek station OR22 for Line 4 in the Strait of Juan de Fuca 108

Figure 30. Record section for Reftek station CA04 for Line 4 in the Strait of Juan de Fuca 109 
Figure 31. Record section for Reftek station CA19 for Line 6 in the Strait of Georgia 110

Figure 32. Record section for Reftek station CA50 for Line 5 in the Strait of Georgia 111

Figure 33. Record section for Reftek station 1011 for Line 9 in Puget Sound 112

Figure 34. Record section for Reftek station 1012 for Line 9 in Puget Sound 113

Figure 35. Record section for Reftek station 1013 for Line 9 in Puget Sound 114

Figure 36. Record section for Reftek station 1014 for Line 9 in Puget Sound 115

Figure 37. Record section for Reftek station 1015 for Line 9 in Puget Sound 116

Figure 38. Record section for Reftek station 1016 for Line 9 in Puget Sound 117

Figure 39. Record section for Reftek station 1017 for Line 9 in Puget Sound 118

Figure 40. Record section for Reftek station 8003 for Line 2 in Puget Sound 119

Figure 41. Record section for Reftek station 7007 for Line 3 in Hood Canal 120

Figure 42. Reftek recordings of M2.8 earthquake 12000611.7 km WSW of Morton, Wash. 121

Figure 43. Reftek recordings of M2.3 earthquake $1200186.3 \mathrm{~km} \mathrm{SSW}$ of Seattle, Wash. 122

Figure 44. Reftek recordings of M2.1 earthquake 1200283 km ESE of Bellevue, Wash. 123 


\begin{abstract}
This report describes the acquisition and processing of deep-crustal wide-angle seismic reflection and refraction data obtained in the vicinity of Puget Lowland, the Strait of Juan de Fuca, and Georgia Strait, western Washington and southwestern British Columbia, in March 1998 during the Seismic Hazards Investigation of Puget Sound (SHIPS). As part of a larger initiative to better understand lateral variations in crustal structure along the Cascadia margin, SHIPS participants acquired $1000 \mathrm{~km}$ of deep-crustal multichannel seismic-reflection profiles and $1300 \mathrm{~km}$ of wideangle airgun shot lines in this region using the $\mathbf{R} / \mathbf{V}$ Thompson and $\mathbf{R} / \mathbf{V}$ Tully. The Tully was used to record airgun shots fired by the Thompson in two different geometries: (1) expanding spread profiles (ESPs) and (2) constant offset profiles (COPs). Prior to this reflection survey, we deployed 257 Reftek and 15 ocean-bottom seismic recorders to record the airgun signals at far offsets. All data were recorded digitally on large-capacity hard disks. Although most of these stations only recorded the vertical component of motion, 95 of these seismographs recorded signals from an oriented 3-component seismometer. By recording signals generated by the Thompson's marine air gun array, operated in two differing geometries having a total volume of 110 and 79 liters (6730 and $4838 \mathrm{cu}$. in.), respectively, the arrays of wide-angle recorders were designed to (1) image the crustal structure, particularly in the vicinity of crustal faults and Cenozoic sedimentary basins, (2) determine the geometry of the Moho, and (3) image the subducting Gorda and Juan de Fuca plates. Nearly 33,300 air gun shots were recorded along several seismic lines. In this report, we illustrate the expanding spread profiles acquired using the Thompson and Tully, describe the land and ocean-bottom recording of the air gun signals, discuss the processing of the land recorder data into common receiver gathers, and illustrate the processed wide-angle seismic data collected using the Refteks and ocean-bottom seismometers. We also describe the format and content of the archival tapes containing the SEGY-formated, common-receiver gathers for the Reftek data. Data quality is variable but SHIPS appears to have successfully obtained useful data from almost all the stations deployed to record the airgun shots. Several interesting arrivals were observed: including refractions from the sedimentary basin fill in several basins, refractions from basement rocks forming the upper crust, $\mathrm{Pg}$, refractions from the upper mantle, Pn, as well as reflections from within the crust and from the top of the upper mantle, PmP. We separately archived more than 30 local earthquakes recorded by the Reftek array during our deployment.
\end{abstract}




\section{INTRODUCTION}

In the past decade three major seismic hazards to western Washington and British Columbia have been recognized. Large (M 9) magnitude earthquakes along the Cascadia subduction zone megathrust have been proposed and documented in the geological record (Heaton and Kanamori, 1984; Atwater, 1987; Heaton and Hartzell, 1987; Hyndman et al., 1990; Hyndman and Wang, 1993; Atwater, 1996; Atwater and Hempill-Haley, 1997). Earthquakes within the subducting Juan de Fuca plate have been observed since 1940 and thus also represent known seismic hazards (Weaver and Baker, 1988). Finally, the existence of crustal faults capable of large (M 7) magnitude earthquakes within Puget Lowlands has been inferred and mapped using a variety of methods including paleoseismicity, seismicity, seismic reflection, and potential field geophysical data (Atwater and Moore, 1992; Bucknam et al., 1992; Johnson et al., 1994, 1996; Pratt et al., 1997; Wells et al., 1998; Blakely et al., in press; Weaver et al., in press).

A number of important regional seismic reflection and refraction studies have been conducted in western Washington and British Columbia. The subducting Juan de Fuca plate has been imaged beneath Vancouver Island in a number of studies (Clowes et al., 1987a, 1987b, 1995; Calvert, 1996). Onshore offshore studies on the margin of western Washington also image the subducting Juan de Fuca slab, and the geometry of the boundary between the accretionary wedge in the Olympic Mountains and the Siletz volcanics (Luetgert et al., 1992; Flueh et al., 1997; Parsons et al., 1998, in press). Other studies have examined the crustal structure in the foothills of the Cascades (Miller et al., 1997; Symons and Crosson, 1997).

In March 1998 we conducted a multi-institutional, binational seismic investigation of the crustal structure along the western margin of North America in the Puget Sound, Strait of Juan de Fuca, and the Strait of Georgia (Fisher et al., 1999). We recorded more than 33,000 airgun shots using 257 temporary seismic stations (land-based Refteks and ocean-bottom seismometers) at offsets exceeding $370 \mathrm{~km}$. The purpose of the investigation was to obtain new, three-dimensional structural control on the seismogenic structures and Cenozoic basins in western Washington and 
southwestern British Columbia. A primary goal of this experiment was to provide compressional and shear wave velocity information for the sedimentary basin fill of the Tacoma, Seattle, and Everett Basins and the Fraser River delta to allow better forecasts of earthquake shaking effects in these urban areas (Figure 1). The new 3-D models developed from these data will be used to calculate synthetic seismograms to help understand the lateral variations of strong ground motions in the Puget Lowland urban corridor.

\section{Geologic Setting}

Recent interpretation of seismic reflection data and gravity data by Pratt et al. (1997) have led to the recognition of ramp-and-flat structures developed along north-vergent thrust faults. The Tacoma, Seattle, and Everett basins form a series of east-west oriented structural lows associated with the thrust faults (Johnson et al., 1994): Pratt et al. (1997) proposed that on the basis of the ramp-and-flat structures that a north vergent thrust sheet underlies Puget Sound. Existing seismic reflection data did not image the thrust faults beneath the sediment fill-bedrock contact. The observation that these basins coincide with the locations of Quaternary depocenters (Jones, 1994) suggests that the thrust faults remain active (Pratt et al., 1997).

Existing tomographic models for the Puget Lowland were hampered by the low number of seismic stations and relative sparsity of shallow earthquakes (Symons and Crosson, 1997). SHIPS was conducted with the understanding that an improved image of the seismic velocity structure of the crust can result only from additional seismic reflection and refraction profiling in Puget Sound. Existing hydrocarbon test wells do not provide an adequate knowledge of the geometry of the large basins in Puget Lowlands (Johnson, 1993; Johnson et al., 1993; Brocher and Ruebel, 1998).

The Seismic Hazards Investigation of Puget Sound (SHIPS) was conducted in March 1998 to address the need for an improved knowledge of the regional crustal structure in western Washington and southwestern British Columbia. 


\section{DATA ACQUISITION}

\section{$\underline{\mathbf{R} / \mathbf{V} \text { Thompson Instrumentation and Operations }}$}

Using the R/V Thompson, SHIPS participants acquired several wide-angle seismic lines as well as deep-crustal seismic-reflection profiles in Puget Sound, Strait of Juan de Fuca, and Strait of Georgia (Figures 2 to 4, Tables 1 to 3, Appendix 1). For the first several days of the experiment, Julian Day (JD) 069 to JD 077 (March 10th to 17th), the Thompson fired its airgun array 12,963 times without recording the signals on a seismic streamer. These airgun shots were intended solely to be recorded by the wide-angle seismic array described below, as well as by seismic stations in the permanent earthquake monitoring arrays in Washington and British Columbia. Airgun shots were fired at 40 second intervals in order to minimize shot generated noise and to allow the air compressors to recharge the airgun array. By not deploying the streamer for this part of the survey the Thompson was able (1) to deploy a larger airgun array consisting of 16 individual airguns (totaling 110.3 liters $(6730 \mathrm{cu}$. in.)), and was also able (2) to survey in constricted waterways such as Hood Canal in which it would have been impossible with the 2.4-km-long multichannel seismic streamer deployed.

The ship started its wide-angle work in Lake Washington (Thompson Line LW1) on JD 069 (March 10th), then crossed into the Puget Sound where it first steamed south then north (Thompson Lines 2-4), and then westward into Hood Canal (Figure 4, Table 3). After completing southward and northward directed transects in Hood Canal on JD 073 (March 13th), the Thompson sailed westward in the Strait of Juan de Fuca. After nearly reaching Cape Flattery, the ship turned and returned to the eastern Strait of Juan de Fuca on JD 075 (March 15th), whereupon it sailed northwestward up the Strait of Georgia as far north as Texada Island (Figure 2).

Following completion of the wide-angle shooting on JD 077 (March 17th), the Thompson deployed a seismic streamer at the northern end of the survey near Texada Island on JD 078 (Figure 2). Deployment of the 2.4-km-long, 96-channel digital seismic streamer reduced the number of airguns which could be towed by three, yielding a smaller, 13 airgun array with a total airgun volume of 79.3 liters (4838 cu. in.). After deploying the multichannel streamer, the Thompson 
sailed southeastward through the Strait of Georgia collecting Thompson Line SG1 (Table 1), profiled past the San Juan Islands, and sailed westward into the Strait of Juan de Fuca to acquire Thompson Line JDF1. After turning eastward on JD 079 to acquire Line JDF2 the Thompson returned to the eastern Strait of Juan de Fuca where she sailed southward into Puget Sound to acquire Line PS1, crossing the Seattle fault (Table 1). After reaching Tacoma, the ship turned back northward acquiring Line PS2, and returned to the eastern Strait of Juan de Fuca, where it finished the survey on JD 083 (March 23rd) after completing a series of short seismic reflection lines across suspected fault zones (Thompson Lines JDF 3 to 6). During the reflection profiling the near-trace of the seismic streamer was $200 \mathrm{~m}$ behind the ship, the group interval was $25 \mathrm{~m}$, and the far trace of the streamer was $2575 \mathrm{~m}$ behind the ship. The record length for the reflection data was $16 \mathrm{~s}$.

Using two short (300-m) single-channel streamers towed by the $\mathbf{R} / \mathbf{V}$ Tully to record airgun signals from the Thompson, 12 expanding spread profiles were acquired along the SHIPS track lines [Chopra et al., 1998; Fisher et al., 1998, 1999]. The expanding spread profiles (ESPs) were acquired as the two ships sailed apart from each other in opposite directions at the same speed, maintaining a common midpoint. Locations of the ESPs acquired using this method are shown in Figure 5 and given in Table 2. The streamers towed by the Tully were also used in a commonoffset mode, being towed at the same distance behind the Thompson to effectively lengthen the recording aperture of the Thompson's streamer. Figures 6 to 11 provide maps showing the locations of common-midpoint locations and source-receiver offsets versus shot numbers for the 12 ESPs acquired during SHIPS. These figures show the spread of common-midpoints for each ESP. Figures 12 to 20 show the waveforms of the ESPs acquired during SHIPS.

Air gun firing times on the Thompson were determined from the air gun fire command time as measured on a Global Positioning System (GPS) clock. Origin times of the air gun array are believed to be accurate to within a millisecond. Navigation of the Thompson was also achieved using a GPS receiver; these coordinates are estimated to be accurate to within $40 \mathrm{~m}$. The air gun array, composed of Bolt air guns, was generally towed at depths between 8 and 10 meters. The 
airgun shot locations represent locations for the midpoint of the airgun array having been corrected for the offset between the GPS antenna and the airgun array.

Table 1 provides the locations and time for the start and end of the 14 SHIPS lines recorded on the R/V Thompson. During our processing of the wide-angle Reftek data into commonreceiver gathers we rearranged and reduced the number of airgun shotlines into 11 slightly different seismic lines (Table 3). Table 3 indicates how the airgun shots labeled on the Thompson were divided into the new 11 lines. Lines 1, 6, 7, and 8 are the same in both schemes.

In addition to modifying the seismic line numbers we have renumbered the airgun shot Field File Identification Numbers (FFIDs) as well. This renumbering of the airgun shot FFIDs was necessary so that each airgun shot has an unique FFID. Table 4 shows the new FFIDs used for the new lines: shots along each new line have a different unit of 10,000 added to the FFID (line number times 10,000). Appendix 1 provides a table identifying the correspondence between the FFIDs used on the Thompson and those used within this report for the wide-angle gathers. Appendix 1 also provides an abbreviated list of the airgun shotpoint locations and times, with information given for shots acquired at 30-minute intervals.

To avoid injury to marine mammals the air gun array was turned off when marine mammals were observed to be within a specified radius of the Thompson's airguns. Table 5 provides a list of times when the airgun array was turned off for this and other reasons. After shutting off the airgun array, the airgun volume was built up slowly, over a period of 30 minutes, in order not to inadvertently damage the hearing of any nearby marine mammals. Thus, the quality of airgun signals at wide-angles of incidence could be adversely affected during these airgun "ramp-ups". Table 5 also provides the Reftek FFIDs corresponding to the start of these "ramp-ups", as well as the line number and FFID used on the Thompson.

\section{Wide-Angle Recording}

The signals generated by the air gun array towed by the Thompson were recorded in a wide-angle geometry using 257 Reftek recorders. Many of the Refteks were deployed along the 
ships tracks to provide quasi two-dimensional lines; typically the curvature of the waterways precluded purely linear profiles. Many Refteks were also deployed well off-line to provide better three-dimensional coverage of the survey area. Most of recorders were deployed in the Puget Lowland, along the Strait of Juan de Fuca, and along the Strait of Georgia (Figures 2 to 4). Air gun signals were recorded at ranges as close as $1 \mathrm{~km}$ and as far as $370 \mathrm{~km}$. Appendix 2 presents the location and elevation of each Reftek station.

The digital Reftek recorders deployed consisted of five major components (PASSCAL, 1991). These components include the (1) Data Acquisition System (DAS), (2) internal or external hard disk drive, (3) internal oscillator and, in most cases, internal or external GPS Clock, (4) 3component seismometer, and (5) external batteries. For continuous recording for the 18-day length of recording, it was necessary to supplement the small internal Reftek battery with one or two 12-V external (car) batteries. Each Reftek DAS was monitored in the field using either a Palm-Top HP Terminal (Palm-Top) or a Hand Held Terminal (HHT). The Palm-Top Terminals were used to program the DAS of each Reftek prior to their deployment, determining such parameters as the sample rate $(100 \mathrm{~Hz}$ in our case), mode of recording (continuous in our case), and number of channels to record ( 1 or 3 ). The GPS receiver clocks had a duty cycle of 5 minutes per hour. Recording was simply halted when the instrument was retrieved after the end of shooting.

\section{$\underline{\text { Reftek Instrumentation }}$}

Our need for a large number of recorders (257) required us to use all available IRIS/PASSCAL Refteks, of which there were 4 different models (Reftek 06's, 07's, 07G's, and 08's). Given the large variety of data storage (hard disk) capacity and clock capabilities between these models, we briefly describe how each model was deployed during SHIPS.

The Reftek 06's were 3-channel recorders with external GPS receiver and antennas, and had relatively small 230 Mbyte internal hard disk drives. For this reason they were programmed to record a single (vertical) component. The relatively small hard drive also required that these

models be downloaded at least once during the field experiment. Reftek 06's lacking an external 
GPS receiver needed to be manually pulsed every 2 days. DAS serial numbers for Reftek 06's had four digits that started with a 6.

The Reftek 07's were 3-channel recorders with either internal or external GPS receivers and antennas, and had a variety of internal hard disk drives of 230, 500, and 540 Mbytes in size. Regardless of the hard drive size, this model was programmed to record a single (vertical) component. Those with 230 Mbyte disk drives also needed to be field downloaded at least once. Those Reftek 07's lacking external GPS receiver needed to be manually pulsed every 2 days. DAS serial numbers for Reftek 07's had four digits that started with a 7.

The Reftek 07G's were 3-channel recorders having internal GPS receivers and antennas. All of these models had 1 Gbyte internal hard disk drives, and thus could be programmed to record 3component data without needing to be downloaded in the field during the experiment.

Finally, the Reftek 08's are 6-channel recorders having external GPS receivers and antennas. This model generally had 1 Gbyte external hard disk drives, and thus was programmed to record 3components (channels 4-6) without the need for downloading data in the field. Reftek 08's had three digit DAS serial numbers (e.g., 449).

Nearly all of the geophone sensors used during SHIPS consisted of Mark Products model L28s, which were $4.5 \mathrm{~Hz}, 3$-component seismometers. At 20 stations we deployed Mark Products model L-22 sensors, which were $2 \mathrm{~Hz}$, 3-component seismometers requiring careful leveling when they are installed. The L-22 sensors were deployed at stations shown as triangles in Figures 3 and 4. The sensors at all stations that recorded 3-component data were oriented with compasses such that the N-S component was directed to magnetic north. Stations at which all three geophonecomponents were recorded are indicated in Appendix 2 and on Figures 2 to 4 . Channels 1 or 4 were used for the vertical component, channels 2 and 5 were used for the N-S oriented horizontal components, and channels 3 and 6 were used for the E-W oriented horizontal components.

The power requirements of the Refteks generally required us to deploy two 12-V, 80Amp/Hr car batteries connected in parallel at each site. Reftek model 06's without GPS receivers with lower power requirements were deployed with only one battery. In the US, the car batteries 
were swapped midway through the deployment over a four day period from JD 073 to JD 076 (March 14-17). Each day approximately 50 batteries were replaced by fresh batteries and the 50 depleted batteries were charged overnight and used to replace the next set of 50 batteries the following day. For the 43 units deployed in Canada, brand-new batteries were rented. Fully charged just before deployment, all batteries lasted the full length of the experiment without recharging.

The Hand Held Terminal (HHT)/HP Palm Top Programmers used in the field were programmed by PASSCAL personnel to run a program called Magic. Magic allows only certain options of the Field Set-up Controller (FSC) program to be run, but is more robust to operator error. One drawback of both the HHTs and Palm Top Terminals is that they fail when wet. In an effort to help keep these field programmers dry, golf umbrellas were distributed to each deployment team.

For Refteks 06's and 07's lacking internal or external GPS clocks, it was necessary to manually pulse time into the Reftek every few days. This pulsing was performed using Master Clocks (which are external GPS clocks), and the Palm Top Terminals.

A new model of Field Fast Data Transfer Units were used for the first time during SHIPS. These functioned reasonably well and field downloading did not add appreciable amounts of time to station visits. To download data in the field, one first pulses time onto the DAS with the master clock. Then one stops data acquisition by the DAS using either Magic or FSC commands. Next, the internal Reftek drive is forced to spin up using commands in FSC (F-5, 4-SCS Power, 1-Set SCSI Pwr On). The SCSI cables are then connected between the Reftek DAS and the Fast Field Data Copy System. Next, power up the Fast Field Data Copy System by connecting its power cable either to a Reftek power port or to a battery. After a couple of minutes the LED screen on the Fast Field Data Copy System will indicate how much disk space is available and asks whether one wants to start the fast copy procedure. After completing the data transfer one disconnects power to the Fast Field Data Copy System and disconnects the SCSI cables to the Reftek DAS. The final step is to reformat the Reftek DASs internal disk to allow more data to be recorded by that station using FSC commands. 
As protection from the elements, the equipment was deployed in firm plastic enclosures (Action Packers) at each station to help keep the Reftek DASs, GPS antennas, and batteries dry. The Reftek 08 units did not fit within standard size of enclosures, however, and required the GPS antenna or batteries be deployed outside of the plastic enclosure.

\section{Station Data Acquisition}

All Refteks were programmed to record the following parameters: (1) continuous recording with a sample rate of $100 \mathrm{~Hz}$, (2) recording to start at the time of deployment, (3) recording to be halted at the time of retrieval, and (4) the continuously recorded data were divided into 30-minutelong events in the USA (and into 60-minute-long events in Canada). As described earlier, the different Reftek models each had their own program: (1) 06-con (continuous recording of Reftek 06's), (2) 07_con (continuous recording of 07's), (3) 07G540-c (continuous recording of Reftek 07's having 540 Mbyte drives), (4) 07G1_con (continuous recording of Reftek 07G's having 1 Gbyte drives), (5) 08_con (continuous recording of Reftek 08's).

Almost all Reftek recorders were deployed over a four-day period from JD 066 to JD 069 (March 7 to 10th). In the USA the number of Reftek DASs was sufficient so as to not require moving DASs between stations, DASs which failed were replaced by spares. Thus, at 11 USA sites there were more than one DAS unit deployed at a single site (Stations 1007, 1009, 2004, 2012, 4004, 4006, 6010, 7006, 7012, 9012, 9030; Appendix 2). Therefore, the records obtained by the two (or in some cases more than two) DASs at a station needed to be processed to sample all the SHIPS lines. In the USA, only the DAS (\#7466) along the Strait of Juan de Fuca at station OR12 (9012) was moved westward to station OR26 (9026) near Cape Flattery (Figure 2).

There were not, however, sufficient DASs available to the Canadian participants to allow them to simultaneously occupy all the desired sites. For this reason, 12 DASs were used to obtain wide-angle data at 21 stations (Table 7). Almost all of the stations along the eastern side of the Georgia Strait (Stations 11030-11033 and 11043-11053) remained at the same station for the entire SHIPS experiment. Of the Canadian DASs that were moved (Table 7), those on southern 
Vancouver Island (Figure 2), including Stations 11001-11002 recorded Lines 3-5 only, Station 11003 recorded only Lines 3 to 11, and Stations 11010-11011 and 11013 recorded Lines 4 and 5

only. Along the west side of Georgia Strait, Station 11023 recorded only Lines 1 to 3, and Stations 11024-11029 recorded all lines except Line 4. On the deployment across the Coast Belt (Figure 2), Stations 11033-11037 recorded only Lines 1 to 5, and Lines 11038-11042 recorded Lines 6 to 11. In some cases more than one DAS was used to record data at a station (Table 7), although no DASs recorded data at the same station simultaneously. This mode of operation introduced considerable complexity into the processing flow for these DASs as described below.

The first airgun shots were fired in Lake Washington at 1924 Universal Time (UTC) on JD 069 (March 10th). The last airgun shot was fired in the eastern Strait of Juan de Fuca at 0345 UTC on JD 083 (March 24th). Retrieval of the Refteks started on JD 083 (March 24th) and ended JD 085 (March 26th). The Refteks that had been deployed in the USA and in Canada were separately shipped back to the PASSCAL Instrument Center at Palo Alto.

\section{$\underline{\text { Station Locations and Elevations }}$}

Wide-angle recorders were deployed by teams from the U.S. Geological Survey and the University of Texas El Paso (stations 1001-8014), by Oregon State University (stations 9001-9031 [also referred to as OR01-OR31], there being no station 9020 [OR20]), by the University of Washington (stations 10001-10060 [also referred to as UW01-UW60]), and by several Canadian groups (stations 11001-11053 [also referred to as CA01-CA53]) (Figure 2, Appendix 2). Each team was responsible for deploying and maintaining between 10 and 14 stations. For stations 1001-8014 the station numbers generally increase to the south and to the west, for stations OR01-OR31 (90019031) the station numbers increase to the west, for stations 10001-10060 the station numbers increase to the south and east, and for stations 11001-11053 the station numbers increase to the north (Figure 2). The locations of the 9 USGS ocean-bottom seismometers (UOBS1-UOBS9), 6 Canadian ocean-bottom seismometers (COBS1-COBS6), and 13 strong-motion stations deployed in West Seattle by the USGS/Golden are provided at the end of Appendix 2. The data from these 13 
strong-motion stations, which consisted of DR200, K2, and Reftek seismic recorders, are not described here.

Almost all Reftek stations had built-in or auxiliary GPS receivers which provided estimates of the station latitude, longitude, and elevation (Appendix 2). Thus the coordinates in Appendix 2 generally represent the average GPS location for the 17 days of GPS data recorded once an hour (providing 408 separate measurements). Estimated average uncertainties (1 standard deviation from the average location) of the latitudes and longitudes are about $50 \mathrm{~m}$. Station elevations for the USA stations (1001 to 10060) were determined from a digital version of USGS topographic maps using GPS coordinates for the latitude and longitude. The agreement was generally within 20 meters: we observed a bias of $18 \mathrm{~m}$ caused by differences between the GPS and the USGS datums. Although this difference is small, we used the elevations provided by USGS topographic maps as the station elevation (these are the elevations written in the trace headers). As an additional check on the accuracy of the Reftek GPS locations, the Reftek locations for stations 10001-10060 were checked against preliminary GPS locations made at these stations made using a portable GPS receiver. Because the actual Reftek location sometimes differed from these preliminary sites, the median difference of 119 meters suggests that the Reftek GPS latitudes and longitudes are sufficiently accurate for wide-angle studies.

Only 25 USGS and Oregon State University stations either lacked a GPS receiver or did not obtain a GPS lock and thus provided no GPS coordinates. For these stations the locations and elevations were picked from digital USGS 7 1/2 minute topographic maps on CD-Rom. These stations are indicated on Table 3.

The station coordinates and elevations for the Canadian stations (11001-11053) were determined slightly differently. These coordinates, deemed informally as not-quite differential GPS, relied on single-site GPS, with corrections using precise clocks and orbits. The latitudes and longitudes were checked against those determined using the internal or auxiliary GPS receivers (the median difference of the two different GPS measurements was $43 \mathrm{~m}$ ). All the elevations for the Canadian stations were determined from not-quite differential GPS measurements. The reference 
datum used was NA83 (this is almost the same datum as the WGS84 datum used by the GPS units in the Refteks). The original GPS elevation (ellipsoidal height) was corrected to height above sea level by subtracting the geoid height. Geoid heights for our area, determined from a commercial program, varied mainly with latitude, and so corrections were applied assuming the following geoid heights:

$\begin{array}{cc}\begin{array}{cc}\text { Latitude Range } \\ <49.25\end{array} & -17( \pm 2) \mathrm{m} \\ 49.25-49.75 & -16.6( \pm 0.4) \mathrm{m} \\ 49.75-50.25 & -14.8( \pm 0.5) \mathrm{m} \\ 50.25-50.75 & -13.4( \pm 0.2) \mathrm{m} \\ >50.75 & -11.8( \pm 0.3) \mathrm{m}\end{array}$

The quoted height error is just the approximate variation in height along the given line of latitude in our area, and should really be added to the RMS-elevation values in Appendix 2. The median difference between these elevations and those provided by the GPS units within the Refteks themselves is $-19 \mathrm{~m}$, close to the correction applied from the above table.

Very few (about 3) of the Reftek stations were vandalized and none were stolen. The station at 4013 was vandalized and the geophone cable was severed.

\section{USGS OBS Deployment}

To simplify the field logistics, the 9 USGS OBSs (UOBS1 to UOBS9) were deployed only once in Puget Sound, and thus each were used to record at a single site (Figure 4). All USGS OBSs were placed on fine sand and muddy sand bottoms at least $1.5 \mathrm{~km}$ from the nearest ferry route or anchoring area and in waters which are believed to have tidal currents of generally less than 0.5 knots. These criteria for selecting OBS locations were used to increase OBS coupling to the seafloor 
and to reduce water column noise. OBS anchors were fashioned from a perforated flat metal plate 1.02 meters (40") in diameter and weighing $45.4 \mathrm{kgs}$ (100 lbs.).

OBS locations were determined using differential GPS navigation and are believed to be accurate to within 1-2 meters. Depths were determined using available bathymetric maps and are believed to be accurate to within 10 meters. The USGS OBS locations and water depths are provided in Appendix 2.

The OBSs were deployed and retrieved using the SP Stanley Hayes, a $12 \mathrm{~m}$ vessel owned and operated by NOAA-PMEL in Seattle. Personnel on the Hayes included Gregory Speer (skipper, NOAA-PMEL), Uri ten Brink (scientist, USGS-Woods Hole), Gregory Miller (OBS engineer, USGS-Woods Hole), Michael Taylor (deck hand, USGS-Woods Hole), and Alvin Buchholtz (deck hand, volunteer). The OBSs were deployed with three relocation aides: Strobe, VHF Radio beacon, and acoustic transponder. The OBSs were acoustically released, and have ranging capabilities.

The USGS OBSs were deployed on JD 065 (March 6th) and were programmed to start recording continuous data at 2000 UTC on JD 067 (March 8th). Recording by the OBSs ended upon recovery of the OBSs on JD 084 (March 25th). The OBSs digitally recorded data at 100 samples/second. All the OBSs were equipped with Seascan clocks with accuracy of $1 \times 10^{-8} \mathrm{sec}^{-1}$ or a drift of $\sim 1$ msec per day. A linear drift rate was assumed for the duration of the experiment and times were corrected accordingly. Four channels were recorded by the OBSs, including three from a gimbaled, 3-component 4.5 Hz L15B seismometer and one from an OAS E-2S hydrophone. 
Two of the USGS OBSs failed upon deployment and two others failed midway through the experiments. OBS7 (A8) failed after writing 680 tracks (226 hours, 9.4 days) due to a disk write failure. OBS4 (C4) failed after writing 170 tracks (56 hours, 2.3 days) due to disk write failure. Data on both were recovered and are usable until the time of OBS failure. OBS6 (D4) did not record valid data due to a failure of the power supply to the sensors at the time of deployment. OBS2 (A3) did not record valid data due to a bad voltage regulator.

Additional specifications about the USGS OBSs are provided in the following tables.

\section{USGS OBS Specifications}

\begin{tabular}{|c|c|c|c|}
\hline Dimensions (meters): & Width & Height & Weight in air (kgs): \\
\hline on deployment & $1.02(40 ")$ & $0.97(38 ")$ & 170 (375 lbs.) \\
\hline on recovery & 0.69 (27") & $0.97(38 ")$ & 125 (275 lbs.) \\
\hline $\begin{array}{l}\text { Dynamic range } \\
\text { each data point. }\end{array}$ & ordin & tem: $72 \mathrm{~d}$ & nverter $)+30 \mathrm{~dB}$ (1-step gain range) for \\
\hline
\end{tabular}

Data format: Binary with header information for each 1 Megabyte of data

USGS OBS Deployment and Recovery Times (Universal time)

\begin{tabular}{|c|c|c|}
\hline OBS & $\begin{array}{l}\text { Time of } \\
\text { Deployment } \\
\text { on JD } 065 \\
\text { (March 6) }\end{array}$ & $\begin{array}{l}\text { Time of } \\
\text { Recovery } \\
\text { on JD 084 } \\
\text { (March 25) }\end{array}$ \\
\hline No. & $\underline{\text { Hr:Min }}$ & Hr:Min \\
\hline A4 & $17: 46$ & $17: 21$ \\
\hline $\mathrm{C} 1$ & $18: 35$ & 18:04 \\
\hline
\end{tabular}




$\begin{array}{lll}\text { A8 } & 19: 07 & 18: 37 \\ \text { D4 } & 19: 48 & 19: 16 \\ \text { D1 } & 20: 58 & 19: 58 \\ \text { C4 } & 21: 34 & 23: 30 \\ \text { A1 } & 22: 15 & 22: 56 \\ \text { A3 } & 22: 42 & 22: 29 \\ \text { C9 } & 23: 19 & 21: 23\end{array}$

The USGS OBS data were converted to SEGY format after retrieval of the OBSs. The FFIDs written to the trace headers of these gathers are for the shot FFIDs used on the Thompson, and are not those assigned here to the Reftek data. Record sections from the six successful USGS OBS deployments are shown in Figures 21 to 26.

\section{Dalhousie OBS Deployment}

The six Dalhousie University OBSs (COBS1 to COBS2) were deployed in Georgia Strait from the CGS Vector on JD 066-067 (March 7-8), by Keith Louden and Bob Iuliucci (Figure 2). Like the USGS OBSs, these OBSs recorded signals from 3 orthogonal geophone components and one hydrophone (see technical specifications below). Coordinates and water depths of the Dalhousie OBSs are provided in Appendix 2. The programmed recording durations were 9 days, starting on 08:00 UTC on JD 073 (March 14th). All 6 OBSs were successfully recovered using the CCGS Tully (see table of deployment and recovery times below). However, one OBS (COBS6) failed to record data due to a fault in the cable to the hard disk and one (COBS5) stopped recording before the programmed end time for unknown reasons. Thus, five of the Dalhousie OBSs provided 
useful data. An example of these OBS data is shown in Figure 27, showing data from COBS1

recorded during Line 6 in the Strait of Georgia. This record section has been plotted with an

automatic gain control of 2 seconds in duration. The FFIDs written to the trace headers of these

gathers are for the shot FFIDs used on the Thompson, and are not those assigned here to the Reftek

data.

Dalhousie OBS Technical Specification

Item

Housing/Platform

Release

Duration of recording

Sampling rates/

dynamic range

Anti-alias filter

Gain

Max electrical noise

Clock

Data storage

Sensors

External connectors
Specification

Uses existing design of BIO-OBS (6 km maximum water depth).

Weight in air: instrument $(82 \mathrm{~kg})$; anchor $(55 \mathrm{~kg})$

Size: $1.1 \mathrm{~m}$ high, $1.2 \mathrm{~m}$ long, $0.6 \mathrm{~m}$ wide

$12.5 \mathrm{kHz}$ Acoustic command and timed backup

9 days @ 5.7 msec sampling of 4 channels (16 bit)

2 days @ 0.8 msec sampling of 4 channels (12 bit)

23/11.5/5.7/2.9/1.4 msec @ 16 bit (AD7716 Sigma-Delta

$\mathrm{ADC})$

1.6/0.8/0.4/0.2 msec @ 12 bit (Tattletale 7 ADC)

Switched-capacitor, software selectable with corner freqs of $12.5,25,50,100,200,500,1000 \mathrm{~Hz}$

Fixed settings hardware selectable geophones (69-93 dB); hydrophone (46-70 dB)

$<125 \mathrm{nVrms}$ on geophone input

$<1 \mathrm{uVrms}$ on hydrophone input

Austron 1115 OCXO $5 \mathrm{MHz}$ (drift<1 msec/day)

$2 \mathrm{Mb}$ RAM stored as separate files on 1 GB Toshiba HD

3-component geophone package (oil filled):

4.5 Hz (Mark L-15B or L-28; $380 \mathrm{Ohm}$ coil with 0.7 damping)

$100 \mathrm{~Hz}$ (Oyo GS-100; 975 Ohm coil with 0.7 damping)

hydrophone (OAS E-2SD)

4-pin (RS-232 communication and time pulse)

3x1-pin (hydrophone and release) 
Batteries

Recovery Aids
D-cell alkaline (clock), lifetime $>21$ days

D-cell alkaline (analog and digital and data logger)

acoustic release 9-volt alkaline (electronics)

9-volt alkaline (pinger and release)

TT7 parallel interface to AT-DIO-24 (100 kbyte/s)

Strobe and radio beacon (Novatech ST400A, RF700A-1)

$12.5 \mathrm{kHz}$ pinger (ITC 3013 transducer) 
Dalhousie OBS Deployment and Recovery

$\begin{array}{lrrrrr}\text { Station } & \text { OBS ID } & \begin{array}{c}\text { CCGS Vector } \\ \text { Deployment } \\ \text { Time (UTC) }\end{array} & \begin{array}{c}\text { CCGS Tully } \\ \text { Recovery } \\ \text { Time (UTC) }\end{array} & \begin{array}{c}\text { Recording } \\ \text { Start Time } \\ \text { (UTC) }\end{array} & \begin{array}{c}\text { Recording } \\ \text { Stop Time } \\ \text { (UTC) }\end{array} \\ \text { COBS1 } & \text { A } & 3 / 7 / 982035 & 3 / 24 / 982300 & 3 / 14 / 980800 & 3 / 22 / 982255 \\ \text { COBS2 } & \text { C } & 2206 & 2148 & 3 / 14 / 980800 & 3 / 22 / 982255 \\ \text { COBS3 } & \text { B } & 2306 & 2030 & 3 / 14 / 980800 & 3 / 22 / 981043 \\ \text { COBS4 } & \text { D } & 3 / 8 / 980006 & 1910 & 3 / 14 / 980800 & 3 / 22 / 982255 \\ \text { COBS5 } & \text { E } & 0111 & 1705 & 3 / 14 / 980800 & 3 / 17 / 981814 \\ \text { COBS6 } & \text { F } & 0245 & 1605 & \text { No Recording } & \end{array}$

\section{REFTEK DATA REDUCTION}

Processing Sequence:

In the following discussion, the names of software programs, scripts, and shells are highlighted in bold.

1) DASs that failed in the field and those DASs with small internal disk drives ( $<230$ Mbytes) (for Stations 1001 to 9031) were downloaded in rawrefdump format at the Kitsap County Fairground field headquarters at Silverdale, Washington. These rawrefdump-formatted files were converted into SEGY format using ref2segy, were stored on disk, and archived onto multiple DLT tapes.

2) The remaining DASs (stations 1001 to 9031,10001 to 10060,11001 to 11054 ) were trucked back to the PASSCAL Instrument Center at Stanford University between March 26th and 27th.

3) At the PASSCAL Instrument Center at Stanford University, these latter Refteks were downloaded using a special shell created for SHIPS called download.sh. This script 
downloaded the data from the Refteks and wrote the data in rawrefdump format to several 20Gbyte disks. In addition, the download.sh shell wrote the rawrefdump data to archival DLT and DAT tapes. Files created during this process are named Station\#.DAS serial \#.Channels.Day1:Day2, where Day1 is the first Julian Day with acquisition, and where Day2 is the end day of acquisition [e.g., B2012.0149.456.068:083]. Logfiles for each downloaded Reftek were generated using the ref2log utility. Prior to running the download.sh, it was necessary to (1) connect power to the Reftek DAS unit to cause the internal disk to spin up, and then for some DAS models, to (2) use FSC on a Palm Top Programmer to force the internal disk to spin up (F5, 4-SCSI Power, 1-SCSI Power On), and then (3) to connect the SCSI cable to the Reftek DAS. The order in which these three steps are performed is important. Typically, the volume of data downloaded at this stage varied from about 100 Mbytes for one-component stations that had been downloaded in the field to 1000 Mbytes for a 3-component station that had not been downloaded in the field. Altogether, nearly 100 Gbytes of rawrefdump-formatted data were acquired during SHIPS.

Several DASs could not be fully downloaded due either to hard disk problems or disk initialization problems. After repair of the disks, data for stations 1011, 1016, 9007, 9008, 9015, 9028, 9030, 10001, 10011, and 10049 could be fully downloaded minus a nearly insignificant loss of data. Data from station 1010, however, could not be read back after JD 077.

Downloading of the SHIPS data at PASSCAL Instrument Center was started using 3 separate workstations on April 1st, 1998 and was completed April 20th, 1998.

4) The logfiles generated at the Kitsap County Fairground field headquarters and at the PASSCAL Instrument Center at Stanford University were collected into a single directory. 
5) GPS locks recorded in the logfiles for each station were then averaged to provide GPS estimates of the station location and elevation using the program position. Stations for which no GPS location was provided (due to the absence or failure of the GPS receiver), are indicated on Appendix 2.

6) A file containing the station number, DAS number, the station longitude, latitude and elevation was compiled. Refteks that had been moved between stations were noted (Table 7). A set of receiver files was generated that noted when the Refteks were moved. If a Reftek was moved between stations during the acquisition of a seismic line, the shell then generated a separate common receiver gather for each location for that seismic line. Thus, some of these stations have 12 or 13 lines instead of the nominal 11 lines.

7) A script was written (by B.C. Beaudoin) to look for possible clock timing errors in the Reftek logfiles. Flags were set if the number of GPS locks for a Reftek DAS was less than 20, corresponding, on average, to less than one GPS lock per day. In this case, the script then looked for pulses manually pulsed into the Reftek memory during the deployment. If the number of manual pulses was less than 4 , corresponding to one pulse every 4 days, then the Reftek was flagged as having potential timing errors. If the number of pulses was greater than 4 , then in subsequent processing the timing correction program refrate was automatically called. Flags were also raised if the first GPS lock (or pulse) was not on the deployment day or is the last GPS lock (or pulse) was not on the retrieval day. At some stations, the Reftek DAS clock timing is based on both GPS and manual pulses. 
During subsequent processing, we visually inspected the clocks in every logfile using clockview. Clocks which had more than 20 GPS locks but which lost lock for significant intervals, usually longer than a day, were noted and if the internal clock drift was in excess of $20 \mathrm{msec}$, refrate was run manually. Appendix 3 provides, for each station, a list of whether the clock timing used for the station was based on GPS locks or manual pulses or both, and whether refrate was run for the station. The reason why refrate was run is also usually given. This appendix also provides a brief description of the quality of the GPS locks (amount of clock drift between time jerks), the quality and quantity of manual pulses, and any other timing (e.g., GPS failure, too few manual pulses) or data acquisition problems noticed for each station during processing.

8) The locations of the rawrefdump-formatted and SEGY-formatted data on all the various hard disks were tabulated in a look-up table.

9) As previously described the $>33,000$ airgun shots were divided into 11 shot lines based on the locations of the ship. This list of airgun shots is given in Table 4 and Appendix 1.

10) The source-receiver range in integer meters for each airgun shot and every station were calculated and placed in separate files for every DAS and each of the 11 shot lines (by T. Parsons).

11) An interactive shell was written and tested by B.C. Beaudoin and M.G. Alvarez to generate common-receiver, SEGY-formatted, gathers from the rawrefdump-formatted data. Although this shell, named SegyGather.csh, could not be fully automated it attempted to maximize the 
automation of the data processing. In this shell all processing was referenced to the Reftek DAS serial number. This shell required several steps for each station:

a) The shell first requested a DAS serial number for processing. It then looked for the data on disk for the desired DAS either in rawrefdump format or in SEGY format. It notified the operator if no data were found on disk. In this case the data in rawrefdump format were read from archival tape to disk using ref2segy - $\mathbf{t} / \mathbf{d e v} / \mathbf{r m t} / \mathbf{3 n}$ (after positioning the archival tape to the first file of the desired station data using $\mathbf{m t} \mathbf{- f} / \mathbf{d e v} / \mathbf{r m t} / \mathbf{3 n} \mathbf{f s f} \mathbf{I}$ where $\mathrm{I}=0,3,6,9,12$, etc.). The program ref2segy also converted the data from rawrefdump format to SEGY format and generated logfiles for the data.

b) SegyGather.csh then ran ref2segy on all rawrefdump-formatted data and placed the converted SEGY data into directories for each Julian Day, e.g., R070.01.

c) The shell determined whether all the logfiles were available on disk or whether any logfiles needed to be imported from /export/home/field/SHIPS98.workingfiles/logfiles. Duplicate logfiles were also identified so that they could be eliminated manually.

d) From the logfiles the shell determined whether refrate timing corrections were needed using the logic previously described. This step was verified by the operators by visually examining a plot of the clock logfile using clockview. If the GPS clock drifted less than $10 \mathrm{msec}$ between time corrections (time jerks) at intervals less than a day throughout the deployment, then no timing corrections were needed. If not, or if the Reftek was manually pulsed, program refrate was run to create Passcal Correction Files (.pcf) from the DAS log files [e.g., refrate *.DAS\#.log >DAS\#.pcf] to correct the timing on the recorded data. Appendix 
3 provides documentation of whether refrate was run for each station, and usually indicates why.

e) The shell then checked for missing 30-minute-long or 60-minute-long events from the SEGY data for each Julian Day. Links to these data were placed in /tmp/Inputlistn, where n represented the seismic line number (1 to 11). Missing data were flagged for the operator's notice. Usually missing data were located at the beginning and end of the deployment, but were also noted when stations were visited during the deployment.

f) SegyGather.csh next created scripts to write SEGY-formatted common-receiver gathers to archival tape using segygather. These scripts wrote two identical DLT tapes and one DAT tape for each line recorded by every DAS. The scripts were named writetape0, writetape1, and writetape 3 and wrote to the $/ \mathrm{dev} / \mathrm{rmt} / 0$ (DLTA), /dev/rmt/1 (DAT), and /dev/rmt/3 (DLTB). Channel 1 = vertical geophone, Channel $2=\mathrm{N}-\mathrm{S}$ oriented horizontal geophone, and Channel 3 = E-W oriented horizontal geophone. [For the six-channel Reftek 08's, Channel 4 $=$ vertical geophone, Channel $5=\mathrm{N}-\mathrm{S}$ oriented horizontal geophone, and Channel $6=\mathrm{E}-\mathrm{W}$ oriented horizontal geophone.] This script wrote the source and receiver locations and elevations (in meters) for each trace. Note that the latitudes and longitudes in the trace headers must be divided by 36,000 to yield decimal latitude and longitude in degrees. Unfortunately, we were not also able to write source and receiver locations in other coordinate systems to the trace headers using this script.

g) At this point the shell provided the operator the opportunity to proceed to write the gathers to tape or to quit the program. This option gave the operator the opportunity to verify (1) that the tape drives were correctly positioned, (2) that links to the SEGY data had been properly made, and (3) to determine that the pathnames in the writetape 0 , writetape 1 , and writetape 3 
scripts were correct. At this stage the operator edited the writetape0, writetape1, and writetape 3 scripts so that the pathnames for the source-receiver range tables for the Reftek 08's were correct (the leading zero on these DASs were inadvertently left off of these files).

h) The shell ran the segyreelmod program to add the source-receiver offsets to the headers for each trace. Note that only the absolute value of source-receiver offset, in integer meters, was written in the header. No value was assigned for the signed source-receiver offset.

i) The script then ran segymerge to make separate traces for earthquakes from a list of 62 local earthquakes and quarry blasts that occurred during our deployment. These earthquakes were stored in SEGY format in the EQ directory for each working directory and then archived to tape using tar commands. The earthquakes and blasts archived to tape are listed in Table 6 . Events listed in either the University of Washington (UW) or the Pacific Geoscience Centre (PGC) earthquake catalogs were archived. Events 120001 to 120036 are events from the UW catalog. Events 120037 to 120062 are from the PGC catalog. Events 120014 and 120046 represent the same earthquake recorded by the two different arrays, it is a magnitude 2.7, low frequency earthquake located $4.5 \mathrm{~km}$ ENE of Mount Baker. This event was the largest local earthquake which occurred during our deployment. Ninety seconds of unreduced data were saved for each event. A separate SEGY trace is saved for each event and each receiver. Thus, for each tape the traces are saved in 62 separate directories, one for each event, with a variable number of traces, representing a separate trace for each component recorded at a station (up to a maximum of about 410). The data values for each trace are preceded by a 240 byte header. The format of the header is given in Appendix 6. All integer values are stored with the most significant byte first. Data values are 16 or 32 bit integers depending upon byte 206 of the header. Tape copies are available from the 
IRIS/PASSCAL Data Management Center. Although there is a SEGY trace header for each trace, there is no IBM SEGY tape label header.

j) A script was written (by N.P. Symons), named catalog_tape, to verify the contents of each DLT tape and to determine the location on the tape of any zerofiles, discussed below.

\section{Notes on Data Reduction:}

1) During the data reformatting data volumes were expanded by a factor of 3.6. The ninety-second records of unreduced data archived for each airgun shot resulted in the following approximate data volumes for each station: (1) 0.6 Gbytes for a single-component Reftek Model 06, (2) 1.2 Gbytes for a single-component Reftek Model 07, (3) 3.6 Gbytes for a three-component Reftek Model 07 or 08.

2) A list was tabulated showing the location of the Reftek station data on the archival tapes (Appendix 5). The three major columns in Appendix 5 show the file numbers written to the two DLT tapes and a DAT tape for each DAS (station). This table is valuable because the processing of stations was not always in numerical order. At first, stations having 12 second jumps were skipped; the table lists where these skipped stations may be found. Also, at some stations the processing was redone when errors were found in the initial processing. For instance, when the program was improperly used the files written to the tape would contain lines without any traces. In Appendix 5 we call these files zerofiles, and many commercial software packages can not read them. However, using mt -f /dev/nrst5 fsf and mt -f /dev/nrst5 bsf commands, it is possible to space through these zerofiles. The zerofiles are more prevalent on the first few tapes written than for the later tapes made. Horizontal component data on Channels 3 and 6 were inadvertently written on the first few tapes instead of vertical component data for 
Channels 1 and 4. For this, and many other reasons, data from a station were processed more than once to insure that all the useful data were processed properly.

\section{The most useful data for a station will be that last archived to tape. A short unix program useful for copying all or parts of the SEGY Reftek tapes is provided at the end of Appendix 5.}

3) Several stations which did not record all or parts of seismic lines were noted. In the comments columns of Appendix 5 we note any seismic lines for which there are no data for the Reftek DAS. Data generally are lacking due to DAS failure. In addition, a handful of stations produced little or no useful data including: stations 1001, 10006, 10029, and 10041.

4) During processing we noted that 29 Refteks using a particular series of external hard drives experienced 12 second jumps. The affected stations and data are tabulated in Appendix 4. A special shell (fix12secbug) was used to correct this problem for each of these stations. In Appendix 3 we indicate whether, when fix12secbug was run, there was any problem detected in the logfiles. If not, no further processing was required. If so, then it was necessary to run the scripts generated by fix12secbug.

5) The shell described above initially did not successfully process all three components of the 3component stations. For this reason, we chose to first process the vertical component data for all stations, and then following completion of this task, we processed the horizontal components of the data. Appendix 5 lists where the horizontal components for each of these stations may be located on tape. 
6) The Reftek clock at several stations either was not reset from or was inadvertently reset to the default year of $\mathbf{1 9 8 8}$ (these stations are identified in Appendix 3). To fix these problems the logfiles of these stations were edited to replace 1988 by 1998 and the event file names were renamed from 1988 to 1998 . In addition segyreelhdr was run to change 1988 to 1998 in the event files.

7) The complete SHIPS wide-angle dataset reformatted to SEGY common-receiver gathers requires 32 DLT tapes (10 to 20 Gbytes each) and 214 DAT tapes (2 to 4 Gbtyes). All tapes are labeled as indicated on Appendix 5.

8) The processing of the rawrefdump-formatted data into SEGY-formatted common-receiver gathers started on July 20th, 1998 and was completed September 3, 1998 using 2 separate workstations.

\section{Passcal Modified SEGY Trace Format}

The common receiver gathers generated from the digital Reftek tapes were written in an unreduced travel time format. Ninety-seconds of data were saved for each trace, starting at the airgun origin time. At a sample rate of $10 \mathrm{~ms}$, there are 9001 samples per trace, for a block length, including header, of either 18242 or 36244 bytes per trace (depending on whether the data are 16 or 32 bit integers, see the next paragraph). The time interval between traces is $40 \mathrm{~s}$ for the wide-angle lines (FFIDs 10001-53190) and approximately $20 \mathrm{~s}$ for the multichannel seismic reflection lines (FFIDs 60001-112711).

The common receiver gathers were written in SEGY format to DLT and DAT tape by the segygather program. SEGY trace header formats described by Barry et al. (1975) were modified slightly, as described in Appendix 6. The modification comes from the fact that we use some of the 
unspecified header words to store information pertinent to the PASSCAL data. The data values for each trace are preceded by a 240 byte header. The format of the header is given in Appendix 6 . All integer values are stored with the most significant byte first. Data values are 16 or 32 bit integers depending upon byte 206 of the header. Tape copies are available from the IRIS/PASSCAL Data Management Center. Note that the latitudes and longitudes in the trace headers must be divided by 36,000 to yield decimal latitude and longitude in degrees.

\section{DATA QUALITY}

Examples of the Reftek data recorded during SHIPS are provided in Figures 28 to 41. These figures illustrate a very limited subset of the available wide-angle data. Figures 28 and 29 show data recorded along the south shore of the Strait of Juan de Fuca. Figures 30 to 32 show data recorded along the Strait of Georgia. To illustrate the station-to-station variability in data quality, Figures 33 to 39 show data recorded on Whidbey Island at adjacent stations 1011 to 1017 . Figures 40 and 41 show data recorded in the southern end of Puget Lowland. Although the quality of the wide-angle data recorded on land ranged from excellent to poor, in Figures 28 to 41 we present the higher quality data. On balance, most stations provided usable data to source-receiver offsets of at least 40 to $50 \mathrm{~km}$, although airgun signals can be observed to much greater ranges at remote bedrock sites. Airgun signals are difficult to detect at some soft soil sites in urban or suburban localities. In some of these locations, very few interpretable data were recorded.

Weather conditions more favorable than might be expected during March were encountered, and this favorable weather undoubtedly contributed to the data quality. There were few extended periods of high winds during the experiment.

\section{DESCRIPTION OF THE DATA}


The Reftek and OBS data acquired during the SHIPS experiment show several interesting seismic arrivals. Refractions and direct arrivals from the sedimentary basin fill were well recorded as first and secondary arrivals by both the OBSs and Refteks (e.g. Figures 23, 27, and 40). Refractions from the upper crust, Pg, were routinely recorded (Figures 12 to 41). Many Pg arrivals from shots from the Strait of Juan de Fuca and the Strait of Georgia have apparent velocities close to $6.5 \mathrm{~km} / \mathrm{s}$ (e.g. Figures 29 to 31), suggesting a relatively high-velocity upper and middle crust. Refractions from the upper mantle, Pn, can be observed (Figure 32, ranges greater than $200 \mathrm{~km}$ ). Large-amplitude secondary reflected arrivals are prominent on records from shots along the Strait of Juan de Fuca (e.g. Figures 29 and 30). Travel times of arrivals from shots within the Puget Lowland show pronounced delays associated with the Tacoma, Seattle and Everett basins (e.g. Figures 33 to 41). The Seattle fault is associated with a significant travel time delay (e.g., Figure 40 between $\mathrm{km} 54$ and 60).

Three examples of local earthquakes recorded during our Reftek deployment are shown in Figures 42 to 44 . In these plots, the traces are ordered from nearest to farthest from the earthquake epicenters. Only data from stations in Puget Sound deployed by the USGS and the University of Washington (1001-8014, 10001-10060) have been plotted in these figures. The plots have been reduced using a velocity of $6.8 \mathrm{~km} / \mathrm{s}$ and the traces have been shifted down by 5 seconds to illustrate the noise prior to the first arrivals. The events shown in these figures, 120006, 120018, and 120028, are the best recorded earthquakes and produced the largest signal-to-noise ratios observed during our SHIPS Reftek deployment. Shear-wave arrivals are clearly observed on events 120006 and 120018 and are less clear for event 120028. 


\section{DATA AVAILABILITY}

Tape copies of the Reftek seismic data may be ordered via email from the IRIS/PASSCAL Data Management Center (DMC) in Seattle, Washington. The current email address of the Incorporated Research Institutions for Seismology (IRIS) Consortium is: www.iris.edu. The current general email address for the IRIS DMC is webmaster@iris.washington.edu. The current address of the IRIS DMC is: 1408 NE 45th St., Suite 201, Seattle, WA 98105. telephone (206) 547-0393. Tim Ahern is currently the Program Manger of the IRIS Data Management System at Seattle.

The text of this Open-File Report is available via anonymous ftp. The anonymous ftp address is: andreas.wr.usgs.gov. Change the directory (cd) to /pub/outgoing/puget. The text is in a file named OFR99314.

A short unix program to copy all or part of the SEGY tapes of the Reftek data is provided at the end of Appendix 5. This program copies tapes containing zerofiles. 


\section{ACKNOWLEDGMENTS}

In the USA, Tom Burdette, USGS, organized and arranged permits for the field work. Tanni Abramovitz, Becky Barnhart, Jeff Brody, Tom Burdette, Katherine Favret, Pat Hart, Charlotte Keller, Adrian Kropp, Karen Meagher, Diane Minasian, Janice Murphy, Bob Norris, Ray Sliter, Lori Tapia-Piozet, and Tom Yelin, USGS, as well as Alex Gerst, Sonja Hofmann, Uli Micksch, and Andy Wuestefeld, all undergraduate students at the University of Karlsruhe, helped deploy and maintain the Reftek array. Brett Hiett, Fiona Kilbride, Terry O'Donnell, Jr., Kathy Snelson, Annette Veilleux, all of UTEP, Dean Childs, BSU, Steve Azevedo, OSU, Shari Curry, OSU, and Cormack Craven, OSU, Tony Qamar, UW, and George Thomas, UW, also helped deploy and maintain instruments.

In Canada, Tianson Yuan, Yanpeng Mi, Alex Smith, Brian Creaser, Nilanjan Ganguly, and Anubrati Mukherjee (UVic) plus Holger Mandler and Baishali Roy (UBC) helped deploy and maintain the Reftek instruments.

We thank Alan Cooper, Jon Childs, Guy Cochran, and Mike Hamer, USGS and others who served on the Thompson science party. Mike Hamer, USGS, provided the airgun shottime and location file. We thank those who served on the science party of the CCGS Tully. We thank the captains and crews of the CCGS Vector and CCGS Tully for their seamanship and help during the Dalhousie OBS deployment and recovery, respectively.

We thank the Washington State Departments of Forestry and Parks and Recreation, Olympic National Forest, the Bureau of Land Management for permission to access land under their jurisdiction. We thank the Weyerhaeuser Corp., International Paper Co., and numerous smaller property owners for permission to access their land. We thank Graysmarsh Farms, Harry and Zoe Ann Dudley, Olympic National Park (Paul Crawford), Makah Indian Nation (Denise Daley), U.S. Coast Guard (for a boat trip to an island site), Ft. Flagler State Park, Ft. Worden State Park, Anderson Lake State Park, Crown Point Timber Co., Merrill and Ring tree farm and timber, Rayonier tree nursery (Stuart Smith), and Elwah Rock Quarry (Russell Myron) for permission to access their land.

We thank Russ Sells and Allan Swisenbank at the IRIS/PASSCAL Instrument facility (at Stanford) for helping to prepare the Reftek instruments used in this experiment, for teaching us how to use them, and for trouble shooting our problems in the field. Russ and Allan helped us reduce the data into SEGY record sections. Steve Azevedo, OSU, Jeff Brody, USGS, Brian Creaser, UVic, Katherine Favret, USGS, Brett Hiett, UTEP, Leiph Preston, UW, and Craig Tiballi, USGS helped to process the common-receiver gathers. Phil Molzer, USGS, plotted the record sections for the USGS OBSs, and for stations 1011 to 1017.

We thank NOAA-PMEL for the use of their vessel and facilities for staging, deployment, and recovery of the USGS OBSs, Captain Speer for his professional operation of the SP Hayes, and 
Gregory Miller, Michael Taylor, Alvin Buchholtz for their help during USGS OBS field operations. We thank Bob Iuliucci for assisting with the deployment of the Dalhousie OBSs.

Art Frankel and Dave Carver, USGS/Golden graciously provided the coordinates of their 13 strong ground motion stations in West Seattle deployed during SHIPS.

Jim Luetgert, USGS, critically reviewed this report.

This work was supported by the USGS Marine and Coastal Studies Program, the USGS Urban Hazards Initiative, and external grants from the USGS National Earthquake Hazards Reduction Program to Oregon State University, the University of Texas El Paso, and the University of Washington. Additional funding for SHIPS was provided by the Geological Survey of Canada, the U.S. Minerals Management Service, and the USGS Venture Capital Fund. 


\section{REFERENCES CITED}

Atwater, B.F., and Hemphill-Haley, E., 1997, Recurrence intervals for great earthquakes of the past 3,500 years at northeastern Willapa Bay, Washington: U.S. Geological Survey Professional Paper 1576, 108 p.

Atwater, B.F., 1987, Evidence for great Holocene earthquakes along the outer coast of Washington State, Science, 236, 942-944.

Atwater, B.F., and Moore, A.L., 1992, A tsunami about 1000 years ago in Puget Sound, Washington, Science, v. 258, p. 1614-1617.

Atwater, B.F., 1996, Coastal evidence for great earthquakes in western Washington, U.S. Geological Survey, Professional Paper 1560, p. 77-90.

Barry, K.M., D.A. Cravers, and C.W. Kneale, 1975, Recommended standards for digital tape formats: Geophysics, v. 40, p. 344-352.

Blakely, R.J., Wells, R.E., Haugerud, R., Pratt, T.L., Weaver, C.S., and others, 1999, Tectonic framework and earthquake hazards of the Puget Lowland: Evidence from new aeromagnetic data: Geology, v. 27, in preparation.

Brocher, T.M. and Ruebel, A.L., 1998, Compilation of 29 sonic and density logs from 23 oil test wells in western Washington State, U.S. Geological Survey Open-File Report 98-249, 41 p.

Bucknam, R.C., Hemphill-Haley, E., and Leopold, E.B., 1992, Abrupt uplift within the past 1700 years at southern Puget Sound, Washington, Science, v. 258, p. 1611-1614.

Calvert, A.J., 1996, Seismic reflection constraints on imbrication and underplating of the northern Cascadia convergent margin, Canadian J. Earth Sciences, 33, 1294-1307.

Chopra, S., M.A. Fisher, D.M. Mosher, R.K. Walia, R.D. Hyndman, G.D. Spence, 1998, The 'SHIPS' study of seismic structure and seismic hazard in Puget Sound, Georgia Strait and Strait of Juan de Fuca, EOS Trans., AGU, 79(45), Fall Meet. Suppl., F898.

Clowes, R.M., Yorath, C.J., and Hyndman, R.D., 1987, Reflection mapping across the convergent margin of western Canada, Geophys. J. Roy. Astron. Soc., 89, 79-84.

Clowes, R.M., Brandon, M.T., Green A.G., Yorath, C.J., Sutherland Brown, A., Kanasewich, E.R., and Spencer, C.J., 1987, LITHOPROBE-southern Vancouver Island: Cenozoic subduction complex imaged by deep seismic reflections: Canadian Journal of Earth Sciences, v. 24, p. 31-51.

Clowes, R.M., Zelt, C.A., Amor, J.R., and Ellis, R.M., 1995, Lithospheric structure in the southern Canadian Cordillera from a network of seismic refraction lines: Canadian Journal of Earth Sciences, v. 32, p. 1485-1513.

Fisher, M.A., T.M. Brocher, R.D. Hyndman, A.M. Trehu, C.S. Weaver, K.C. Creager, R.S. Crosson, T. Parsons, A.K. Cooper, D. Mosher, G. Spence, B.C. Zelt, P.T. Hammer, U. ten Brink, T.L. Pratt, K.C. Miller, J.R. Childs, G.R. Cochrane, S. Chopra, and R. Walia, 1999, 
Seismic survey probes urban earthquake hazards in Pacific Northwest, EOS, Trans. Amer. Geophys. Un., v. 80, no. 2, p. 13-17.

Flueh, E., M. Fisher, D. Scholl, T. Parsons, U. ten Brink, D. Klaeschen, N. Kukowshi, A. Tréhu, J. Childs, J. Bialas, and N. Vidal, 1997, Scientific teams analyze earthquake hazards of the Cascadia subduction zone: Eos (Transactions, American Geophysical Union), p. 153-157.

Heaton, T.H., and H. Kanamori, 1984, Seismic potential associated with subduction in the northwestern United States: Seismological Society of America Bulletin, v. 74, p. 933-941.

Heaton, T.H., and S.H. Hartzell, 1987, Earthquake hazards on the Cascadia subduction zone, Science, v. 236, p. 162-168.

Hyndman, R.D., and K. Wang, 1993, Thermal constraints of major thrust earthquake failure: The Cascadia subduction zone: Journal of Geophysical Research, v. 98, p. 2039-2060.

Hyndman, R.D., Yorath, C.J., Clowes, R.M., and Davis, E.E., 1990, The northern Cascadia subduction zone at Vancouver Island: Seismic structure and tectonic history, Can. J. Earth Sci., 27, p. 313-329.

Johnson, S.Y., 1993, Analysis of Cenozoic subsidence at three sites in vicinity of the Seattle basin, Washington: U.S. Geological Survey Open-File Report 93-332, 17 p.

Johnson, S.Y., Potter, C.J., and Armentrout, J.M., 1994, Origin and evolution of the Seattle fault and Seattle basin, Washington, Geology, v. 22, p. 71-74.

Johnson, S.Y., Potter, C.J., Armentrout, J.M., Miller, J.J., Finn, C., and Weaver, C.S., 1996, The southern Whidbey Island fault, western Washington-An active structure in the Puget Lowland, Washington: Geological Society of America Bulletin, v. 108, p. 334-354, and oversized insert.

Johnson, S.Y., Tennyson, M.E., Lingley, W.S., and Law, B.E., 1993, Petroleum geology of the State of Washington: U.S. Geological Survey, Professional Paper 1582, 40 pp.

Jones, M.A., 1994, Thickness of unconsolidated deposits in the Puget Sound Lowland, Washington and British Columbia, U.S. Geological Survey, Water Resources Investigations Report (WRIR) 94-4133.

Luetgert, J., Mooney, W.D., Criley, E., Keller, G.R., Gridley, J., Miller, K., Trehu, A, Nabelek, J., Smithson, S.B., Humphreys, C., Christensen, N.I., Clowes, R., Asudeh, I., 1992, Crustal velocity structure of the Pacific NW: The 1991 seismic refraction/wide-angle reflection: The Geological Society of America, Abstracts with Programs, v. 24, no. 5, p. 66.

Miller, K.C., Keller, G.R., Gridley, J.M., Luetgert, J.H., Mooney, W.D., and Thybo, H., 1997, Crustal structure along the west flank of the Cascades, western Washington, J. Geophysical Res., v. 102, 17,857-17,873.

Parsons, T., A.M. Tréhu, J.H. Luetgert, K. Miller, F. Kilbride, R.E. Wells, M.A. Fisher, E. Flueh, U.S. ten Brink, and N.I. Christensen, 1998, A new view into the Cascadia subduction zone and volcanic arc: Implications for earthquake hazards along the Washington margin, Geology, 26, 199-202. 
Parsons, T., R.E. Wells, M.A. Fisher, E. Flueh, and U.S. ten Brink, in press, Three-dimensional velocity structure of Siletzia and other accreted terranes in the Cascadia fore arc of Washington, J. Geophys. Res.

PASSCAL, 1991, Users Guide, A Guide to Planning Experiments Using PASSCAL Instruments: IRIS, $28 \mathrm{pp}$.

Pratt, T.L., S. Johnson, C. Potter, W. Stephenson, and C. Finn, 1997, Seismic reflection images beneath Puget Sound, western Washington state: The Puget Lowland thrust sheet hypothesis, J. Geophys. Res., 102, 27,469-27,489.

Symons, N., 1998, Seismic velocity structure of the Puget Sound region from 3-D non-linear tomography, Ph. D. thesis, Univ. Washington, $168 \mathrm{p}$.

Symons, N.P. , and Crosson, R.S., 1997, Seismic velocity structure of the Puget Sound region from 3-D non-linear tomography, Geophys. Res. Lett., v. 24, p. 2593-2596.

Weaver, C.S., and Baker, G.E., 1988, Geometry of the Juan de Fuca plate beneath Washington and northern Oregon from seismicity, Bulletin of the Seismological Society of America, v. 78, p. 264-275.

Weaver, C.S., Blakely, R.J., Wells, R.E., and others, 1999, An active fault beneath Seattle: Science, in preparation.

Wells, R.E., and Heller, P.L., 1988, The relative contribution of accretion, shear, and extension to Cenozoic tectonic rotation in the Pacific Northwest: Geological Society of America Bulletin, v. 100, p. 325-338.

Wells, R.E., Weaver, C.S., and Blakely, R.J., 1998, Fore-arc migration in Cascadia and its neotectonic significance, Geology, 26, 759-762. 


\section{TABLE 1. R/V Thompson Line Locations and Acquisition Times During 1998 SHIPS}

\begin{tabular}{|c|c|c|c|}
\hline \multicolumn{2}{|c|}{ Start of Line } & \multicolumn{2}{|c|}{ End of Line } \\
\hline \multicolumn{2}{|l|}{ UTC } & \multicolumn{2}{|l|}{ UTC } \\
\hline$\underline{\mathrm{JD}} \underline{\mathrm{HR}} \underline{\mathrm{MN}}$ & Latitude Longitude & $\underline{\mathrm{JD}} \underline{\mathrm{HR}} \underline{\mathrm{MN}}$ & Latitude Longitude \\
\hline \multicolumn{4}{|c|}{ Line 1 - LW1 - Lake Washington (Wide-angle) } \\
\hline 0691924 & $47.68941-122.24087$ & 0692259 & $47.69338-122.24801$ \\
\hline \multicolumn{4}{|c|}{ Line 2 - WA1 - Western Puget Sound from Seattle to entrance of Carr Inlet } \\
\hline 0701003 & $47.71172-122.49077$ & 0701731 & $47.21594-122.59340$ \\
\hline \multicolumn{4}{|c|}{ Line 3 - WA1 - Carr Inlet to southern end of Possession Sound (Wide-angle) } \\
\hline 0701923 & $47.32157-122.72075$ & 0712342 & $48.14034-122.38664$ \\
\hline \multicolumn{4}{|c|}{ Line 4 - WA1 - Saratoga Passage (Wide-angle) } \\
\hline 0720121 & $48.05701-122.32777$ & 0720559 & $48.24547-122.57020$ \\
\hline \multicolumn{4}{|c|}{ Line 5 - WA1 -Hood Canal, Strait of Juan de Fuca, Strait of Georgia (WA) } \\
\hline 0721427 & $47.82988-122.39290$ & 0770128 & $49.79598-124.69054$ \\
\hline \multicolumn{4}{|c|}{ Line 6 - SG1 - Strait of Georgia southbound (MCS) } \\
\hline 0780033 & $49.69853-124.71415$ & 0790850 & $48.21493-123.30816$ \\
\hline \multicolumn{4}{|c|}{ Line 7 - JDF1 outbound (MCS) } \\
\hline 0790902 & $48.21226-123.32931$ & 0792113 & $48.53839-124.64211$ \\
\hline \multicolumn{4}{|c|}{ Line 8 - JDF2 inbound (MCS) } \\
\hline 0792348 & $48.40921-124.61268$ & 0801759 & $48.09106-122.66223$ \\
\hline \multicolumn{4}{|c|}{ Line 9 - PS1 southbound (MCS) } \\
\hline 0801800 & $48.08977-122.66191$ & 0810619 & $47.31891-122.46395$ \\
\hline \multicolumn{4}{|c|}{ Line 10 - PS2 northbound (MCS) } \\
\hline 0810627 & $47.32112-122.44772$ & 0821128 & $48.12793-122.87618$ \\
\hline \multicolumn{4}{|c|}{ Line 12 - JDF3 (MCS) } \\
\hline 0821140 & $48.11703-122.89047$ & 0821744 & $48.41048-123.12624$ \\
\hline \multicolumn{4}{|c|}{ Line 12 - JDF4 (MCS) } \\
\hline 0821744 & $48.41048-123.12624$ & 0822213 & $48.18368-123.26686$ \\
\hline \multicolumn{4}{|c|}{ Line 13 - JDF5 (MCS) } \\
\hline 0822215 & $48.18513-123.26546$ & 0830222 & $48.40327-123.02095$ \\
\hline
\end{tabular}

Line 14 - JDF6 (MCS) 
$\underline{0830223}$ $48.40314-123.01924$

0830345

$48.31285-123.01163$ 
TABLE 2. Expanding Spread Profiles (ESPs) Locations and Offsets

\begin{tabular}{lllll}
$\underline{\text { ESP }}$ & Location & $\underline{\text { Northing }(\mathrm{m})}$ & $\underline{\text { Easting }(\mathrm{m})}$ & $\begin{array}{l}\text { Min./Max. } \\
\text { Offset (m) }\end{array}$ \\
1 & Hood Canal & $5273000 \pm 2000$ & $507250 \pm 1750$ & $0 / 60000$ \\
2 & E. Strait of Juan de Fuca & $5337500 \pm 4000$ & $513800 \pm 2000$ & $2000 / 48000$ \\
3 & W. Strait of Juan de Fuca & $5358000 \pm 300$ & $423900 \pm 1250$ & $0 / 80000$ \\
4 & Strait of Juan de Fuca & $5347900 \pm 2000$ & $417500 \pm 2500$ & $100 / 72000$ \\
5 & Strait of Georgia & $5411500 \pm 450$ & $494850 \pm 1000$ & $0 / 46000$ \\
6 & Strait of Georgia & $5273000 \pm 2000$ & $507200 \pm 1750$ & $0 / 46000$ \\
7 & Strait of Georgia & $5510500 \pm 700$ & $397500 \pm 500$ & $0 / 36000$ \\
8 & Puget Sound & $5264000 \pm 2500$ & $540500 \pm 2500$ & $8000 / 50000$ \\
9 & Puget Sound & $5270200 \pm 2000$ & $543000 \pm 2000$ & $2000 / 60000$ \\
11 & E. Strait of Juan de Fuca & $5347600 \pm 800$ & $483500 \pm 2500$ & $5000 / 29000$ \\
12 & E. Strait of Juan de Fuca & $5348200 \pm 600$ & $488400 \pm 400$ & $0 / 34000$ \\
& & & & \\
\hline
\end{tabular}

Note: These UTM coordinates are given for Zone 10. 
TABLE 3. Revised Line Numbers and FFIDs for Making SEGY Common-Receiver Gathers

Reftek

Line

No. Geographic Location

Thompson Line Number and FFIDS

Line 1 Lake Washington

Line 1 (LW), FFIDs 001-324

Line 2 Puget Sound southbound

(western passage)

Line 2, FFIDs 0001-0633

Carr Inlet

Line 3, FFIDs 0001-0180

Puget Sound

Lower Puget Sound south bound

Line 3, FFIDs 0181-0310

Lower Puget Sound north bound

Line 3, FFIDs 0311-0580

Puget Sound northbound

(eastern passage)

Line 3, FFIDs 0581-0838

Saratoga Passage

Line 3, FFIDs 0839-2403

Line 4, FFIDs 0001-0419

Line 3 Puget Sound westbound

Line 5 (WA), FFIDs 0001-0223

Hood Canal southbound

Line 5 (WA), FFIDs 0224-1259

Hood Canal northbound

Line 5 (WA), FFIDs 1260-2200

Puget Sound northwestbound

Line $4 \quad$ Strait of Juan de Fuca west bound

Line 5 (WA), FFIDs 2200-2450

Strait of Juan de Fuca east bound

Line 5 (WA), FFIDs 2451-4771

Line 5 (WA), FFIDs 4772-6076

Line 5 San Juan Islands

Strait of Georgia (US Waters)

Line 5 (WA), FFIDs 6077-6680

Line 5 (WA), FFIDs 6681-7603

Strait of Georgia (Canadian waters, eastern passage)

Line 5 (WA), FFIDs 7604-9512

Line 6 Strait of Georgia (Canadian waters, western passage)

Strait of Georgia (US waters)

Line 6 (SG1), FFIDs 0001-2690

Line 6 (SG1), FFIDs 2691-3646

San Juan Islands

Line 6 (SG1), FFIDs 3647-4500

Eastern Juan de Fuca west bound

Line 6 (SG1), FFIDs 4501-5345

Line $7 \quad$ Strait of Juan de Fuca west bound

Line 7 (JDF1)

Line 8 Strait of Juan de Fuca east bound

Line 8 (JDF2)

Line 9 Puget Sound south bound

Line 9 (PS1), FFIDs 0001-2111

Puget Sound north bound

Line 10 (PS2), FFIDs 0001-2511

Line 10 Eastern Strait of Juan de Fuca

Line 10 (PS2), FFIDs 2512-4964

Line 11

Eastern Strait of Juan de Fuca

Lines 11-14 (JDF3-6) 
Table 4. List of Reftek Lines, FFIDs, Locations, and Start and Stop Times

\begin{tabular}{|c|c|c|c|c|c|}
\hline $\begin{array}{r}\underline{\text { Reftek }} \\
\underline{\text { Line No. }}\end{array}$ & $\frac{\text { Reftek First }}{\underline{\text { FFID }}}$ & $\frac{\text { Reftek Last }}{\underline{\text { FFID }}}$ & Location & $\frac{\mathrm{JD}: \text { HrMin }}{\mathrm{UTC}}$ & $\frac{\text { JD:HRMin }}{\text { UTC }}$ \\
\hline 1 & 10001 & 10324 & Lake Washington & 069:1924 & 069:2259 \\
\hline 2 & 20001 & 20633 & Puget Sound & 070:1003 & \\
\hline 2 & 20634 & 20813 & Carr Inlet & & \\
\hline 2 & 20814 & 20943 & Puget Sound & & \\
\hline 2 & 20944 & 21213 & $\begin{array}{l}\text { S. Puget Sound } \\
\text { (southbound) }\end{array}$ & & \\
\hline 2 & 21214 & 21472 & S. Puget Sound & & \\
\hline 2 & 21473 & 23039 & $\begin{array}{c}\text { Puget Sound } \\
\text { northbound }\end{array}$ & & \\
\hline 2 & 23040 & 23458 & Saratoga Passage & & 072:0559 \\
\hline 3 & 30001 & 30223 & NW Puget Sound & 072:1427 & \\
\hline 3 & 30224 & 31259 & $\begin{array}{l}\text { Hood Canal } \\
\text { (southbound) }\end{array}$ & & \\
\hline 3 & 31260 & 32200 & $\begin{array}{l}\text { Hood Canal } \\
\text { (northbound) }\end{array}$ & & \\
\hline 3 & 32201 & 32391 & $\begin{array}{l}\text { Puget Sound (northwest } \\
\text { bound) }\end{array}$ & & 073:1740 \\
\hline 4 & 40001 & 42320 & $\begin{array}{l}\text { St. of Juan de Fuca } \\
\text { (westbound) }\end{array}$ & 073:1741 & \\
\hline 4 & 42321 & 43601 & $\begin{array}{l}\text { St. of Juan de Fuca } \\
\text { (eastbound) }\end{array}$ & & 075:1002 \\
\hline 5 & 50001 & 50604 & San Juan Islands & 075:1003 & \\
\hline 5 & 50605 & 51527 & St. of Georgia (US) & & \\
\hline 5 & 51528 & 53190 & St. of Georgia (Canada) & & 077:0128 \\
\hline 6 & 60001 & 62690 & St. of Georgia (Canada) & 078:0033 & \\
\hline 6 & 62691 & 63646 & St. of Georgia (US) & & \\
\hline 6 & 63647 & 64500 & San Juan Islands & & \\
\hline 6 & 64501 & 65342 & E. St. Juan de Fuca & & 079:0850 \\
\hline 7 & 70001 & 72111 & St. Juan de Fuca & 079:0902 & 079:2113 \\
\hline 8 & 80001 & 83092 & St. Juan de Fuca & 079:2348 & 080:1759 \\
\hline 9 & 90001 & 92111 & $\begin{array}{l}\text { Puget Sound } \\
\text { southbound }\end{array}$ & 080:1800 & \\
\hline 9 & 92112 & 94622 & $\begin{array}{l}\text { Puget Sound } \\
\text { northbound }\end{array}$ & & 081:2041 \\
\hline
\end{tabular}


100001

102453

110001

110994

111728

112467

11

111727

112466

112711
E. St. Juan de Fuca

081:2041

082:1128

JDF4

JDF5

JDF6

JDF7

082:1140

083:0345 
TABLE 5. List Of Airgun Array Ramp-Ups Times

UTC

$\underline{\text { JD }} \underline{\mathrm{HR}} \underline{\mathrm{MN}} \quad \underline{\text { Latitude }} \underline{\text { Longitude }} \quad \underline{\text { Notes }} \quad \underline{\text { Line (Thompson Line, FFID) }} \quad \underline{\text { Reftek FFID }}$

\begin{tabular}{|c|c|c|c|c|}
\hline 0701453 & $47.36998-122.53110$ & guns off - seal & WA1 (Line 2, FFID 436) & 20436 \\
\hline 0701521 & $47.33922-122.54749$ & start ramping guns & & \\
\hline 0710505 & $47.13800-122.66895$ & guns off - fouled & WA1 (Line 3, FFID 874) & 21508 \\
\hline 0710642 & $47.20268-122.59590$ & start ramping guns & & \\
\hline 0712342 & $48.14034-122.38664$ & guns off & WA1 (Line 4, FFID 240) & 23279 \\
\hline 0720121 & $48.05701-122.32777$ & start ramping guns & & \\
\hline 0721841 & $47.86674-122.61445$ & guns off, Hood Canal Br. & WA1 (Line 5, FFID 382-415) & 30383 \\
\hline 0721903 & $47.84647-122.64186$ & start ramping guns & & \\
\hline 0731258 & $47.84757-122.63583$ & guns off, Hood Canal Br. & WA1 (Line 5, FFID 2027-2055) & 31996 \\
\hline 0731317 & $47.86545-122.61673$ & start ramping guns & & \\
\hline 0731807 & $48.22383-122.85925$ & guns off, mammals & WA1 (Line 5, FFID 2490-2516) & 41040 \\
\hline 0731824 & $48.24603-122.88072$ & start ramping guns & & \\
\hline 0752350 & $48.95926-123.39352$ & guns off, boat fouled & WA1 (Line 5, FFID 7318-7565) & 51242 \\
\hline 0760237 & $48.97275-123.39157$ & start ramping guns & & \\
\hline 0761425 & $49.28288-124.00117$ & guns off, mammals & WA1 (Line 5, FFID 8622) & 52300 \\
\hline 0761535 & $49.33703-124.08223$ & start ramping guns & & \\
\hline 0790201 & $48.51474-122.74304$ & guns off, sea lion & SG1 (Line 6, FFID 4200) & 64200 \\
\hline$\underline{0790209}$ & $48.50583-122.74091$ & start ramping guns & & \\
\hline
\end{tabular}


TABLE 6. Origin Times (UTC), Locations, Depths, and Magnitudes of Earthquakes and Blasts in Western Washington and Southwestern British Columbia, March 7 to $25,1998^{1}$, written to archive tapes during our processing

\begin{tabular}{|c|c|c|c|c|c|c|c|c|c|}
\hline Event & & & Origin & & & Depth & & & \\
\hline No. & $\underline{\mathrm{JD}}$ & Date & $\underline{\text { Time }}$ & Lat. & Long. & $(\mathrm{km})$ & Mag. & Qual. & Comments \\
\hline 120001 & 066 & 03/07 & 05:20:02 & 47.4 & -122.76 & 22.2 & 0.7 & A & $21.5 \mathrm{~km} \mathrm{SSW}$ of Bremerton, WA \\
\hline 120002 & 068 & 03/09 & $03: 15: 27$ & 46.65 & -121.91 & 6.5 & 0.5 & B & $25.5 \mathrm{~km} \mathrm{SSW}$ of Mount Rainier \\
\hline 120003 & 068 & 03/09 & $23: 48: 49$ & 47.16 & -121.93 & 0.0 & 1.7 & A & Blast $4.5 \mathrm{~km} \mathrm{SE}$ of Enumclaw, WA \\
\hline 120004 & 069 & $03 / 10$ & $11: 36: 22$ & 47.5 & -122.00 & 15.7 & 1.1 & B & $11.2 \mathrm{~km}$ WSW of Fall City, WA \\
\hline 120005 & 069 & $03 / 10$ & $17: 16: 18$ & 46.9 & -121.55 & 8.9 & 0.3 & A & 16.8 km ENE of Mount Rainier \\
\hline 120006 & 069 & $03 / 10$ & 22:03:39 & 46.5 & -122.4 & 16.9 & 2.8 & B & $11.7 \mathrm{~km}$ WSW of Morton, WA \\
\hline 120007 & 070 & $03 / 11$ & $06: 31: 40$ & 46.75 & -121.9 & 9.1 & 1.0 & A & 15.4 km SW of Mount Rainier \\
\hline 120008 & 070 & $03 / 11$ & $08: 37: 23$ & 46.81 & -121.95 & 4.4 & 0.3 & A & $15.8 \mathrm{~km} \mathrm{~W}$ of Mount Rainier \\
\hline 120009 & 070 & $03 / 11$ & $14: 07: 41$ & 47.71 & -122.6 & 0.0 & 0.0 & $\mathrm{D}$ & $3.1 \mathrm{~km}$ ESE of Poulsbo, WA \\
\hline 120010 & 070 & $03 / 11$ & $16: 41: 41$ & 47.43 & -121.61 & 8.1 & 1.4 & $\mathrm{C}$ & $13.3 \mathrm{~km}$ ESE of North Bend, WA \\
\hline 120011 & 070 & $03 / 11$ & $20: 04: 23$ & 47.61 & -121.95 & 27.1 & 1.0 & A & $4.7 \mathrm{~km} \mathrm{SW}$ of Carnation, WA \\
\hline 120012 & 071 & $03 / 12$ & $18: 05: 27$ & 47.68 & -121.78 & 0.0 & 2.1 & $\mathrm{C}$ & 10.4 km ENE of Carnation, WA \\
\hline 120013 & 072 & $03 / 13$ & $11: 11: 41$ & 46.71 & -121.53 & 1.5 & 0.8 & B & $22.5 \mathrm{~km} \mathrm{SE}$ of Mount Rainier \\
\hline 120014 & 072 & $03 / 13$ & 20:19:19 & 48.78 & -121.75 & 22.2 & 2.7 & B & LOWF $4.5 \mathrm{~km}$ ENE of Mount Baker \\
\hline 120015 & 073 & $03 / 14$ & $21: 47: 41$ & 48.3 & -122.06 & 8.3 & 1.7 & B & $23.3 \mathrm{~km}$ ESE of Mount Vernon, WA \\
\hline 120016 & 073 & $03 / 14$ & $21: 50: 31$ & 48.3 & -122.08 & 9.8 & 1.4 & A & $22.4 \mathrm{~km} \mathrm{SE}$ of Mount Vernon, WA \\
\hline 120017 & 076 & $03 / 17$ & 01:58:11 & 48.48 & -121.76 & 12.9 & 1.3 & A & $5.7 \mathrm{~km} \mathrm{SSW}$ of Concrete, WA \\
\hline 120018 & 076 & $03 / 17$ & $06: 27: 58$ & 47.53 & -122.36 & 21.1 & 2.3 & A & $6.3 \mathrm{~km} \mathrm{SSW}$ of Seattle, WA \\
\hline 120019 & 076 & $03 / 17$ & 23:05:02 & 47.73 & -122.03 & 6.9 & 0.6 & B & $3.8 \mathrm{~km} \mathrm{~W}$ of Duvall, WA \\
\hline 120020 & 077 & $03 / 18$ & 01:41:06 & 48.73 & -121.5 & 1.7 & 1.0 & B & $23.2 \mathrm{~km} \mathrm{E}$ of Mount Baker \\
\hline 120021 & 077 & $03 / 18$ & 02:05:04 & 47.9 & -122.58 & 24.1 & 1.0 & B & $20.1 \mathrm{~km} \mathrm{~N}$ of Poulsbo, WA \\
\hline 120022 & 077 & $03 / 18$ & $13: 16: 30$ & 46.98 & -121.95 & 8.0 & 0.9 & A & 20.9 km NW of Mount Rainier \\
\hline 120023 & 078 & $03 / 19$ & 03:35:20 & 47.68 & -122.36 & 23.0 & 1.2 & B & $11.7 \mathrm{~km} \mathrm{NNW}$ of Seattle, WA \\
\hline 120024 & 078 & $03 / 19$ & $06: 27: 40$ & 46.53 & -121.75 & 0.7 & 1.1 & A & 23.8 km W of Goat Rocks \\
\hline 120025 & 079 & $03 / 20$ & 00:36:07 & 48.08 & -121.91 & 0.0 & 1.7 & B & Blast $3.3 \mathrm{~km}$ E of Granite Falls, WA \\
\hline 120026 & 079 & $03 / 20$ & 10:38:08 & 47.58 & -121.75 & 6.5 & 1.3 & A & $9.8 \mathrm{~km} \mathrm{~N}$ of North Bend, WA \\
\hline 120027 & 080 & $03 / 21$ & $00: 33: 40$ & 47.88 & -122.63 & 10.9 & 0.6 & B & $18.3 \mathrm{~km} \mathrm{~N}$ of Poulsbo, WA \\
\hline 120028 & 080 & $03 / 21$ & $22: 21: 42$ & 47.58 & -122.15 & 2.8 & 2.1 & A & $3.0 \mathrm{~km}$ ESE of Bellevue, WA \\
\hline 120029 & 081 & $03 / 22$ & $05: 20: 43$ & 47.66 & -121.81 & 11.0 & 1.6 & A & $7.3 \mathrm{~km}$ ENE of Carnation, WA \\
\hline 120030 & 081 & $03 / 22$ & $10: 52: 23$ & 46.85 & -121.95 & 9.1 & 0.7 & A & $15.2 \mathrm{~km} \mathrm{~W}$ of Mount Rainier \\
\hline 120031 & 081 & $03 / 22$ & $17: 59: 05$ & 46.63 & -122.35 & 18.6 & 1.3 & A & $11.5 \mathrm{~km}$ NNW of Morton, WA \\
\hline 120032 & 082 & $03 / 23$ & $11: 54: 36$ & 46.71 & -121.85 & 2.4 & 2.0 & B & 16.7 km SSW of Mount Rainier \\
\hline 120033 & 084 & $03 / 25$ & 0:36:09 & 47.86 & -122.7 & 0.0 & 1.1 & B & $16.2 \mathrm{~km}$ NNW of Poulsbo, WA \\
\hline 120034 & 084 & $03 / 25$ & $1: 15: 54$ & 48.08 & -121.9 & 0.0 & 1.7 & B & Blast $5.0 \mathrm{~km} \mathrm{E}$ of Granite Falls, WA \\
\hline 120035 & 084 & $03 / 25$ & $1: 54: 55$ & 48.03 & -122.25 & 17.4 & 1.7 & B & $7.2 \mathrm{~km} \mathrm{NNW}$ of Everett, WA \\
\hline 120036 & 084 & $03 / 25$ & $22: 21: 44$ & 46.76 & -122.81 & 2.0 & 3.3 & A & Blast $12.5 \mathrm{~km} \mathrm{NE}$ of Centralia, WA \\
\hline 120037 & 066 & 03/07 & $03: 29: 33$ & 49.79 & -123.63 & 4 & 1.3 & & Pacific Geoscience Centre Catalog \\
\hline 120038 & 067 & 03/08 & 05:20:59 & 49.70 & -123.59 & 4 & 1.5 & & \\
\hline
\end{tabular}




$\begin{array}{llllllrl}120039 & 067 & 03 / 08 & 06: 04: 41 & 48.76 & -128.32 & 10 & \\ 120040 & 068 & 03 / 09 & 01: 44: 11 & 48.92 & -123.43 & 4 & 0.8 \\ 120041 & 068 & 03 / 09 & 02: 05: 25 & 48.92 & -123.43 & 4 & 1.4 \\ 120042 & 068 & 03 / 09 & 02: 16: 31 & 48.92 & -123.43 & 4 & 0.5 \\ 120043 & 070 & 03 / 11 & 06: 17: 41 & 48.92 & -123.43 & 4 & 0.6 \\ 120044 & 070 & 03 / 11 & 22: 31: 55 & 49.79 & -123.62 & 4 & 1.1 \\ 120045 & 072 & 03 / 13 & 17: 36: 12 & 49.51 & -129.70 & 10 & \\ 120046 & 072 & 03 / 13 & 20: 19: 19 & 48.81 & -121.78 & 30 & 3.0 \\ 120047 & 074 & 03 / 15 & 02: 31: 17 & 50.23 & -129.64 & 10 & \\ 120048 & 074 & 03 / 15 & 12: 54: 50 & 49.73 & -126.96 & 31 & 1.5 \\ 120049 & 074 & 03 / 15 & 19: 36: 39 & 48.88 & -123.95 & 1 & 0.9 \\ 120050 & 076 & 03 / 17 & 01: 18: 54 & 49.35 & -121.28 & 10 \mathrm{~F} & 1.7 \\ 120051 & 076 & 03 / 17 & 04: 47: 54 & 48.86 & -129.18 & 10 & \\ 120052 & 076 & 03 / 17 & 05: 50: 24 & 48.64 & -122.99 & 1 & 0.7 \\ 120053 & 076 & 03 / 17 & 06: 07: 41 & 48.86 & -129.18 & 10 & \\ 120054 & 076 & 03 / 17 & 22: 13: 07 & 49.03 & -125.57 & 29 & 1.0 \\ 120055 & 077 & 03 / 18 & 01: 07: 49 & 50.19 & -127.74 & 22 & 0.5 \\ 120056 & 078 & 03 / 19 & 01: 43: 37 & 49.33 & -124.63 & 1 & 3.0 \\ 120057 & 078 & 03 / 19 & 14: 24: 09 & 48.63 & -122.99 & 0 \mathrm{~F} & 0.7 \\ 120058 & 078 & 03 / 19 & 16: 34: 55 & 49.24 & -123.62 & 3 & 1.8 \\ 120059 & 079 & 03 / 20 & 06: 03: 41 & 48.77 & -123.15 & 59 & 0.5 \\ 120060 & 083 & 03 / 24 & 19: 24: 41 & 50.01 & -127.89 & 24 & 1.3 \\ 120061 & 083 & 03 / 24 & 20: 17: 12 & 49.88 & -127.73 & 25 & 0.7 \\ 120062 & 084 & 03 / 25 & 15: 00: 31 & 48.99 & -129.17 & 10 & \end{array}$

${ }^{1}$ http://www.geophys.washington.edu/SEIS/PNSN/CATALOG_SEARCH/cat.search.html http://www.pgc.nrcan.gc.ca/seismo/recent/swbc.1yr.list.html 
Table 7. Reftek Receivers Deployed in Multiple Locations (Times in UTC)

$\begin{array}{rcccc}\text { Station } & \text { DAS } & \text { Start Time } & \text { End Time } & \text { Reftek } \\ \text { No. } & \text { No. } & \text { JD:HrMn } & \text { JD:HrMn } & \text { Line } \\ & & & & \text { No. } \\ & & & & \\ 9012 & 7466 & 068: 2232 & 071: 2240 & 1-2 \\ 9026 & 7466 & 074: 0015 & 083: 1721 & 4-11 \\ 11001 & 7337 & 073: 1729 & 075: 2136 & 3-5 \\ 11002 & 6116 & 073: 1637 & 075: 2041 & 3-5 \\ 11003 & 6126 & 073: 1535 & 083: 2006 & 3-11 \\ 11007 & 7301 & 069: & 071: 2304 & 1-2 \\ 11007 \text { A } & 7301 & 072: 0000 & 084: 1857 & 2-11 \\ 11010 & 6113 & 073: 1907 & 075: 1822 & 4-5 \\ 11011 & 6058 & 073: 2231 & 075: 1607 & 4-5 \\ 11013 & 6060 & 073: 2030 & 075: 1608 & 4-5 \\ 11023 & 7337 & 069: 0040 & 073: 0620 & 1-3 \\ 11025 & 6126 & 068: 2115 & 073: 0401 & 1-3 \\ 11025 & 6113 & 076: 0154 & 084: 0158 & 5-11 \\ 11026 & 6113 & 068: 1930 & 073: 0326 & 1-3 \\ 11026 & 7337 & 076: 0222 & 084: 0130 & 5-11 \\ 11027 & 6116 & 068: 1830 & 073: 0235 & 1-3 \\ 11027 & 6060 & 076: 0304 & 084: 0047 & 5-11 \\ 11028 & 6058 & 068: 1730 & 073: 0149 & 1-3 \\ 11028 & 6058 & 076: 0354 & 083: 2350 & 5-11 \\ 11029 & 6060 & 068: 1650 & 073: 0116 & 1-3 \\ 11029 & 6116 & 076: 0436 & 083: 1925 & 5-11 \\ 11034 & 7332 & 068: 1954 & 077: 1550 & 1-5 \\ 11035 & 7429 & 068: 0146 & 077: 1530 & 1-5 \\ 11036 & 7351 & 068: 0027 & 077: 0342 & 1-5 \\ 11037 & 7281 & 067: 2255 & 077: 0419 & 1-5 \\ 11038 & 7429 & 077: 1819 & 084: 1330 & 6-11 \\ 11039 & 7332 & 077: 1947 & 084: 0224 & 6-11 \\ 11041 & 7281 & 077: 1711 & 083: 2156 & 6-11 \\ 11042 & \underline{7351} & \underline{077: 1815} & \underline{083: 2246} & \underline{6-11}\end{array}$


Appendix 1. Abbreviated list of airgun shotpoint locations, FFID numbers, and shot times

\begin{tabular}{|c|c|c|c|c|c|}
\hline Lat. & Long. & $\begin{array}{c}\text { Thomp } \\
\text { son } \\
\text { FFID }\end{array}$ & $\begin{array}{l}\text { REF- } \\
\text { TEK } \\
\text { FFID }\end{array}$ & $\begin{array}{c}\text { Shottime } \\
(\mathrm{JD}, \mathrm{hr}, \mathrm{mn}, \mathrm{sc}) \\
\text { UTC }\end{array}$ & $\begin{array}{l}\text { Geo- } \\
\text { graphic } \\
\text { Location }\end{array}$ \\
\hline & & Line 1 & Line 1 & & \\
\hline 47.68904 & -122.24035 & 1 & 10001 & 69192420000 & Lake \\
\hline 47.69218 & -122.24487 & 10 & 10010 & 69193020000 & Washington \\
\hline 47.71537 & -122.27337 & 55 & 10055 & 69200020000 & \\
\hline 47.74020 & -122.26954 & 100 & 10100 & 69203020000 & \\
\hline 47.70795 & $\mid-122.26742$ & 145 & 10145 & 69210020000 & \\
\hline 47.68326 & -122.23185 & 190 & 10190 & 69213020000 & \\
\hline 47.65742 & -122.23138 & 235 & 10235 & 69220020000 & \\
\hline 47.66335 & -122.25640 & 280 & 10280 & 69223020000 & \\
\hline \multirow[t]{2}{*}{47.69295} & -122.24760 & 324 & 10324 & 69225940000 & \\
\hline & WA1 & Line 2 & Line 2 & & \\
\hline 47.71222 & -122.49091 & 1 & 20001 & 70100300000 & Puget Sound \\
\hline 47.68658 & -122.48261 & 42 & 20042 & 70103020000 & south bound \\
\hline 47.65192 & -122.47937 & 87 & 20087 & 70110020000 & \\
\hline 47.61397 & -122.47465 & 132 & 20132 & 70113020000 & \\
\hline 47.57779 & -122.46693 & 177 & 20177 & 70120020000 & \\
\hline 47.53782 & -122.46955 & 222 & 20222 & 70123020000 & \\
\hline 47.50203 & -122.49168 & 267 & 20267 & 70130020000 & \\
\hline 47.46687 & -122.51702 & 312 & 20312 & 70133020000 & \\
\hline 47.43098 & -122.52171 & 357 & 20357 & 70140020000 & \\
\hline 47.39766 & -122.53941 & 402 & 20402 & 70143020000 & \\
\hline 47.37044 & \begin{tabular}{|l|}
-122.53078 \\
\end{tabular} & 436 & 20436 & 70145300000 & \\
\hline 47.33972 & -122.54733 & 438 & 20438 & 70152100000 & \\
\hline 47.33171 & -122.55186 & 452 & 20452 & 70153020000 & \\
\hline 47.31023 & \begin{tabular}{|l|}
-122.55302 \\
\end{tabular} & 497 & 20497 & \begin{tabular}{|l|}
70160020000 \\
\end{tabular} & \\
\hline 47.28017 & -122.54463 & 542 & 20542 & 70163020000 & \\
\hline 47.24955 & -122.56683 & 587 & 20587 & 70170020000 & \\
\hline 47.21790 & -122.59200 & 632 & 20632 & \begin{tabular}{|l|}
70173020000 \\
\end{tabular} & \\
\hline \multirow[t]{2}{*}{47.21639} & -122.59306 & 634 & 20634 & 70173140000 & \\
\hline & WA1 & Line 3 & Line 2 & & \\
\hline 47.32109 & \begin{tabular}{|l|}
-122.72099 \\
\end{tabular} & 1 & 20635 & \begin{tabular}{|l|}
70192340000 \\
\end{tabular} & Carr Inlet \\
\hline 47.32550 & -122.71229 & 11 & 20645 & 70193020000 & \\
\hline 47.29185 & -122.71600 & 56 & 20690 & 70200020000 & \\
\hline 47.26041 & -122.69621 & 101 & 20735 & \begin{tabular}{|l|}
70203020000 \\
\end{tabular} & \\
\hline 47.23218 & -122.65662 & 146 & 20780 & 70210020000 & \\
\hline 47.20081 & -122.63345 & 191 & 20825 & 70213020000 & Puget Sound \\
\hline 47.16579 & -122.65164 & 236 & 20870 & \begin{tabular}{|l|}
70220020000 \\
\end{tabular} & southbound \\
\hline 47.13103 & $\mid-122.67446$ & 281 & 20915 & 70223020000 & (west side) \\
\hline 47.12209 & -122.72257 & 326 & 20960 & 70230020000 & \\
\hline 47.14783 & -122.76150 & 371 & 21005 & 70233020000 & \\
\hline 47.17664 & \begin{tabular}{|l|}
-122.79724 \\
\end{tabular} & 416 & 21050 & 71000020000 & \\
\hline 47.20953 & -122.82576 & 461 & 21095 & 71003020000 & \\
\hline 47.24566 & -122.84677 & 506 & 21140 & 71010020000 & \\
\hline 47.28194 & -122.85195 & 551 & 21185 & 71013020000 & \\
\hline 47.28960 & -122.81644 & 596 & 21230 & 71020020000 & South Puget \\
\hline 47.25878 & -122.85257 & 641 & 21275 & 71023020000 & Sound \\
\hline 47.22064 & -122.83201 & 686 & 21320 & \begin{tabular}{|l|}
71030020000 \\
\end{tabular} & \\
\hline 47.18473 & -122.80392 & 731 & 21365 & 71033020000 & \\
\hline
\end{tabular}

\begin{tabular}{|c|c|c|c|c|c|}
\hline 47.14946 & -122.77013 & 776 & 21410 & 71040020000 & \\
\hline 47.12032 & -122.72660 & 821 & 21455 & 71043020000 & \\
\hline 47.13220 & -122.67324 & 866 & 21500 & 71050020000 & Puget Sound \\
\hline 47.13753 & -122.66923 & 874 & 21508 & 71050540000 & northbound \\
\hline 47.20224 & -122.59628 & 875 & 21509 & 71064220000 & (east side) \\
\hline 47.22222 & -122.58411 & 902 & 21536 & 71070020000 & \\
\hline 47.25242 & -122.56594 & 947 & 21581 & 71073020000 & \\
\hline 47.27933 & -122.54335 & 992 & 21626 & 71080020000 & \\
\hline 47.30778 & -122.55549 & 1037 & 21671 & 71083020000 & \\
\hline 47.32764 & -122.53837 & 1082 & 21716 & 71090020000 & \\
\hline 47.30563 & -122.49864 & 1127 & 21761 & 71093020000 & \\
\hline 47.28019 & -122.45803 & 1172 & 21806 & 71100020000 & \\
\hline 47.29649 & -122.45046 & 1217 & 21851 & 71103020000 & \\
\hline 47.32557 & -122.43151 & 1262 & 21896 & 71110020000 & \\
\hline 47.34958 & -122.38928 & 1307 & 21941 & 71113020000 & \\
\hline 47.37396 & -122.34941 & 1352 & 21986 & 71120020000 & \\
\hline 47.40989 & -122.35928 & 1397 & 22031 & 71123020000 & \\
\hline 47.44392 & -122.38891 & 1442 & 22076 & 71130020000 & \\
\hline 47.48291 & -122.40236 & 1487 & 22121 & 71133020000 & \\
\hline 47.52160 & -122.41731 & 1532 & 22166 & 71140020000 & \\
\hline 47.56327 & -122.43106 & 1577 & 22211 & 71143020000 & \\
\hline 47.59947 & -122.40720 & 1622 & 22256 & 71150020000 & \\
\hline 47.60568 & -122.35752 & 1667 & 22301 & 71153020000 & \\
\hline 47.62403 & -122.40687 & 1712 & 22346 & 71160020000 & \\
\hline 47.64980 & -122.44314 & 1757 & 22391 & 71163020000 & \\
\hline 47.68797 & -122.44335 & 1802 & 22436 & 71170020000 & \\
\hline 47.72795 & -122.43323 & 1847 & 22481 & 71173020000 & \\
\hline 47.76892 & -122.41902 & 1892 & 22526 & 71180020000 & \\
\hline 47.80703 & -122.41154 & 1937 & 22571 & 71183020000 & \\
\hline 47.84066 & -122.39431 & 1982 & 22616 & 71190020000 & \\
\hline 47.87473 & -122.37766 & 2027 & 22661 & 71193020000 & \\
\hline 47.90734 & -122.35213 & 2072 & 22706 & 71200020000 & \\
\hline 47.94127 & -122.32288 & 2117 & 22751 & 71203020000 & \\
\hline 47.97325 & -122.29385 & 2162 & 22796 & 71210020000 & \\
\hline 48.00436 & -122.27670 & 2207 & 22841 & 71213020000 & \\
\hline 48.03547 & -122.30142 & 2252 & 22886 & 71220020000 & \\
\hline 48.06584 & -122.32637 & 2297 & 22931 & 71223020000 & \\
\hline 48.09590 & -122.35390 & 2342 & 22976 & 71230020000 & \\
\hline 48.12839 & -122.37457 & 2387 & 23021 & 71233020000 & \\
\hline \multirow[t]{2}{*}{48.14016} & -122.38592 & 2405 & 23039 & 71234220000 & \\
\hline & WA1 & Line 4 & Line 2 & & \\
\hline 48.05750 & -122.32801 & 1 & 23040 & 72012100000 & Saratoga \\
\hline 48.04813 & -122.32935 & 15 & 23054 & 72013020000 & Passage \\
\hline 48.04876 & -122.37394 & 60 & 23099 & 72020020000 & \\
\hline 48.06735 & -122.41795 & 105 & 23144 & 72023020000 & \\
\hline 48.09031 & -122.45460 & 150 & 23189 & 72030019998 & \\
\hline 48.10846 & -122.49290 & 195 & 23234 & 72033020000 & \\
\hline 48.13305 & -122.52891 & 240 & 23279 & 72040020000 & \\
\hline 48.16262 & -122.54650 & 285 & 23324 & 72043020000 & \\
\hline 48.19087 & -122.555 & 330 & 23369 & 72050020000 & \\
\hline 48.22205 & -122.55418 & 375 & 23414 & 72053019999 & \\
\hline \multirow[t]{2}{*}{48.24567} & -122.56949 & 419 & 23458 & 72055940000 & \\
\hline & WA1 & Line 5 & Line 3 & & \\
\hline 47.83027 & -122.3924 & 1 & 30001 & 72142740000 & Puget Sound \\
\hline
\end{tabular}




\begin{tabular}{|c|c|c|c|c|c|}
\hline 47.82829 & -122.39548 & 5 & 30006 & 72143020000 & NW bound \\
\hline 47.84344 & -122.42986 & 50 & 30051 & 72150020000 & \\
\hline 47.87626 & -122.45849 & 95 & 30096 & 72153020000 & \\
\hline 47.91467 & -122.47634 & 140 & 30141 & 72160020000 & \\
\hline 47.94788 & -122.52055 & 185 & 30186 & 72163020000 & \\
\hline 47.96178 & -122.58813 & 230 & 30231 & 72170020000 & Hood Canal \\
\hline 47.94548 & -122.62999 & 275 & 30276 & 72173020000 & south bound \\
\hline 47.91073 & -122.62084 & 320 & 30321 & 72180020000 & \\
\hline 47.87812 & $\mid-122.60304$ & 365 & 30366 & 72183020000 & \\
\hline 47.86718 & -122.61405 & 382 & 30383 & 72184140000 & \\
\hline 47.84683 & -122.64131 & 415 & 30384 & 72190340000 & \\
\hline 47.82558 & -122.67252 & 455 & 30424 & 72193020000 & \\
\hline 47.80243 & -122.70523 & 500 & 30469 & 72200020000 & \\
\hline 47.77625 & $|-122.72847|$ & 545 & 30514 & 72203020000 & \\
\hline 47.74792 & -122.74792 & 590 & 30559 & 72210020000 & \\
\hline 47.71616 & -122.76095 & 635 & 30604 & 72213020000 & \\
\hline 47.68323 & -122.76554 & 680 & 30649 & 72220020000 & \\
\hline 47.67177 & -122.80972 & 725 & 30694 & 72223020000 & \\
\hline 47.66141 & $\mid-122.85136$ & 770 & 30739 & 72230020000 & \\
\hline 47.6461 & -122.8916 & 815 & 30784 & 72233020000 & \\
\hline 47.62724 & -122.92822 & 860 & 30829 & 73000020000 & \\
\hline 47.60368 & -122.95592 & 905 & 30874 & 73003020000 & \\
\hline 47.57858 & -122.98396 & 950 & 30919 & 73010020000 & \\
\hline 47.55205 & -123.00862 & 995 & 30964 & 73013020000 & \\
\hline 47.52512 & $|-123.02966|$ & 1040 & 31009 & 73020020000 & \\
\hline 47.4933 & -123.04979 & 1085 & 31054 & 73023020000 & \\
\hline 47.46368 & -123.08136 & 1130 & 31099 & 73030020000 & \\
\hline 47.43147 & -123.10732 & 1175 & 31144 & 73033020000 & \\
\hline 47.39718 & -123.12743 & 1220 & 31189 & 73040020000 & \\
\hline 47.37253 & $\mid-123.12403$ & 1265 & 31234 & 73043020000 & Hood Canal \\
\hline 47.41092 & -123.1182 & 1310 & 31279 & 73050020000 & north bound \\
\hline 47.44709 & -123.09697 & 1355 & 31324 & 73053020000 & \\
\hline 47.48008 & -123.06731 & 1400 & 31369 & 73060020000 & \\
\hline 47.51329 & -123.03921 & 1445 & 31414 & 73063020000 & \\
\hline 47.54804 & $|-123.01241|$ & 1490 & 31459 & 73070020000 & \\
\hline 47.58249 & -122.98457 & 1535 & 31504 & 73073020000 & \\
\hline 47.61167 & -122.94987 & 1580 & 31549 & 73080020000 & \\
\hline 47.63415 & -122.91608 & 1625 & 31594 & 73083020000 & \\
\hline 47.65091 & -122.87517 & 1670 & 31639 & 73090020000 & \\
\hline 47.66685 & -122.83324 & 1715 & 31684 & 73093020000 & \\
\hline 47.67921 & $|-122.78521|$ & 1760 & 31729 & 73100020000 & \\
\hline 47.70408 & -122.75983 & 1805 & 31774 & 73103020000 & \\
\hline 47.74027 & -122.75201 & 1850 & 31819 & 73110020000 & \\
\hline 47.77525 & -122.73384 & 1895 & 31864 & 73113020000 & \\
\hline 47.80393 & -122.70034 & 1940 & 31909 & 73120020000 & \\
\hline 47.8268 & $\mid-122.66788$ & 1985 & 31954 & 73123020000 & \\
\hline 47.84718 & -122.63632 & 2027 & 31996 & 73125820000 & \\
\hline 47.86505 & -122.61721 & 2055 & 31997 & 73131700000 & \\
\hline 47.87739 & -122.60295 & 2075 & 32017 & 73133020000 & \\
\hline 47.90951 & -122.61639 & 2120 & 32062 & 73140020000 & \\
\hline 47.94404 & -122.6368 & 2165 & 32107 & 73143020000 & \\
\hline 47.98383 & $\mid-122.63406$ & 2210 & 32152 & 73150020000 & Puget Sound \\
\hline 48.02515 & -122.62649 & 2255 & 32197 & 73153020000 & NW bound \\
\hline 48.07198 & -122.62775 & 2300 & 32242 & 73160020000 & \\
\hline
\end{tabular}

\begin{tabular}{|c|c|c|c|c|c|}
\hline 48.11673 & -122.6523 & 2345 & 32287 & 73163020000 & \\
\hline 48.15843 & \begin{tabular}{|l|}
-122.71269 \\
\end{tabular} & 2390 & 32332 & 73170020000 & \\
\hline 48.19523 & -122.78185 & 2435 & 32377 & 73173020000 & \\
\hline \multirow[t]{2}{*}{48.20241} & \begin{tabular}{|l|}
-122.80287 \\
\end{tabular} & 2450 & 32392 & 73174020000 & \\
\hline & WA1 & Line 5 & Line 4 & & \\
\hline 48.20289 & -122.80423 & 2451 & 40001 & 73174100000 & Juan de \\
\hline 48.21627 & -122.84672 & 2480 & 40030 & 73180020000 & Fuca \\
\hline 48.25285 & -122.8872 & 2525 & 40050 & 73183020000 & westbound \\
\hline 48.28254 & $\mid-122.91308$ & 2567 & 40092 & 73190020000 & (northern \\
\hline 48.30904 & -122.94853 & 2612 & 40137 & 73193020000 & side) \\
\hline 48.31071 & -123.00722 & 2657 & 40182 & 73200020000 & \\
\hline 48.29679 & -123.0635 & 2702 & 40227 & \begin{tabular}{|l|}
73203020000 \\
\end{tabular} & \\
\hline 48.28077 & -123.11635 & 2747 & 40272 & 73210020000 & \\
\hline 48.25869 & $|-123.15963|$ & 2792 & 40317 & 73213020000 & \\
\hline 48.23862 & -123.20341 & 2837 & 40362 & 73220020000 & \\
\hline 48.21535 & -123.24399 & 2882 & 40407 & 73223020000 & \\
\hline 48.19239 & -123.28168 & 2927 & 40452 & 73230020000 & \\
\hline 48.16858 & \begin{tabular}{|l|}
-123.31622 \\
\end{tabular} & 2972 & 40497 & 73233020000 & \\
\hline 48.15557 & $|-123.34966|$ & 3017 & 40542 & 74000020000 & \\
\hline 48.18008 & -123.39074 & 3062 & 40587 & 74003020000 & \\
\hline 48.20676 & -123.43001 & 3107 & 40632 & 74010020000 & \\
\hline 48.22696 & -123.47487 & 3152 & 40677 & 74013020000 & \\
\hline 48.24704 & -123.52186 & 3197 & 40722 & 74020020000 & \\
\hline 48.2664 & -123.57766 & 3242 & 40767 & 74023020000 & \\
\hline 48.2794 & $|-123.63458|$ & 3287 & 40812 & 74030020000 & \\
\hline 48.29166 & \begin{tabular}{|l|}
-123.69842 \\
\end{tabular} & 3332 & 40857 & 74033020000 & \\
\hline 48.30679 & -123.75948 & 3377 & 40902 & 74040020000 & \\
\hline 48.31984 & -123.81759 & 3422 & 40947 & 74043020000 & \\
\hline 48.33184 & -123.87048 & 3467 & 40992 & 74050020000 & \\
\hline 48.34359 & $\mid-123.92428$ & 3512 & 41037 & 74053020000 & \\
\hline 48.35711 & \begin{tabular}{|l|}
-123.97979 \\
\end{tabular} & 3557 & 41082 & 74060020000 & \\
\hline 48.37169 & -124.03528 & 3602 & 41127 & 74063020000 & \\
\hline 48.38458 & -124.08977 & 3647 & 41172 & 74070020000 & \\
\hline 48.3969 & -124.14055 & 3692 & 41217 & 74073020000 & \\
\hline 48.40863 & $|-124.18868|$ & 3737 & 41262 & 74080020000 & \\
\hline 48.42028 & -124.23896 & 3782 & 41307 & 74083020000 & \\
\hline 48.43285 & -124.28827 & 3827 & 41352 & 74090020000 & \\
\hline 48.44522 & \begin{tabular}{|l|}
-124.33812 \\
\end{tabular} & 3872 & 41397 & 74093020000 & \\
\hline 48.45588 & -124.38624 & 3917 & 41442 & 74100020000 & \\
\hline 48.46806 & -124.43606 & 3962 & 41487 & 74103020000 & \\
\hline 48.48125 & $|-124.48536|$ & 4007 & 41532 & 74110020000 & \\
\hline 48.49358 & $-124.53557 \mid$ & 4052 & 41577 & 74113020000 & \\
\hline 48.50708 & -124.58817 & 4097 & 41622 & 74120020000 & \\
\hline 48.52131 & -124.6415 & 4142 & 41667 & 74123020000 & \\
\hline 48.5079 & -124.67342 & 4187 & 41712 & 74130020000 & \\
\hline 48.46777 & -124.6353 & 4232 & 41757 & 74133020000 & \\
\hline 48.43403 & -124.60583 & 4277 & 41802 & 74140020000 & \\
\hline 48.39894 & -124.57944 & 4322 & 41847 & 74143020000 & \\
\hline 48.38334 & -124.52599 & 4367 & 41892 & 74150020000 & \\
\hline 48.36743 & -124.47547 & 4412 & 41937 & \begin{tabular}{|l|}
74153020000 \\
\end{tabular} & \\
\hline 48.35324 & -124.4258 & 4457 & 41982 & 74160020000 & \\
\hline 48.33893 & |-124.37926 & 4502 & 42027 & 74163020000 & \\
\hline 48.32198 & -124.32938 & 4547 & 42072 & 74170020000 & \\
\hline 48.30667 & \begin{tabular}{|l|}
-124.27592 \\
\end{tabular} & 4592 & 42117 & 74173020000 & \\
\hline
\end{tabular}




\begin{tabular}{|c|c|c|c|c|c|}
\hline 48.29016 & -124.22753 & 4637 & 42162 & 74180020000 & \\
\hline 48.27474 & -124.17865 & 4682 & 42207 & 74183020000 & \\
\hline 48.25975 & -124.1261 & 4727 & 42252 & 74190020000 & \\
\hline 48.24197 & -124.07046 & 4772 & 42297 & 74193020000 & Juan de \\
\hline 48.22705 & -124.02242 & 4817 & 42342 & 74200020000 & Fuca \\
\hline 48.21099 & -123.97376 & 4862 & 42387 & 74203020000 & eastbound \\
\hline 48.20384 & -123.91872 & 4907 & 42432 & 74210020000 & (southern \\
\hline 48.2042 & -123.86409 & 4952 & 42477 & 74213020000 & side) \\
\hline 48.20399 & -123.80572 & 4997 & 42522 & 74220020000 & \\
\hline 48.20186 & -123.74982 & 5042 & 42567 & 74223020000 & \\
\hline 48.20074 & -123.68933 & 5087 & 42612 & 74230020000 & \\
\hline 48.20326 & -123.6334 & 5132 & 42657 & 74233020000 & \\
\hline 48.20156 & -123.57594 & 5177 & 42702 & 75000020000 & \\
\hline 48.19244 & -123.51698 & 5222 & 42747 & 75003020000 & \\
\hline 48.17759 & -123.46033 & 5267 & 42792 & 75010020000 & \\
\hline 48.17866 & -123.40798 & 5312 & 42837 & 75013020000 & \\
\hline 48.17353 & -123.35886 & 5357 & 42882 & 75020020000 & \\
\hline 48.15833 & -123.30821 & 5402 & 42927 & 75023020000 & \\
\hline 48.16416 & -123.25453 & 5447 & 42972 & 75030020000 & \\
\hline 48.18315 & -123.21085 & 5492 & 43017 & 75033020000 & \\
\hline 48.19866 & -123.16654 & 5537 & 43062 & 75040020000 & \\
\hline 48.19767 & -123.11379 & 5582 & 43107 & 75043020000 & \\
\hline 48.19719 & -123.06596 & 5627 & 43152 & 75050020000 & \\
\hline 48.16504 & -123.04231 & 5672 & 43197 & 75053020000 & \\
\hline 48.13483 & $|-123.02457|$ & 5717 & 43242 & 75060020000 & \\
\hline 48.11063 & -123.00015 & 5762 & 43287 & 75063020000 & \\
\hline 48.10698 & -122.95703 & 5807 & 43332 & 75070020000 & \\
\hline 48.11145 & \begin{tabular}{|l|}
-122.91489 \\
\end{tabular} & 5851 & 43376 & 75072940000 & \\
\hline 48.13202 & -122.8782 & 5893 & 43418 & 75080020000 & \\
\hline 48.15493 & $\mid-122.84219$ & 5938 & 43463 & 75083020000 & \\
\hline 48.18294 & \begin{tabular}{|l|}
-122.81961 \\
\end{tabular} & 5983 & 43508 & 75090020000 & \\
\hline 48.21563 & -122.80408 & 6028 & 43553 & 75093020000 & \\
\hline 48.24809 & -122.79145 & 6073 & 43598 & 75100020000 & \\
\hline \multirow[t]{2}{*}{48.25055} & \begin{tabular}{|l|}
-122.79037 \\
\end{tabular} & 6076 & 43601 & 75100220000 & \\
\hline & WA1 & Line 5 & Line 5 & & \\
\hline 48.25137 & -122.79005 & 6077 & 50001 & 75100300000 & San Juan \\
\hline 48.28309 & \begin{tabular}{|l|}
-122.77901 \\
\end{tabular} & 6118 & 50042 & 75103020000 & Islands \\
\hline 48.31721 & -122.76514 & 6163 & 50087 & 75110020000 & \\
\hline 48.35157 & \begin{tabular}{|l|}
-122.74814 \\
\end{tabular} & 6208 & 50132 & 75113020000 & \\
\hline 48.38655 & \begin{tabular}{|l|}
-122.73352 \\
\end{tabular} & 6253 & 50177 & 75120020000 & \\
\hline 48.424 & $\mid-122.72854$ & 6298 & 50222 & 75123020000 & \\
\hline 48.46648 & \begin{tabular}{|l|}
-122.72977 \\
\end{tabular} & 6343 & 50267 & 75130020000 & \\
\hline 48.50951 & $-122.73626 \mid$ & 6388 & 50312 & 75133020000 & \\
\hline 48.55508 & \begin{tabular}{|l|}
-122.74469 \\
\end{tabular} & 6433 & 50357 & 75140020000 & \\
\hline 48.60092 & \begin{tabular}{|l|}
-122.75427 \\
\end{tabular} & 6478 & 50402 & 75143020000 & \\
\hline 48.63846 & |-122.72891| & 6523 & 50447 & 75150020000 & \\
\hline 48.67423 & \begin{tabular}{|l|}
-122.70726 \\
\end{tabular} & 6568 & 50492 & 75153020000 & \\
\hline 48.70557 & \begin{tabular}{|l|}
-122.72797 \\
\end{tabular} & 6613 & 50537 & 75160020000 & \\
\hline 48.73943 & -122.74698 & 6658 & 50582 & 75163020000 & \\
\hline 48.76699 & \begin{tabular}{|l|}
-122.77368 \\
\end{tabular} & 6703 & 50627 & 75170020000 & Strait of \\
\hline 48.77551 & -122.82614 & 6748 & 50672 & 75173020000 & Georgia \\
\hline 48.79448 & -122.8712 & 6793 & 50717 & 75180020000 & (USA \\
\hline 48.81237 & \begin{tabular}{|l|}
-122.92049 \\
\end{tabular} & 6838 & 50762 & 75183020000 & waters) \\
\hline 48.82794 & -122.97224 & 6883 & 50807 & 75190020000 & \\
\hline
\end{tabular}

\begin{tabular}{|c|c|c|c|c|c|}
\hline 48.8427 & -123.02153 & 6928 & 50852 & 75193020000 & \\
\hline 48.85718 & -123.06998 & 6973 & 50897 & 75200020000 & \\
\hline 48.87186 & $|-123.11611|$ & 7018 & 50942 & 75203020000 & \\
\hline 48.88498 & -123.16339 & 7063 & 50987 & 75210020000 & \\
\hline 48.89801 & -123.20779 & 7108 & 51032 & 75213020000 & \\
\hline 48.91185 & -123.25172 & 7153 & 51077 & 75220020000 & \\
\hline 48.92353 & -123.29176 & 7198 & 51122 & 75223020000 & \\
\hline 48.93575 & -123.3322 & 7243 & 51167 & 75230020000 & \\
\hline 48.94777 & \begin{tabular}{|l|}
-123.37277 \\
\end{tabular} & 7288 & 51212 & 75233020000 & \\
\hline 48.95875 & -123.39355 & 7318 & 51242 & 75235020000 & \\
\hline 48.97225 & -123.3917 & 7565 & 51243 & 76023740000 & \\
\hline 48.99458 & -123.38614 & 7595 & 51273 & 76030020000 & \\
\hline 49.02616 & -123.3778 & 7640 & 51318 & 76033020000 & Strait of \\
\hline 49.06292 & \begin{tabular}{|l|}
-123.36829 \\
\end{tabular} & 7685 & 51363 & 76040020000 & Georgia \\
\hline 49.09527 & -123.3597 & 7730 & 51408 & 76043020000 & (Canadian \\
\hline 49.12851 & \begin{tabular}{|l|}
-123.35094 \\
\end{tabular} & 7775 & 51453 & 76050020000 & waters) \\
\hline 49.16178 & -123.34219 & 7820 & 51498 & 76053020000 & \\
\hline 49.19614 & -123.333 & 7865 & 51543 & 76060020000 & \\
\hline 49.23041 & $|-123.32362|$ & 7910 & 51588 & 76063020000 & \\
\hline 49.26603 & \begin{tabular}{|l|}
-123.31448 \\
\end{tabular} & 7955 & 51633 & 76070020000 & \\
\hline 49.2942 & -123.32191 & 8000 & 51678 & 76073020000 & \\
\hline 49.28407 & -123.3714 & 8045 & 51723 & 76080020000 & \\
\hline 49.28143 & -123.42142 & 8090 & 51768 & 76083020000 & \\
\hline 49.27888 & -123.47129 & 8135 & 51813 & 76090020000 & \\
\hline 49.2763 & -123.52121 & 8180 & 51858 & 76093020000 & \\
\hline 49.27364 & \begin{tabular}{|l|}
-123.57261 \\
\end{tabular} & 8225 & 51903 & 76100020000 & \\
\hline 49.27084 & -123.61874 & 8270 & 51948 & 76103020000 & \\
\hline 49.2683 & -123.66694 & 8315 & 51993 & 76110020000 & \\
\hline 49.2653 & \begin{tabular}{|l|}
-123.71831 \\
\end{tabular} & 8360 & 52038 & 76113020000 & \\
\hline 49.26291 & \begin{tabular}{|l|}
-123.76986 \\
\end{tabular} & 8405 & 52083 & 76120020000 & \\
\hline 49.26063 & -123.8197 & 8450 & 52128 & 76123020000 & \\
\hline 49.25698 & \begin{tabular}{|l|}
-123.86712 \\
\end{tabular} & 8495 & 52173 & 76130020000 & \\
\hline 49.25568 & -123.9185 & 8540 & 52218 & 76133020000 & \\
\hline 49.26637 & \begin{tabular}{|l|}
-123.96461 \\
\end{tabular} & 8585 & 52263 & 76140020000 & \\
\hline 49.28265 & $\mid-124.00047$ & 8622 & 52300 & 76142500000 & \\
\hline 49.33658 & -124.08187 & 8623 & 52301 & 76153540000 & \\
\hline 49.365 & -124.09016 & 8660 & 52338 & 76160020000 & \\
\hline 49.39945 & -124.09625 & 8705 & 52383 & 76163020000 & \\
\hline 49.43378 & -124.10098 & 8750 & 52428 & 76170020000 & \\
\hline 49.46658 & -124.10226 & 8795 & 52473 & 76173020000 & \\
\hline 49.49969 & -124.10163 & 8840 & 52518 & 76180020000 & \\
\hline 49.53359 & -124.1037 & 8885 & 52563 & 76183020000 & \\
\hline 49.56453 & -124.1276 & 8930 & 52608 & 76190020000 & \\
\hline 49.59229 & -124.16536 & 8975 & 52653 & 76193020000 & \\
\hline 49.62037 & \begin{tabular}{|l|}
-124.20489 \\
\end{tabular} & 9020 & 52698 & 76200020000 & \\
\hline 49.64602 & -124.24275 & 9065 & 52743 & 76203020000 & \\
\hline 49.67245 & -124.28155 & 9110 & 52788 & 76210020000 & \\
\hline 49.69896 & \begin{tabular}{|l|}
-124.32011 \\
\end{tabular} & 9155 & 52833 & 76213020000 & \\
\hline 49.72608 & \begin{tabular}{|l|}
-124.35786 \\
\end{tabular} & 9200 & 52878 & 76220020000 & \\
\hline 49.74102 & -124.41086 & 9245 & 52923 & 76223020000 & \\
\hline 49.75681 & \begin{tabular}{|l|}
-124.46377 \\
\end{tabular} & 9290 & 52968 & 76230020000 & \\
\hline 49.77584 & $\mid-124.51346$ & 9335 & 53013 & 76233020000 & \\
\hline 49.8046 & -124.55537 & 9380 & 53058 & 77000020000 & \\
\hline 49.83213 & -124.59669 & 9425 & 53103 & 77003020000 & \\
\hline
\end{tabular}




\begin{tabular}{|c|c|c|c|c|c|}
\hline 49.82284 & -124.65441 & 9470 & 53148 & 77010020000 & \\
\hline 49.79648 & -124.69035 & 9512 & 53190 & 77012820000 & \\
\hline & Line SG1 & & Line 6 & & \\
\hline 49.69897 & -124.71456 & 1 & 60001 & 78003345235 & Strait of \\
\hline 49.66993 & -124.68628 & 77 & 60077 & 78010002132 & Georgia \\
\hline 49.63956 & -124.65377 & 159 & 60159 & 78013011620 & (Canadian \\
\hline 49.60904 & -124.62278 & 240 & 60240 & 78020004186 & waters, \\
\hline 49.57827 & -124.5924 & 321 & 60321 & 78023012174 & western \\
\hline 49.54721 & $\mid-124.56141$ & 403 & 60403 & 78030008163 & passage) \\
\hline 49.51609 & -124.5306 & 485 & 60485 & 78033002151 & \\
\hline 49.48436 & -124.4988 & 569 & 60569 & 78040011765 & \\
\hline 49.459 & -124.46023 & 650 & 60650 & 78043017160 & \\
\hline 49.44485 & \begin{tabular}{|l|}
-124.41096 \\
\end{tabular} & 728 & 60728 & 78050014008 & \\
\hline 49.4326 & -124.35973 & 807 & 60807 & 78053018121 & \\
\hline 49.41958 & -124.30519 & 891 & 60891 & 78060002454 & \\
\hline 49.40627 & -124.24938 & 977 & 60977 & 78063021161 & \\
\hline 49.39482 & -124.20207 & 1050 & 61050 & 78070008462 & \\
\hline 49.38246 & -124.15009 & 1130 & 61130 & 78073003639 & \\
\hline 49.36894 & -124.09424 & 1216 & 61216 & 78080008065 & \\
\hline 49.35608 & -124.04035 & 1299 & 61299 & 78083011053 & \\
\hline 49.35562 & -123.98378 & 1381 & 61381 & 78090018167 & \\
\hline 49.35531 & -123.92718 & 1463 & 61463 & 78093003249 & \\
\hline 49.35555 & \begin{tabular}{|l|}
-123.86979 \\
\end{tabular} & 1546 & 61546 & 78100009721 & \\
\hline 49.35271 & -123.81306 & 1626 & 61626 & 78103019084 & \\
\hline 49.32148 & -123.78425 & 1709 & 61709 & 78110018025 & \\
\hline 49.28796 & \begin{tabular}{|l|}
-123.76125 \\
\end{tabular} & 1791 & 61791 & 78113018920 & \\
\hline 49.26146 & -123.72389 & 1871 & 61871 & 78120008924 & \\
\hline 49.23509 & -123.6841 & 1953 & 61953 & 78123014880 & \\
\hline 49.20575 & \begin{tabular}{|l|}
-123.65042 \\
\end{tabular} & 2035 & 62035 & 78130019869 & \\
\hline 49.18329 & $\mid-123.60854$ & 2114 & 62114 & 78133007153 & \\
\hline 49.15748 & -123.56619 & 2198 & 62198 & 78140019547 & \\
\hline 49.13027 & -123.52497 & 2283 & 62283 & 78143011941 & \\
\hline 49.10441 & -123.48563 & 2364 & 62364 & 78150021929 & \\
\hline 49.07834 & -123.44675 & 2445 & 62445 & 78153022105 & \\
\hline 49.05182 & -123.40658 & 2528 & 62528 & 78160018921 & \\
\hline 49.02407 & -123.36412 & 2614 & 62614 & 78163017893 & \\
\hline 48.99652 & -123.32352 & 2698 & 62698 & 78170017475 & Strait of \\
\hline 48.97039 & -123.28377 & 2780 & 62780 & 78173008885 & Georgia \\
\hline 48.94281 & -123.24229 & 2866 & 62866 & 78180010170 & (USA \\
\hline 48.9142 & -123.20043 & 2952 & 62952 & 78183008862 & waters) \\
\hline 48.88731 & -123.15728 & 3039 & 63039 & 78190002804 & \\
\hline 48.86862 & -123.10426 & 3120 & 63120 & 78193017385 & \\
\hline 48.84982 & -123.05204 & 3206 & 63206 & 78200010186 & \\
\hline 48.82986 & -122.99946 & 3295 & 63295 & 78203020268 & \\
\hline 48.80926 & -122.94958 & 3381 & 63381 & 78210007334 & \\
\hline 48.79046 & -122.89817 & 3467 & 63467 & 78213003963 & \\
\hline 48.77112 & -122.84652 & 3551 & 63551 & 78220013795 & \\
\hline 48.7528 & \begin{tabular}{|l|}
-122.79642 \\
\end{tabular} & 3634 & 63634 & 78223003799 & San Juan \\
\hline 48.72277 & -122.76305 & 3713 & 63713 & 78230002599 & Islands \\
\hline 48.68794 & \begin{tabular}{|l|}
-122.73701 \\
\end{tabular} & 3799 & 63799 & 78233013775 & \\
\hline 48.65355 & -122.71707 & 3882 & 63882 & 79000009778 & \\
\hline 48.62115 & $\mid-122.74575$ & 3966 & 63966 & 79003014032 & \\
\hline 48.58864 & -122.75907 & 4041 & 64041 & 79010020739 & \\
\hline 48.55334 & -122.74905 & 4121 & 64121 & 79013014711 & \\
\hline
\end{tabular}

\begin{tabular}{|c|c|c|c|c|c|}
\hline 48.51704 & \begin{tabular}{|l|}
-122.74337 \\
\end{tabular} & 4200 & 64200 & 79020003714 & \\
\hline 48.48269 & -122.74446 & 4277 & 64277 & 79023004734 & \\
\hline 48.44796 & -122.76452 & 4358 & 64358 & 79030021221 & \\
\hline 48.41695 & -122.78703 & 4435 & 64435 & 79033010693 & \\
\hline 48.39785 & \begin{tabular}{|l|}
-122.83232 \\
\end{tabular} & 4516 & 64516 & 79040005000 & Eastern \\
\hline 48.37993 & -122.88337 & 4602 & 64602 & 79043011001 & Strait of \\
\hline 48.3615 & -122.93136 & 4688 & 64688 & 79050016973 & Juan de \\
\hline 48.34244 & -122.98072 & 4773 & 64773 & 79053001977 & Fuca \\
\hline 48.32356 & |-123.02999 & 4859 & 64859 & 79060007950 & (westbound) \\
\hline 48.3042 & -123.07933 & 4945 & 64945 & 79063013942 & \\
\hline 48.28547 & -123.12752 & 5031 & 65031 & 79070019910 & \\
\hline 48.26619 & -123.17716 & 5116 & 65116 & \begin{tabular}{|l|}
79073004883 \\
\end{tabular} & \\
\hline 48.24725 & -123.22574 & 5201 & 65201 & 79080005828 & \\
\hline 48.22829 & $|-123.27377|$ & 5287 & 65287 & 79083011811 & \\
\hline \multirow[t]{2}{*}{48.21519} & \begin{tabular}{|l|}
-123.30749 \\
\end{tabular} & 5345 & 65345 & 79085029792 & \\
\hline & Line JDF1 & & Line 7 & & \\
\hline 48.21218 & \begin{tabular}{|l|}
-123.32856 \\
\end{tabular} & 1 & 70001 & 79090223781 & Strait of \\
\hline 48.22217 & -123.37826 & 80 & 70080 & 79093002771 & Juan de \\
\hline 48.23353 & $|-123.43237|$ & 166 & 70166 & 79100008742 & Fuca \\
\hline 48.24436 & -123.4873 & 252 & 70252 & 79103014723 & (westbound, \\
\hline 48.25625 & -123.54207 & 338 & 70338 & 79110020688 & northern \\
\hline 48.27302 & -123.59358 & 423 & 70423 & 79113005659 & side) \\
\hline 48.28835 & -123.64639 & 509 & 70509 & 79120013615 & \\
\hline 48.30211 & -123.6987 & 595 & 70595 & 79123019603 & \\
\hline 48.31515 & $|-123.74953|$ & 680 & 70680 & 79130004576 & \\
\hline 48.32751 & -123.80084 & 766 & 70766 & 79133010562 & \\
\hline 48.33989 & -123.85539 & 852 & 70852 & 79140016534 & \\
\hline 48.35192 & -123.90788 & 937 & 70937 & 79143001511 & \\
\hline 48.36387 & -123.9606 & 1023 & 71023 & 79150007479 & \\
\hline 48.37623 & $|-124.01563|$ & 1109 & 71109 & 79153013450 & \\
\hline 48.3886 & \begin{tabular}{|l|}
-124.07012 \\
\end{tabular} & 1195 & 71195 & 79160019437 & \\
\hline 48.40152 & -124.12293 & 1280 & 71280 & 79163004409 & \\
\hline 48.41522 & -124.17764 & 1366 & 71366 & 79170010402 & \\
\hline 48.42858 & -124.23385 & 1452 & 71452 & 79173016384 & \\
\hline 48.44213 & -124.2872 & 1537 & 71537 & 79180001356 & \\
\hline 48.45621 & -124.341 & 1623 & 71623 & 79183007328 & \\
\hline 48.47172 & -124.39753 & 1712 & 71712 & 79190013549 & \\
\hline 48.48688 & -124.45313 & 1802 & 71802 & 79193014943 & \\
\hline 48.50208 & -124.50866 & 1892 & 71892 & 79200016321 & \\
\hline 48.51707 & -124.56338 & 1982 & 71982 & 79203017700 & \\
\hline 48.53132 & $|-124.61676|$ & 2072 & 72072 & 79210019078 & \\
\hline \multirow[t]{2}{*}{48.53818} & -124.6414 & 2113 & 72113 & 79211359706 & \\
\hline & Line JDF2 & & Line 8 & & \\
\hline 48.40946 & -124.61335 & 1 & 80001 & 79234845607 & Strait of \\
\hline 48.40401 & -124.59885 & 34 & 80034 & 80000018597 & Juan de \\
\hline 48.39004 & $|-124.55512|$ & 119 & 80119 & 80003003600 & Fuca \\
\hline 48.37432 & -124.50563 & 205 & 80205 & 80010009607 & (eastbound, \\
\hline 48.35715 & -124.45151 & 291 & 80291 & 80013015614 & southern \\
\hline 48.33997 & -124.39753 & 376 & 80376 & 80020000620 & side) \\
\hline 48.322 & -124.34106 & 462 & 80462 & 80023006627 & \\
\hline 48.30342 & -124.28305 & 548 & 80548 & 80030012634 & \\
\hline 48.28444 & $\mid-124.22375$ & 634 & 80634 & 80033018640 & \\
\hline 48.26588 & -124.16536 & 719 & 80719 & 80040003647 & \\
\hline 48.24723 & -124.10773 & 805 & 80805 & 80043009654 & \\
\hline
\end{tabular}




\begin{tabular}{|c|c|c|c|c|c|}
\hline 48.22889 & -124.05032 & 891 & 80891 & 80050015662 & \\
\hline 48.21202 & -123.99793 & 976 & 80976 & 80053000669 & \\
\hline 48.20505 & -123.94173 & 1062 & 81062 & 80060006676 & \\
\hline 48.2001 & -123.88153 & 1148 & 81148 & 80063012683 & \\
\hline 48.19573 & -123.82568 & 1234 & 81234 & 80070018690 & \\
\hline 48.19143 & -123.77096 & 1319 & 81319 & 80073003697 & \\
\hline 48.18705 & -123.71686 & 1380 & 81380 & 80080009704 & \\
\hline 48.18293 & $-123.66461 \mid$ & 1466 & 81466 & 80083015711 & \\
\hline 48.17892 & $|-123.61749|$ & 1551 & 81551 & 80090000719 & \\
\hline 48.17994 & -123.56923 & 1637 & 81637 & 80093006726 & \\
\hline 48.18201 & -123.51496 & 1723 & 81723 & 80100012734 & \\
\hline 48.18354 & -123.46204 & 1809 & 81809 & 80103018741 & \\
\hline 48.18506 & -123.41554 & 1894 & 81894 & 80110003749 & \\
\hline 48.18677 & -123.36898 & 1980 & 81980 & 80113009756 & \\
\hline 48.18825 & -123.32304 & 2066 & 82066 & 80120015763 & \\
\hline 48.19032 & $|-123.26798|$ & 2151 & 82151 & 80123000771 & \\
\hline 48.19218 & -123.21052 & 2237 & 82237 & 80130006778 & \\
\hline 48.19435 & -123.15092 & 2323 & 82323 & 80133012786 & \\
\hline 48.19678 & -123.09075 & 2409 & 82409 & 80140018794 & \\
\hline 48.19607 & \begin{tabular}{|l|}
-123.03402 \\
\end{tabular} & 2494 & 82494 & 80143003801 & \\
\hline 48.19256 & \begin{tabular}{|l|}
-122.97729 \\
\end{tabular} & 2580 & 82580 & 80150009809 & \\
\hline 48.18994 & -122.91767 & 2666 & 82666 & 80153015817 & \\
\hline 48.18569 & \begin{tabular}{|l|}
-122.85292 \\
\end{tabular} & 2751 & 82751 & 80160000824 & \\
\hline 48.17175 & -122.78869 & 2837 & 82837 & 80163006832 & \\
\hline 48.14889 & -122.73802 & 2923 & 82923 & 80170012839 & \\
\hline 48.12239 & -122.6919 & 3009 & 83009 & 80173018846 & \\
\hline \multirow[t]{2}{*}{48.09156} & -122.66237 & 3092 & 83092 & 80175921853 & \\
\hline & Line PS 1 & & Line 9 & & \\
\hline 48.09027 & -122.66204 & 1 & 90001 & 80180024853 & Puget Sound \\
\hline 48.05277 & $|-122.65234|$ & 86 & 90086 & 80183009860 & southbound \\
\hline 48.01788 & -122.6351 & 172 & 90172 & 80190015867 & \\
\hline 47.98568 & -122.61515 & 257 & 90257 & 80193000874 & \\
\hline 47.95667 & -122.59349 & 343 & 90343 & 80200006880 & \\
\hline 47.9397 & -122.55818 & 429 & 90429 & 80203012887 & \\
\hline 47.92408 & $\mid-122.52354$ & 515 & 90515 & 80210018893 & \\
\hline 47.90297 & \begin{tabular}{|l|}
-122.49819 \\
\end{tabular} & 600 & 90600 & 80213003900 & \\
\hline 47.8715 & \begin{tabular}{|l|}
-122.48772 \\
\end{tabular} & 686 & 90686 & 80220009906 & \\
\hline 47.83811 & -122.47725 & 772 & 90772 & 80223015912 & \\
\hline 47.80502 & \begin{tabular}{|l|}
-122.46549 \\
\end{tabular} & 857 & 90857 & 80230000919 & \\
\hline 47.76928 & -122.45537 & 943 & 90943 & 80233006925 & \\
\hline 47.73223 & -122.45583 & 1029 & 91029 & 81000012932 & \\
\hline 47.6968 & -122.47002 & 1115 & 91115 & 81003018938 & \\
\hline 47.66246 & -122.4768 & 1200 & 91200 & 81010003945 & \\
\hline 47.62528 & -122.47355 & 1286 & 91286 & 81013009951 & \\
\hline 47.58587 & -122.46218 & 1372 & 91372 & 81020015958 & \\
\hline 47.54601 & $|-122.46021|$ & 1457 & 91457 & 81023000965 & \\
\hline 47.50949 & -122.48625 & 1543 & 91543 & 81030006972 & \\
\hline 47.47511 & \begin{tabular}{|l|}
-122.51051 \\
\end{tabular} & 1629 & 91629 & 81033012979 & \\
\hline 47.43845 & -122.52242 & 1715 & 91715 & 81040018985 & \\
\hline 47.40402 & -122.53633 & 1800 & 91800 & 81043003992 & \\
\hline 47.36718 & -122.53167 & 1886 & 91886 & 81050009999 & \\
\hline 47.32924 & |-122.54335| & 1972 & 91972 & 81053016005 & \\
\hline 47.31697 & -122.50246 & 2057 & 92057 & 81060001012 & \\
\hline 47.31883 & -122.4647 & 2112 & 92112 & 81061916016 & \\
\hline
\end{tabular}

\begin{tabular}{|c|c|c|c|c|c|}
\hline & Line PS2 & & Line 9 & & \\
\hline 47.321 & -122.44845 & 1 & 92113 & 81062739999 & Puget Sound \\
\hline 47.32172 & $|-122.44436|$ & 8 & 92120 & 81062959999 & northbound \\
\hline 47.34076 & -122.39783 & 97 & 92209 & 81065959999 & \\
\hline 47.37068 & -122.36923 & 186 & 92298 & \begin{tabular}{|l|}
81072959999 \\
\end{tabular} & \\
\hline 47.40828 & -122.35632 & 276 & 92388 & 81075959999 & \\
\hline 47.44228 & -122.38638 & 366 & 92478 & 81082959999 & \\
\hline 47.47731 & -122.40373 & 455 & 92567 & 81085959999 & \\
\hline 47.51519 & |-122.41567| & 545 & 92657 & 81092959999 & \\
\hline 47.55329 & -122.42664 & 634 & 92746 & 81095959999 & \\
\hline 47.59066 & -122.44134 & 724 & 92836 & 81102959999 & \\
\hline 47.62969 & -122.44772 & 814 & 92926 & 81110000000 & \\
\hline 47.66911 & -122.45049 & 904 & 93016 & 81112959999 & \\
\hline 47.70628 & $|-122.43835|$ & 994 & 93106 & 81115959999 & \\
\hline 47.74302 & -122.42768 & 1082 & 93194 & 81122959999 & \\
\hline \begin{tabular}{|l|}
47.7804 \\
\end{tabular} & -122.42822 & 1172 & 93284 & 81125959999 & \\
\hline 47.81778 & -122.44127 & 1261 & 93373 & 81132959999 & \\
\hline 47.85523 & -122.45349 & 1351 & 93463 & 81135959999 & \\
\hline 47.89253 & $|-122.46686|$ & 1440 & 93552 & 81142959999 & \\
\hline 47.92939 & -122.48171 & 1530 & 93642 & 81145959999 & \\
\hline 47.9497 & -122.52324 & 1620 & 93732 & 81152959999 & \\
\hline 47.96743 & -122.57235 & 1710 & 93822 & 81155959999 & \\
\hline 48.00206 & -122.59995 & 1800 & 93912 & 81163000000 & \\
\hline 48.03536 & -122.62463 & 1886 & 93998 & 81170006007 & \\
\hline 48.07321 & |-122.63461| & 1968 & 94080 & 81173004014 & \\
\hline 48.11112 & -122.64659 & 2051 & 94163 & 81180017021 & \\
\hline 48.1377 & -122.68359 & 2136 & 94248 & 81183002028 & \\
\hline 48.16215 & -122.72993 & 2222 & 94334 & 81190008035 & \\
\hline 48.18597 & \begin{tabular}{|l|} 
\\
\end{tabular} & 2308 & 94420 & 81193014041 & \\
\hline 48.20797 & |-122.82487| & 2394 & 94506 & 81200020048 & \\
\hline 48.23784 & -122.85981 & 2479 & 94591 & 81203005055 & \\
\hline \multirow[t]{2}{*}{48.24980} & \begin{tabular}{|l|}
-122.87169 \\
\end{tabular} & 2511 & 94623 & 81204117058 & \\
\hline & Line PS2 & & Line 10 & & \\
\hline 48.25017 & -122.87205 & 2512 & 100001 & 81204138058 & Eastern \\
\hline 48.27028 & |-122.88999 & 2565 & 100054 & 81210011062 & Strait of \\
\hline 48.30302 & -122.91952 & 2651 & 100140 & 81213017069 & Juan de \\
\hline 48.3353 & -122.94925 & 2736 & 100225 & 81220002076 & Fuca \\
\hline 48.36746 & \begin{tabular}{|l|}
-122.97909 \\
\end{tabular} & 2822 & 100311 & 81223008083 & \\
\hline 48.40095 & $-123.00857 \mid$ & 2908 & 100397 & 81230014090 & \\
\hline 48.42964 & -123.046 & 2994 & 100483 & 81233020097 & \\
\hline 48.45494 & |-123.08387| & 3079 & 100568 & 82000005104 & \\
\hline 48.47879 & -123.118 & 3165 & 100654 & 82003011111 & \\
\hline 48.4958 & -123.14487 & 3250 & 100739 & 82010017118 & \\
\hline 48.51316 & -123.17028 & 3332 & 100821 & 82013021125 & \\
\hline 48.52884 & -123.19905 & 3413 & 100902 & 82020003132 & \\
\hline 48.51262 & $\mid-123.24835$ & 3495 & 100984 & 82023007139 & \\
\hline 48.47556 & -123.24219 & 3577 & 101066 & 82030011146 & \\
\hline 48.44617 & -123.21397 & 3659 & 101148 & 82033015153 & \\
\hline 48.41667 & -123.18044 & 3741 & 101230 & 82040019160 & \\
\hline 48.3887 & -123.15224 & 3822 & 101311 & 82043001167 & \\
\hline 48.36955 & -123.11131 & 3904 & 101393 & 82050005174 & \\
\hline 48.38443 & $|-123.05923|$ & 3986 & 101475 & 82053009181 & \\
\hline 48.38864 & -123.00281 & 4068 & 101557 & 82060013187 & \\
\hline 48.38942 & $\mid-122.94863$ & 4150 & 101639 & 82063017193 & \\
\hline
\end{tabular}




\begin{tabular}{|r|r|r|r|l|l|}
\hline 48.39038 & -122.88877 & 4232 & 101721 & 82070021199 & \\
\hline 48.39128 & -122.83249 & 4313 & 101802 & 82073003206 & \\
\hline 48.37194 & -122.79001 & 4395 & 101884 & 82080007212 & \\
\hline 48.33486 & -122.78346 & 4477 & 101966 & 82083011219 & \\
\hline 48.29662 & -122.78993 & 4559 & 102048 & 82090015225 & \\
\hline 48.25876 & -122.79524 & 4641 & 102130 & 82093019232 & \\
\hline 48.22229 & -122.80178 & 4722 & 102211 & 82100001239 & \\
\hline 48.1854 & -122.80819 & 4804 & 102293 & 82103005245 & \\
\hline 48.15559 & -122.84388 & 4886 & 102375 & 82110009252 & \\
\hline 48.1283 & -122.87567 & 4964 & 102453 & 82112845258 & \\
\hline & Line JDF3 & & Line 11 & & \\
\hline 48.11738 & -122.88991 & 1 & 110001 & 82114029261 & Eastern \\
\hline 48.10782 & -122.92378 & 55 & 110055 & 82120017265 & Strait of \\
\hline 48.10797 & -122.98325 & 137 & 110137 & 82123021271 & Juan de \\
\hline 48.13083 & -123.02447 & 218 & 110218 & 82130003277 & Fuca \\
\hline 48.17046 & -123.01927 & 300 & 110300 & 82133007283 & \\
\hline 48.21218 & -123.01341 & 382 & 110382 & 82140011290 & \\
\hline 48.25156 & -123.01347 & 464 & 110464 & 82143015296 & \\
\hline 48.29023 & -123.01429 & 546 & 110546 & 82150019302 & \\
\hline 48.32838 & -123.01485 & 627 & 110627 & 82153001309 & \\
\hline 48.36713 & -123.01599 & 709 & 110709 & 82160005315 & \\
\hline 48.40532 & -123.01664 & 791 & 110791 & 82163009323 & \\
\hline 48.43284 & -123.05157 & 873 & 110873 & 82170013330 & \\
\hline 48.42344 & -123.10721 & 955 & 110955 & 82173017336 & \\
\hline 48.41168 & -123.12512 & 993 & 110993 & 82174413339 & \\
\hline & Line JDF4 & & Line 11 & & \\
\hline 48.41092 & -123.12584 & 1 & 110994 & 82174457339 & Eastern \\
\hline 48.39457 & -123.141 & 43 & 111036 & 82180021342 & Strait of \\
\hline & & & & & \\
\hline
\end{tabular}

\begin{tabular}{|r|r|r|r|l|l|}
\hline 48.36316 & -123.17122 & 124 & 111117 & 82183003349 & Juan de \\
\hline 48.33041 & -123.20312 & 206 & 111199 & 82190007354 & Fuca \\
\hline 48.29741 & -123.2352 & 288 & 111281 & 82193011361 & \\
\hline 48.26637 & -123.26501 & 370 & 111363 & 82200015368 & \\
\hline 48.23533 & -123.29484 & 452 & 111445 & 82203019375 & \\
\hline 48.20888 & -123.33272 & 533 & 111526 & 82210001382 & \\
\hline 48.17495 & -123.332 & 615 & 111608 & 82213004388 & \\
\hline 48.17277 & -123.28117 & 697 & 111690 & 82220009395 & \\
\hline 48.18325 & -123.26725 & 734 & 111727 & 82221343398 & \\
\hline & Line JDF5 & & Line 11 & & \\
\hline 48.1847 & -123.26588 & 1 & 111728 & 82221520000 & Eastern \\
\hline 48.19664 & -123.25258 & 44 & 111771 & 82222959999 & Strait of \\
\hline 48.22286 & -123.22574 & 133 & 111860 & 82225959999 & Juan de \\
\hline 48.24763 & -123.20072 & 222 & 111949 & 82232959999 & Fuca \\
\hline 48.27288 & -123.17409 & 312 & 112039 & 82235959999 & \\
\hline 48.30184 & -123.14575 & 400 & 112127 & 83002959999 & \\
\hline 48.33187 & -123.11669 & 490 & 112217 & 83005959999 & \\
\hline 48.36074 & -123.08878 & 580 & 112307 & 83012959999 & \\
\hline 48.3914 & -123.05858 & 670 & 112397 & 83015959999 & \\
\hline 48.40332 & -123.02171 & 739 & 112466 & 83022259999 & \\
\hline & Line JDF6 & & Line 11 & & \\
\hline 48.40321 & -123.02 & 1 & 112467 & 83022359999 & Eastern \\
\hline 48.40102 & -123.01051 & 19 & 112485 & 83022959999 & Strait of \\
\hline 48.36713 & -123.00369 & 107 & 112573 & 83025959999 & Juan de \\
\hline 48.33267 & -123.01115 & 197 & 112663 & 83032959999 & Fuca \\
\hline 48.31337 & -123.01163 & 245 & 112711 & 83034559999 & \\
\hline & & & & & \\
\hline
\end{tabular}


Appendix 2. Reftek and OBS station locations and elevations

\begin{tabular}{|r|r|r|r|r|}
\hline $\begin{array}{r}\text { Station } \\
\text { Name }\end{array}$ & $\begin{array}{c}\text { DAS } \\
\text { No. }\end{array}$ & $\begin{array}{c}\text { Reftek } \\
\text { GPS } \\
\text { Latitude }\end{array}$ & $\begin{array}{c}\text { Reftek } \\
\text { GPS } \\
\text { Longitude }\end{array}$ & $\begin{array}{c}\text { Topo } \\
\text { map } \\
\text { elev } \\
(\mathrm{m})\end{array}$ \\
\hline & & & & \\
\hline 1002 & 6095 & 48.90531 & -122.76530 & 7 \\
\hline 1003 & 6041 & 48.82119 & -122.68182 & 54 \\
\hline$\bullet 1004$ & 7278 & 48.74074 & -122.70870 & 66 \\
\hline 1005 & 7447 & 48.68605 & -122.64225 & 64 \\
\hline 1006 & 6035 & 48.65071 & -122.49103 & 44 \\
\hline 1007 & 7111 & 48.57740 & -122.55620 & 10 \\
\hline 1007 & 6097 & 48.57740 & -122.55620 & 10 \\
\hline$\bullet 1008$ & 550 & 48.51381 & -122.59857 & 53 \\
\hline 1009 & 7097 & 48.46125 & -122.62924 & 210 \\
\hline 1009 & 6062 & 48.46125 & -122.62924 & 210 \\
\hline$\Delta 1010$ & 7059 & 48.39422 & -122.62177 & 72 \\
\hline$\bullet \Delta 1011$ & 7602 & 48.32825 & -122.61927 & 30 \\
\hline$\Delta 1012$ & 6056 & 48.27197 & -122.68263 & 39 \\
\hline$\Delta 1013$ & 6121 & 48.21907 & -122.63097 & 11 \\
\hline$\bullet 1014$ & 7298 & 48.17365 & -122.60353 & 94 \\
\hline$\Delta 1015$ & 6086 & 48.12120 & -122.57480 & 111 \\
\hline$\Delta 1016$ & 7069 & 48.06512 & -122.57518 & 134 \\
\hline$\bullet 1017$ & 7285 & 48.01509 & -122.55997 & 61 \\
\hline$\Delta 1018$ & 7083 & 47.96957 & -122.43875 & 30 \\
\hline$\bullet 1019$ & 7289 & 47.92208 & -122.41042 & 41 \\
\hline$\bullet 1020$ & 7286 & 48.66294 & -122.94756 & 42 \\
\hline 1021 & 7357 & 48.55026 & -122.87657 & 23 \\
\hline 1022 & 7345 & 48.43231 & -122.86050 & 12 \\
\hline$\bullet 2001$ & 153 & 47.90831 & -122.53122 & 6 \\
\hline 2002 & 6032 & 47.87833 & -122.60722 & 112 \\
\hline$\Delta 2003$ & 6021 & 47.84944 & -122.53889 & 90 \\
\hline 2004 & 7593 & 47.81583 & -122.53806 & 41 \\
\hline 2004 & 6091 & 47.81583 & -122.53806 & 41 \\
\hline$\bullet 2004$ & 6088 & 47.81583 & -122.53806 & 41 \\
\hline$\Delta 2005$ & 6047 & 47.79280 & -122.53995 & 27 \\
\hline$\bullet 2006$ & 7300 & 47.75610 & -122.47481 & 0 \\
\hline$\Delta 2007$ & 6122 & 47.74722 & -122.56194 & 13 \\
\hline$\Delta 2008$ & 6093 & 47.71722 & -122.54983 & 39 \\
\hline & & & & \\
\hline
\end{tabular}

\begin{tabular}{|r|r|r|r|r|}
\hline 2009 & 6031 & 47.79516 & -122.66198 & 104 \\
\hline 2010 & 6087 & 47.66626 & -122.62344 & 87 \\
\hline$\bullet 2011$ & 359 & 47.67500 & -122.54159 & 23 \\
\hline$\bullet 2012$ & 149 & 47.63114 & -122.53383 & 32 \\
\hline 2012 & 6064 & 47.63114 & -122.53383 & 32 \\
\hline$\bullet 2013$ & 340 & 47.61271 & -122.60715 & 96 \\
\hline 2014 & 6071 & 47.70000 & -122.68056 & 58 \\
\hline 3001 & 6057 & 47.58250 & -122.55615 & 30 \\
\hline$\bullet 3002$ & 529 & 47.54794 & -122.59029 & 92 \\
\hline 3003 & 6081 & 47.54934 & -122.55049 & 68 \\
\hline 3004 & 6125 & 47.51598 & -122.53207 & 67 \\
\hline$\Delta 3005$ & 7044 & 47.49750 & -122.51250 & 77 \\
\hline$\bullet 3006$ & 880 & 47.47698 & -122.54888 & 128 \\
\hline$\Delta 3007$ & 7064 & 47.44733 & -122.58167 & 38 \\
\hline$\Delta 3008$ & 7058 & 47.41483 & -122.55367 & 73 \\
\hline$\bullet 3009$ & 348 & 47.39031 & -122.56419 & 91 \\
\hline$\Delta 3010$ & 7081 & 47.36250 & -122.57717 & 27 \\
\hline 3011 & 6045 & 47.31861 & -122.59753 & 81 \\
\hline$\bullet 3012$ & 7283 & 47.29096 & -122.62180 & 58 \\
\hline$\bullet 3013$ & 7362 & 47.25799 & -122.63843 & 36 \\
\hline$\bullet 3014$ & 7597 & 47.22738 & -122.60925 & 99 \\
\hline$\bullet 4001$ & 898 & 47.75100 & -122.70327 & 99 \\
\hline 4002 & 7066 & 47.69337 & -122.73305 & 102 \\
\hline$\bullet 4003$ & 7288 & 47.64841 & -122.78774 & 56 \\
\hline 4004 & 7078 & 47.61771 & -122.89439 & 94 \\
\hline 4004 & 6066 & 47.61771 & -122.89439 & 94 \\
\hline 4005 & 7100 & 47.58407 & -122.93298 & 101 \\
\hline 4006 & 7112 & 47.55660 & -122.88785 & 159 \\
\hline 4006 & 6120 & 47.55660 & -122.88785 & 159 \\
\hline$\bullet 4007$ & 7282 & 47.55361 & -122.97433 & 136 \\
\hline 4008 & 7063 & 47.59469 & -122.75805 & 137 \\
\hline 4009 & 7110 & 47.48830 & -122.90544 & 110 \\
\hline 4010 & 6020 & 47.48582 & -123.01287 & 70 \\
\hline 4011 & 6108 & 47.43981 & -123.05902 & 125 \\
\hline 4012 & 6037 & 47.42026 & -122.95088 & 137 \\
\hline 4013 & 6085 & 47.42113 & -123.08682 & 147 \\
\hline$\Delta 5001$ & 7107 & 47.36717 & -122.85033 & 71 \\
\hline$\bullet 5002$ & 895 & 47.31109 & -122.92594 & 55 \\
\hline$\bullet 5003$ & 395 & 47.47459 & -122.73159 & 122 \\
\hline 5004 & 6025 & 47.38922 & -122.73923 & 73 \\
\hline$\Delta 5005$ & 7077 & 47.25733 & -122.74800 & 23 \\
\hline$\Delta 5006$ & 7039 & 47.22700 & -122.75200 & 12 \\
\hline & & & & \\
\hline
\end{tabular}




\begin{tabular}{|r|r|r|r|r|}
\hline$\bullet 5007$ & 877 & 47.24915 & -122.82293 & 72 \\
\hline$\bullet 5008$ & 369 & 47.17546 & -122.75692 & 57 \\
\hline$\bullet 5009$ & 656 & 47.39099 & -122.39513 & 122 \\
\hline$\bullet 6001$ & 7291 & 47.90120 & -122.67049 & 158 \\
\hline$\Delta 6002$ & 6084 & 47.92200 & -122.81750 & 120 \\
\hline 6003 & 6080 & 47.88639 & -123.02847 & 925 \\
\hline$\bullet 6004$ & 7595 & 47.84326 & -122.71887 & 134 \\
\hline$\Delta 6005$ & 6051 & 47.80250 & -122.77167 & 126 \\
\hline$\Delta 6006$ & 6098 & 47.75183 & -122.78683 & 121 \\
\hline 6007 & 7448 & 47.73744 & -123.16681 & 492 \\
\hline 6008 & 7444 & 47.73958 & -123.07108 & 185 \\
\hline$\bullet 6009$ & 7605 & 47.73029 & -123.12343 & 377 \\
\hline 6010 & 6003 & 47.72260 & -122.99782 & 116 \\
\hline 6010 & 6114 & 47.72260 & -122.99782 & 116 \\
\hline$\bullet 6011$ & 7615 & 47.71146 & -122.92585 & 154 \\
\hline$\bullet 6012$ & 7594 & 47.70990 & -122.82293 & 52 \\
\hline$\Delta 6013$ & 6019 & 47.69350 & -122.77867 & 85 \\
\hline$\Delta 6014$ & 6067 & 47.68833 & -122.90317 & 2 \\
\hline 7001 & 7056 & 47.50570 & -123.31528 & 242 \\
\hline 7002 & 7604 & 47.49454 & -123.24184 & 275 \\
\hline 7003 & 7052 & 47.45156 & -123.20860 & 295 \\
\hline 7004 & 7306 & 47.40793 & -123.15837 & 54 \\
\hline 7005 & 6090 & 47.35248 & -123.08809 & 72 \\
\hline 7006 & 7070 & 47.34062 & -123.02668 & 154 \\
\hline 7006 & 6102 & 47.34062 & -123.02668 & 154 \\
\hline 7007 & 6042 & 47.31966 & -123.12363 & 125 \\
\hline 7008 & 7292 & 47.28107 & -123.15098 & 84 \\
\hline$\bullet 7009$ & 381 & 47.23547 & -123.20967 & 76 \\
\hline$\bullet 7010$ & 7316 & 47.23655 & -122.99754 & 60 \\
\hline 7011 & 7085 & 47.21057 & -123.24407 & 70 \\
\hline 7012 & 7592 & 47.09431 & -123.04005 & 44 \\
\hline 7012 & 6107 & 47.09431 & -123.04005 & 44 \\
\hline 8001 & 6092 & 47.17125 & -122.82019 & 32 \\
\hline 8002 & 6040 & 47.12037 & -122.87655 & 37 \\
\hline$\bullet 8003$ & 7614 & 47.10356 & -122.73843 & 33 \\
\hline 8004 & 6101 & 47.08301 & -122.77955 & 81 \\
\hline 8005 & 6118 & 47.02664 & -122.78467 & 48 \\
\hline$\bullet 8006$ & 7303 & 46.96839 & -122.85793 & 57 \\
\hline 8007 & 6065 & 46.92920 & -122.96770 & 55 \\
\hline 8008 & 7330 & 46.88895 & -123.00933 & 52 \\
\hline$\bullet 8009$ & 7630 & 46.82657 & -123.06417 & 48 \\
\hline 8010 & 7320 & 46.78954 & -123.13044 & 114 \\
\hline 8011 & 7460 & 46.73608 & -123.20089 & 73 \\
\hline
\end{tabular}

\begin{tabular}{|r|r|r|r|r|}
\hline$\bullet 8012$ & 7295 & 46.69334 & -123.21161 & 108 \\
\hline 8013 & 7462 & 46.63818 & -123.27519 & 98 \\
\hline 8014 & 7440 & 46.58854 & -123.29948 & 159 \\
\hline 9001 & 7104 & 48.10256 & -122.69603 & 37 \\
\hline 9002 & 7046 & 48.02084 & -122.69337 & 35 \\
\hline 9003 & 6028 & 48.13702 & -122.76747 & 50 \\
\hline 9004 & 7099 & 48.08057 & -122.87965 & 102 \\
\hline 9004 & 6018 & 48.08057 & -122.87965 & 102 \\
\hline 9005 & 6046 & 48.01858 & -122.80665 & 92 \\
\hline$\bullet 9006$ & 7598 & 48.06772 & -122.95655 & 76 \\
\hline 9007 & 7092 & 48.02455 & -123.07024 & 526 \\
\hline$\bullet 9008$ & 7072 & 48.11804 & -123.08073 & 9 \\
\hline 9009 & 7116 & 48.04403 & -123.22399 & 338 \\
\hline$\bullet 9010$ & 7038 & 48.07383 & -123.43074 & 318 \\
\hline$\bullet 9011$ & 7428 & 48.01442 & -123.37468 & 783 \\
\hline 9012 & 7466 & 48.04549 & -123.58785 & 157 \\
\hline$\bullet 9012$ & 227 & 48.04541 & -123.58761 & 157 \\
\hline 9012 & 6069 & 48.04541 & -123.58761 & 157 \\
\hline 9012 & 6030 & 48.04541 & -123.58761 & 157 \\
\hline 9013 & 7324 & 47.98313 & -123.62507 & 537 \\
\hline$\bullet 9014$ & 7296 & 48.15068 & -123.66639 & 277 \\
\hline 9015 & 7098 & 48.08301 & -123.69480 & 397 \\
\hline 9016 & 7061 & 48.10898 & -123.79098 & 291 \\
\hline 9017 & 7452 & 48.15132 & -123.88121 & 178 \\
\hline$\bullet 9018$ & 7302 & 48.09739 & -123.95508 & 721 \\
\hline 9019 & 7454 & 48.17031 & -124.11473 & 151 \\
\hline 9021 & 7352 & 48.23669 & -124.23487 & 187 \\
\hline 9022 & 7435 & 48.26467 & -124.36379 & 161 \\
\hline$\bullet 9023$ & 338 & 48.31059 & -124.47501 & 241 \\
\hline 9024 & 7317 & 48.35624 & -124.55875 & 72 \\
\hline 9025 & 7089 & 48.37861 & -124.59513 & 12 \\
\hline 9026 & 7466 & 48.35312 & -124.66331 & 138 \\
\hline 9027 & 7339 & 48.10491 & -124.22802 & 511 \\
\hline 9028 & 7073 & 48.03434 & -123.97658 & 619 \\
\hline$\bullet 9029$ & 771 & 47.98776 & -123.94732 & 577 \\
\hline 9030 & 7075 & 47.95154 & -123.07359 & 726 \\
\hline 9030 & 6029 & 47.95154 & -123.07359 & 726 \\
\hline 9031 & 6026 & 47.78516 & -122.95995 & 488 \\
\hline 10001 & 7041 & 48.13589 & -122.28318 & 127 \\
\hline 10002 & 7114 & 48.14494 & -122.03767 & 47 \\
\hline 10003 & 7334 & 48.13327 & -121.84234 & 564 \\
\hline$\bullet 10004$ & 7627 & 48.05236 & -122.23341 & 89 \\
\hline 10005 & 7074 & 48.04871 & -122.03270 & 67 \\
\hline$\bullet 10006$ & 556 & 48.04495 & -121.84704 & 529 \\
\hline & & & & \\
\hline
\end{tabular}




\begin{tabular}{|r|r|r|r|r|}
\hline 10007 & 7364 & 48.06790 & -121.61598 & 418 \\
\hline 10008 & 7047 & 47.94643 & -122.27877 & 113 \\
\hline 10009 & 7040 & 47.94969 & -122.10789 & 98 \\
\hline$\bullet 10010$ & 7629 & 47.95012 & -121.88737 & 139 \\
\hline 10011 & 7043 & 47.94859 & -121.67681 & 500 \\
\hline$\bullet 10012$ & 7591 & 47.87189 & -122.29232 & 165 \\
\hline 10013 & 7082 & 47.86871 & -122.09487 & 58 \\
\hline$\bullet 10014$ & 7341 & 47.87789 & -121.90167 & 96 \\
\hline 10015 & 7091 & 47.86693 & -121.69991 & 51 \\
\hline 10016 & 7093 & 47.83102 & -122.29529 & 139 \\
\hline 10017 & 7068 & 47.78986 & -122.38863 & 40 \\
\hline$\bullet 10018$ & 391 & 47.77521 & -122.27981 & 142 \\
\hline 10019 & 7050 & 47.77621 & -122.10849 & 104 \\
\hline 10020 & 7088 & 47.80087 & -121.89000 & 354 \\
\hline 10021 & 7094 & 47.73244 & -122.25730 & 108 \\
\hline 10022 & 7096 & 47.71570 & -122.12720 & 27 \\
\hline$\bullet 10023$ & 7438 & 47.72196 & -121.89069 & 114 \\
\hline$\bullet 10024$ & 7279 & 47.65700 & -122.40850 & 93 \\
\hline 10025 & 7622 & 47.65810 & -122.27400 & 31 \\
\hline$\bullet 10026$ & 7600 & 47.64620 & -122.16626 & 149 \\
\hline$\bullet 10027$ & 192 & 47.74043 & -121.97816 & 79 \\
\hline$\bullet 10028$ & 7611 & 47.63958 & -122.00745 & 46 \\
\hline$\bullet 10029$ & 7624 & 47.63200 & -121.88080 & 53 \\
\hline 10030 & 7095 & 47.65570 & -121.79087 & 439 \\
\hline$\bullet 10031$ & 878 & 47.64414 & -121.69344 & 412 \\
\hline$\bullet 10032$ & 7294 & 47.46592 & -121.98399 & 267 \\
\hline 10033 & 7071 & 47.58260 & -122.28907 & 1 \\
\hline$\bullet 10034$ & 7297 & 47.56334 & -122.12078 & 219 \\
\hline 10035 & 7053 & 47.56550 & -121.91008 & 29 \\
\hline 10036 & 7350 & 47.54175 & -121.72909 & 315 \\
\hline 10037 & 7101 & 47.51189 & -122.38010 & 119 \\
\hline 10038 & 7108 & 47.54042 & -122.27766 & 37 \\
\hline$\bullet 10039$ & 7601 & 47.45223 & -122.28156 & 148 \\
\hline$\bullet 10040$ & 7619 & 47.47111 & -122.11353 & 114 \\
\hline 10041 & 7062 & 47.39524 & -122.19449 & 143 \\
\hline 10042 & 7113 & 47.37181 & -122.30889 & 68 \\
\hline 10043 & 7109 & 47.36834 & -122.08693 & 119 \\
\hline 10044 & 7054 & 47.40784 & -121.95686 & 213 \\
\hline 10045 & 7467 & 47.44480 & -121.72298 & 210 \\
\hline 10046 & 7076 & 47.31839 & -122.38262 & 83 \\
\hline 10047 & 7103 & 47.31361 & -122.19441 & 104 \\
\hline 10048 & 7342 & 47.31293 & -121.90073 & 262 \\
\hline 10049 & 7086 & 47.25644 & -122.08354 & 169 \\
\hline & & & & \\
\hline
\end{tabular}

\begin{tabular}{|r|r|r|r|r|}
\hline 10050 & 7346 & 47.22514 & -122.41480 & 89 \\
\hline 10051 & 7087 & 47.21838 & -122.27387 & 136 \\
\hline 10052 & 7084 & 47.19603 & -122.53663 & 67 \\
\hline$\bullet 10053$ & 384 & 47.14730 & -122.59277 & 102 \\
\hline 10054 & 7065 & 47.14832 & -122.08552 & 189 \\
\hline 10055 & 7328 & 47.10271 & -122.51340 & 88 \\
\hline 10056 & 7060 & 47.11840 & -122.25942 & 181 \\
\hline$\bullet 10057$ & 875 & 47.19489 & -121.95976 & 244 \\
\hline 10058 & 7090 & 47.11481 & -122.41840 & 107 \\
\hline$\bullet 10059$ & 553 & 47.03820 & -122.38978 & 143 \\
\hline$\bullet 10060$ & 7609 & 46.95748 & -122.22510 & 226 \\
\hline 11001 & 7337 & 48.52200 & -124.37238 & 141 \\
\hline 11002 & 6116 & 48.46436 & -124.20221 & 147 \\
\hline 11003 & 6126 & 48.43786 & -124.04447 & 212 \\
\hline 11004 & 6110 & 48.37991 & -123.82990 & 78 \\
\hline 11005 & 6119 & 48.33655 & -123.63596 & 42 \\
\hline 11006 & 6039 & 48.43170 & -123.46930 & 31 \\
\hline$\bullet 11007$ & 7301 & 48.48839 & -123.32809 & 44 \\
\hline$\bullet 1107 \mathrm{~A}$ & 7301 & 48.47805 & -123.34097 & 64 \\
\hline$\bullet 11008$ & 7287 & 48.53711 & -123.42348 & 109 \\
\hline$\bullet 11009$ & 7606 & 48.69453 & -123.44014 & 97 \\
\hline 11010 & 6113 & 48.59210 & -124.20870 & 145 \\
\hline 11011 & 6058 & 48.52766 & -123.94405 & 472 \\
\hline 11012 & 6111 & 48.44856 & -123.73988 & 140 \\
\hline 11013 & 6060 & 48.71879 & -124.13007 & 280 \\
\hline 11014 & 7344 & 48.67678 & -123.90354 & 530 \\
\hline 11015 & 6109 & 48.57412 & -123.65498 & 200 \\
\hline 11016 & 7343 & 48.67360 & -123.70840 & 284 \\
\hline$\bullet 11017$ & 7599 & 48.79884 & -123.15541 & 186 \\
\hline$\bullet 11018$ & 7280 & 48.85273 & -123.28708 & 83 \\
\hline$\bullet 11019$ & 7625 & 48.91217 & -123.41275 & 91 \\
\hline$\bullet 11020$ & 7299 & 49.00126 & -123.58513 & 40 \\
\hline$\bullet 11021$ & 7610 & 49.13327 & -123.70140 & 15 \\
\hline 11022 & 7331 & 49.18940 & -123.84224 & 66 \\
\hline 11023 & 7337 & 49.24688 & -124.13186 & 102 \\
\hline 11024 & 7456 & 49.28920 & -124.26460 & 98 \\
\hline 11025 & 6126 & 49.36021 & -124.55196 & 98 \\
\hline 11025 & 6113 & 49.36021 & -124.55196 & 98 \\
\hline 11026 & 6113 & 49.44801 & -124.71729 & 80 \\
\hline 11026 & 7337 & 49.44801 & -124.71729 & 80 \\
\hline 11027 & 6116 & 49.57209 & -124.91459 & 115 \\
\hline 11027 & 6060 & 49.57209 & -124.91459 & 115 \\
\hline 11028 & 6058 & 49.74435 & -124.96417 & 78 \\
\hline & & & & \\
\hline
\end{tabular}




\begin{tabular}{|r|r|r|r|r|}
\hline 11029 & 6060 & 49.84638 & -125.15021 & 79 \\
\hline 11029 & 6116 & 49.84638 & -125.15021 & 79 \\
\hline$\bullet 11030$ & 7277 & 48.99948 & -123.08761 & 46 \\
\hline$\bullet 11031$ & 7623 & 49.09759 & -123.16613 & 3 \\
\hline$\bullet 11032$ & 7284 & 49.20780 & -123.20110 & 5 \\
\hline$\bullet 11033$ & 7628 & 49.37259 & -123.35300 & 151 \\
\hline 11034 & 7332 & 49.51485 & -123.26071 & 75 \\
\hline 11035 & 7429 & 49.69002 & -123.14189 & 14 \\
\hline 11036 & 7351 & 49.84851 & -123.14893 & 362 \\
\hline 11037 & 7281 & 50.01199 & -123.12417 & 417 \\
\hline 11038 & 7429 & 50.13873 & -122.97090 & 639 \\
\hline 11039 & 7332 & 50.29668 & -122.81987 & 251 \\
\hline 11041 & 7281 & 50.76848 & -122.79745 & 1148 \\
\hline 11042 & 7351 & 50.91822 & -122.77316 & 852 \\
\hline 11043 & 7431 & 49.43293 & -123.62201 & 168 \\
\hline 11044 & 7445 & 49.46926 & -123.78085 & 26 \\
\hline 11045 & 7360 & 49.54428 & -123.96990 & 56 \\
\hline 11046 & 7348 & 49.64117 & -124.06438 & 32 \\
\hline 11047 & 7446 & 49.78119 & -124.18988 & 30 \\
\hline 11048 & 7430 & 49.78960 & -124.44199 & 72 \\
\hline 11049 & 7449 & 49.89324 & -124.58886 & 64 \\
\hline 11050 & 7333 & 49.99049 & -124.77668 & 32 \\
\hline 11051 & 7322 & 49.75872 & -124.61613 & 114 \\
\hline 11052 & 7433 & 49.65440 & -124.40199 & 236 \\
\hline 11053 & 7612 & 49.56184 & -124.20385 & 397 \\
\hline$\bullet$ COBS1 & & 49.02985 & -123.37678 & -256 \\
\hline$\bullet$ COBS2 & & 49.16065 & -123.34257 & -188 \\
\hline$\bullet$ COBS3 & & 49.28722 & -123.30885 & -106 \\
\hline$\bullet$ COBS4 & & 49.27663 & -123.51692 & -284 \\
\hline$\bullet$ COBS5 & & 49.26493 & -123.72753 & -423 \\
\hline$\bullet$ COBS6 & & 49.35255 & -124.03270 & -334 \\
\hline$\bullet$ UOBS1 & $\mathrm{c} 9$ & 47.88630 & -122.48005 & -200 \\
\hline$\bullet$ UOBS2 & $\mathrm{a} 3$ & 47.82007 & -122.44609 & -185 \\
\hline$\bullet$ UOBS3 & $\mathrm{a} 1$ & 47.77423 & -122.44812 & -210 \\
\hline$\bullet$ UOBS4 & $\mathrm{c} 4$ & 47.70578 & -122.44392 & -197 \\
\hline$\bullet$ UOBS5 & $\mathrm{d} 1$ & 47.64988 & -122.45830 & -220 \\
\hline$\bullet$ UOBS6 & $\mathrm{d} 4$ & 47.55924 & -122.46157 & -195 \\
\hline$\bullet$ UOBS7 & $\mathrm{a} 8$ & 47.49326 & -122.41073 & -193 \\
\hline$\bullet$ UOBS8 & $\mathrm{c} 1$ & 47.43661 & -122.38993 & -225 \\
\hline$\bullet U O B S 9$ & $\mathrm{a} 4$ & 47.35736 & -122.35752 & -171 \\
\hline$\bullet$ ALD & DR200 & 47.57492 & -122.41781 & 3 \\
\hline RHR & DR200 & 47.57089 & -122.38875 & 114 \\
\hline
\end{tabular}

\begin{tabular}{|r|r|r|r|r|}
\hline$\bullet$ CLL & DR200 & 47.58325 & -122.38854 & 96 \\
\hline$\bullet$ DAK & DR200 & 47.56728 & -122.38889 & 114 \\
\hline$\bullet$ EAK & K2 & 47.57375 & -122.38202 & 120 \\
\hline$\bullet$ HAN & K2 & 47.57442 & -122.38872 & 107 \\
\hline$\bullet$ HOL & DR200 & 47.58691 & -122.38834 & 90 \\
\hline$\bullet$ KD1 & Reftek & 47.59521 & -122.33337 & 4 \\
\hline$\bullet$ LAN & DR200 & 47.57889 & -122.38865 & 104 \\
\hline$\bullet$ SQ1 & Reftek & 47.54968 & -122.25038 & 10 \\
\hline$\bullet$ WEK & K2 & 47.57453 & -122.38403 & 119 \\
\hline$\bullet$ WIN & K2 & 47.57475 & -122.38200 & 119 \\
\hline
\end{tabular}

- 3-component site

$\Delta$ Location from topographic map 
Appendix 3. List of timing used for Reftek stations (Times in UTC)

\begin{tabular}{|c|c|c|}
\hline $\begin{array}{c}\text { Station } \\
\text { Name }\end{array}$ & \begin{tabular}{c|} 
DAS \\
No.
\end{tabular} & Timing used in segygather.csh \\
\hline 1001 & 642 & No timing and no data, and no logfile! \\
\hline 1001 & 7347 & No timing and no data, and no logfile! \\
\hline 1002 & 6095 & $\begin{array}{l}\text { GPS and Pulsed (Manual refrate), GPS never locked, no GPS locks or pulses after JD } \\
\text { 076:0031 }\end{array}$ \\
\hline 1003 & 6041 & GPS (okay), 13 msec sawteeth, fix12secbug, ran scripts \\
\hline 1004 & 7278 & GPS (excellent) $<1 \mathrm{msec}$ errors \\
\hline 1005 & 7447 & GPS (okay), $<5$ msec errors, two 7 msec spikes \\
\hline 1006 & 6035 & GPS (excellent) $<1 \mathrm{msec}$ errors, fix 12secbug, no problem \\
\hline 1007 & 7111 & Pulsed (Auto refrate) \\
\hline 1007 & 6097 & Pulsed (Manual refrate) - timing only from JD 073 to JD 075 \\
\hline 1008 & 550 & GPS (okay), with 14 msec sawteeth, last GPS lock JD 083:2056 \\
\hline 1009 & 7097 & Pulsed (Manual refrate) - Only one pulse, no GPS!! \\
\hline 1009 & 6062 & GPS (excellent), $<1 \mathrm{msec}$ errors, edit logfile only on first pass \\
\hline 1010 & 7059 & Pulsed (Auto refrate), data from JD 069 to JD 078 only, 1st pulse JD 068:1947 \\
\hline 1011 & 7602 & GPS (excellent), $<1 \mathrm{msec}$ errors \\
\hline 1012 & 6056 & Pulsed (Auto refrate), deleted out peaks and duplicate times, 1st pulse JD 068:2032 \\
\hline 1013 & 6121 & Pulsed (Auto refrate), deleted out peaks and duplicate times \\
\hline 1014 & 7298 & GPS (Manual refrate), 2 1-2 hour spikes in GPS time \\
\hline 1015 & 6086 & Pulsed (Auto refrate), 1st pulse JD 068:2312 \\
\hline 1016 & 7069 & Pulsed (Auto refrate) \\
\hline 1017 & 7285 & GPS (excellent), $<2 \mathrm{msec}$ errors \\
\hline 1018 & 7083 & Pulsed (Auto refrate) \\
\hline 1019 & 7289 & GPS (excellent), $<1 \mathrm{msec}$ errors, lost header values \\
\hline 1020 & 7286 & GPS (excellent), $<1 \mathrm{msec}$ errors \\
\hline 1021 & 7357 & GPS (excellent), $<1 \mathrm{msec}$ errors \\
\hline 1022 & 7345 & GPS (excellent), $<2 \mathrm{msec}$ errors \\
\hline 2001 & 153 & GPS (excellent), $<1 \mathrm{msec}$ errors \\
\hline 2002 & 6032 & $\begin{array}{l}\text { Pulsed (Auto refrate), 2nd pass edited pcf to change } 1988 \text { to 1998, segymod year, } \\
\text { event file names changed also }\end{array}$ \\
\hline 2003 & 6021 & $\begin{array}{l}\text { Pulsed (Auto refrate), 2nd pass edited to remove 1988, segymod year, event file names } \\
\text { changed also }\end{array}$ \\
\hline 2004 & 7593 & GPS (okay), 12-13 msec sawteeth \\
\hline 2004 & 6091 & GPS (Manual refrate), 3 pulses, all JD 075:2232, recorded only 4 hrs of line 5 \\
\hline 2004 & 6088 & Pulsed (Auto refrate), recorded lines 8-11 \\
\hline 2005 & 6047 & $\begin{array}{l}\text { Pulsed and GPS (Auto refrate), 2nd pass edited to remove 1988, segymod year, event } \\
\text { file names changed also }\end{array}$ \\
\hline 2006 & 7300 & GPS (very good) \\
\hline 2007 & 6122 & $\begin{array}{l}\text { Pulsed (Auto refrate), 2nd pass edited to remove 1988, segymod year, event file names } \\
\text { changed also }\end{array}$ \\
\hline
\end{tabular}




\begin{tabular}{|c|c|c|}
\hline 2008 & 6093 & $\begin{array}{l}\text { Pulsed (Auto refrate), 2nd pass edited to remove 1988, segymod year, event file names } \\
\text { changed also, last pulse 083:2010 }\end{array}$ \\
\hline 2009 & 6031 & Pulsed and GPS (Manual refrate), 1st pulse JD 068:2006, last pulse JD 083:1756 \\
\hline 2010 & 6087 & $\begin{array}{l}\text { Pulsed and GPS (Manual refrate), 2nd pass edited to remove 1988, segymod year, event } \\
\text { file names changed also, fix12secbug, no problem, 1st pulse 068:1807, last pulse } \\
\text { 083:1656 }\end{array}$ \\
\hline 2011 & 359 & GPS (very good) \\
\hline 2012 & 149 & GPS (very good) \\
\hline 2012 & 6064 & GPS (excellent), 14 GPS locks in 4 hours \\
\hline 2013 & 340 & GPS (excellent) \\
\hline 2014 & 6071 & $\begin{array}{l}\text { Pulsed (Manual refrate), not edited, ran fix12secbug, no problem; 1st pulse JD } \\
\text { 068:2117, last pulse JD 083:1722 }\end{array}$ \\
\hline 3001 & 6057 & $\begin{array}{l}\text { GPS (Manual refrate), pulsed JD 068:0144; ran fix12secbug, ran script, refrate with } \\
\text { corrected log files }\end{array}$ \\
\hline 3002 & 529 & GPS (okay), duplicate entries, not edited \\
\hline 3003 & 6081 & GPS (Manual refrate), a few short spikes were not edited, 1st pulse JD 068:0020 \\
\hline 3004 & 6125 & GPS (Manual refrate), no GPS locks before JD 070, 1st pulse JD 067:2327 \\
\hline 3005 & 7044 & Pulsed (Auto refrate) \\
\hline 3006 & 880 & GPS (Manual refrate), numerous short spikes \\
\hline 3007 & 7064 & Pulsed (Auto refrate), deleted first line \\
\hline 3008 & 7058 & Pulsed (Auto refrate), deleted first line \\
\hline 3009 & 348 & GPS (excellent), $<1 \mathrm{msec}$ errors \\
\hline 3010 & 7081 & Pulsed (Auto refrate), duplicate entries in .pcf deleted on 2nd pass \\
\hline 3011 & 6045 & GPS (excellent), $<2$ msec errors \\
\hline 3012 & 7283 & GPS (okay), 13 msec sawteeth errors \\
\hline 3013 & 7362 & GPS (okay), $<8$ msec errors \\
\hline 3014 & 7597 & GPS (excellent) \\
\hline 4001 & 898 & GPS (Manual refrate), last pulse JD 084:0051 \\
\hline 4002 & 7066 & Pulsed (Manual refrate), 1st pulse JD 071:1651 \\
\hline 4003 & 7288 & GPS (okay), 11 msec sawteeth \\
\hline 4004 & 7078 & Pulsed (Auto refrate), deleted 1st 2 lines in .pcf file \\
\hline 4004 & 6066 & Pulsed (Auto refrate) 1st pulse JD 075:1843 at start of data acquisition \\
\hline 4005 & 7100 & GPS and pulsed (Manual refrate), 1st pulse JD 067:2315, last pulse JD 083:1810 \\
\hline 4006 & 7112 & Pulsed (Auto refrate), not timed on start day \\
\hline 4006 & 6120 & $\begin{array}{l}\text { Pulsed (Manual refrate), lines 7-11, deleted 1st } 2 \text { lines in .pcf file, 1st pulse JD } \\
\text { 079:2242 at start of acquisition }\end{array}$ \\
\hline 4007 & 7282 & GPS (good to excellent), generally $<2 \mathrm{msec}$ errors, $8 \mathrm{msec}$ sawtooth near end \\
\hline 4008 & 7063 & GPS and pulsed (Manual refrate), 1st pulse JD 068:2208 \\
\hline 4009 & 7110 & GPS and pulsed (Manual refrate), 1st pulse JD 067:1857 \\
\hline 4010 & 6020 & GPS and pulsed (Manual refrate), 1st pulse JD 067:2218 \\
\hline 4011 & 6108 & GPS (Manual refrate), no GPS lock on last day, last pulse JD 083:2350 \\
\hline 4012 & 6037 & Pulsed (Manual refrate), 2nd pass ran fix12secbug, script, last pulse JD 083:2248 \\
\hline 4013 & 6085 & Pulsed (Manual refrate), 2nd pass deleted duplicates in .pcf file, last pulse JD 081:1926 \\
\hline 5001 & 7107 & Pulsed (Auto refrate) \\
\hline
\end{tabular}




\begin{tabular}{|c|c|c|}
\hline 5002 & 895 & GPS (Manual refrate), no GPS in middle of recording window \\
\hline 5003 & 395 & GPS (good) \\
\hline 5004 & 6025 & GPS (very good), 2nd pass ran fix 12 secbug, script \\
\hline 5005 & 7077 & Pulsed (Auto refrate) \\
\hline 5006 & 7039 & Pulsed (Auto refrate), deleted 1st 2 lines \\
\hline 5007 & 877 & GPS (no data lines 4-11) \\
\hline 5008 & 369 & GPS (excellent) \\
\hline 5009 & 656 & GPS (very good), 2nd pass ran fix12secbug, script \\
\hline 6001 & 7291 & GPS (very good) \\
\hline 6002 & 6084 & Pulsed (Auto refrate), deleted 1st 3 lines \\
\hline 6003 & 6080 & GPS (excellent) \\
\hline 6004 & 7595 & GPS (good) \\
\hline 6005 & 6051 & Pulsed (Auto refrate) \\
\hline 6006 & 6098 & Pulsed (Auto refrate), deleted entries for 1998:001 \\
\hline 6007 & 7448 & GPS (good) \\
\hline 6008 & 7444 & GPS (excellent) \\
\hline 6009 & 7605 & GPS (okay), 10 msec sawtooth pattern \\
\hline 6010 & 6114 & GPS (excellent), no data before first lock JD 072:0115 (after lines 1-2) \\
\hline 6010 & 6003 & No data! Not processed! \\
\hline 6011 & 7615 & GPS (okay), $<10 \mathrm{msec}$ errors \\
\hline 6012 & 7594 & GPS (excellent) $<1 \mathrm{msec}$ errors \\
\hline 6013 & 6019 & Pulsed (Auto refrate) \\
\hline 6014 & 6067 & Pulsed (Auto refrate) \\
\hline 7001 & 7056 & GPS (Manual refrate), $100 \mathrm{msec}$ sawteeth of GPS clock, 1st lock JD 070:0700 \\
\hline 7002 & 7604 & GPS (excellent) \\
\hline 7003 & 7052 & GPS (okay), $10 \mathrm{msec}$ sawteeth, $40 \mathrm{msec}$ peak at JD 083 ignored \\
\hline 7004 & 7306 & GPS (excellent) $<1 \mathrm{msec}$ error \\
\hline 7005 & 6090 & GPS (excellent) $<2$ to $3 \mathrm{msec}$ errors \\
\hline 7006 & 7070 & GPS failed (Manual refrate), partial line 2 only, no timing (GPS or pulse) for line 2 \\
\hline 7006 & 6102 & GPS (good, 1 drift of $\sim 5 \mathrm{msec}$ ) \\
\hline 7007 & 6042 & GPS (excellent), fix 12secbug was run, no problems, NO LINE 1 \\
\hline 7008 & 7292 & GPS (excellent) \\
\hline 7009 & 381 & $\begin{array}{l}\text { GPS (Manual refrate), JD 069-075 no GPS locks (but low drift rate } \sim 50 \mathrm{msec} \text { ), } \\
\text { fix12secbug, script, refrate with segyshift }\end{array}$ \\
\hline 7010 & 7316 & GPS (excellent) $<1 \mathrm{msec}$ errors \\
\hline 7011 & 7085 & GPS (excellent) $<3 \mathrm{msec}$ errors \\
\hline 7012 & 7592 & No data \\
\hline 7012 & 6107 & $\begin{array}{l}\text { GPS (manual refrate), 1st lock JD 076:0020 at start of acquisition, JD 078:1100-1500 } \\
250 \text { msec peak with no locks, last lock JD 080:2000 at end of acquisition }\end{array}$ \\
\hline 8001 & 6092 & GPS (excellent) $<1 \mathrm{msec}$ errors \\
\hline 8002 & 6040 & GPS (okay), 10 msec sawteeth \\
\hline 8003 & 7614 & GPS (generally <2 msec errors, one $10 \mathrm{msec}$ peak) \\
\hline 8004 & 6101 & GPS (excellent) < $1 \mathrm{msec}$ errors, ran fix 12secbug no problems, last lock JD 084:0000 \\
\hline 8005 & 6118 & GPS (okay), $<6$ msec errors, ran fix12secbug no problems, last lock JD 084:0000 \\
\hline
\end{tabular}




\begin{tabular}{|c|c|c|}
\hline 8006 & 7303 & GPS (good), out of sequence event at battery swap no problem \\
\hline 8007 & 6065 & GPS (okay), 12 msec sawteeth, fix12secbug, ran script, no refrate \\
\hline 8008 & 7330 & GPS (excellent), $<1 \mathrm{msec}$ errors \\
\hline 8009 & 7630 & GPS (good), $<5 \mathrm{msec}$ errors \\
\hline 8010 & 7320 & GPS (excellent), $<1 \mathrm{msec}$ errors \\
\hline 8011 & 7460 & GPS (excellent), $<3 \mathrm{msec}$ errors \\
\hline 8012 & 7295 & GPS (excellent), $<1 \mathrm{msec}$ errors \\
\hline 8013 & 7462 & GPS (good), $<7$ msec errors \\
\hline 8014 & 7440 & GPS (good), ignored a couple of time jerks \\
\hline 9001 & 7104 & GPS (good) \\
\hline 9002 & 7046 & GPS (good) \\
\hline 9003 & 6028 & Pulsed (Auto refrate), edited to remove duplicate \\
\hline 9004 & 7099 & Pulsed (Auto refrate), no data lines 6-11 (after JD 077) \\
\hline 9004 & 6018 & Pulsed (Auto refrate), duplicate logs warning, not found in .pcf file \\
\hline 9005 & 6046 & Pulsed (Auto refrate), deleted 1st line \\
\hline 9006 & 7598 & GPS (good) \\
\hline 9007 & 7092 & GPS (okay), 5 msec half-step in middle \\
\hline 9008 & 7072 & GPS (okay), $10 \mathrm{msec}$ sawteeth, ran fix 12 secbug, ran script \\
\hline 9009 & 7116 & GPS (Manual refrate), edited pcf file \\
\hline 9010 & 7038 & GPS (okay), $<10$ msec errors \\
\hline 9011 & 7428 & GPS (Auto refrate), not edited to remove $26 \mathrm{msec}$ pulses \\
\hline 9012 & 227 & GPS (excellent), $<3 \mathrm{msec}$ errors \\
\hline 9012 & 6030 & GPS (very good) \\
\hline 9012 & 6069 & GPS (Manual refrate), bad GPS clock!! \\
\hline 9012 & 7466 & GPS (Manual? refrate) \\
\hline 9013 & 7324 & GPS (good) \\
\hline 9014 & 7296 & GPS (excellent), $<1 \mathrm{msec}$ errors \\
\hline 9015 & 7098 & GPS (looks good) \\
\hline 9016 & 7061 & GPS (okay), 12 msec sawteeth (4 day cycle) \\
\hline 9017 & 7452 & GPS (Manual refrate), $15 \mathrm{msec}$ offsets \\
\hline 9018 & 7302 & GPS (good!) \\
\hline 9019 & 7454 & GPS (good) \\
\hline 9021 & 7352 & GPS (excellent) \\
\hline 9022 & 7435 & GPS (Manual refrate) \\
\hline 9023 & 338 & GPS (good), ran fix12secbug, no problem \\
\hline 9024 & 7317 & GPS (okay), 10 msec sawteeth \\
\hline 9025 & 7089 & GPS (excellent) \\
\hline 9026 & 7466 & GPS (Manual? Refrate) \\
\hline 9027 & 7339 & GPS (okay), 6 msec sawteeth \\
\hline 9028 & 7073 & GPS (Manual refrate), $32 \mathrm{msec}$ spikes \\
\hline 9029 & 771 & $\begin{array}{l}\text { GPS (Manual refrate), } 400 \text { msec errors, GPS has large driftrate and offsets, 1st lock JD } \\
\text { 066:2338, last lock JD 083:1700 }\end{array}$ \\
\hline 9030 & 7075 & GPS (okay) \\
\hline 9030 & 6029 & Pulsed (Auto refrate) \\
\hline
\end{tabular}




\begin{tabular}{|c|c|c|}
\hline 9031 & 6026 & Pulsed (Auto refrate) \\
\hline 10001 & 7041 & GPS (okay), $11 \mathrm{msec}$ sawteeth \\
\hline 10002 & 7114 & GPS, no data JD 075 to JD 077 \\
\hline 10003 & 7334 & GPS (Manual? refrate) \\
\hline 10004 & 7627 & $\begin{array}{l}\text { GPS (Manual refrate), pulsed at end of acquisition, deleted one out of sequence event } \\
\text { from .pcf file }\end{array}$ \\
\hline 10005 & 7074 & GPS (excellent), $<1 \mathrm{msec}$ errors \\
\hline 10006 & 556 & GPS, no data, GPS locks only on JD 075 and 076 \\
\hline 10007 & 7364 & GPS (okay), up to $18 \mathrm{msec}$ sawteeth \\
\hline 10008 & 7047 & GPS (excellent), $<1 \mathrm{msec}$ errors \\
\hline 10009 & 7040 & GPS (excellent), $<1 \mathrm{msec}$ errors \\
\hline 10010 & 7629 & GPS (excellent), generally $<2 \mathrm{msec}$ errors, deleted one out of sequence data event \\
\hline 10011 & 7043 & GPS (okay), 11 msec sawteeth \\
\hline 10012 & 7591 & GPS (excellent), $<1 \mathrm{msec}$ errors, ignored one short spike \\
\hline 10013 & 7082 & GPS (excellent), $<1 \mathrm{msec}$ errors \\
\hline 10014 & 7341 & GPS (good), $<5$ msec errors \\
\hline 10015 & 7091 & GPS (okay), $<10 \mathrm{msec}$ errors \\
\hline 10016 & 7093 & GPS (good), $<5$ msec errors \\
\hline 10017 & 7068 & GPS, generally $<10 \mathrm{msec}$ errors, up to $30 \mathrm{msec}$ spikes \\
\hline 10018 & 391 & GPS (okay) $<10 \mathrm{msec}$ errors, several short $18 \mathrm{msec}$ errors during JD 069-070 ignored \\
\hline 10019 & 7050 & GPS (okay), generally $<5 \mathrm{msec}$ errors with $13 \mathrm{msec}$ sawteeth \\
\hline 10020 & 7088 & GPS (excellent), $<1 \mathrm{msec}$ errors \\
\hline 10021 & 7094 & GPS (okay), 13 msec sawteeth \\
\hline 10022 & 7096 & Pulsed (Auto refrate), 1st pulse JD 069:1927 \\
\hline 10023 & 7438 & GPS (excellent), <2 msec errors, no data before JD 076:1950 (no lines 1-4) \\
\hline 10024 & 7279 & Pulsed (Auto refrate), not pulsed on start day, 1st pulse JD 068 \\
\hline 10025 & 7609 & GPS (good), generally $<2 \mathrm{msec}$ errors, $423 \mathrm{msec}$ spike on JD 068 \\
\hline 10025 & 7622 & Pulsed (Auto refrate), lst pulse 069:1927 \\
\hline 10026 & 7600 & GPS (excellent), $<3 \mathrm{msec}$ errors \\
\hline 10027 & 192 & GPS (good), $<5$ msec errors \\
\hline 10028 & 7611 & GPS (excellent) $<1 \mathrm{msec}$ error for 069:1542 to 083:2246 \\
\hline 10029 & 7624 & Recorded only 4 events, $075: 1630$ to $075: 1830$, no locks or pulses \\
\hline 10030 & 7095 & GPS (good) $<7$ msec errors \\
\hline 10031 & 878 & GPS (excellent), $<1 \mathrm{msec}$ error \\
\hline 10032 & 7294 & GPS (excellent), $<1 \mathrm{msec}$ error \\
\hline 10033 & 7071 & GPS (excellent), $<5 \mathrm{msec}$ error \\
\hline 10034 & 7297 & GPS (good), ignored one time jerk \\
\hline 10035 & 7053 & $\begin{array}{l}\text { GPS (Manual refrate), fix 12secbug, then script, no duplicates found, last lock JD } \\
\text { 083:2000 }\end{array}$ \\
\hline 10036 & 7350 & GPS (excellent), $<1 \mathrm{msec}$ error, last lock JD 083:1300 \\
\hline 10037 & 7101 & GPS (good) $<10$ msec error \\
\hline 10038 & 7108 & GPS (excellent), $<2 \mathrm{msec}$ error \\
\hline 10039 & 7601 & GPS (excellent), $<3 \mathrm{msec}$ errors \\
\hline 10040 & 7619 & GPS (ignored a $24 \mathrm{hr} 46 \mathrm{msec}$ peak on JD 070) \\
\hline
\end{tabular}




\begin{tabular}{|c|c|c|}
\hline 10041 & 7062 & No data \\
\hline 10042 & 7113 & GPS (excellent), one $10 \mathrm{msec}$ spike, ran fix12secbug, ran script \\
\hline 10043 & 7109 & GPS (excellent), $<1 \mathrm{msec}$ error, ran fix 12 secbug, ran script \\
\hline 10044 & 7054 & GPS (excellent), $<4$ msec errors, ran fix12secbug, no problem \\
\hline 10045 & 7467 & GPS (excellent), $<1 \mathrm{msec}$ error \\
\hline 10046 & 7076 & $\begin{array}{l}\text { GPS (Manual refrate), no GPS between 072:2000 and 083, deleted } 4 \text { lines at end of pcf } \\
\text { file, ran fix12secbug, no problem }\end{array}$ \\
\hline 10047 & 7103 & GPS (excellent), $<2$ msec error - forgot to run fix12secbug, has 2 events \\
\hline 10048 & 7342 & GPS (excellent), $<2 \mathrm{msec}$ error, ignore 3 daily peaks up to $26 \mathrm{msec}$ JD $081-083$ \\
\hline 10049 & 7086 & GPS (excellent), $<2 \mathrm{msec}$ error, ran fix 12secbug, ran script \\
\hline 10050 & 7346 & GPS (excellent), $<1 \mathrm{msec}$ error \\
\hline 10051 & 7087 & GPS (excellent), $<1 \mathrm{msec}$ error, ran fix 12secbug, ran script \\
\hline 10052 & 7084 & GPS (good), ran fix12secbug, no problem \\
\hline 10053 & 384 & GPS (excellent), $<1 \mathrm{msec}$ error \\
\hline 10054 & 7065 & GPS (excellent), $<1 \mathrm{msec}$ error, ran fix 12 secbug, no problem \\
\hline 10055 & 7328 & GPS (okay), 10 msec sawteeth \\
\hline 10056 & 7060 & GPS (excellent), $<1 \mathrm{msec}$ error, ran fix 12 secbug, ran script \\
\hline 10057 & 875 & GPS (excellent), $<3 \mathrm{msec}$ errors \\
\hline 10058 & 7090 & GPS (excellent), <1 msec error \\
\hline 10059 & 553 & GPS (Manual refrate), up to $50 \mathrm{msec}$ sawteeth \\
\hline 10060 & 7609 & GPS (excellent), $<1 \mathrm{msec}$ error \\
\hline 11001 & 7337 & GPS, removed JD 013 entry from near JD 073:0200 in logfile \\
\hline 11002 & 6116 & GPS, only 2 GPS locks (46 msec drift) \\
\hline 11003 & 6126 & GPS (Manual refrate), Poor timing because there are only 17 GPS locks \\
\hline 11004 & 6110 & GPS (good), $<10$ msec errors \\
\hline 11005 & 6119 & GPS (okay), 17-25 msec sawteeth ignored \\
\hline 11006 & 6039 & Pulsed (Auto refrate) deleted 1st 2 lines in .pcf file \\
\hline 11007 & 7301 & GPS (excellent) <1 msec error, 1st lock JD 070:0000 \\
\hline $1107 \mathrm{~A}$ & 7301 & GPS (excellent) $<1 \mathrm{msec}$ error, 1st lock JD 070:0000 \\
\hline 11008 & 7287 & GPS (Manual refrate), $62 \mathrm{msec}$ sawtooth peaks \\
\hline 11009 & 7606 & GPS (good), $<2.5 \mathrm{msec}$ errors \\
\hline 11010 & 6113 & GPS (Manual refrate), JD 069-074 few GPS locks, $100 \mathrm{msec}$ sawteeth \\
\hline 11011 & 6058 & GPS (excellent), generally $<1 \mathrm{msec}$ error \\
\hline 11012 & 6111 & GPS (Manual refrate), no GPS locks JD 070 to JD 074 and from JD 079 to JD 084 \\
\hline 11013 & 6060 & GPS (excellent), $<1 \mathrm{msec}$ error \\
\hline 11014 & 7344 & GPS (Manual refrate), GPS missing JD 070:2358 to JD 079:0225 \\
\hline 11015 & 6109 & Pulsed (Auto refrate), deleted before JD 069:2300 in .pcf file \\
\hline 11016 & 7343 & GPS (okay), 10 msec sawtooth pattern \\
\hline 11017 & 7599 & GPS and pulsed (Manual refrate), last lock JD 080:1200, last pulse JD 085:1752 \\
\hline 11018 & 7280 & GPS (good) \\
\hline 11019 & 7625 & GPS (excellent), $<1 \mathrm{msec}$ errors \\
\hline 11020 & 7299 & GPS (excellent), $<1 \mathrm{msec}$ errors \\
\hline 11021 & 7610 & GPS (okay), up to $8 \mathrm{msec}$ errors \\
\hline 11022 & 7331 & GPS (excellent), $<1 \mathrm{msec}$ error, last lock JD 083:2348 \\
\hline
\end{tabular}




\begin{tabular}{|c|c|c|}
\hline 11023 & 7337 & GPS, edited logfile to remove JD 013 event from near JD 073:0200 in logfile \\
\hline 11024 & 7456 & Pulsed (Auto refrate), infrequently pulsed, deleted out of sequence events \\
\hline 11025 & 6113 & GPS (Manual refrate), few GPS locks from JD 069 to JD 074, $100 \mathrm{msec}$ sawteeth \\
\hline 11025 & 6126 & GPS (Manual refrate), Poor timing because there are only 17 GPS locks \\
\hline 11026 & 6113 & GPS (Manual refrate), few GPS locks from JD 069 to JD 074, $100 \mathrm{msec}$ sawteeth \\
\hline 11026 & 7337 & GPS, edited logfile to remove JD 013 event from near JD 073:0200 in logfile \\
\hline 11027 & 6060 & GPS (excellent), $<1 \mathrm{msec}$ error \\
\hline 11027 & 6116 & GPS (excellent) \\
\hline 11028 & 6058 & GPS (excellent), generally $<1 \mathrm{msec}$ error \\
\hline 11029 & 6060 & GPS (excellent), $<1 \mathrm{msec}$ error \\
\hline 11029 & 6116 & GPS (excellent) \\
\hline 11030 & 7277 & GPS (excellent),$<1 \mathrm{msec}$ error \\
\hline 11031 & 7623 & GPS (excellent), $<3 \mathrm{msec}$ error \\
\hline 11032 & 7284 & GPS (excellent), $<1 \mathrm{msec}$ error \\
\hline 11033 & 7628 & GPS (excellent), $<1 \mathrm{msec}$ error \\
\hline 11034 & 7332 & GPS (excellent) \\
\hline 11035 & 7429 & GPS (excellent) \\
\hline 11036 & 7351 & $\begin{array}{l}\text { GPS (excellent), <3 msec errors, edited to remove 1988, segymod year, event file } \\
\text { names changed also }\end{array}$ \\
\hline 11037 & 7281 & GPS (good) \\
\hline 11038 & 7429 & GPS (excellent) \\
\hline 11039 & 7332 & GPS (excellent) \\
\hline 11041 & 7281 & GPS (good) \\
\hline 11042 & 7351 & GPS (excellent), $<3 \mathrm{msec}$ errors \\
\hline 11043 & 7431 & $\begin{array}{l}\text { GPS and pulsed (Manual refrate), no GPS locks after >JD 073:0000, high GPS } \\
\text { driftrates, no locks JD 072-082, pulsed JD 082:0055 and JD 083:1634 }\end{array}$ \\
\hline 11044 & 7445 & GPS (good) \\
\hline 11045 & 7360 & GPS (generally good), one $40 \mathrm{msec}$ spike at JD 070:0000 was ignored \\
\hline 11046 & 7348 & GPS (Manual refrate), $100 \mathrm{msec}$ errors \\
\hline 11047 & 7446 & GPS (good), 29 msec spike late JD 069, ignored), lst lock JD 069:2142, 2 locks prior \\
\hline 11048 & 7430 & GPS (good) \\
\hline 11049 & 7449 & GPS (Manual refrate), $70 \mathrm{msec}$ error on JD 073), 1st lock before JD 068 \\
\hline 11050 & 7333 & GPS (Manual refrate), JD 080 large errors \\
\hline 11051 & 7322 & GPS (good) \\
\hline 11052 & 7433 & GPS (okay), $<10 \mathrm{msec}$ errors \\
\hline 11053 & 7612 & GPS (excellent), JD 070 to JD 084 \\
\hline Tully & 7356 & GPS (okay), 6 msec sawteeth \\
\hline
\end{tabular}


Appendix 4. List of stations having problems with spurious 12-second shifts

\begin{tabular}{|c|c|c|}
\hline $\begin{array}{c}\text { Station } \\
\text { Name }\end{array}$ & $\begin{array}{c}\text { DAS } \\
\text { No. }\end{array}$ & Effected Lines, JD:UTC (HrMn), and No. of 30-min-long Events \\
\hline 1003 & 6041 & Lines 4 and 9, 074:0045, 081:0104-0334, 6 events \\
\hline 3001 & 6057 & Lines 4 and 9, 074:0013, 081:0030-0130, 3 events total \\
\hline 3002 & 529 & Line 4, Ch. 4-6, 074:0014, 1 event \\
\hline 4005 & 7100 & Line 9, 081:0043-0143, 3 events \\
\hline 4011 & 6108 & Line 4, 074:0017, 1 event \\
\hline 4012 & 6037 & Line 9, 081:0112-0142, 2 events \\
\hline 5004 & 6025 & Line 9, 081:0023-0323, 6 events \\
\hline 5009 & 656 & Line 9, Ch. 4-6, 081:0012, 1 event \\
\hline 6003 & 6080 & Before shooting started, JD 067:2225, 1 spike, removed \\
\hline 7009 & 381 & Line 9, 081:0053-0423, 8 events \\
\hline 8007 & 6065 & Line 9, 081:0043-0313, 6 events \\
\hline 9001 & 7104 & Lines 4 and 9, 074:0015-0045, 081:0052-0322, 7 events \\
\hline 9008 & 7072 & Lines 4 and 9, 074:0101, 081:0039-0339, 12 events \\
\hline 9009 & 7116 & Line 9, 081:0027-0427, 8 events \\
\hline 9012 & 6030 & Line 9, 081:0022-0222, 4 events \\
\hline 9015 & 7098 & Line 9, 081:0016-0316, 6 events \\
\hline 10008 & 7047 & Line 4, 074:0016, 1 event \\
\hline 10009 & 7040 & Lines 4 and 9, 074:0047-0117, 081:0037-0337, 9 events \\
\hline 10011 & 7043 & Line 9, 081:0041-0341, 6 events \\
\hline 10013 & 7082 & Lines 4 and 9, 081:0103-0233, 4 events \\
\hline 10016 & 7093 & Line 4, 074:0022, 1 event \\
\hline 10020 & 7088 & Line 9, 081:0028-0328, 6 events \\
\hline 10035 & 7053 & Line 9, 081:0109-0839, 16 events \\
\hline 10037 & 7101 & Line 9, 081:0043, 1 event \\
\hline 10042 & 7113 & Line 9, 081:0104-0134, 2 events \\
\hline 10043 & 7109 & Line 4, 074:0043, 2 events \\
\hline 10047 & 7103 & Lines 4 and 9, 074:0043, 081:0043, 2 events total \\
\hline 10049 & 7086 & Line 9, 081:0048-0318, 6 events \\
\hline 10051 & 7087 & Line 4, 074:0052-0122, 2 events \\
\hline 10056 & 7060 & Line 9, 081:0104-0134, 2 events \\
\hline
\end{tabular}


Appendix 5. List of location of Reftek station data on archival tapes

\begin{tabular}{|c|c|c|c|c|c|c|c|c|c|c|}
\hline $\begin{array}{c}\text { Sta- } \\
\text { tion } \\
\text { Name }\end{array}$ & $\begin{array}{c}\text { DA } \\
\text { S } \\
\text { No. }\end{array}$ & Tape Name & File No. & Comments & Tape Name & File No. & Comments & Tape Name & $\begin{array}{l}\text { File } \\
\text { No. }\end{array}$ & Comments \\
\hline 1002 & 6095 & USGS DLT1A & $1-11$ & Ch. 1 & USGS DLT1B & $1-11$ & Ch. 1 & USGS DAT1 & $1-11$ & Ch. 1 \\
\hline 1004 & 7278 & copy of & $12-22$ & All zero files & & $12-22$ & All zero files & & $12-22$ & All zero files \\
\hline 1004 & 7278 & USGS DLT1B & 23-33 & Ch. 3 & & $23-33$ & Ch. 3 & & $23-33$ & Ch. 3 \\
\hline 1005 & 7447 & & $34-44$ & Ch. 1 & & $34-44$ & Ch. 1 & USGS DAT2 & $1-11$ & Ch. 1 \\
\hline 1006 & 6035 & & $45-55$ & Ch. 1 & & $45-55$ & Ch. 1 & & $12-22$ & Ch. 1 \\
\hline 1007 & 7111 & & $56-66$ & Ch. 1 & & $56-66$ & $\begin{array}{l}\text { zerofiles } 60-66 \text {, no lines } \\
5-11\end{array}$ & & $23-33$ & $\begin{array}{l}\text { zerofiles } 26-33 \text {, no lines 5- } \\
11\end{array}$ \\
\hline 1007 & 6097 & & $67-77$ & Ch. 1 & & $67-77$ & All zero files & & $34-44$ & All zero files \\
\hline 1008 & 550 & & $78-88$ & All zero files & & $78-88$ & All zero files & USGS DAT3 & $1-11$ & All zero files \\
\hline 1008 & 550 & & $89-99$ & All zero files & & $89-99$ & All zero files & & $12-22$ & All zero files \\
\hline 1008 & 550 & & $100-110$ & All zero files & & $100-110$ & All zero files & & $23-33$ & All zero files \\
\hline 1008 & 550 & & 111-121 & All zero files & & 111-121 & All zero files & & $34-44$ & All zero files \\
\hline 1008 & 550 & & $122-132$ & All zero files & & $122-132$ & All zero files & & $45-55$ & All zero files \\
\hline 1009 & 6062 & & $133-143$ & All zero files & & 133-143 & All zero files & USGS DAT4 & $1-11$ & All zero files \\
\hline 1010 & 7059 & & $144-154$ & Ch. 1 & & $144-154$ & $\begin{array}{l}\text { zerofiles 149-154, no } \\
\text { lines 6-11 }\end{array}$ & & $11-22$ & $\begin{array}{l}\text { zerofiles } 17-22 \text { no lines 6- } \\
11\end{array}$ \\
\hline 1012 & 6056 & & $155-165$ & Ch. 1 & & $155-165$ & $\begin{array}{l}\text { zerofiles 155-158, no } \\
\text { lines 1-4 }\end{array}$ & & $23-33$ & $\begin{array}{l}\text { zerofiles 23-26 no lines 1- } \\
4\end{array}$ \\
\hline 1013 & 6121 & & $166-176$ & Ch. 1 & & $166-176$ & $\begin{array}{l}\text { zerofiles } 166-169, \text { no } \\
\text { lines 1-4 }\end{array}$ & & $34-44$ & $\begin{array}{l}\text { zerofiles } 34-37 \text { no lines } 1- \\
4\end{array}$ \\
\hline 1014 & 7298 & & $177-187$ & Ch. 3 & & $177-187$ & Ch. 3 & USGS DAT5 & $1-11$ & Ch. 3 \\
\hline 1015 & 6086 & & $188-198$ & Ch. 1 & & 188-198 & $\begin{array}{l}\text { zerofiles 188-191, no } \\
\text { lines 1-4 }\end{array}$ & USGS DAT6 & $1-11$ & zerofiles $1-4$, no lines $1-4$ \\
\hline 1016 & 7069 & & 199-209 & Ch. 1 & & 199-209 & Ch. 1 & & $12-22$ & Ch. 1 \\
\hline 1017 & 7285 & & $210-220$ & Ch. 3 & & $210-220$ & Ch. 3 & USGS DAT7 & $1-11$ & Ch. 3 \\
\hline 1018 & 7083 & USGS DLT2A & $1-11$ & Ch. 1 & USGS DLT2B & $1-11$ & zero file 1 , no line 1 & USGS DAT8 & $1-11$ & zero file 1 , no line 1 \\
\hline 1019 & 7289 & & $12-22$ & Ch. 3 & & $12-22$ & Ch. 3 & USGS DAT9 & $1-11$ & Ch. 3 \\
\hline 1020 & 7286 & & $23-33$ & Ch. 3 & & 23-33 & Ch. 3 & USGS DAT10 & $1-11$ & Ch. 3 \\
\hline 1021 & 7357 & & $34-44$ & $\begin{array}{l}\text { zero files } 35-44 \text {, no } \\
\text { lines } 2-11\end{array}$ & & $34-44$ & $\begin{array}{l}\text { zero files } 35-44 \text {, no lines } \\
2-11\end{array}$ & & $12-22$ & $\begin{array}{l}\text { zero files } 13-22 \text { no lines } 2- \\
11\end{array}$ \\
\hline 1021 & 7357 & & $45-55$ & Ch. 1 & & $45-55$ & Use this version & & $23-33$ & Use this version \\
\hline 1022 & 7345 & & $56-66$ & zero file 56 , no line 1 & & $56-66$ & zero file 56, no line 1 & & $34-44$ & zero file 34 , no line 1 \\
\hline 2001 & 153 & & $67-77$ & All zero files & & $67-77$ & All zero files & USGS DAT11 & $1-11$ & All zero files \\
\hline 2002 & 6032 & & $78-88$ & Ch. 1 & & $78-88$ & Ch. 1 & & $12-22$ & Ch. 1 \\
\hline 2003 & 6021 & & $89-99$ & Ch. 1 & & $89-99$ & Ch. 1 & & $23-33$ & Ch. 1 \\
\hline
\end{tabular}




\begin{tabular}{|c|c|c|c|c|c|c|c|c|c|c|}
\hline 2004 & 7593 & & $100-110$ & All zero files & & $100-110$ & All zero files & & $34-44$ & All zero files \\
\hline 2005 & 6047 & & $111-121$ & Ch. 1 & & $111-121$ & Ch. 1 & & $45-55$ & Ch. 1 \\
\hline 2006 & 7300 & & $122-132$ & Ch. 1 & & $122-132$ & Ch. 1 & & 56-66 & Ch. 1 \\
\hline 2007 & 6122 & & $133-143$ & Ch. 1 & & 133-143 & Ch. 1 & & $67-77$ & Ch. 1 \\
\hline 2008 & 6093 & & 144-154 & Ch. 1 & & 144-154 & Ch. 1 & USGS DAT12 & $1-11$ & Ch. 1 \\
\hline 2009 & 6031 & & $155-165$ & Ch. 1 & & $155-165$ & Ch. 1 & & $12-22$ & Ch. 1 \\
\hline 2010 & 6087 & & $166-176$ & Ch. 1 & & $166-176$ & Ch. 1 & & $23-33$ & Ch. 1 \\
\hline 2011 & 359 & & $177-187$ & Ch. 4 & & $177-187$ & Ch. 4 & & $34-44$ & Ch. 4 \\
\hline 2012 & 149 & & $188-198$ & Ch. 4 & & $188-198$ & Ch. 4 & USGS DAT13 & $1-11$ & Ch. 4 \\
\hline 2013 & 340 & USGS DLT3A & $1-11$ & Ch. 4 & USGS DLT3B & $1-11$ & Ch. 4 & USGS DAT14 & $1-11$ & Ch. 4 \\
\hline 2014 & 6071 & copy of & $12-22$ & Ch. 1 & & $12-22$ & Ch. 1 & & $12-22$ & Ch. 1 \\
\hline 3001 & 6057 & USGS DLT3B & $23-33$ & Ch. 1 & & $23-33$ & Ch. 1 & & $23-33$ & Ch. 1 \\
\hline 3002 & 529 & & $34-44$ & $\begin{array}{l}\text { zerofile } 44 \text {, no line } 11 \text {, } \\
\text { Ch. } 4\end{array}$ & & $34-44$ & zerofile 44 , no line 11 & & $34-44$ & zerofile 44 , no line 11 \\
\hline 3003 & 6081 & & $45-55$ & Ch. 1 & & $45-55$ & Ch. 1 & USGS DAT15 & $1-11$ & Ch. 1 \\
\hline 3004 & 6125 & & $56-66$ & Ch. 1 & & $56-66$ & Ch. 1 & & $12-22$ & Ch. 1 \\
\hline 3005 & 7044 & & $67-77$ & Ch. 1 & & $67-77$ & Ch. 1 & & $23-33$ & Ch. 1 \\
\hline 3006 & 880 & & $78-88$ & Ch. 4 & & $78-88$ & Ch. 4 & & $34-44$ & Ch. 4 \\
\hline 3008 & 7058 & & $89-99$ & Ch. 1 & & $89-99$ & Ch. 1 & USGS DAT16 & $1-11$ & Ch. 1 \\
\hline 3007 & 7064 & & $100-110$ & Ch. 1 & & $100-110$ & Ch. 1 & & $12-22$ & Ch. 1 \\
\hline 3009 & 348 & & $111-121$ & Ch. 4 & & $111-121$ & Ch. 4 & USGS DAT17 & $1-11$ & Ch. 4 \\
\hline 3010 & 7081 & & $122-132$ & on DLT3A & & $122-132$ & on DLT3A & & $12-22$ & on DLT3A \\
\hline 3011 & 6045 & & $133-143$ & Ch. 1 & & $133-143$ & Ch. 1 & & $23-33$ & Ch. 1 \\
\hline 3012 & 7283 & & $144-154$ & Ch. 1 & & $144-154$ & Ch. 1 & USGS DAT18 & $1-11$ & Ch. 1 \\
\hline 3013 & 7362 & & $155-165$ & Ch. 1 & & $155-165$ & Ch. 1 & USGS DAT19 & $1-11$ & Ch. 1 \\
\hline 3014 & 7597 & & $166-176$ & Ch. 1 & & $166-176$ & Ch. 1 & & $12-22$ & Ch. 1 \\
\hline 4001 & 898 & & $177-187$ & Ch. 4 & & $177-187$ & Ch. 4 & USGS DAT20 & $1-11$ & Ch. 4 \\
\hline 4002 & 7066 & USGS DLT4A & $1-11$ & Ch. 1 & USGS DLT4B & $1-11$ & Ch. 1 & & $12-22$ & Ch. 1 \\
\hline 4003 & 7288 & & $12-22$ & Ch. 1 & & $12-22$ & Ch. 1 & & $23-33$ & Ch. 1 \\
\hline 4004 & 6066 & & $23-33$ & $\begin{array}{l}\text { zero files } 23-25, \text { no } \\
\text { lines } 1-3\end{array}$ & & $23-33$ & $\begin{array}{l}\text { zero files } 23-25, \text { no lines } \\
1-3\end{array}$ & USGS DAT21 & $1-11$ & zero files $1-3$, no lines $1-3$ \\
\hline 4006 & 7112 & & $34-44$ & $\begin{array}{l}\text { zero files } 41-44, \text { no } \\
\text { lines } 8-11\end{array}$ & & $34-44$ & $\begin{array}{l}\text { zero files } 41-44, \text { no lines } \\
8-11\end{array}$ & & $12-22$ & $\begin{array}{l}\text { zero files } 19-22, \text { no lines } \\
8-11\end{array}$ \\
\hline 4007 & 7282 & & $45-55$ & Ch. 1 & & $45-55$ & Ch. 1 & & $23-33$ & Ch. 1 \\
\hline 4008 & 7063 & & $56-66$ & Ch. 1 & & $56-66$ & Ch. 1 & USGS DAT22A & $1-11$ & Ch. 1 \\
\hline 4009 & 7110 & & $67-77$ & Ch. 1 & & $67-77$ & Ch. 1 & & $12-22$ & Ch. 1 \\
\hline 4010 & 6020 & & $78-88$ & Ch. 1 & & $78-88$ & Ch. 1 & & $23-33$ & Ch. 1 \\
\hline 4011 & 6108 & & $89-99$ & Ch. 1 & & $89-99$ & Ch. 1 & & $34-44$ & Ch. 1 \\
\hline 4013 & 6085 & & $100-110$ & $\begin{array}{l}\text { zero files } 100-102, \text { no } \\
\text { line } 1-3\end{array}$ & & $100-110$ & $\begin{array}{l}\text { zero files } 100-102 \text {, no } \\
\text { line } 1-3\end{array}$ & USGS DAT22B & $1-11$ & zerofiles $1-3$, no lines $1-3$ \\
\hline 5001 & 7107 & & $111-121$ & $\begin{array}{l}\text { zero file } 113, \text { missed } \\
\text { line } 1-5 \text { data }\end{array}$ & & $111-121$ & $\begin{array}{l}\text { zero file } 113, \text { missed } \\
\text { line } 1-5 \text { data }\end{array}$ & & $12-22$ & Ch. 1 , missed line 1-5 data \\
\hline
\end{tabular}




\begin{tabular}{|c|c|c|c|c|c|c|c|c|c|c|}
\hline 5002 & 895 & & $122-132$ & Ch. 4 & & $122-132$ & Ch. 4 & & $23-33$ & Ch. 1 \\
\hline 5003 & 395 & & $133-143$ & Ch. 4 & & $133-143$ & Ch. 4 & USGS DAT23 & $1-11$ & Ch. 1 \\
\hline 5004 & 6025 & & $144-154$ & $\begin{array}{l}\text { zero files 144-146, } \\
\text { missed line 1-5 data }\end{array}$ & & $144-154$ & $\begin{array}{l}\text { zero files 144-146, } \\
\text { missed line 1-5 data }\end{array}$ & & $12-22$ & Ch. 1, zerofiles $12-14$, \\
\hline 5005 & 7077 & & $155-165$ & Ch. 1 & & $155-165$ & Ch. 1 & USGS DAT24 & $1-11$ & Ch. 1 \\
\hline 5001 & 7107 & & $166-176$ & Use this gather! & & $166-176$ & Use this gather! - ch. 1 & & $12-22$ & Use this gather! Ch. 1 \\
\hline 5004 & 6025 & & $177-187$ & Use this gather! & & $177-187$ & Use this gather! - Ch. 1 & & $23-33$ & Use this gather! Ch. 1 \\
\hline 5006 & 7039 & USGS DLT5A & $1-11$ & Ch. 1 & USGS DLT5B & $1-11$ & Ch. 1 & USGS DAT25 & $1-11$ & Ch. 1 \\
\hline 5007 & 877 & & $12-22$ & All zero files & & $12-22$ & All zero files & & $12-22$ & All zero files \\
\hline 5007 & 877 & & $23-33$ & $\begin{array}{l}\text { zero files } 27-33 \text {, no } \\
\text { lines } 5-11, \text { Ch. } 4 \\
\end{array}$ & & $23-33$ & $\begin{array}{l}\text { zero files } 27-33 \text {, no lines } \\
5-11\end{array}$ & & $23-33$ & $\begin{array}{l}\text { zero files } 27-33 \text {, no lines } \\
5-11\end{array}$ \\
\hline 5008 & 369 & & $34-44$ & Ch. 4 & & $34-44$ & Ch. 4 & & $34-44$ & Ch. 1 \\
\hline 5009 & 656 & & $45-55$ & All zero files & & $45-55$ & All zero files & USGS DAT26 & $1-11$ & All zero files \\
\hline 5009 & 656 & & $56-66$ & Ch. 4 & & $56-66$ & Ch. 4 & & $12-22$ & Ch. 1 \\
\hline 6001 & 7291 & & $67-77$ & Ch. 1 & & $67-77$ & Ch. 1 & & $23-33$ & Ch. 1 \\
\hline 6002 & 6084 & & $78-88$ & Ch. 1 & & $78-88$ & Ch. 1 & & $34-44$ & Ch. 1 \\
\hline 6003 & 6080 & & $89-99$ & Ch. 1 & & $89-99$ & Ch. 1 & & $45-55$ & Ch. 1 \\
\hline 6004 & 7595 & & $100-110$ & Ch. 1 & & $100-110$ & Ch. 1 & USGS DAT27 & $1-11$ & Ch. 1 \\
\hline 6005 & 6051 & & $111-121$ & Ch. 1 & & $111-121$ & Ch. 1 & & $12-22$ & Ch. 1 \\
\hline 6006 & 6098 & & $122-132$ & Ch. 1 & & $122-132$ & Ch. 1 & & $23-33$ & Ch. 1 \\
\hline 6007 & 7448 & & $133-143$ & Ch. 1 & & $133-143$ & Ch. 1 & & $34-44$ & Ch. 1 \\
\hline 6008 & 7444 & & $144-154$ & Ch. 1 & & $144-154$ & Ch. 1 & USGS DAT28 & $1-11$ & Ch. 1 \\
\hline 6009 & 7605 & & $155-165$ & Ch. 1 & & $155-165$ & Ch. 1 & & $12-22$ & Ch. 1 \\
\hline 6010 & 6114 & & $166-176$ & zero file 166 , no line 1 & & $166-176$ & zero file 166 , no line 1 & & $23-33$ & $\begin{array}{l}\text { Ch. 1, zerofile } 23 \text {, no line } \\
1\end{array}$ \\
\hline 6011 & 7615 & & $177-187$ & Ch. 1 & & $177-187$ & Ch. 1 & USGS DAT29 & $1-11$ & Ch. 1 \\
\hline
\end{tabular}




\begin{tabular}{|c|c|c|c|c|c|c|c|c|c|c|}
\hline 6012 & 7594 & & $188-198$ & Ch. 1 & & $188-198$ & Ch. 1 & & $12-22$ & Ch. 1 \\
\hline 6013 & 6019 & & 199-209 & Ch. 1 & & $199-209$ & Ch. 1 & & $23-33$ & Ch. 1 \\
\hline 6014 & 6067 & & $210-220$ & Ch. 1 & & $210-220$ & Ch. 1 & & $34-44$ & Ch. 1 \\
\hline 1004 & 7278 & USGS DLT6A & $1-11$ & Ch. 1 & USGS DLT6B & $1-11$ & Ch. 1 & USGS DAT30 & $1-11$ & Ch. 1 \\
\hline 1007 & 6097 & & $12-22$ & All Zero files & & $12-22$ & All Zero files & & $12-22$ & All Zero files \\
\hline 1009 & 6062 & & $23-33$ & $\begin{array}{l}\text { zero files 23-24, no } \\
\text { lines 1-2 }\end{array}$ & & $23-33$ & $\begin{array}{l}\text { zero files } 23-24, \text { no lines } \\
1-2\end{array}$ & & $23-33$ & zero files $23-24$, no lines $1-2$ \\
\hline 1007 & 6097 & & $34-44$ & $\begin{array}{l}\text { zero files } 34-35, \text { no } \\
\text { lines } 1-2\end{array}$ & & $34-44$ & $\begin{array}{l}\text { zero files } 34-35, \text { no lines } \\
1-2\end{array}$ & & $34-44$ & zero files $34-35$, no lines $1-2$ \\
\hline 1011 & 7602 & & $45-55$ & Ch. 1 & & $45-55$ & Ch. 1 & USGS DAT31 & $1-11$ & Ch. 1 \\
\hline 1012 & 6056 & & $56-66$ & Ch. 1 & & $56-66$ & Ch. 1 & & $12-22$ & Ch. 1 \\
\hline 1013 & 6121 & & $67-77$ & Ch. 1 & & $67-77$ & Ch. 1 & & $23-33$ & Ch. 1 \\
\hline 1014 & 7298 & & $78-88$ & Ch. 1 & & $78-88$ & Ch. 1 & & 34-44 & Ch. 1 \\
\hline 1015 & 6086 & & $89-99$ & Ch. 1 & & 89-99 & Ch. 1 & USGS DAT32 & $1-11$ & Ch. 1 \\
\hline 1017 & 7285 & & $100-110$ & Ch. 1 & & $100-110$ & Ch. 1 & & $12-22$ & Ch. 1 \\
\hline 1019 & 7289 & & $111-121$ & Ch. 1 & & $111-121$ & Ch. 1 & & $23-33$ & Ch. 1 \\
\hline 1020 & 7286 & & $122-132$ & Ch. 1 & & $122-132$ & Ch. 1 & USGS DAT33 & $1-11$ & Ch. 1 \\
\hline 2001 & 153 & & $133-143$ & Ch. 4 & & 133-143 & Ch. 4 & & $12-22$ & Ch. 1 \\
\hline 2002 & 6032 & & 144-154 & Ch. 1 & & 144-154 & Ch. 1 & & $23-33$ & Ch. 1 \\
\hline 2003 & 6021 & & $155-165$ & Ch. 1 & & $155-165$ & Ch. 1 & & $34-44$ & Ch. 1 \\
\hline 2004 & 7593 & & $166-176$ & $\begin{array}{l}\text { zero files } 169,174-176 \text {, } \\
\text { no line } 4,9-11\end{array}$ & & $166-176$ & $\begin{array}{l}\text { zero files } 169,174-176 \text {, } \\
\text { no line } 4,9-11\end{array}$ & USGS DAT34 & $1-11$ & $\begin{array}{l}\text { Ch. 1, zerofiles 4, 9-11, no } \\
\text { lines 4, 9-11 }\end{array}$ \\
\hline 2004 & 6091 & & $177-187$ & $\begin{array}{l}\text { zero files } 177-179,182- \\
187, \text { partial line } 5 \text { only }\end{array}$ & & $177-187$ & $\begin{array}{l}\text { zero files } 177-179,182- \\
187, \text { partial line } 5 \text { only }\end{array}$ & & $12-22$ & $\begin{array}{l}\text { Ch. 1, zerofiles 12-14, 17- } \\
22,\end{array}$ \\
\hline 2004 & 6088 & & $188-198$ & $\begin{array}{l}\text { zero flles } 188-192, \text { no } \\
\text { lines 1-5 }\end{array}$ & & $188-198$ & $\begin{array}{l}\text { zero flles } 188-192, \text { no } \\
\text { lines } 1-5\end{array}$ & & $23-33$ & $\begin{array}{l}\text { Ch. 1, zerofiles 23-27, no } \\
\text { lines 1-5 }\end{array}$ \\
\hline 2005 & 6047 & & 199-209 & Ch. 1 & & 199-209 & Ch. 1 & USGS DAT35 & $1-11$ & Ch. 1 \\
\hline 2007 & 6122 & & $210-220$ & Ch. 1 & & $210-220$ & Ch. 1 & & $12-22$ & Ch. 1 \\
\hline 2008 & 6093 & & $221-231$ & Ch. 1 & & $221-231$ & Ch. 1 & & $23-33$ & Ch. 1 \\
\hline 2010 & 6087 & & $232-242$ & Ch. 1 & & $232-242$ & Ch. 1 & & $34-44$ & Ch. 1 \\
\hline 2012 & 6064 & & $243-253$ & $\begin{array}{l}\text { zero files } 243-244,249- \\
250, \text { no lines } 1-2,7-8\end{array}$ & & $243-253$ & $\begin{array}{l}\text { zero files } 243-244,249- \\
250, \text { no lines } 1-2,7-8\end{array}$ & & $45-55$ & Ch. 1 , zerofiles $45-46,51-52$ \\
\hline 3010 & 7081 & USGS DLT7A & $1-11$ & Ch. 1 & USGS DLT7B & $1-11$ & Ch. 1 & USGS DAT36 & $1-11$ & Ch. 1 \\
\hline 4004 & 7078 & & $12-22$ & $\begin{array}{l}\text { zero files } 16-22, \text { no } \\
\text { lines } 5-11\end{array}$ & & $12-22$ & $\begin{array}{l}\text { zero files } 16-22, \text { no lines } \\
5-11\end{array}$ & USGS DAT37 & $1-11$ & $\begin{array}{l}\text { Ch. 1, zerofiles 5-11, no } \\
\text { lines 5-11 }\end{array}$ \\
\hline 4006 & 6120 & & $23-33$ & $\begin{array}{l}\text { zero files 23-27, no } \\
\text { lines 1-5 }\end{array}$ & & $23-33$ & $\begin{array}{l}\text { zero files } 23-27 \text {, no lines } \\
1-5\end{array}$ & & $12-22$ & $\begin{array}{l}\text { Ch. 1, zerofiles 12-16, no } \\
\text { lines 1-5 }\end{array}$ \\
\hline 4011 & 6108 & & $34-44$ & Ch. 1 & & $34-44$ & Ch. 1 & USGS DAT38 & $1-11$ & Ch. 1 \\
\hline 4012 & 6037 & & $45-55$ & Ch. 1 & & $45-55$ & Ch. 1 & USGS DAT39 & $1-11$ & Ch. 1 \\
\hline 4013 & 6085 & & $56-66$ & $\begin{array}{l}\text { zero files } 56-58, \text { no } \\
\text { lines } 1-3\end{array}$ & & $56-66$ & $\begin{array}{l}\text { zero files } 56-58, \text { no lines } \\
1-3\end{array}$ & USGS DAT40 & $1-11$ & $\begin{array}{l}\text { Ch. 1, zerofiles 1-3, no lines } \\
1-3\end{array}$ \\
\hline 5005 & 6025 & & $67-77$ & Ch. 1 & & $67-77$ & Ch. 1 & USGS DAT41 & $1-11$ & Ch. 1 \\
\hline
\end{tabular}




\begin{tabular}{|c|c|c|c|c|c|c|c|c|c|c|}
\hline 5009 & 656 & & $78-88$ & Ch. 4 & & $78-88$ & Ch. 4 & USGS DAT42 & $1-11$ & Ch. 1 \\
\hline 7001 & 7056 & & $89-99$ & Ch. 1 & & $89-99$ & Ch. 1 & USGS DAT43 & $1-11$ & Ch. 1 \\
\hline 7002 & 7604 & & $100-110$ & Ch. 1 & & $100-110$ & Ch. 1 & USGS DAT44 & $1-11$ & Ch. 1 \\
\hline 7003 & 7052 & & $111-121$ & Ch. 1 & & $111-121$ & Ch. 1 & USGS DAT45 & $1-11$ & Ch. 1 \\
\hline 7004 & 7306 & & $122-132$ & Ch. 1 & & $122-132$ & Ch. 1 & USGS DAT46 & $1-11$ & Ch. 1 \\
\hline 7005 & 6090 & & $133-143$ & Ch. 1 & & $133-143$ & Ch. 1 & USGS DAT47 & $1-11$ & Ch. 1 \\
\hline 7006 & 7070 & & $144-154$ & $\begin{array}{l}\text { zero files } 144,146-154, \\
\text { have only line } 2\end{array}$ & & $144-154$ & $\begin{array}{l}\text { zero files } 144,146-154, \\
\text { have only line } 2\end{array}$ & & $12-22$ & $\begin{array}{l}\text { Ch. 1, zerofile } 12,14-22, \\
\text { have only line } 2\end{array}$ \\
\hline 7006 & 6102 & & $155-165$ & zero file 155, no line 1 & & $155-165$ & zero file 155 , no line 1 & & $23-33$ & Ch. 1 , zerofile 23 , no line 1 \\
\hline 7007 & 6042 & & $166-176$ & zero file 166, no line 1 & & $166-176$ & zero file 166, no line 1 & USGS DAT48 & $1-11$ & Ch. 1 , zerofile 1 , no line 1 \\
\hline 7008 & 7292 & & $177-187$ & Ch. 1 & & $177-187$ & Ch. 1 & & $12-22$ & Ch. 1 \\
\hline 7009 & 381 & & $188-198$ & Ch. 4 & & $188-198$ & Ch. 4 & USGS DAT49 & $1-11$ & Ch. 1 \\
\hline 7010 & 7316 & & 199-209 & Ch. 1 & & 199-209 & Ch. 1 & USGS DAT50 & $1-11$ & Ch. 1 \\
\hline 7011 & 7085 & USGS DLT8A & $1-11$ & Ch. 1 & USGS DLT8B & $1-11$ & Ch. 1 & USGS DAT51 & $1-11$ & Ch. 1 \\
\hline 8001 & 6092 & & $12-22$ & Ch. 1 & & $12-22$ & Ch. 1 & USGS DAT52 & $1-11$ & Ch. 1 \\
\hline 8003 & 7614 & & $23-33$ & Ch. 1 & & $23-33$ & Ch. 1 & USGS DAT53 & $1-11$ & Ch. 1 \\
\hline 7012 & 6107 & & $34-44$ & $\begin{array}{l}\text { zero files } 34-37,43 \text {, no } \\
\text { lines } 1-4,10\end{array}$ & & $34-44$ & $\begin{array}{l}\text { zero files } 34-37,43, \text { no } \\
\text { lines } 1-4,10\end{array}$ & & $12-22$ & $\begin{array}{l}\text { Ch. 1, zerofiles 12-15, } 21 \text {, } \\
\text { no lines 1-4 }\end{array}$ \\
\hline 8002 & 6040 & & $45-55$ & Ch. 1 & & $45-55$ & Ch. 1 & USGS DAT54 & $1-11$ & Ch. 1 \\
\hline 8004 & 6101 & & $56-66$ & Ch. 1 & & 56-66 & Ch. 1 & & $12-22$ & Ch. 1 \\
\hline 8005 & 6118 & & $67-77$ & Ch. 1 & & $67-77$ & Ch. 1 & & $23-33$ & Ch. 1 \\
\hline 8006 & 7303 & & $78-88$ & Ch. 1 & & 78-88 & Ch. 1 & USGS DAT55 & $1-11$ & Ch. 1 \\
\hline 8007 & 6065 & & $89-99$ & Ch. 1 & & $89-99$ & Ch. 1 & & $12-22$ & Ch. 1 \\
\hline 8008 & 7330 & & $100-110$ & Ch. 1 & & $100-110$ & Ch. 1 & USGS DAT56 & $1-11$ & Ch. 1 \\
\hline 8009 & 7630 & & $111-121$ & Ch. 1 & & $111-121$ & Ch. 1 & USGS DAT57 & $1-11$ & Ch. 1 \\
\hline 8010 & 7320 & & $122-132$ & Ch. 1 & & $122-132$ & Ch. 1 & USGS DAT58 & $1-11$ & Ch. 1 \\
\hline 8011 & 7460 & & $133-143$ & Ch. 1 & & $133-143$ & Ch. 1 & USGS DAT59 & $1-11$ & Ch. 1 \\
\hline 8012 & 7295 & & 144-154 & Ch. 1 & & 144-154 & Ch. 1 & USGS DAT60 & $1-11$ & Ch. 1 \\
\hline 8013 & 7462 & & $155-165$ & Ch. 1 & & $155-165$ & Ch. 1 & USGS DAT61 & $1-11$ & Ch. 1 \\
\hline 8014 & 7440 & & $166-176$ & Ch. 1 & & 166-176 & Ch. 1 & USGS DAT62 & $1-11$ & Ch. 1 \\
\hline 4003 & 7288 & USGS DLT9A & $1-11$ & Ch. 2 & USGS DLT9B & $1-11$ & Ch. 2 & USGS DAT63 & $1-11$ & Ch. 2 \\
\hline 4003 & 7288 & & $12-22$ & Ch. 3 & & $12-22$ & Ch. 3 & & $12-22$ & Ch. 3 \\
\hline 4007 & 7282 & & $23-33$ & Ch. 2 & & 23-33 & Ch. 2 & & $23-33$ & Ch. 2 \\
\hline 4007 & 7282 & & $34-44$ & Ch. 3 & & $34-44$ & Ch. 3 & USGS DAT64 & $1-11$ & Ch. 3 \\
\hline 5002 & 895 & & $45-66$ & Ch. 5 and 6 & & $45-66$ & Ch. 5 and 6 & & $12-33$ & Ch. 5 and 6 \\
\hline 5003 & 395 & & $67-88$ & Ch. 5 and 6 & & $67-88$ & Ch. 5 and 6 & USGS DAT65 & $1-22$ & Ch. 5 and 6 \\
\hline 5007 & 877 & Ch. 5 and 6 & $89-110$ & $\begin{array}{l}\text { zerofiles } 97-110, \text { no } \\
\text { lines } 5-11, \text { Ch. } 5 \text { and } 6\end{array}$ & & $89-110$ & $\begin{array}{l}\text { zerofiles } 97-110, \text { no } \\
\text { lines } 5-11, \text { Ch. } 5 \text { and } 6\end{array}$ & & $23-44$ & $\begin{array}{l}\text { zerofiles } 31-44 \text { no lines } 5- \\
11, \text { Ch. } 5 \text { and } 6\end{array}$ \\
\hline 5008 & 369 & & $111-132$ & Ch. 5 and 6 & & 111-132 & Ch. 5 and 6 & USGS DAT66 & $1-22$ & Ch. 5 and 6 \\
\hline 5009 & 656 & & $133-154$ & Ch. 5 and 6 & & $133-154$ & Ch. 5 and 6 & USGS DAT67 & $1-22$ & Ch. 5 and 6 \\
\hline 6001 & 7291 & & $155-176$ & Ch. 2 and 3 & & $155-176$ & Ch. 2 and 3 & USGS DAT68 & $1-22$ & Ch. 2 and 3 \\
\hline 6004 & 7595 & USGS DLT10A & $1-22$ & Ch. 2 and 3 & USGS DLT10B & $1-22$ & Ch. 2 and 3 & USGS DAT69 & $1-22$ & Ch. 2 and 3 \\
\hline
\end{tabular}




\begin{tabular}{|c|c|c|c|c|c|c|c|c|c|c|}
\hline 6009 & 7605 & & $23-44$ & Ch. 2 and 3 & & $23-44$ & Ch. 2 and 3 & USGS DAT70 & $1-22$ & Ch. 2 and 3 \\
\hline 6011 & 7615 & & $45-66$ & Ch. 2 and 3 & & $45-66$ & Ch. 2 and 3 & USGS DAT71 & $1-22$ & Ch. 2 and 3 \\
\hline 6012 & 7594 & & $67-88$ & Ch. 2 and 3 & & $67-88$ & Ch. 2 and 3 & USGS DAT72 & $1-22$ & Ch. 2 and 3 \\
\hline 7002 & 7604 & & $89-110$ & Ch. 2 and 3 & & $89-110$ & Ch. 2 and 3 & USGS DAT73 & $1-22$ & Ch. 2 and 3 \\
\hline 7004 & 7306 & & $111-132$ & Ch. 2 and 3 & & 111-132 & Ch. 2 and 3 & USGS DAT74 & $1-22$ & Ch. 2 and 3 \\
\hline 7009 & 381 & & 133-154 & Ch. 5 and 6 & & 133-154 & Ch. 5 and 6 & USGS DAT75 & $1-22$ & Ch. 5 and 6 \\
\hline 7010 & 7316 & & $155-176$ & Ch. 2 and 3 & & $155-176$ & Ch. 2 and 3 & USGS DAT76 & $1-22$ & Ch. 2 and 3 \\
\hline 8003 & 7614 & USGS DLT11A & $1-22$ & Ch. 2 and 3 & USGS DLT11B & $1-22$ & Ch. 2 and 3 & USGS DAT77 & $1-22$ & Ch. 2 and 3 \\
\hline 8006 & 7303 & & $23-44$ & Ch. 2 and 3 & & $23-44$ & Ch. 2 and 3 & USGS DAT78 & $1-22$ & Ch. 2 and 3 \\
\hline 8009 & 7630 & & $45-66$ & Ch. 2 and 3 & & $45-66$ & Ch. 2 and 3 & USGS DAT79 & $1-22$ & Ch. 2 and 3 \\
\hline 8012 & 7295 & & $67-88$ & Ch. 2 and 3 & & $67-88$ & Ch. 2 and 3 & USGS DAT80 & $1-22$ & Ch. 2 and 3 \\
\hline 1004 & 7278 & & $89-110$ & Ch. 2 and 3 & & $89-110$ & Ch. 2 and 3 & USGS DAT81 & $1-22$ & Ch. 2 and 3 \\
\hline 1008 & 550 & & $111-143$ & Ch. $4,5,6$ & & 111-143 & Ch. $4,5,6$ & USGS DAT82 & $1-33$ & Ch. $4,5,6$ \\
\hline 1011 & 7602 & & $144-165$ & Ch. 2 and 3 & & 144-165 & Ch. 2 and 3 & USGS DAT83 & $1-22$ & Ch. 2 and 3 \\
\hline 1014 & 7298 & USGS DLT12A & $1-22$ & Ch. 2 and 3 & USGS DLT12B & $1-22$ & Ch. 2 and 3 & USGS DAT84 & $1-22$ & Ch. 2 and 3 \\
\hline 1017 & 7285 & & $23-44$ & Ch. 2 and 3 & & $23-44$ & Ch. 2 and 3 & USGS DAT85 & $1-22$ & Ch. 2 and 3 \\
\hline 1019 & 7289 & & $45-66$ & Ch. 2 and 3 & & $45-66$ & Ch. 2 and 3 & USGS DAT86 & $1-22$ & Ch. 2 and 3 \\
\hline 1020 & 7286 & & $67-88$ & Ch. 2 and 3 & & $67-88$ & Ch. 2 and 3 & USGS DAT87 & $1-22$ & Ch. 2 and 3 \\
\hline 2001 & 153 & & $89-110$ & Ch. 5 and 6 & & $89-110$ & Ch. 5 and 6 & USGS DAT88 & $1-22$ & Ch. 5 and 6 \\
\hline 2004 & 7593 & & $111-132$ & $\begin{array}{l}\text { zerofiles } 117-118,127- \\
132, \text { Ch. } 2 \text { and } 3\end{array}$ & & $111-132$ & $\begin{array}{l}\text { zerofiles } 117-118,127- \\
132, \text { Ch. } 2 \text { and } 3\end{array}$ & USGS DAT89 & $1-22$ & $\begin{array}{l}\text { zerofiles 117-118, 127-132, } \\
\text { Ch. } 2 \text { and } 3\end{array}$ \\
\hline 2006 & 7300 & & $133-154$ & Ch. 2 and 3 & & $133-154$ & Ch. 2 and 3 & USGS DAT90 & $1-22$ & Ch. 2 and 3 \\
\hline 2011 & 359 & & $155-176$ & Ch. 5 and 6 & & $155-176$ & Ch. 5 and 6 & USGS DAT91 & $1-22$ & Ch. 5 and 6 \\
\hline 2012 & 149 & USGS DLT13A & $1-22$ & Ch. 5 and 6 & USGS DLT13B & $1-22$ & Ch. 5 and 6 & USGS DAT92 & $1-22$ & Ch. 5 and 6 \\
\hline 2013 & 340 & & $23-44$ & Ch. 5 and 6 & & $23-44$ & Ch. 5 and 6 & USGS DAT93 & $1-22$ & Ch. 5 and 6 \\
\hline 3002 & 529 & & $45-77$ & Ch. $4,5,6$ & & $45-77$ & Ch. 4, 5,61 & USGS DAT94 & $1-33$ & Ch. $4,5,6$ \\
\hline 3006 & 880 & & $78-110$ & zerofiles $75-77$, Ch. 4-6 & & $78-110$ & zerofiles 75-77, Ch. 4-6 & USGS DAT95 & $1-33$ & zerofiles 1-3, Ch. 4-6 \\
\hline 3009 & 348 & & $111-132$ & Ch. 2 and 3 & & $111-132$ & Ch. 2 and 3 & USGS DAT96 & $1-22$ & Ch. 2 and 3 \\
\hline 3012 & 7283 & & $133-154$ & Ch. 2 and 3 & & $133-154$ & Ch. 2 and 3 & USGS DAT97 & $1-22$ & Ch. 2 and 3 \\
\hline 3014 & 7597 & & $155-176$ & Ch. 2 and 3 & & $155-176$ & Ch. 2 and 3 & USGS DAT98 & $1-22$ & Ch. 2 and 3 \\
\hline 4001 & 898 & USGS DLT14A & $1-33$ & Ch. 5 and 6 & USGS DLT14B & $1-33$ & Ch. 5 and 6 & USGS DAT99 & $1-22$ & Ch. 5 and 6 \\
\hline 1003 & 6041 & & $34-44$ & Ch. $1-$ & & $34-44$ & Ch. 1 - fix12secbug & USGS DAT100 & $1-11$ & Ch. 1 - fix 12 secbug \\
\hline 2002 & 6032 & & $45-55$ & Ch. 1 - fix 1988 & & $45-55$ & Ch. 1 - fix 1988 & & $12-22$ & Ch. 1 - fix 1988 \\
\hline 2003 & 6021 & & $56-66$ & Ch. 1 - fix 1988 & & $56-66$ & Ch. 1 - fix 1988 & & $23-33$ & Ch. 1 - fix 1988 \\
\hline 2005 & 6047 & & $67-77$ & Ch. 1 - fix 1988 & & $67-77$ & Ch. 1 - fix 1988 & & $34-44$ & Ch. 1 - fix 1988 \\
\hline 3001 & 6057 & & $78-88$ & Ch. 1 - manual refrate & & $78-88$ & $\begin{array}{l}\text { Ch. } 1 \text { - manual refrate, } \\
\text { fix } 12 \text { secbug }\end{array}$ & & $45-55$ & $\begin{array}{l}\text { Ch. } 1 \text { - manual refrate, } \\
\text { fix } 12 \text { secbug }\end{array}$ \\
\hline 3003 & 6081 & & $89-99$ & Ch. 1 - manual refrate & & $89-99$ & Ch. 1 - manual refrate & & $56-66$ & Ch. 1 - manual refrate \\
\hline 3004 & 6125 & & $100-110$ & Ch. 1 - manual refrate & & $100-110$ & Ch. 1 - manual refrate & USGS DAT101 & $1-11$ & Ch. 1 - manual refrate \\
\hline 4005 & 7100 & & $111-121$ & Ch. 1 & & $111-121$ & Ch. 1 & & $12-22$ & Ch. 1 \\
\hline 4011 & 6108 & & $122-132$ & Ch. 1 & & $122-132$ & Ch. 1 & USGS DAT104 & & Ch. 1 \\
\hline 6003 & 6080 & & $133-143$ & Ch. 1 & & $133-143$ & Ch. 1 & & & Ch. 1 \\
\hline
\end{tabular}




\begin{tabular}{|c|c|c|c|c|c|c|c|c|c|c|}
\hline 1003 & 6041 & & $144-145$ & Lines 4 and 9 & & 144-145 & Lines 4 and 9 & USGS DAT103 & $1-2$ & Lines 4 and 9 \\
\hline 3001 & 6057 & & $146-147$ & Lines 4 and 9 & & $146-147$ & Lines 4 and 9 & & $3-4$ & Lines 4 and 9 \\
\hline 3002 & 529 & & 148-150 & Line 4, Ch. 4-6 & & $148-150$ & Line 4, Ch. 4-6 & & $5-7$ & Line 4, Ch. 4-6 \\
\hline 4012 & 6037 & & 151 & Line 9 & & 151 & Line 9 & & 8 & Line 9 \\
\hline 5004 & 6025 & & 152 & Line 9 & & 152 & Line 9 & & 9 & Line 9 \\
\hline 5009 & 656 & & $153-155$ & Zerofiles & & 153-155 & Zerofiles & & $10-12$ & Zerofiles \\
\hline 5009 & 656 & & 156-158 & Line 9, Ch. 4-6 & & $156-158$ & Line 9, Ch. 4-6 & & $13-15$ & Line 9, Ch. 4-6 \\
\hline 7009 & 381 & OSU DLT4A & $98-100$ & Line 9 & OSU DLT4B & 98-100 & Line 9 & USGS DAT104 & $1-3$ & Line 9 \\
\hline 8007 & 6065 & & 101 & Line 9 & & 101 & Line 9 & & 4 & Line 9 \\
\hline 9001 & 7104 & OSU DLT1A & $1-11$ & Ch. 1 & OSU DLT1B & $1-11$ & Ch. 1 & OSU DAT1 & $1-11$ & Ch. 1 \\
\hline 9003 & 6028 & & $12-22$ & Ch. 1 & & $12-22$ & Ch. 1 & & $12-22$ & Ch. 1 \\
\hline 9002 & 7046 & & $23-33$ & Ch. 1 & & $23-33$ & Ch. 1 & OSU DAT2 & $1-11$ & Ch. 1 \\
\hline 9004 & 7099 & & $34-44$ & $\begin{array}{l}\text { zero files } 39-44, \text { no } \\
\text { lines 6-11 }\end{array}$ & & $34-44$ & $\begin{array}{l}\text { zero files } 39-44, \text { no lines } \\
6-11\end{array}$ & & $12-22$ & $\begin{array}{l}\text { zero files } 17-22 \text { no lines 6- } \\
11\end{array}$ \\
\hline 9005 & 6046 & & $45-55$ & Ch. 1 & & $45-55$ & Ch. 1 & OSU DAT3 & $1-11$ & Ch. 1 \\
\hline 9006 & 7598 & & $56-66$ & Ch. 1 & & $56-66$ & Ch. 1 & & $12-22$ & Ch. 1 \\
\hline 9007 & 7092 & & $67-77$ & Ch. 1 & & $67-77$ & Ch. 1 & OSU DAT4 & $1-11$ & Ch. 1 \\
\hline 9008 & 7072 & & $78-88$ & Ch. 1 & & $78-88$ & Ch. 1 & & $12-22$ & Ch. 1 \\
\hline 9009 & 7116 & & $89-99$ & Ch. 1 & & $89-99$ & Ch. 1 & OSU DAT5 & $1-11$ & Ch. 1 \\
\hline 9010 & 7038 & & $100-110$ & Ch. 1 & & $100-110$ & Ch. 1 & & $12-22$ & Ch. 1 \\
\hline 9011 & 7428 & & 111-121 & Ch. 1 & & $111-121$ & Ch. 1 & OSU DAT6 & $1-11$ & Ch. 1 \\
\hline 9012 & 7466 & & $122-133$ & Ch. 1 & & $122-133$ & Ch. 1 & & $12-23$ & Ch. 1 \\
\hline 9012 & 227 & & $134-144$ & $\begin{array}{l}\text { zero files 134, 139-144, } \\
\text { no lines 1, 6-11 }\end{array}$ & & $134-144$ & $\begin{array}{l}\text { zero files } 134,139-144, \\
\text { no lines } 1,6-11\end{array}$ & OSU DAT7 & $1-11$ & $\begin{array}{l}\text { zero files 1, 6-11, no lines 1, } \\
6-11\end{array}$ \\
\hline 9012 & 6030 & & $145-155$ & $\begin{array}{l}\text { zero files } 145-151, \text { no } \\
\text { lines 1-7 }\end{array}$ & & $145-155$ & $\begin{array}{l}\text { zero files } 145-151 \text {, no } \\
\text { lines 1-7 }\end{array}$ & & $12-22$ & zero files $12-18$, no lines 1-7 \\
\hline 9013 & 7324 & & $156-166$ & Ch. 1 & & $156-166$ & Ch. 1 & OSU DAT8 & $1-11$ & Ch. 1 \\
\hline 9014 & 7296 & & $167-177$ & Ch. 1 & & $167-177$ & Ch. 1 & OSU DAT9 & $1-11$ & Ch. 1 \\
\hline 9015 & 7098 & & $178-188$ & Ch. 1 & & $178-188$ & Ch. 1 & OSU DAT10 & $1-11$ & Ch. 1 \\
\hline 9016 & 7061 & OSU DLT2A & $1-11$ & Ch. 1 & OSU DLT2B & $1-11$ & Ch. 1 & OSU DAT11 & $1-11$ & Ch. 1 \\
\hline 9017 & 7452 & & $12-22$ & Ch. 1 & & $12-22$ & Ch. 1 & OSU DAT12 & $1-11$ & Ch. 1 \\
\hline 9018 & 7302 & & $23-33$ & Ch. 1 & & 23-33 & Ch. 1 & OSU DAT13 & $1-11$ & Ch. 1 \\
\hline 9019 & 7454 & & $34-44$ & Ch. 1 & & $34-44$ & Ch. 1 & OSU DAT14 & $1-11$ & Ch. 1 \\
\hline 9021 & 7352 & & $45-55$ & Ch. 1 & & $45-55$ & Ch. 1 & OSU DAT15 & $1-11$ & Ch. 1 \\
\hline 9022 & 7435 & & $56-66$ & Ch. 1 & & $56-66$ & Ch. 1 & OSU DAT16 & $1-11$ & Ch. 1 \\
\hline 9023 & 338 & & $67-77$ & All Zero files & & $67-77$ & All Zero files & & & \\
\hline \multirow[t]{2}{*}{9023} & 338 & & $78-88$ & Ch. 4 & & $78-88$ & Ch. 4 & OSU DAT17 & $1-11$ & Ch. 4 \\
\hline & & & & & & 89-91 & All Zero files & & & \\
\hline 9024 & 7317 & & $89-99$ & Ch. 1 & & $92-102$ & Ch. 1 & OSU DAT18 & $1-11$ & Ch. 1 \\
\hline 9025 & 7089 & & $100-110$ & zero file 100 , no line 1 & & 103-113 & zero file 100, no line 1 & OSU DAT19 & $1-11$ & zero file 1 , no line 1 \\
\hline 9027 & 7339 & & 111-121 & Ch. 1 & & 114-124 & Ch. 1 & OSU DAT20 & $1-11$ & Ch. 1 \\
\hline 9028 & 7073 & & $122-132$ & Ch. 1 & & $125-135$ & Ch. 1 & OSU DAT21 & $1-11$ & Ch. 1 \\
\hline
\end{tabular}




\begin{tabular}{|c|c|c|c|c|c|c|c|c|c|c|}
\hline 9029 & 771 & & $133-143$ & Ch. 4 & & $136-146$ & Ch. 4 & OSU DAT22 & $1-11$ & Ch. 4 \\
\hline 9030 & 6029 & & $144-154$ & $\begin{array}{l}\text { zero files } 144-148, \text { no } \\
\text { lines } 1-5\end{array}$ & & $147-157$ & $\begin{array}{l}\text { zero files } 147-151 \text {, no } \\
\text { lines } 1-5\end{array}$ & OSU DAT23 & $1-11$ & zero files $1-5$, no lines $1-5$ \\
\hline 9031 & 6026 & & $155-165$ & zero file 155 , no line 1 & & $158-168$ & zero file 158 , no line 1 & OSU DAT24 & $1-11$ & zero file 1, no line 1 \\
\hline 9004 & 6018 & & $166-176$ & $\begin{array}{l}\text { zero files } 166-169 \text {, no } \\
\text { lines 1-4 }\end{array}$ & & $169-179$ & $\begin{array}{l}\text { zero files } 169-172 \text {, no } \\
\text { lines 1-4 }\end{array}$ & OSU DAT25 & $1-11$ & zero files $1-4$, no lines $1-4$ \\
\hline 9012 & 6069 & & $177-187$ & $\begin{array}{l}\text { zero files } 177-181,187 \text {, } \\
\text { no lines } 1-5,11\end{array}$ & & $180-190$ & $\begin{array}{l}\text { zero files } 180-184,190 \text {, } \\
\text { no lines } 1-5,11\end{array}$ & OSU DAT26 & $1-11$ & $\begin{array}{l}\text { zero files } 1-5,11 \text {, no lines } 1- \\
5,11\end{array}$ \\
\hline 9030 & 7075 & OSU DLT3A & $1-11$ & $\begin{array}{l}\text { zero files } 7-11, \text { no lines } \\
\text { 7-11 }\end{array}$ & OSU DLT3B & $1-11$ & $\begin{array}{l}\text { zero files } 7-11 \text {, no lines } \\
7-11\end{array}$ & OSU DAT27 & $1-11$ & zero files $7-11$, no lines $7-11$ \\
\hline 9006 & 7598 & CAN DLT4A & $89-110$ & Ch. 2 and 3 & CAN DLT4B & $89-110$ & Ch. 2 and 3 & OSU DAT2 8 & $1-22$ & Ch. 2 and 3 \\
\hline 9018 & 7302 & & $111-132$ & Ch. 2 and 3 & & $111-132$ & Ch. 2 and 3 & OSU DAT29 & $1-22$ & Ch. 2 and 3 \\
\hline 9023 & 338 & & $133-154$ & Ch. 5 and 6 & & 133-154 & Ch. 5 and 6 & OSU DAT30 & $1-22$ & Ch. 5 and 6 \\
\hline 9008 & 7072 & & $155-187$ & $\begin{array}{l}\text { Zerofiles } 156-157,159- \\
\text { 160, 162-163, 165-166, } \\
\text { 168-169, Ch. 1, 2, } 3 \\
\end{array}$ & & $155-187$ & $\begin{array}{l}\text { Zerofiles } 156-157,159- \\
\text { 160, 162-163, 165-166, } \\
168-169, \text { Ch. } 1,2,3\end{array}$ & OSU DAT31 & $1-22$ & $\begin{array}{l}\text { Zerofiles 2-3, 5-6, 8-9, 11- } \\
12,14-15 \text {, Ch. 1, 2, } 3\end{array}$ \\
\hline 9010 & 7038 & OSU DLT4A & $1-22$ & $\begin{array}{l}\text { Ch. } 2 \text { and 3, Zerofiles } \\
1-8, \text { no lines 1-4 }\end{array}$ & OSU DLT4B & $1-22$ & $\begin{array}{l}\text { Ch. } 2 \text { and 3, Zerofiles 1- } \\
\text { 8, no lines 1-4 }\end{array}$ & OSU DAT32 & $1-22$ & $\begin{array}{l}\text { Ch. } 2 \text { and } 3 \text { Zerofiles 1-8, } \\
\text { no lines 1-4 }\end{array}$ \\
\hline 9011 & 7428 & & $23-44$ & $\begin{array}{l}\text { Ch. } 2 \text { and 3, Zerofiles } \\
\text { 23-30, no lines 1-4 }\end{array}$ & & $23-44$ & $\begin{array}{l}\text { Ch. } 2 \text { and } 3 \text {, Zerofiles } \\
23-30, \text { no lines 1-4 }\end{array}$ & OSU DAT33 & $1-22$ & $\begin{array}{l}\text { Ch. } 2 \text { and } 3 \text { Zerofiles 1-8, } \\
\text { no lines 1-4 }\end{array}$ \\
\hline 9012 & 227 & & $45-66$ & $\begin{array}{l}\text { Ch. } 5 \text { and } 6 \text {, Zerofiles } \\
45-46,55-66 \text {, no lines } \\
1,6-11\end{array}$ & & $45-66$ & $\begin{array}{l}\text { Ch. } 5 \text { and } 6 \text {, Zerofiles } \\
45-46,55-66 \text {, no lines } 1 \text {, } \\
6-11\end{array}$ & OSU DAT34 & $1-22$ & $\begin{array}{l}\text { Ch. } 2 \text { and } 3 \text { Zerofiles 1-2, } \\
\text { 23-30, no lines 1, 6-11 }\end{array}$ \\
\hline 9014 & 7296 & & $67-88$ & $\begin{array}{l}\text { Ch. } 2 \text { and 3, Zerofiles } \\
67-74, \text { no lines 1-4 }\end{array}$ & & $67-88$ & $\begin{array}{l}\text { Ch. } 2 \text { and 3, Zerofiles } \\
67-74, \text { no lines 1-4 }\end{array}$ & & $23-44$ & Zerofiles $23-30$, no lines $1-4$ \\
\hline 9001 & 7104 & & $89-90$ & Lines 4 and 9 & & $89-90$ & Lines 4 and 9 & OSU DAT35 & $1-2$ & Lines 4 and 9 \\
\hline 9008 & 7072 & & $91-94$ & $\begin{array}{l}\text { Line } 4 \text { Ch. 1, Line } 9 \text { Ch. } \\
1-3\end{array}$ & & 91-94 & $\begin{array}{l}\text { Line } 4 \text { Ch. 1, Line } 9 \mathrm{Ch} \text {. } \\
1-3\end{array}$ & & $3-6$ & Line 4 Ch. 1 , Line 9 Ch. 1-3 \\
\hline 9009 & 7116 & & 95 & Line 9 & & 95 & Line 9 & & 7 & Line 9 \\
\hline 9012 & 6030 & & 96 & Line 9 & & 96 & Line 9 & & 8 & Line 9 \\
\hline 9015 & 7098 & & 97 & Line 9 & & 97 & Line 9 & & 9 & Line 9 \\
\hline 7009 & 381 & OSU DLT4A & $98-100$ & Line 9 & OSU DLT4B & $98-100$ & Line 9 & USGS DAT104 & $1-3$ & Line 9 \\
\hline 8007 & 6065 & & 101 & Line 9 & & 101 & Line 9 & & 4 & Line 9 \\
\hline 10008 & 7047 & OSU DLT4A & 102 & Line 4 & OSU DLT4B & 102 & Line 4 & UW DAT48 & 1 & Line 4 \\
\hline 10009 & 7040 & & $103-104$ & Lines 4 and 9 & & $103-104$ & Lines 4 and 9 & & $2-3$ & Lines 4 and 9 \\
\hline 10011 & 7043 & & 105 & Line 9 & & 105 & Line 9 & & 4 & Line 9 \\
\hline 10013 & 7082 & & $106-107$ & Lines 4 and 9 & & 106-107 & Lines 4 and 9 & & $5-6$ & Lines 4 and 9 \\
\hline 10016 & 7093 & & 108 & Line 4 & & 108 & Line 4 & & 7 & Line 4 \\
\hline 10020 & 7088 & & 109 & Line 9 & & 109 & Line 9 & & 8 & Line 9 \\
\hline 10035 & 7053 & & 110 & Line 9 & & 110 & Line 9 & & 9 & Line 9 \\
\hline 10037 & 7101 & & 111 & Line 9 & & 111 & Line 9 & & 10 & Line 9 \\
\hline 10042 & 7113 & & 112 & Line 9 & & 112 & Line 9 & & 11 & Line 9 \\
\hline
\end{tabular}




\begin{tabular}{|c|c|c|c|c|c|c|c|c|c|c|}
\hline 10043 & 7109 & & 113 & Line 4 & & 113 & Line 4 & & 12 & Line 4 \\
\hline 10047 & 7103 & & 114-115 & Lines 4 and 9 & & $114-115$ & Lines 4 and 9 & & 13-14 & Lines 4 and 9 \\
\hline 10049 & 7086 & & 116 & Line 9 & & 116 & Line 9 & & 15 & Line 9 \\
\hline 10051 & 7087 & & 117 & Line 4 & & 117 & Line 4 & & 16 & Line 4 \\
\hline 10056 & 7060 & & 118 & Line 9 & & 118 & Line 9 & & 17 & Line 9 \\
\hline 10001 & 7041 & UW DLT1A & $1-11$ & Ch. 1 & UW DLT1B & $1-11$ & Ch. 1 & UW DAT1 & $1-11$ & Ch. 1 \\
\hline 10002 & 7114 & & $12-22$ & Ch. 1 & & $12-22$ & Ch. 1 & & $12-22$ & Ch. 1 \\
\hline 10003 & 7334 & & $23-33$ & Ch. 1 & & $23-33$ & Ch. 1 & & $23-33$ & Ch. 1 \\
\hline 10004 & 7627 & & $34-44$ & Ch. 3 & & $34-44$ & Ch. 3 & UW DAT2 & $1-11$ & Ch. 3 \\
\hline 10005 & 7074 & & $45-55$ & Ch. 1 & & $45-55$ & Ch. 1 & UW DAT3 & $1-11$ & Ch. 1 \\
\hline 10006 & 556 & & $56-66$ & All Zero files & & $56-66$ & All Zero files & & $12-22$ & All Zero files \\
\hline 10007 & 7364 & & $67-77$ & Ch. 1 & & $67-77$ & Ch. 1 & & $23-33$ & Ch. 1 \\
\hline 10008 & 7047 & & $78-88$ & $\begin{array}{l}\text { zerofiles 84-88, no lines } \\
7-11\end{array}$ & & $78-88$ & $\begin{array}{l}\text { zerofiles } 84-88, \text { no lines } \\
7-11\end{array}$ & & $34-44$ & $\begin{array}{l}\text { zerofiles } 40-44, \text { no lines } 7- \\
11\end{array}$ \\
\hline 10010 & 7629 & & $89-99$ & Ch. 3 & & $89-99$ & Ch. 3 & UW DAT4 & $1-11$ & Ch. 3 \\
\hline 10011 & 7043 & UW DLT2A & $1-11$ & Ch. 1 & UW DLT2B & $1-11$ & Ch. 1 & UW DAT5 & $1-11$ & Ch. 1 \\
\hline 10013 & 7082 & & $12-22$ & Ch. 1 & & $12-22$ & Ch. 1 & & $12-22$ & Ch. 1 \\
\hline 10014 & 7341 & & $23-33$ & Ch. 1 & & $23-33$ & Ch. 1 & & $23-33$ & Ch. 1 \\
\hline 10012 & 7591 & & $34-44$ & Ch. 3 & & $34-44$ & Ch. 3 & UW DAT6 & $1-11$ & Ch. 3 \\
\hline 10015 & 7091 & & $45-55$ & Ch. 1 & & $45-55$ & Ch. 1 & UW DAT7 & $1-11$ & Ch. 1 \\
\hline 10016 & 7093 & & $56-66$ & Ch. 1 & & 56-66 & Ch. 1 & & $12-22$ & Ch. 1 \\
\hline 10017 & 7068 & & $67-77$ & $\begin{array}{l}\text { zerofiles 74-76, no lines } \\
9-11\end{array}$ & & $67-77$ & $\begin{array}{l}\text { zerofiles } 75-77, \text { no lines } \\
9-11\end{array}$ & & $23-33$ & $\begin{array}{l}\text { zerofiles } 31-33 \text {, no lines 9- } \\
11\end{array}$ \\
\hline 10019 & 7050 & & $78-88$ & Ch. 1 & & 78-88 & Ch. 1 & & $34-44$ & Ch. 1 \\
\hline 10021 & 7094 & & $89-99$ & Ch. 1 & & $89-99$ & Ch. 1 & UW DAT8 & $1-11$ & Ch. 1 \\
\hline 10022 & 7096 & & $100-110$ & Ch. 1 & & $100-110$ & Ch. 1 & & $12-22$ & Ch. 1 \\
\hline 10020 & 7088 & UW DLT3A & $1-11$ & Ch. 1 & UW DLT3B & $1-11$ & Ch. 1 & UW DAT9 & $1-11$ & Ch. 1 \\
\hline 10021 & 7094 & & $12-12$ & Line 1 & & $12-12$ & Line 1 & & $12-12$ & Line 1 \\
\hline 10023 & 7438 & & $13-23$ & $\begin{array}{l}\text { zerofiles } 13-16 \text {, no lines } \\
1-4\end{array}$ & & $13-23$ & $\begin{array}{l}\text { zerofiles } 13-16 \text {, no lines } \\
1-4\end{array}$ & & $13-23$ & zerofiles $13-16$, no lines $1-4$ \\
\hline 10024 & 7279 & & $24-34$ & Ch. 1 & & $24-34$ & Ch. 1 & & $24-34$ & Ch. 1 \\
\hline 10025 & 7622 & & $35-45$ & Ch. 1 & & $35-45$ & Ch. 1 & UW DAT10 & $1-11$ & Ch. 1 \\
\hline 10026 & 7600 & & $46-56$ & Ch. 1 & & $46-56$ & Ch. 1 & & $12-22$ & Ch. 1 \\
\hline 10027 & 192 & & $57-67$ & Ch. 4 & & $57-67$ & Ch. 4 & & $23-33$ & Ch. 4 \\
\hline 10004 & 7627 & & $68-78$ & Ch. 1 & & $68-78$ & Ch. 1 & UW DAT11 & $1-11$ & Ch. 1 \\
\hline 10010 & 7629 & & $79-89$ & Ch. 1 & & 79-89 & Ch. 1 & & $12-22$ & Ch. 1 \\
\hline 10012 & 7591 & UW DLT4A & $1-11$ & Ch. 1 & UW DLT4B & $1-11$ & Ch. 1 & & $23-33$ & Ch. 1 \\
\hline 10018 & 391 & & $12-22$ & Ch. 4 & & $12-22$ & Ch. 1 & UW DAT12 & $1-11$ & Ch. 1 \\
\hline 10004 & 7627 & & $23-55$ & Ch. 2 and 3 & & $23-55$ & Ch. 2 and 3 & UW DAT40 & $1-22$ & Ch. 2 and 3 \\
\hline 10006 & 556 & & $56-77$ & $\begin{array}{l}\text { Ch. } 2 \text { and } 3 \text {, zerofiles } \\
56-61,66-77\end{array}$ & & $56-77$ & $\begin{array}{l}\text { Ch. } 2 \text { and } 3 \text {, zerofiles } \\
56-61,66-77\end{array}$ & UW DAT41 & $1-22$ & $\begin{array}{l}\text { Ch. } 2 \text { and } 3 \text {, zerofiles 1-6, } \\
11-22\end{array}$ \\
\hline 10010 & 7629 & & $78-99$ & Ch. 2 and 3 & & $78-99$ & Ch. 2 and 3 & & $23-44$ & Ch. 2 and 3 \\
\hline
\end{tabular}




\begin{tabular}{|c|c|c|c|c|c|c|c|c|c|c|}
\hline 10028 & 7611 & UW DLT5A & $1-11$ & Ch. 1 & UW DLT5B & $1-11$ & Ch. 1 & UW DAT13 & $1-11$ & Ch. 1 \\
\hline 10030 & 7095 & & $12-22$ & Ch. 1 & & $12-22$ & Ch. 1 & & $12-22$ & Ch. 1 \\
\hline 10031 & 878 & & $23-33$ & Ch. 4 & & $23-33$ & Ch. 4 & & $23-33$ & Ch. 1 \\
\hline 10032 & 7294 & & $34-44$ & Ch. 1 & & 34-44 & Ch. 1 & UW DAT14 & $1-11$ & Ch. 1 \\
\hline 10033 & 7071 & & $45-55$ & Ch. 1 & & $45-55$ & Ch. 1 & & $12-22$ & Ch. 1 \\
\hline 10034 & 7297 & & $56-66$ & Ch. 1 & & $56-66$ & Ch. 1 & & $23-33$ & Ch. 1 \\
\hline 10035 & 7053 & & $67-77$ & Ch. 1 & & $67-77$ & Ch. 1 & UW DAT15 & $1-11$ & Ch. 1 \\
\hline 10036 & 7350 & & 78-88 & Ch. 1 & & 78-88 & Ch. 1 & & $12-22$ & Ch. 1 \\
\hline 10037 & 7101 & & $89-99$ & Ch. 1 & & 89-99 & Ch. 1 & & $23-33$ & Ch. 1 \\
\hline 10038 & 7108 & & $100-110$ & Ch. 1 & & $100-110$ & Ch. 1 & UW DAT 16 & $1-11$ & Ch. 1 \\
\hline 10039 & 7601 & & 111-121 & Ch. 1 & & $111-121$ & Ch. 1 & & $12-22$ & Ch. 1 \\
\hline 10040 & 7619 & & 122-132 & Ch. 1 & & $122-132$ & Ch. 1 & & $23-33$ & Ch. 1 \\
\hline 10042 & 7113 & & 133-143 & Ch. 1 & & 133-143 & Ch. 1 & UW DAT17 & $1-11$ & Ch. 1 \\
\hline 10043 & 7109 & & 144-154 & Ch. 1 & & 144-154 & Ch. 1 & & $12-22$ & Ch. 1 \\
\hline 10044 & 7054 & & $155-165$ & Ch. 1 & & $155-165$ & Ch. 1 & & $23-33$ & Ch. 1 \\
\hline 10045 & 7467 & UW DLT6A & $1-11$ & Ch. 1 & UW DLT6B & $1-11$ & Ch. 1 & UW DAT18 & $1-11$ & Ch. 1 \\
\hline 10046 & 7076 & & $12-22$ & Ch. 1 & & $12-22$ & Ch. 1 & UW DAT19 & $1-11$ & Ch. 1 \\
\hline 10047 & 7103 & & $23-33$ & Ch. 1 & & $23-33$ & Ch. 1 & UW DAT20 & $1-11$ & Ch. 1 \\
\hline 10048 & 7342 & & $34-44$ & Ch. 1 & & $34-44$ & Ch. 1 & UW DAT21 & $1-11$ & Ch. 1 \\
\hline 10049 & 7086 & & 45-55 & Ch. 1 & & 45-55 & Ch. 1 & & $12-22$ & Ch. 1 \\
\hline 10050 & 7346 & & $56-66$ & Ch. 1 & & $56-66$ & Ch. 1 & UW DAT22 & $1-11$ & Ch. 1 \\
\hline 10051 & 7087 & & $67-77$ & Ch. 1 & & $67-77$ & Ch. 1 & UW DAT23 & $1-11$ & Ch. 1 \\
\hline 10052 & 7084 & & 78-88 & Ch. 1 & & 78-88 & Ch. 1 & UW DAT24 & $1-11$ & Ch. 1 \\
\hline 10053 & 384 & & $89-99$ & Ch. 4 & & 89-99 & Ch. 4 & UW DAT25 & $1-11$ & Ch. 1 \\
\hline 10054 & 7065 & & $100-110$ & Ch. 1 & & 100-110 & Ch. 1 & UW DAT26 & $1-11$ & Ch. 1 \\
\hline 10055 & 7328 & & 111-121 & Ch. 1 & & 111-121 & Ch. 1 & & $12-22$ & Ch. 1 \\
\hline 10056 & 7060 & & $122-132$ & Ch. 1 & & $122-132$ & Ch. 1 & & $23-33$ & Ch. 1 \\
\hline 10057 & 875 & & 133-143 & Ch. 4 & & $133-143$ & Ch. 4 & UW DAT27 & $1-11$ & Ch. 1 \\
\hline 10058 & 7090 & & 144-154 & Ch. 1 & & 144-154 & Ch. 1 & UW DAT28 & $1-11$ & Ch. 1 \\
\hline 10059 & 553 & & 155-165 & Ch. 4 & & $155-165$ & Ch. 4 & UW DAT29 & $1-11$ & Ch. 1 \\
\hline 10060 & 7609 & UW DLT7A & $1-33$ & Ch. 1-3 & UW DLT7B & $1-33$ & Ch. 1-3 & UW DAT30 & $1-33$ & Ch. 1-3 \\
\hline 10028 & 7611 & & $34-55$ & Ch. 2 and 3 & & $34-55$ & Ch. 2 and 3 & UW DAT31 & $1-22$ & Ch. 2 and 3 \\
\hline 10031 & 878 & & 56-77 & Ch. 5 and 6 & & 56-77 & Ch. 5 and 6 & UW DAT32 & $1-22$ & Ch. 5 and 6 \\
\hline 10032 & 7294 & UW DLT8A & $1-22$ & Ch. 2 and 3 & UW DLT8B & $1-22$ & Ch. 2 and 3 & UW DAT33 & $1-22$ & Ch. 2 and 3 \\
\hline 10034 & 7297 & & 23-44 & Ch. 2 and 3 & & 23-44 & Ch. 2 and 3 & UW DAT34 & $1-22$ & Ch. 2 and 3 \\
\hline 10039 & 7601 & & $45-66$ & Ch. 2 and 3 & & $45-66$ & Ch. 2 and 3 & UW DAT35 & $1-22$ & Ch. 2 and 3 \\
\hline 10040 & 7619 & & $67-88$ & Ch. 2 and 3 & & $67-88$ & Ch. 2 and 3 & UW DAT36 & $1-22$ & Ch. 2 and 3 \\
\hline 10053 & 384 & UW DLT9A & $1-22$ & Ch. 5 and 6 & UW DLT9B & $1-22$ & Ch. 5 and 6 & UW DAT37 & $1-22$ & Ch. 5 and 6 \\
\hline 10057 & 875 & & $23-44$ & Ch. 5 and 6 & & $23-44$ & Ch. 5 and 6 & UW DAT38 & $1-22$ & Ch. 5 and 6 \\
\hline 10059 & 553 & & $45-66$ & Ch. 5 and 6 & & $45-66$ & Ch. 5 and 6 & UW DAT39 & $1-22$ & Ch. 5 and 6 \\
\hline 10012 & 7591 & UW DLT10A & $1-22$ & Ch. 2 and 3 & UW DLT10B & $1-22$ & Ch. 2 and 3 & UW DAT42 & $1-22$ & Ch. 2 and 3 \\
\hline 10018 & 391 & & $23-44$ & Ch. 5 and 6 & & $23-44$ & Ch. 5 and 6 & UW DAT43 & $1-22$ & Ch. 5 and 6 \\
\hline
\end{tabular}




\begin{tabular}{|c|c|c|c|c|c|c|c|c|c|c|}
\hline 10023 & 7438 & & $45-66$ & $\begin{array}{l}\text { Ch. } 2 \text { and } 3 \text {, Zerofiles } \\
45-52, \text { no lines 1-4 }\end{array}$ & & $45-66$ & $\begin{array}{l}\text { Ch. } 2 \text { and } 3, \text { Zerofiles } \\
45-52 \text {, no lines 1-4 }\end{array}$ & UW DAT44 & $1-22$ & $\begin{array}{l}\text { Ch. } 2 \text { and } 3 \text {, Zerofiles 1-8, } \\
\text { no lines 1-4 }\end{array}$ \\
\hline 10024 & 7279 & & $67-88$ & Ch. 2 and 3 & & $67-88$ & Ch. 2 and 3 & UW DAT45 & $1-22$ & Ch. 2 and 3 \\
\hline 10026 & 7600 & & $89-110$ & Ch. 2 and 3 & & $89-110$ & Ch. 2 and 3 & UW DAT46 & $1-22$ & Ch. 2 and 3 \\
\hline 10027 & 192 & & $111-132$ & Ch. 5 and 6 & & $111-132$ & Ch. 5 and 6 & UW DAT47 & $1-22$ & Ch. 5 and 6 \\
\hline 10008 & 7047 & OSU DLT4A & 102 & Line 4 & OSU DLT4B & 102 & Line 4 & UW DAT48 & 1 & Line 4 \\
\hline 10009 & 7040 & & 103-104 & Lines 4 and 9 & & $103-104$ & Lines 4 and 9 & & $2-3$ & Lines 4 and 9 \\
\hline 10011 & 7043 & & 105 & Line 9 & & 105 & Line 9 & & 4 & Line 9 \\
\hline 10013 & 7082 & & 106-107 & Lines 4 and 9 & & $106-107$ & Lines 4 and 9 & & $5-6$ & Lines 4 and 9 \\
\hline 10016 & 7093 & & 108 & Line 4 & & 108 & Line 4 & & 7 & Line 4 \\
\hline 10020 & 7088 & & 109 & Line 9 & & 109 & Line 9 & & 8 & Line 9 \\
\hline 10035 & 7053 & & 110 & Line 9 & & 110 & Line 9 & & 9 & Line 9 \\
\hline 10037 & 7101 & & 111 & Line 9 & & 111 & Line 9 & & 10 & Line 9 \\
\hline 10042 & 7113 & & 112 & Line 9 & & 112 & Line 9 & & 11 & Line 9 \\
\hline 10043 & 7109 & & 113 & Line 4 & & 113 & Line 4 & & 12 & Line 4 \\
\hline 10047 & 7103 & & 114-115 & Lines 4 and 9 & & $114-115$ & Lines 4 and 9 & & $13-14$ & Lines 4 and 9 \\
\hline 10049 & 7086 & & 116 & Line 9 & & 116 & Line 9 & & 15 & Line 9 \\
\hline 10051 & 7087 & & 117 & Line 4 & & 117 & Line 4 & & 16 & Line 4 \\
\hline 10056 & 7060 & & 118 & Line 9 & & 118 & Line 9 & & 17 & Line 9 \\
\hline 9030 & 7075 & OSU DLT3A & $1-11$ & $\begin{array}{l}\text { zero files } 7-11, \text { no lines } \\
7-11\end{array}$ & OSU DLT3B & $1-11$ & $\begin{array}{l}\text { zero files } 7-11, \text { no lines } \\
7-11\end{array}$ & OSU DAT27 & $1-11$ & zero files $7-11$, no lines $7-11$ \\
\hline 11001 & 7337 & & $12-24$ & $\begin{array}{l}\text { CA23, CA01,CA26 - } \\
\text { Ch. } 1\end{array}$ & & $12-24$ & $\begin{array}{l}\text { CA23, CA01,CA26 - } \\
\text { Ch. } 1\end{array}$ & CAN DAT1 & $1-13$ & CA23, CA01,CA26 - Ch. 1 \\
\hline 11008 & 7287 & & $25-35$ & Ch. 1 & & $25-35$ & Ch. 1 & & $14-24$ & Ch. 1 \\
\hline 11009 & 7606 & & $36-46$ & Ch. 1 & & $36-46$ & Ch. 1 & & $25-35$ & Ch. 1 \\
\hline 11014 & 7344 & & $47-57$ & Ch. 1 & & $47-57$ & Ch. 1 & CAN DAT2 & $1-11$ & Ch. 1 \\
\hline 11016 & 7343 & & $58-68$ & Ch. 1 & & $58-68$ & Ch. 1 & & $12-22$ & Ch. 1 \\
\hline 11017 & 7599 & & $69-79$ & Ch. 1 & & $69-79$ & Ch. 1 & & $23-33$ & Ch. 1 \\
\hline 11018 & 7280 & & $80-90$ & Ch. 1 & & $80-90$ & Ch. 1 & CAN DAT3 & $1-11$ & Ch. 1 \\
\hline 11019 & 7625 & & 91-101 & Ch. 1 & & $91-101$ & Ch. 1 & & $12-22$ & Ch. 1 \\
\hline 11020 & 7299 & & $102-112$ & Ch. 1 & & $102-112$ & Ch. 1 & & $23-33$ & Ch. 1 \\
\hline 11034 & 7332 & & $113-123$ & CA34, CA39 - Ch. 1 & & $113-123$ & CA34, CA39 - Ch. 1 & CAN DAT4 & $1-11$ & CA34, CA39 - Ch. 1 \\
\hline 11035 & 7429 & & $124-134$ & CA35, CA38 - Ch. 1 & & $124-134$ & CA35, CA38 - Ch. 1 & & $12-22$ & CA35, CA38 - Ch. 1 \\
\hline 11036 & 7351 & & $135-145$ & $\begin{array}{l}\text { CA36, CA42 - All Zero } \\
\text { files }\end{array}$ & zero files & $135-145$ & $\begin{array}{l}\text { CA36, CA42 - All Zero } \\
\text { files }\end{array}$ & zero files & $23-33$ & CA36, CA42 - All Zero files \\
\hline 11037 & 7281 & & $146-156$ & CA37, CA41 - Ch. 1 & & $146-156$ & CA37, CA41 - Ch. 1 & & $34-44$ & CA37, CA41 - Ch. 1 \\
\hline 11044 & 7445 & & $157-167$ & Ch. 1 & & $157-167$ & Ch. 1 & CAN DAT5 & $1-11$ & Ch. 1 \\
\hline 11045 & 7360 & & $168-178$ & Ch. 1 & & $168-178$ & Ch. 1 & & $12-22$ & Ch. 1 \\
\hline 11046 & 7348 & CAN DLT1A & $1-11$ & Ch. 1 & CAN DLT1B & $1-11$ & Ch. 1 & & $23-33$ & Ch. 1 \\
\hline 11047 & 7446 & & $12-22$ & Ch. 1 & & $12-22$ & Ch. 1 & CAN DAT6 & $1-11$ & Ch. 1 \\
\hline 11048 & 7430 & & $23-33$ & Ch. 1 & & 23-33 & Ch. 1 & & $12-22$ & Ch. 1 \\
\hline 11049 & 7449 & & $34-44$ & Ch. 1 & & $34-44$ & Ch. 1 & & $23-33$ & Ch. 1 \\
\hline
\end{tabular}




\begin{tabular}{|c|c|c|c|c|c|c|c|c|c|c|}
\hline 11050 & 7333 & & $45-55$ & Ch. 1 & & $45-55$ & Ch. 1 & CAN DAT7 & $1-11$ & Ch. 1 \\
\hline 11051 & 7322 & & $56-66$ & Ch. 1 & & $56-66$ & Ch. 1 & & $12-22$ & Ch. 1 \\
\hline 11052 & 7433 & & $67-77$ & Ch. 1 & & $67-77$ & Ch. 1 & & $23-33$ & Ch. 1 \\
\hline 11053 & 7612 & & $78-88$ & Ch. 1 & & $78-88$ & Ch. 1 & CAN DAT8 & $1-11$ & Ch. 1 \\
\hline Tully & 7356 & & $89-99$ & $\begin{array}{l}\text { zero files } 89-93, \text { no } \\
\text { lines 1-5 }\end{array}$ & & $89-99$ & $\begin{array}{l}\text { zero files } 89-93 \text {, no lines } \\
1-5\end{array}$ & & $12-22$ & zero files $12-16$, no lines $1-5$ \\
\hline 11002 & 6116 & & $100-112$ & $\begin{array}{l}\text { CA27, CA02, CA29 - } \\
\text { Ch. } 1\end{array}$ & & $100-112$ & $\begin{array}{l}\text { CA27, CA02, CA29 - } \\
\text { Ch. } 1\end{array}$ & CAN DAT9 & $1-13$ & CA27, CA02, CA29-Ch. 1 \\
\hline 11003 & 6126 & & $113-124$ & CA25, CA03 - Ch. 1 & & $113-124$ & CA25, CA03 - Ch. 1 & & $14-25$ & CA25, CA03 - Ch. 1 \\
\hline 11004 & 6110 & & $125-135$ & Ch. 1 & & $125-135$ & Ch. 1 & CAN DAT10 & $1-11$ & Ch. 1 \\
\hline 11005 & 6119 & & $136-146$ & Ch. 1 & & $136-146$ & Ch. 1 & & $12-22$ & Ch. 1 \\
\hline 11006 & 6039 & & $147-157$ & Ch. 1 & & $147-157$ & Ch. 1 & & $23-33$ & Ch. 1 \\
\hline 11007 & 7301 & & $158-169$ & $\begin{array}{l}\text { CA07, CA07A, zerofile } \\
158, \text { no line } 1\end{array}$ & & $158-169$ & $\begin{array}{l}\text { CA07, CA07A, zerofile } \\
158, \text { no line } 1\end{array}$ & & $34-45$ & $\begin{array}{l}\text { CA07, CA07A, zerofile } 34, \\
\text { no line } 1\end{array}$ \\
\hline 11010 & 6113 & & $170-182$ & $\begin{array}{l}\text { CA26, CA10, CA25 - } \\
\text { Ch. } 1\end{array}$ & & $170-182$ & $\begin{array}{l}\text { CA26, CA10, CA25 - } \\
\text { Ch. } 1\end{array}$ & & $46-58$ & CA26,CA10,CA25 - Ch. 1 \\
\hline 11012 & 6111 & & $183-193$ & Ch. 1 & & $183-193$ & Ch. 1 & CAN DAT11 & $1-11$ & Ch. 1 \\
\hline 11013 & 6060 & & $194-206$ & $\begin{array}{l}\text { CA29, CA13, CA27 - } \\
\text { Ch. } 1\end{array}$ & & $194-206$ & $\begin{array}{l}\text { CA29, CA13, CA27 - } \\
\text { Ch. } 1\end{array}$ & & $12-24$ & CA29, CA13, CA27 - Ch. 1 \\
\hline 11015 & 6109 & & $207-217$ & Ch. 1 & & $207-217$ & Ch. 1 & & $25-35$ & Ch. 1 \\
\hline 11011 & 6058 & & $218-230$ & $\begin{array}{l}\text { CA28, CA11, CA28 - } \\
\text { Ch. } 1\end{array}$ & & $218-230$ & $\begin{array}{l}\text { CA28, CA11, CA28 - } \\
\text { Ch. } 1\end{array}$ & & $36-48$ & CA28, CA11, CA28 - Ch. 1 \\
\hline 11036 & 7351 & CAN DLT2A & $1-11$ & CA36, CA42 - Ch. 1 & CAN DLT2B & $1-11$ & CA36, CA42 - Ch. 1 & CAN DAT12 & $1-11$ & CA36, CA42 - Ch. 1 \\
\hline 11021 & 7610 & copy of & $12-22$ & Ch. 1 & & $12-22$ & Ch. 1 & CAN DAT13 & $1-11$ & Ch. 1 \\
\hline 11022 & 7331 & CAN DLT2B & $23-33$ & Ch. 1 & & $23-33$ & Ch. 1 & & $12-22$ & Ch. 1 \\
\hline 11024 & 7456 & & $34-44$ & Ch. 1 & & $34-44$ & Ch. 1 & & $23-33$ & Ch. 1 \\
\hline 11030 & 7277 & & $45-55$ & Ch. 1 & & $45-55$ & Ch. 1 & CAN DAT14 & $1-11$ & Ch. 1 \\
\hline 11031 & 7623 & & $56-66$ & Ch. 1 & & $56-66$ & Ch. 1 & & $12-22$ & Ch. 1 \\
\hline 11032 & 7284 & & $67-77$ & Ch. 1 & & $67-77$ & Ch. 1 & & $23-33$ & Ch. 1 \\
\hline 11033 & 7628 & & $78-88$ & Ch. 1 & & $78-88$ & Ch. 1 & CAN DAT15 & $1-11$ & Ch. 1 \\
\hline 11043 & 7431 & & $89-99$ & Ch. 1 & & $89-99$ & Ch. 1 & & $12-22$ & Ch. 1 \\
\hline 11021 & 7610 & CAN DLT3A & $1-22$ & Ch. 2 and 3 & CAN DLT3A & $1-22$ & Ch. 2 and 3 & CAN DAT16 & $1-22$ & Ch. 2 and 3 \\
\hline 11030 & 7277 & & $23-44$ & Ch. 2 and 3 & & $23-44$ & Ch. 2 and 3 & CAN DAT17 & $1-22$ & Ch. 2 and 3 \\
\hline 11031 & 7623 & & $45-66$ & Ch. 2 and 3 & & $45-66$ & Ch. 2 and 3 & CAN DAT18 & $1-22$ & Ch. 2 and 3 \\
\hline 11032 & 7284 & & $67-88$ & Ch. 2 and 3 & & $67-88$ & Ch. 2 and 3 & CAN DAT19 & $1-22$ & Ch. 2 and 3 \\
\hline 11033 & 7628 & & $89-110$ & Ch. 2 and 3 & & $89-110$ & Ch. 2 and 3 & CAN DAT20 & $1-22$ & Ch. 2 and 3 \\
\hline \multirow[t]{2}{*}{11007} & 7301 & & $111-134$ & Ch. 2 and 3 & & $111-134$ & Ch. 2 and 3 & CAN DAT21 & $1-22$ & Ch. 2 and 3 \\
\hline & & & & $\begin{array}{l}\text { zerofiles 111-112, no } \\
\text { line } 1\end{array}$ & & & $\begin{array}{l}\text { zerofiles 111-112, no } \\
\text { line } 1\end{array}$ & & & zerofiles $1-2$, no line 1 \\
\hline 11017 & 7599 & & $135-156$ & Ch. 2 and 3 & & $135-156$ & Ch. 2 and 3 & CAN DAT22 & $1-22$ & Ch. 2 and 3 \\
\hline 11018 & 7280 & & $157-178$ & Ch. 2 and 3 & & $157-178$ & Ch. 2 and 3 & CAN DAT23 & $1-22$ & Ch. 2 and 3 \\
\hline 11019 & 7625 & CAN DLT4A & $1-22$ & Ch. 2 and 3 & CAN DLT4B & $1-22$ & Ch. 2 and 3 & CAN DAT24 & $1-22$ & Ch. 2 and 3 \\
\hline
\end{tabular}




\begin{tabular}{|c|c|c|c|c|c|c|c|c|}
\hline 11020 & 7299 & $23-44$ & Ch. 2 and 3 & $23-44$ & Ch. 2 and 3 & CAN DAT25 & $1-22$ & Ch. 2 and 3 \\
\hline 11008 & 7287 & $45-66$ & Ch. 2 and 3 & $45-66$ & Ch. 2 and 3 & CAN DAT26 & $1-22$ & Ch. 2 and 3 \\
\hline 11009 & 7606 & $67-88$ & Ch. 2 and 3 & $67-88$ & Ch. 2 and 3 & CAN DAT27 & $1-22$ & Ch. 2 and 3 \\
\hline 11007 & 7301 & & & & & CAN DAT28 & $1-30$ & Ch. 1-3, Lines 2-11 \\
\hline 9006 & 7598 & $89-110$ & Ch. 2 and 3 & $89-110$ & Ch. 2 and 3 & OSU DAT28 & $1-22$ & Ch. 2 and 3 \\
\hline 9018 & 7302 & $111-132$ & Ch. 2 and 3 & $111-132$ & Ch. 2 and 3 & OSU DAT29 & $1-22$ & Ch. 2 and 3 \\
\hline 9023 & 338 & 133-154 & Ch. 5 and 6 & 133-154 & Ch. 5 and 6 & OSU DAT30 & $1-22$ & Ch. 5 and 6 \\
\hline 9008 & 7072 & $155-187$ & $\begin{array}{l}\text { Zerofiles 156-157, 159- } \\
160,162-163,165-166, \\
168-169 \text { Ch. } 1-3\end{array}$ & $155-187$ & $\begin{array}{l}\text { Zerofiles 156-157, 159- } \\
160,162-163,165-166, \\
168-169, \text { Ch. } 1-3\end{array}$ & OSU DAT31 & $1-33$ & Ch. 1-3 \\
\hline
\end{tabular}

copy_segy_tape (need number of the first file to copy, the number of the last file to copy, and path names of the tape drive of tape to be copied (in_device) and of the tape drive to copy the tape onto (out_device)

\section{\#! /bin/sh}

\# Program to do a tape to tape copy with segy files

\# assumes the existence of an mt asf command

\# assumes tcopy returns 0 on successfull completion

\# non-zero on failure

\section{if test \$\# -1t 4}

then

echo "Need 4 args; start, stop, in_device, out_device"

exit

\section{STARTNUM $=\$ 1$}

ENDNUM $=\$ 2$

INTAPE $=\$ 3$

OUTTAPE $=\$ 4$

mt -f \$INTAPE asf 'expr \$STARTNUM - 1`

mt -f \$OUTTAPE asf `expr \$STARTNUM - 1

\section{CURRNUM=\$STARTNUM}

while test \$CURRNUM -le \$ENDNUM

do 
echo "Copying record \$CURRNUM"

RETURNVAL=`tcopy \$INTAPE \$OUTTAPE | grep "record 2" if test -n "\$RETURNVAL"

then

echo "Successful Record \$CURRNUM"

else

echo "Un-successful \$CURRNUM; rewinding tapes" mt -f \$INTAPE asf \$CURRNUM

$m t$-f \$OUTTAPE asf \$CURRNUM

fi

CURRNUM=`expr \$CURRNUM + 1

done 


\begin{tabular}{|c|c|}
\hline & APPENDIX 6. PASSCAL SEGY Trace Header Format \\
\hline Byte \# & Description \\
\hline $1-4$ & Trace sequence number within data stream \\
\hline $5-8$ & Trace sequence number within reel (same as above) \\
\hline $9-12$ & Event number \\
\hline $13-16$ & $\begin{array}{l}\text { Channel number }=1 \text { or } 4 \text { for the vertical component, } 2 \text { or } 5 \text { for the N-S horizontal } \\
\text { component, } 3 \text { or } 6 \text { for the E-W horizontal component }\end{array}$ \\
\hline $29-30$ & Trace identification code $=1$ for seismic data \\
\hline $69-70$ & Elevation constant $=1$ \\
\hline $71-72$ & Coordinate constant $=1$ \\
\hline $89-90$ & Coordinate units $=2$ for Lat/Long \\
\hline $103-104$ & Low 2 bytes of the total shift in milliseconds \\
\hline $115-116$ & $\begin{array}{l}\text { Number of samples in this trace } \\
\quad \text { (note if equal } 32767 \text { see bytes } 229-232 \text { ) }\end{array}$ \\
\hline $117-118$ & $\begin{array}{l}\text { Sample interval in microsecs for this trace } \\
\text { (note if equal } 1 \text { see bytes } 201-204 \text { ) }\end{array}$ \\
\hline $119-120$ & Fixed gain flag $=1$ \\
\hline $121-122$ & Gain of amplifier \\
\hline $157-158$ & Year data recorded \\
\hline $159-160$ & Day of year \\
\hline $161-162$ & Hour of day ( 24 hour clock) \\
\hline $163-164$ & Minute of hour \\
\hline $165-166$ & Second of minute \\
\hline $\begin{array}{l}167-168 \\
\mid\end{array}$ & Time basis code: $1=$ local $2=$ GMT $3=$ other \\
\hline $174-174$ & Stake number index \\
\hline $181-186^{*}$ & Station Name code ( 5 chars +1 for termination $)$ \\
\hline $187-194 *$ & Sensor Serial code ( 7 chars +1 for termination) \\
\hline $195-198 *$ & Channel Name code ( 3 chars +1 for termination) \\
\hline $199-200^{*}$ & Extra bytes ( 2 chars) \\
\hline $201-204 *$ & Sample interval in microsecs as a 32 bit integer \\
\hline $205-206^{*}$ & Data format flag: $0=16$ bit integer $1=32$ bit integer \\
\hline $207-208^{*}$ & Milliseconds of second for first sample \\
\hline $209-210 *$ & Trigger time year \\
\hline
\end{tabular}




\begin{tabular}{|ll|}
\hline $211-212^{*}$ & Trigger time Julian day \\
$213-214^{*}$ & Trigger time hour \\
$215-216^{*}$ & Trigger time minutes \\
$217-218^{*}$ & Trigger time seconds \\
$219-220^{*}$ & Trigger time milliseconds \\
$221-224^{*}$ & $\quad$ Scale factor (IEEE 32 bit float) \\
& $\quad$ (true amplitude = (data value)*(scale factor)/gain \\
$225-226^{*}$ & Instrument Serial Number \\
$229-232^{*}$ & Number of Samples as a 32 bit integer \\
$233-236^{*}$ & Max value in counts. \\
$237-240^{*}$ & Min value in counts. \\
\hline
\end{tabular}

*Header values not specified in the standard SEGY format 


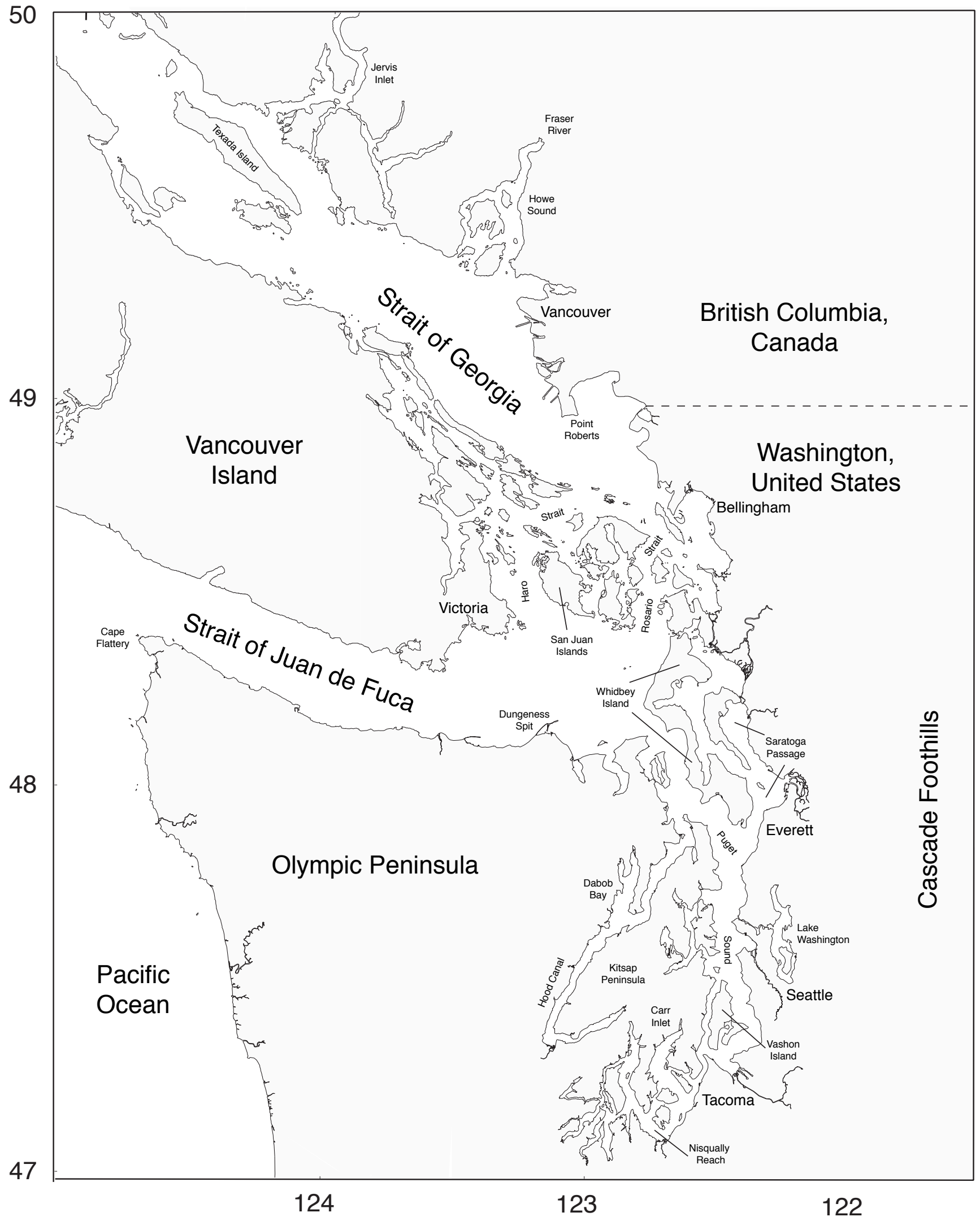

Figure 1. Map of study area showing major sedimentary basins and cities 


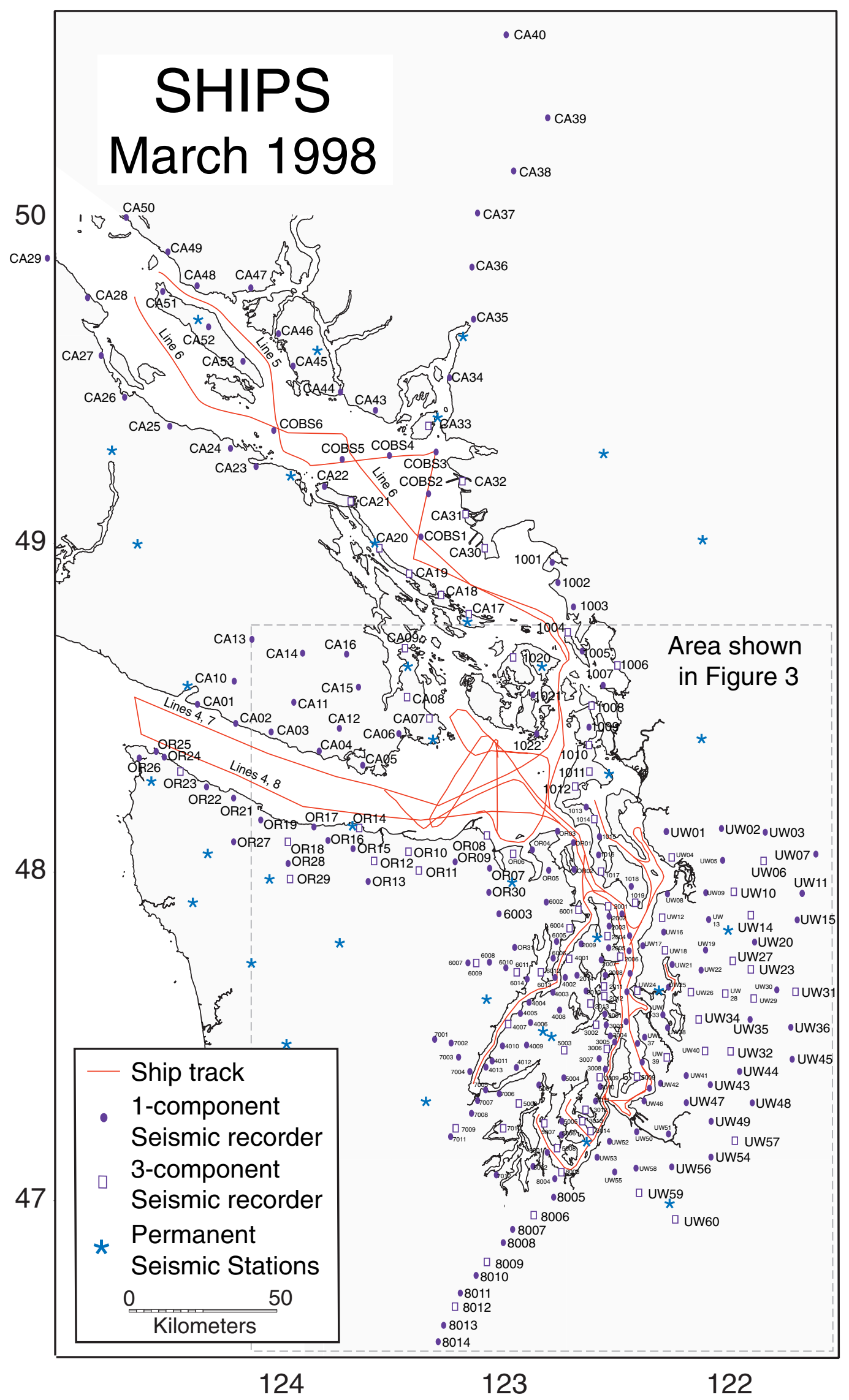

Figure 2. Map of study area showing locations of SHIPS seismic lines and recorders. 


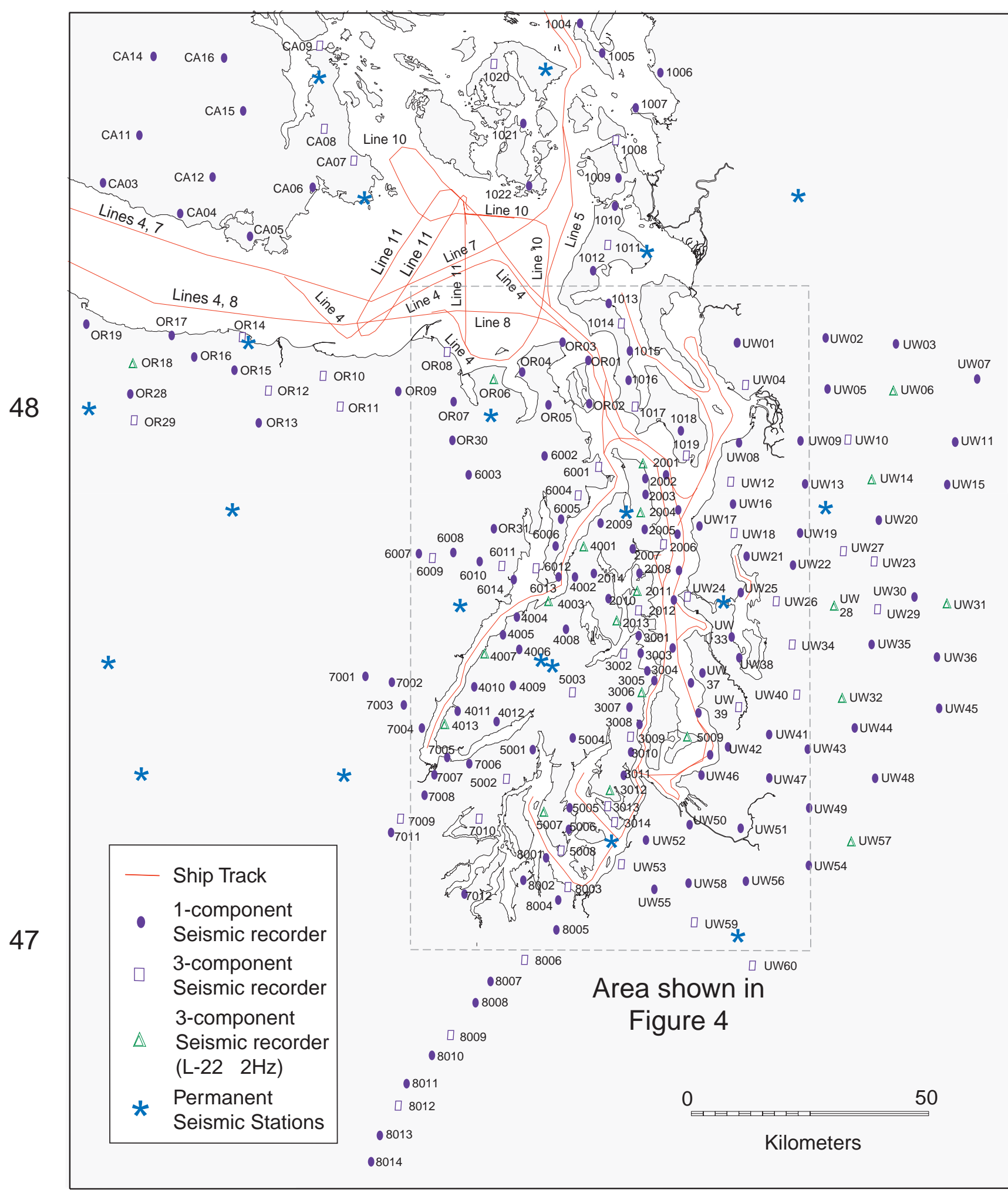

124

Figure 3. Detail of map showing locations of SHIPS seismic lines and recorders. 


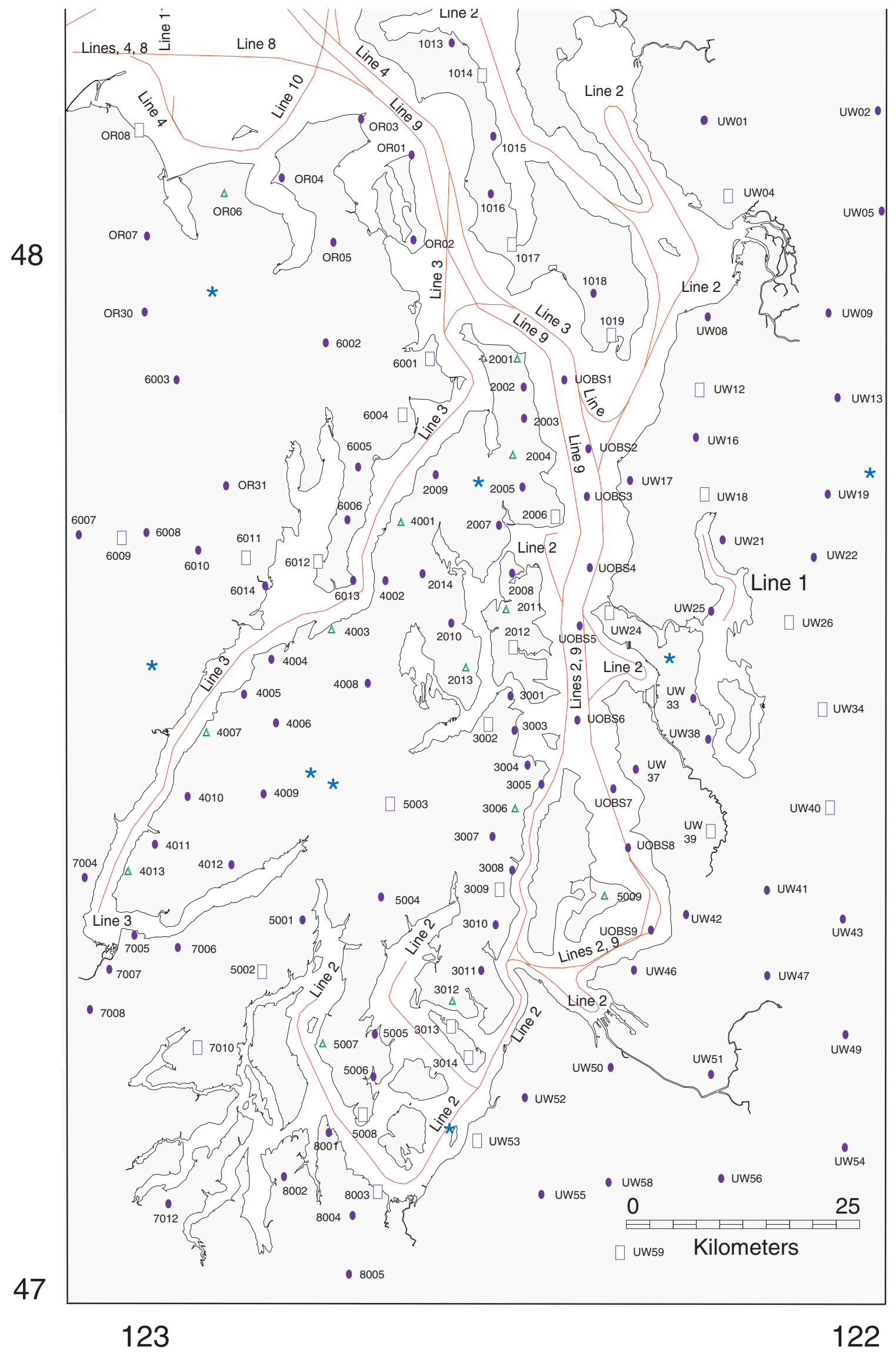

Figure 4. Map showing locations of SHIP seismic lines and recorders in the Puget Lowland. 


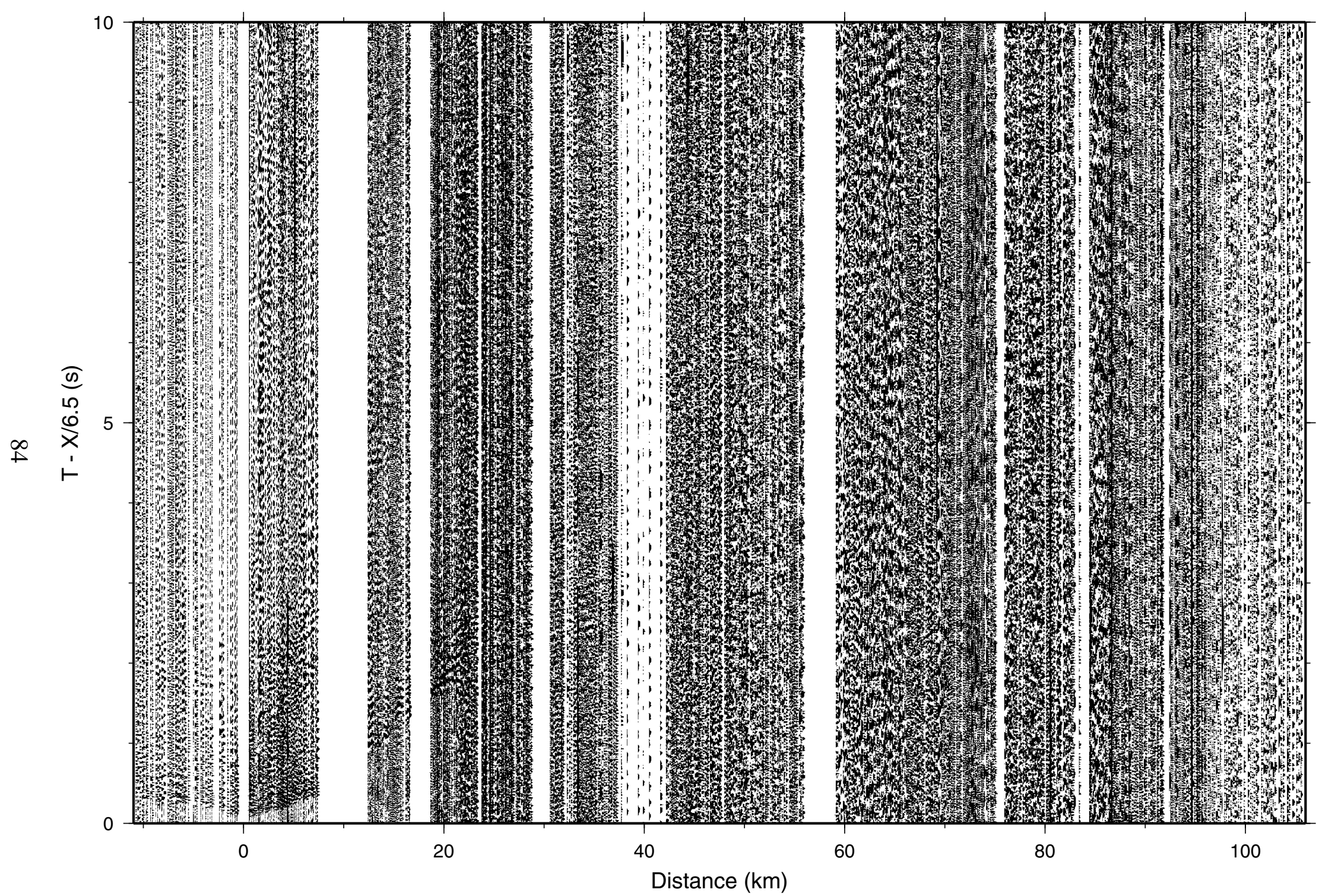

Figure 5. Reduced record section for Shotpoint 4, vertical component only, for Lines 1 and 2. 

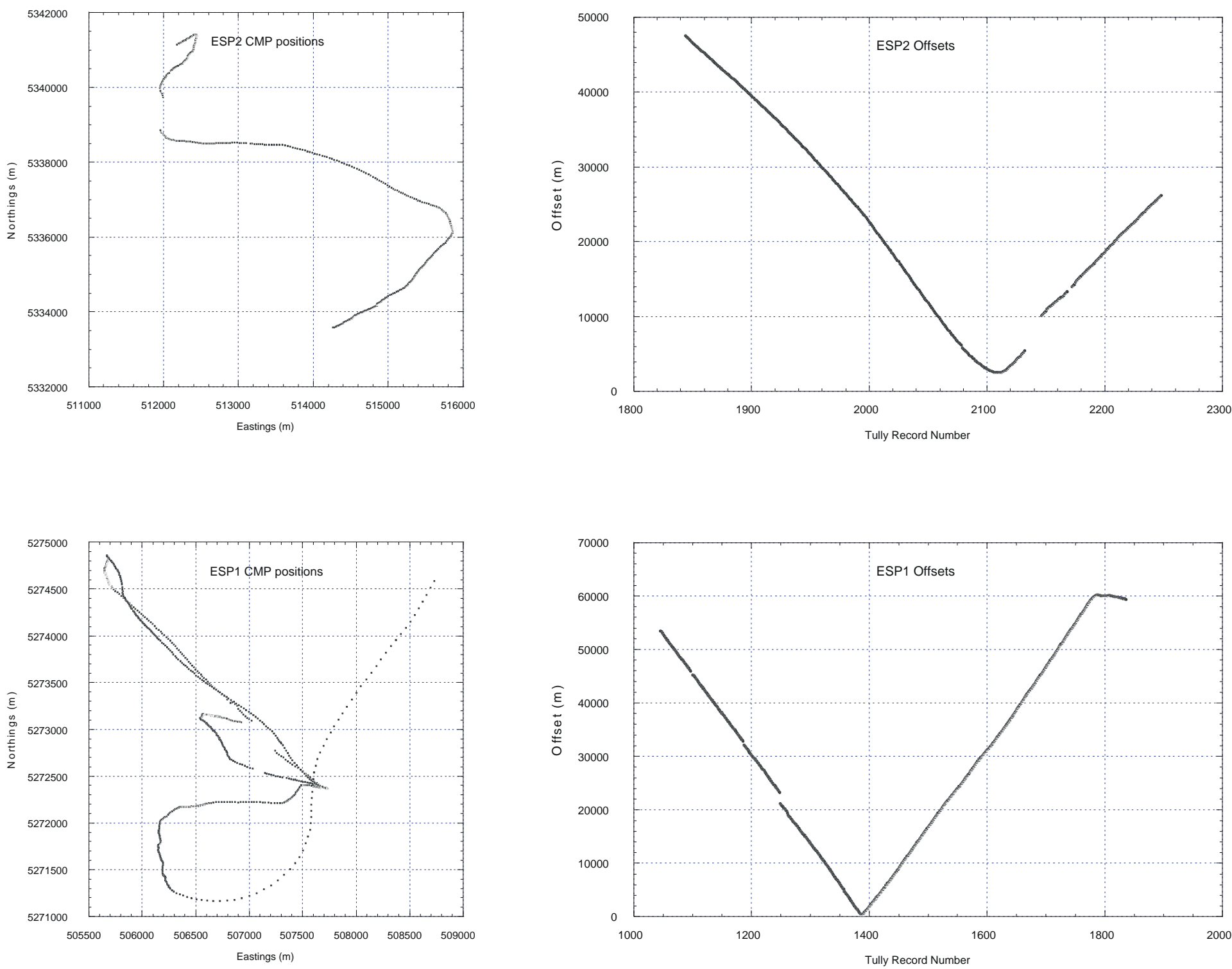

Figure 6. Maps showing distribution of common midpoints (left) and receiver offsets as a function of R/V Tully record number (right) for ESPs 2 and 1. 

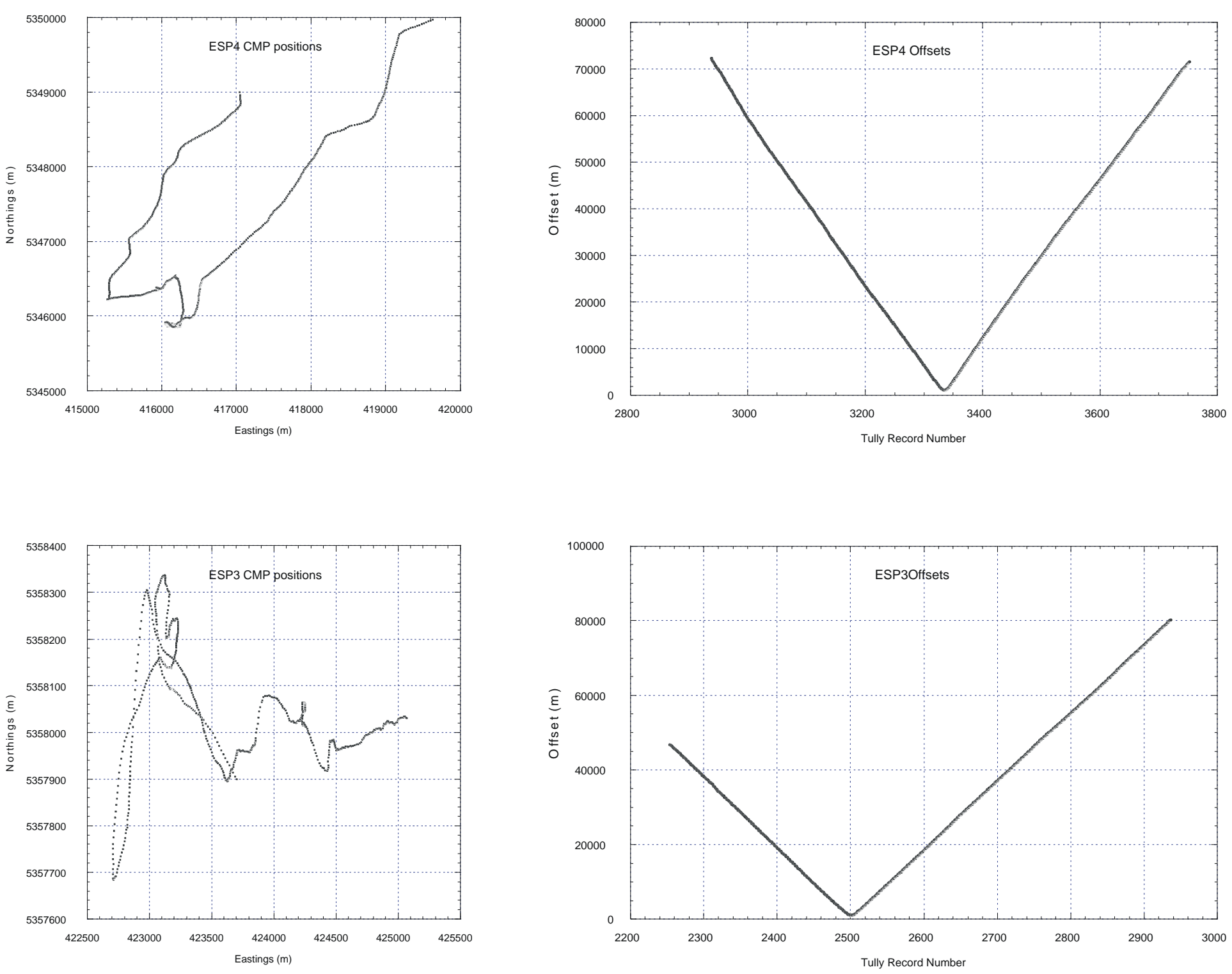

Figure 7. Maps showing distribution of common midpoints (left) and receiver offsets as a function of R/V Tully record number (right) for ESPs 4 and 3. 

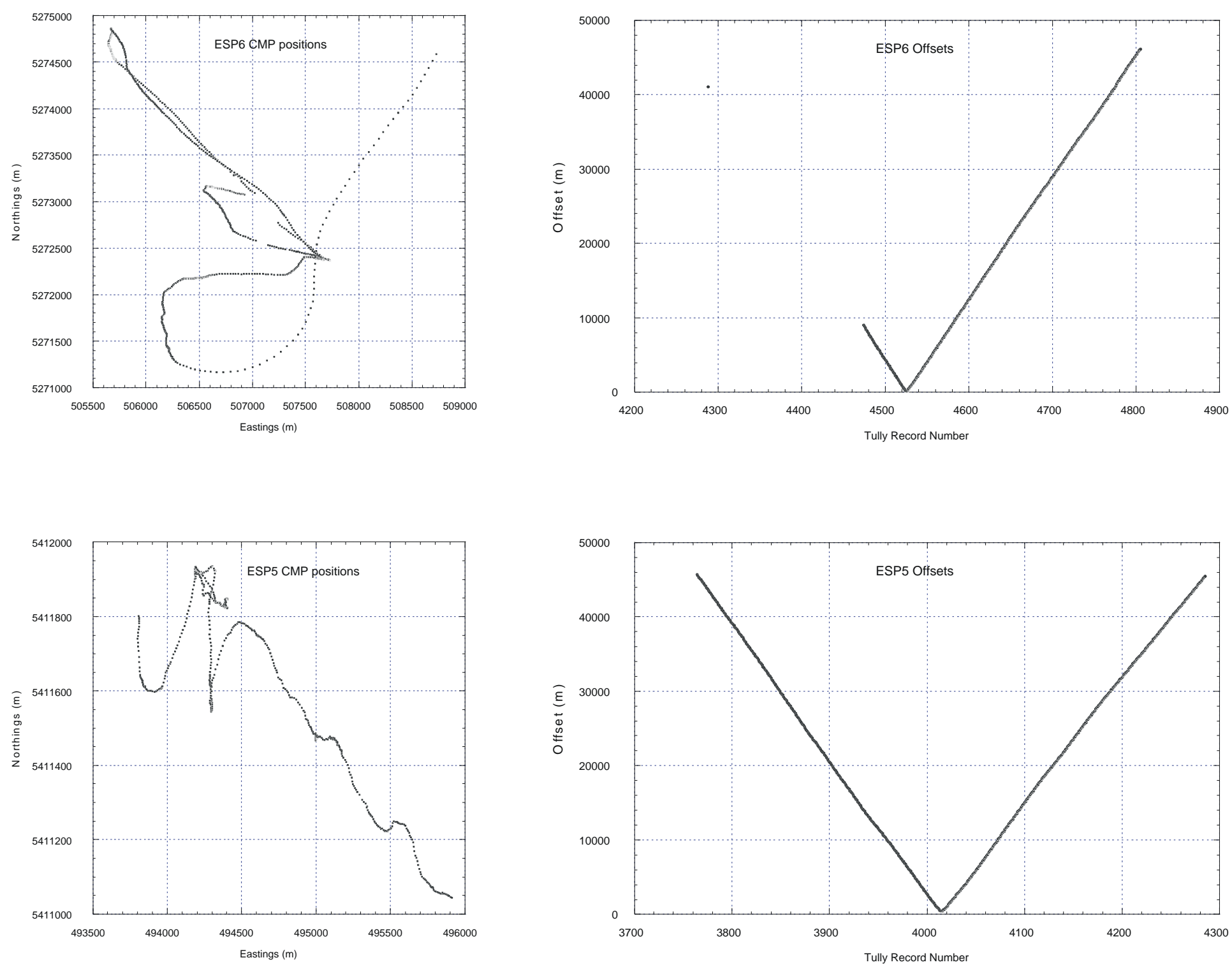

Figure 8. Maps showing distribution of common midpoints (left) and receiver offsets as a function of R/V Tully record number (right) for ESPs 6 and 5. 

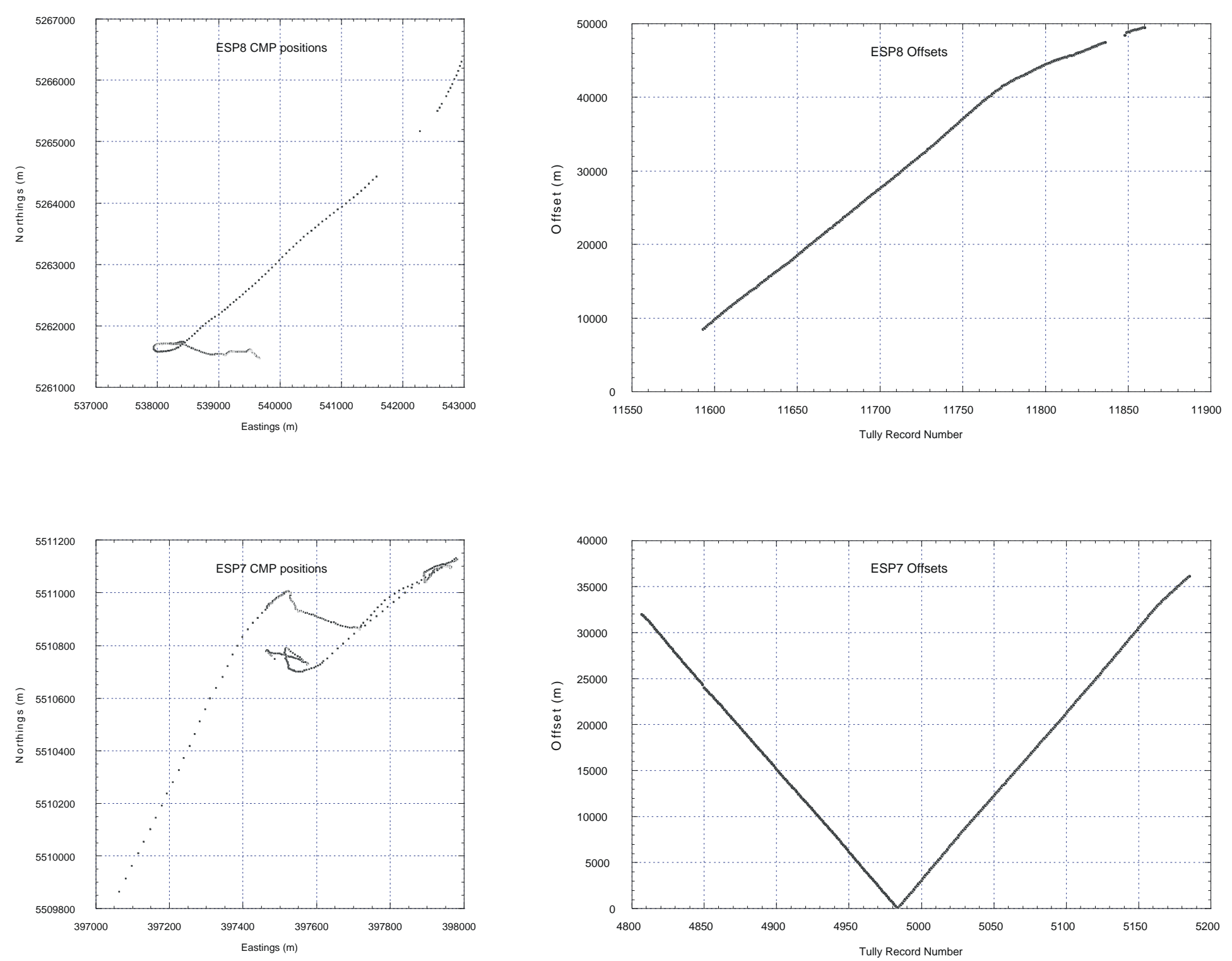

Figure 9. Maps showing distribution of common midpoints (left) and receiver offsets as a function of R/V Tully record number (right) for ESPs 8 and 7. 

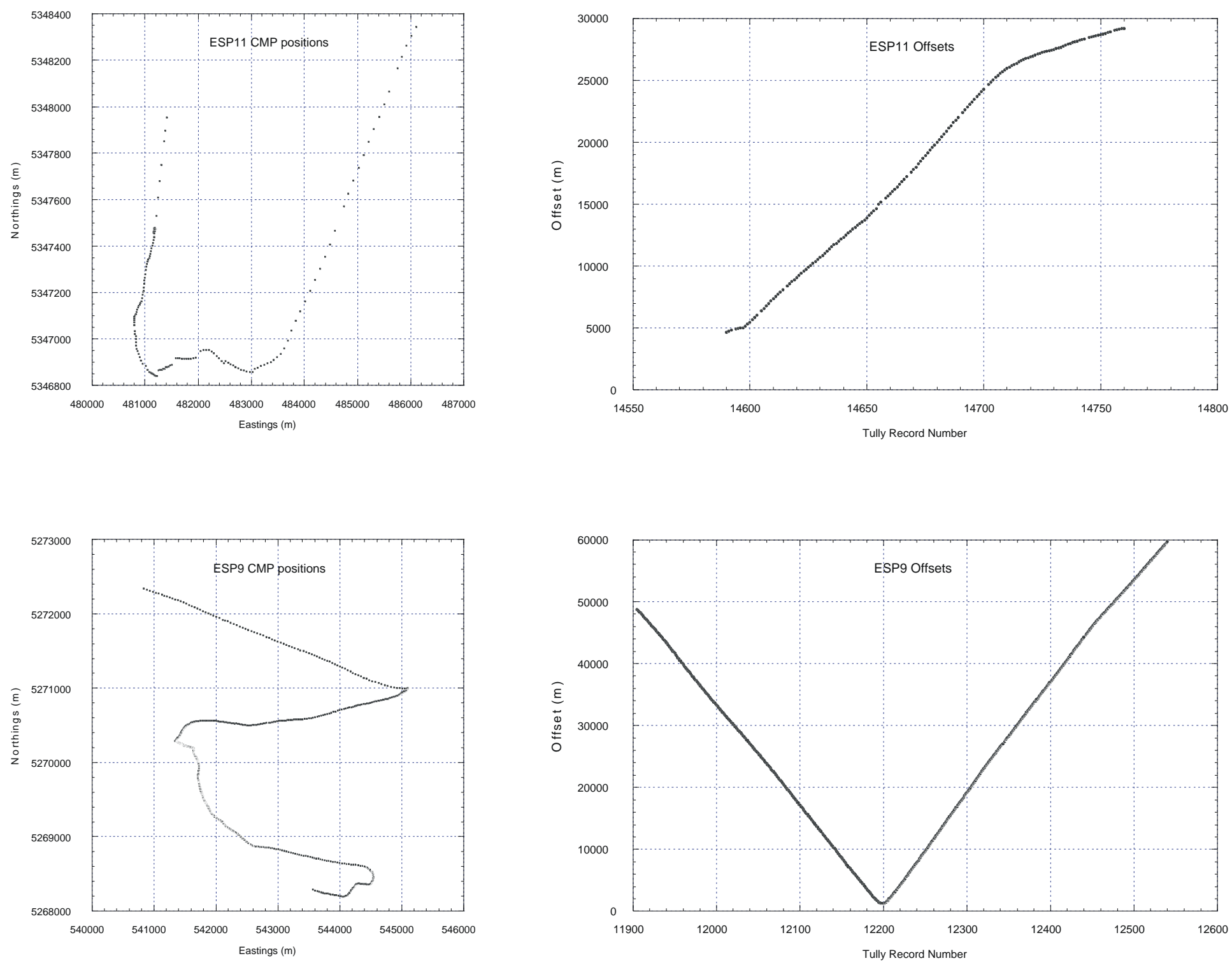

Figure 10. Maps showing distribution of common midpoints (left) and receiver offsets as a function of R/V Tully record number (right) for ESPs 10 and 9. 

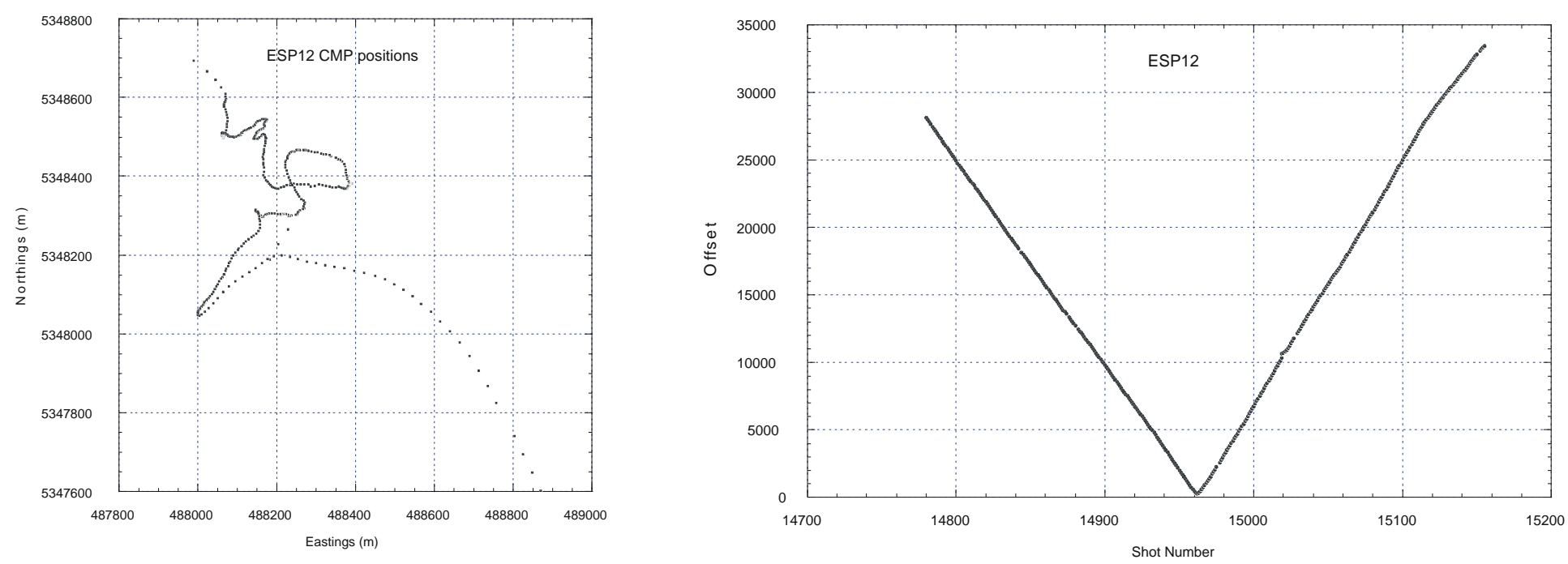

Figure 11. Map showing distribution of common midpoints (left) and receiver offsets as a function of R/V Tully record number (right) for ESP 12. 


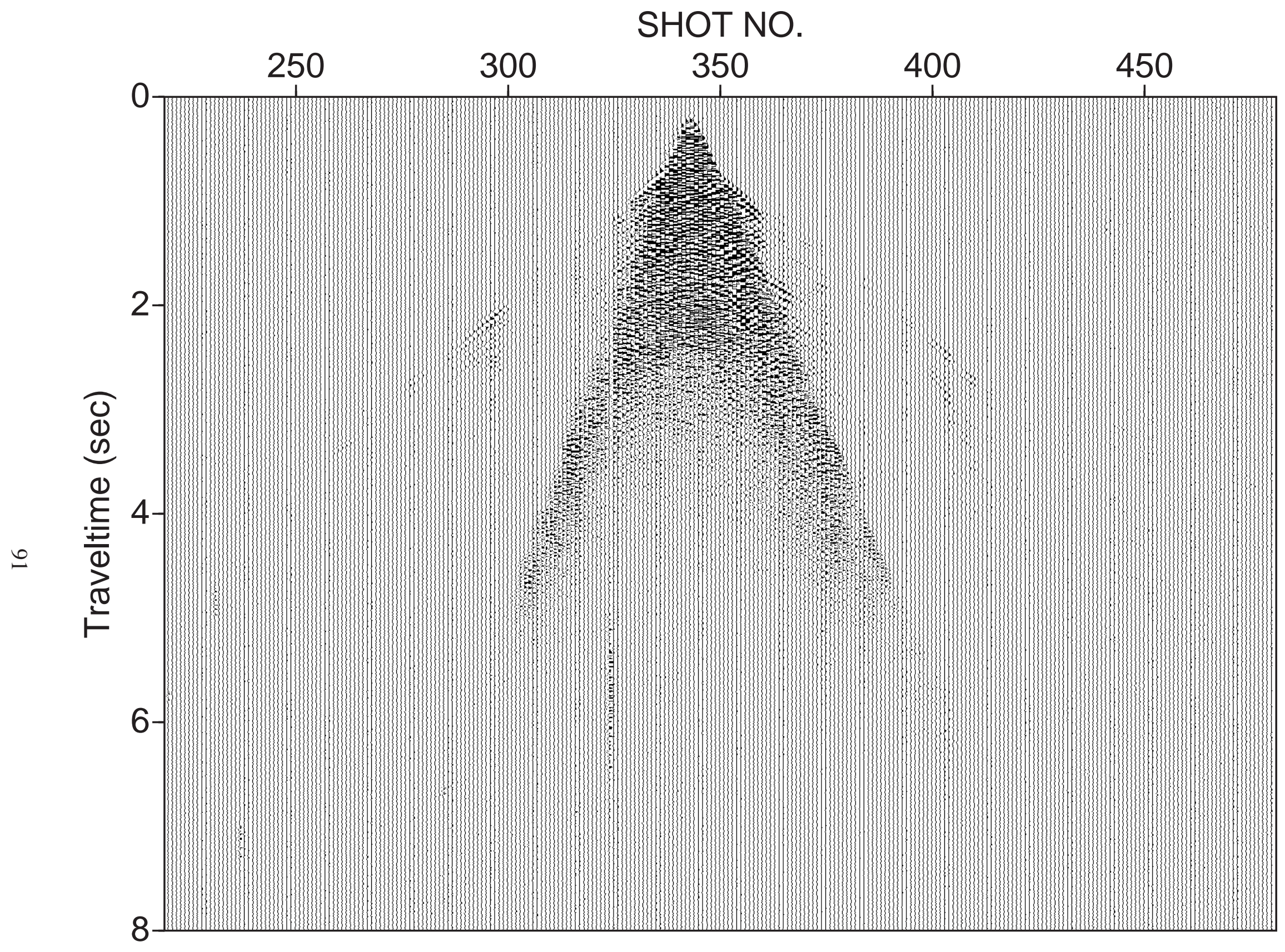

Figure 12. Record section for ESP 1 in Hood Canal. 


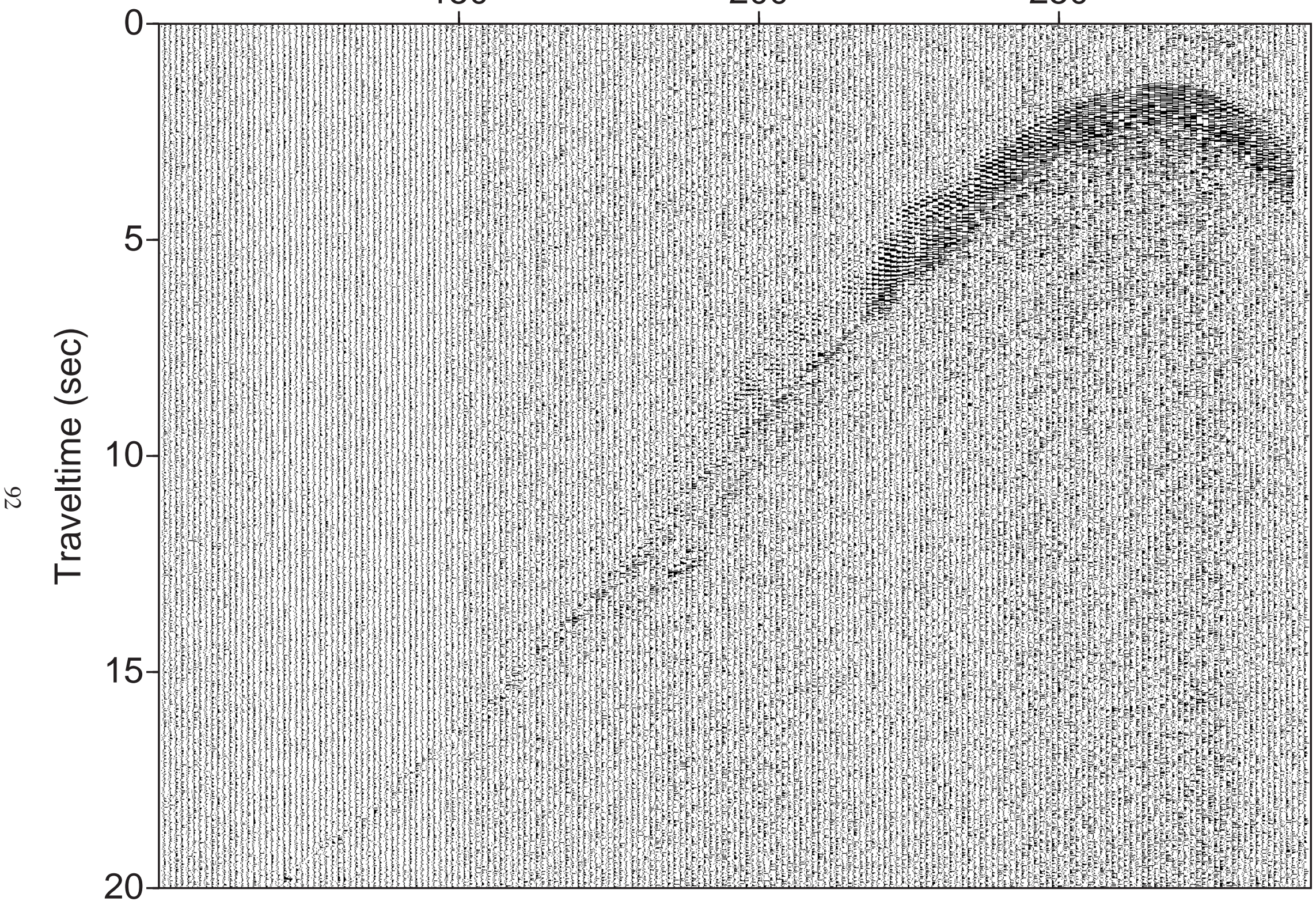

Figure 13. Record section for ESP 2 in the eastern Strait of Juan de Fuca. 
SHOT NO.

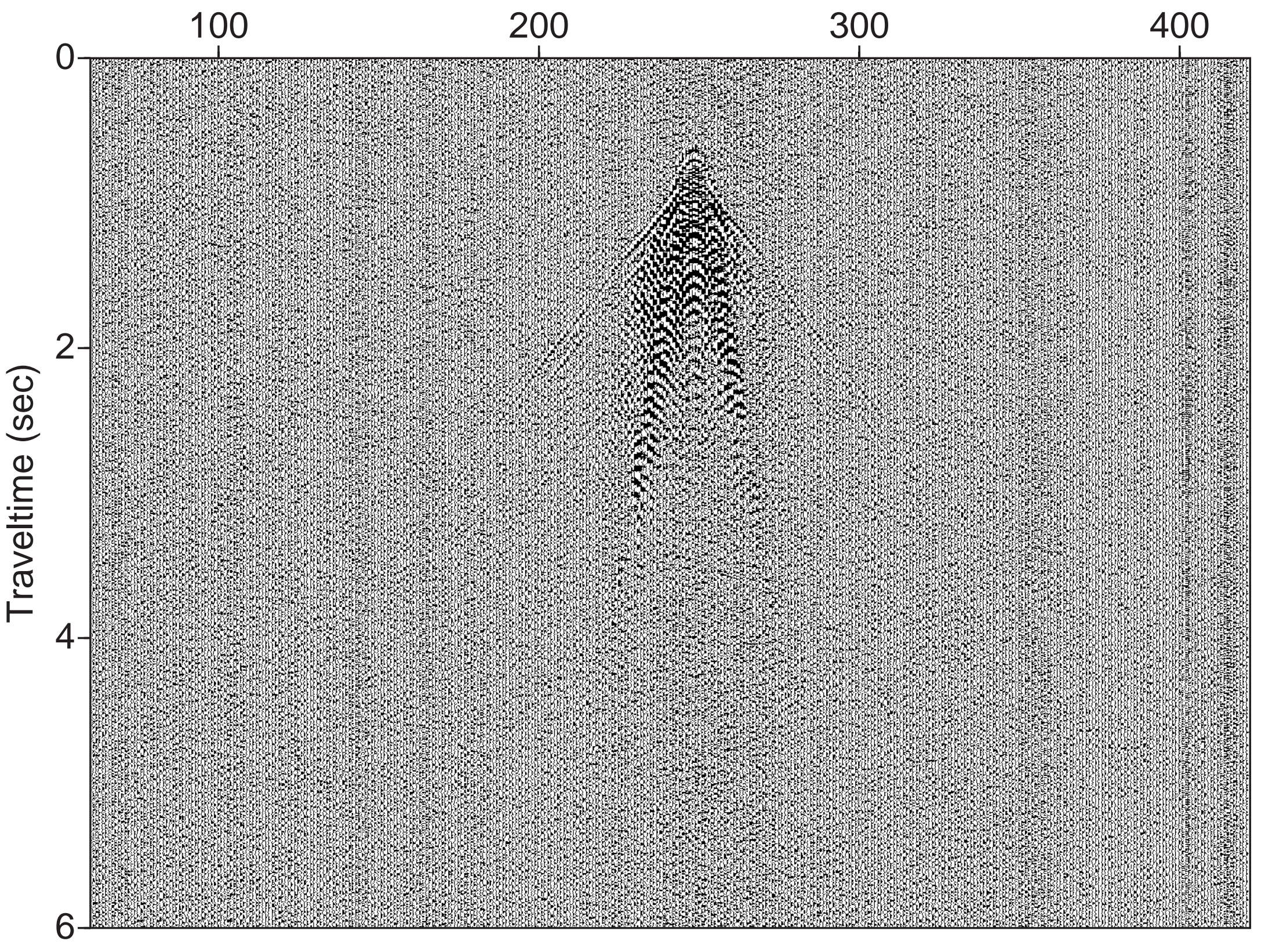

Figure 14. Record section for ESP 3 in the western Strait of Juan de Fuca. 


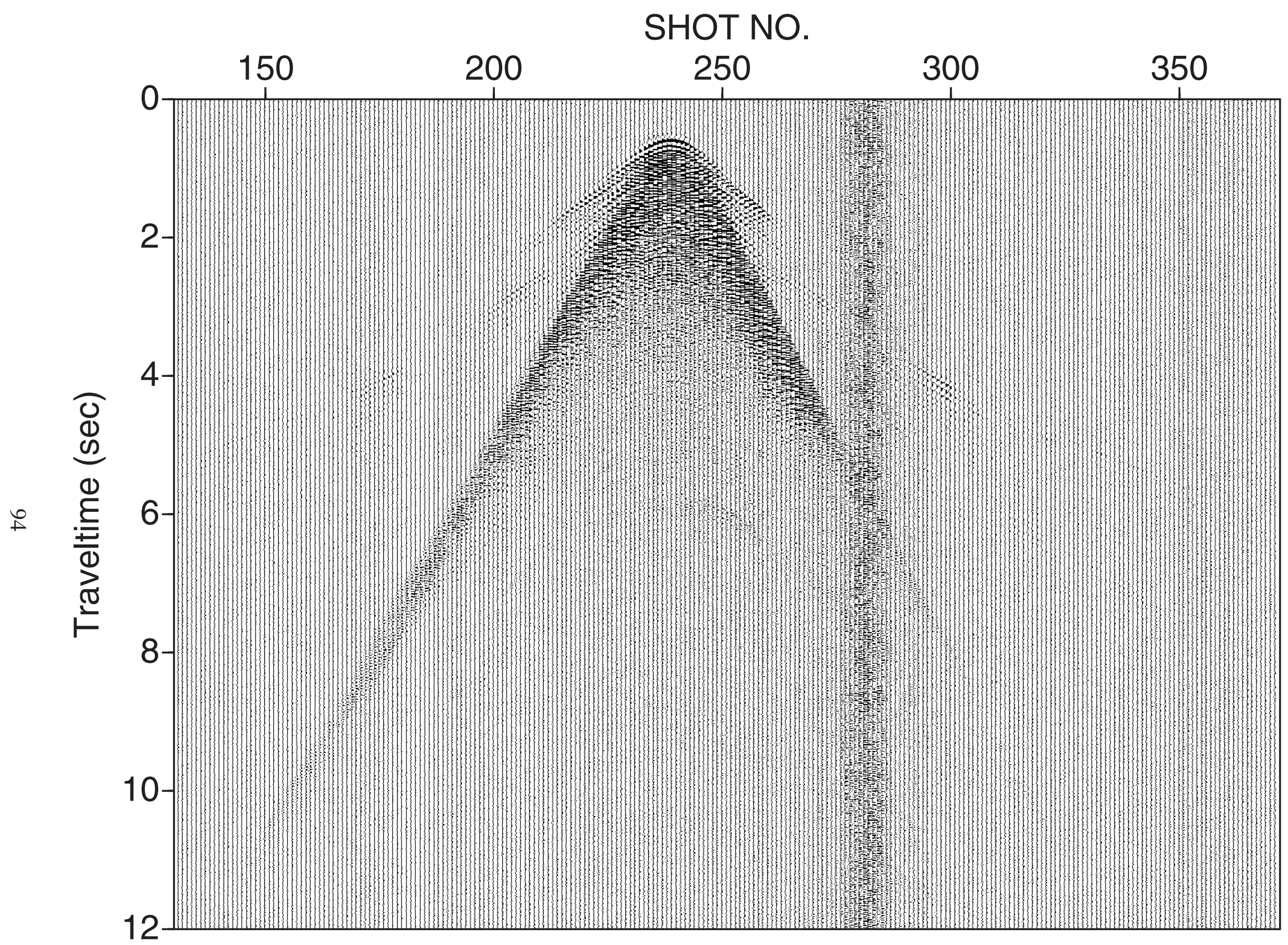

Figure 15. Record section for ESP 4 in the western Strait of Juan de Fuca. 


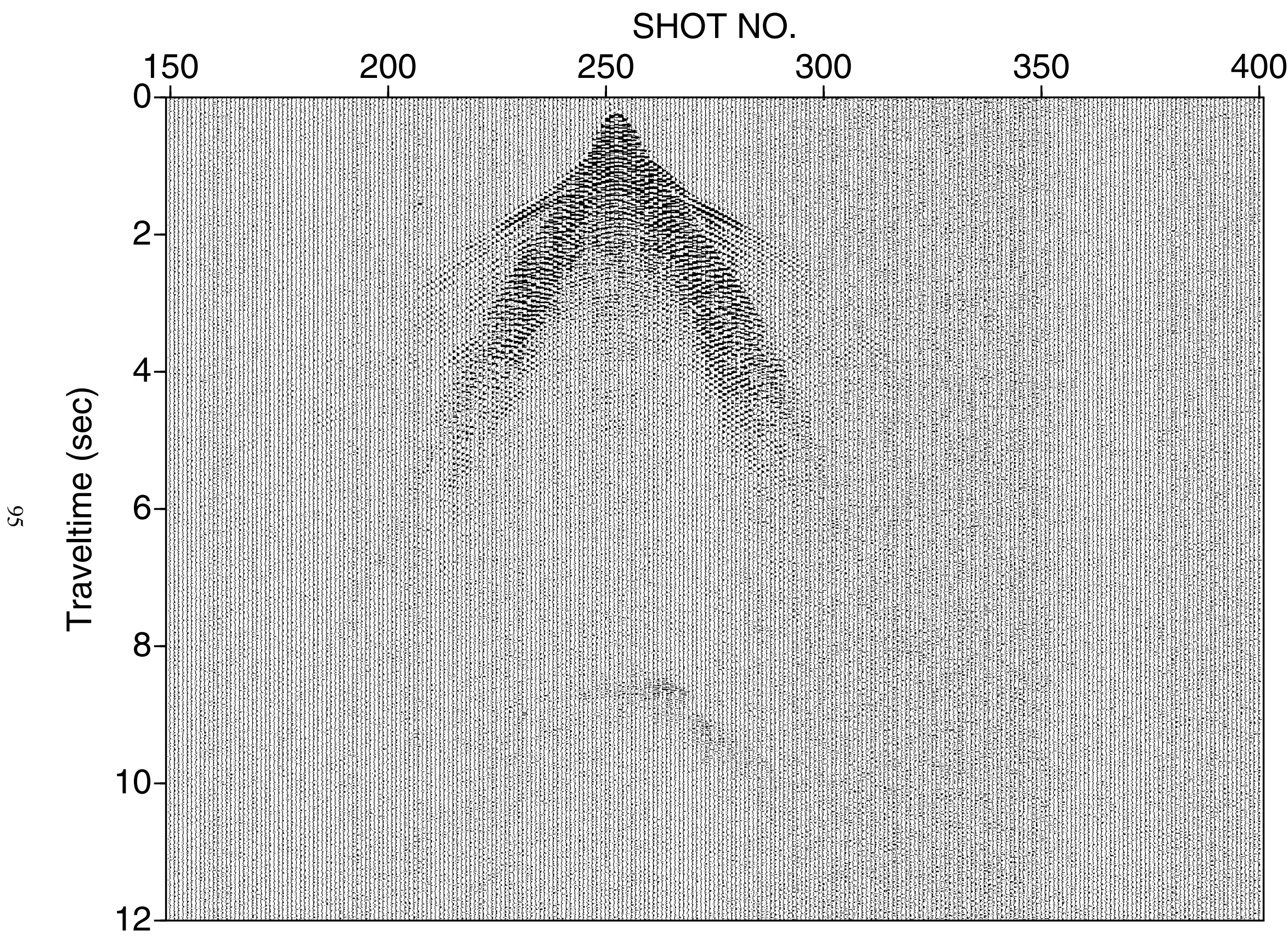

Figure 16. Record section for ESP 5 in the southern Strait of Georgia. 


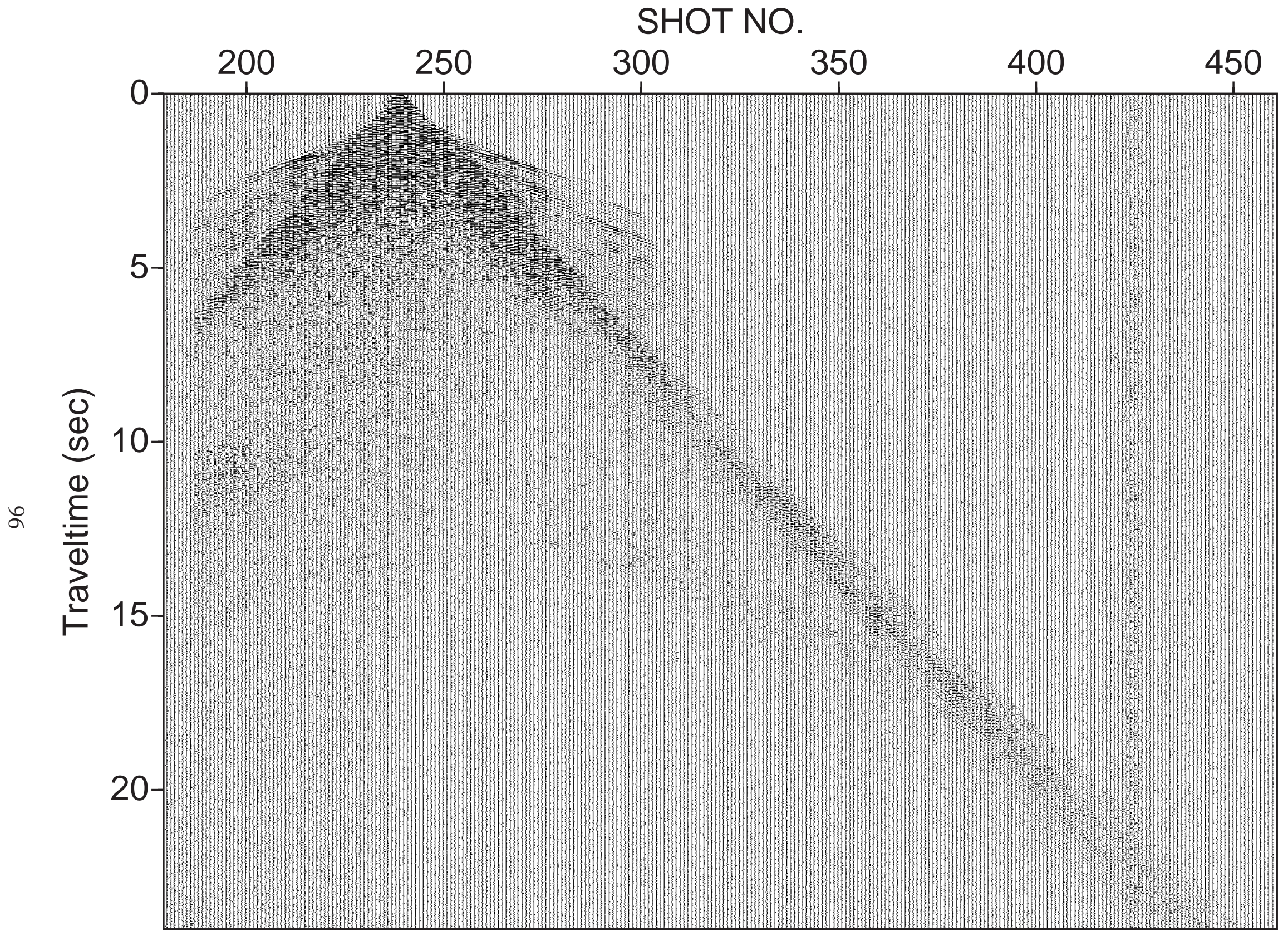

Figure 17. Record section for ESP 6 in the Strait of Georgia. 


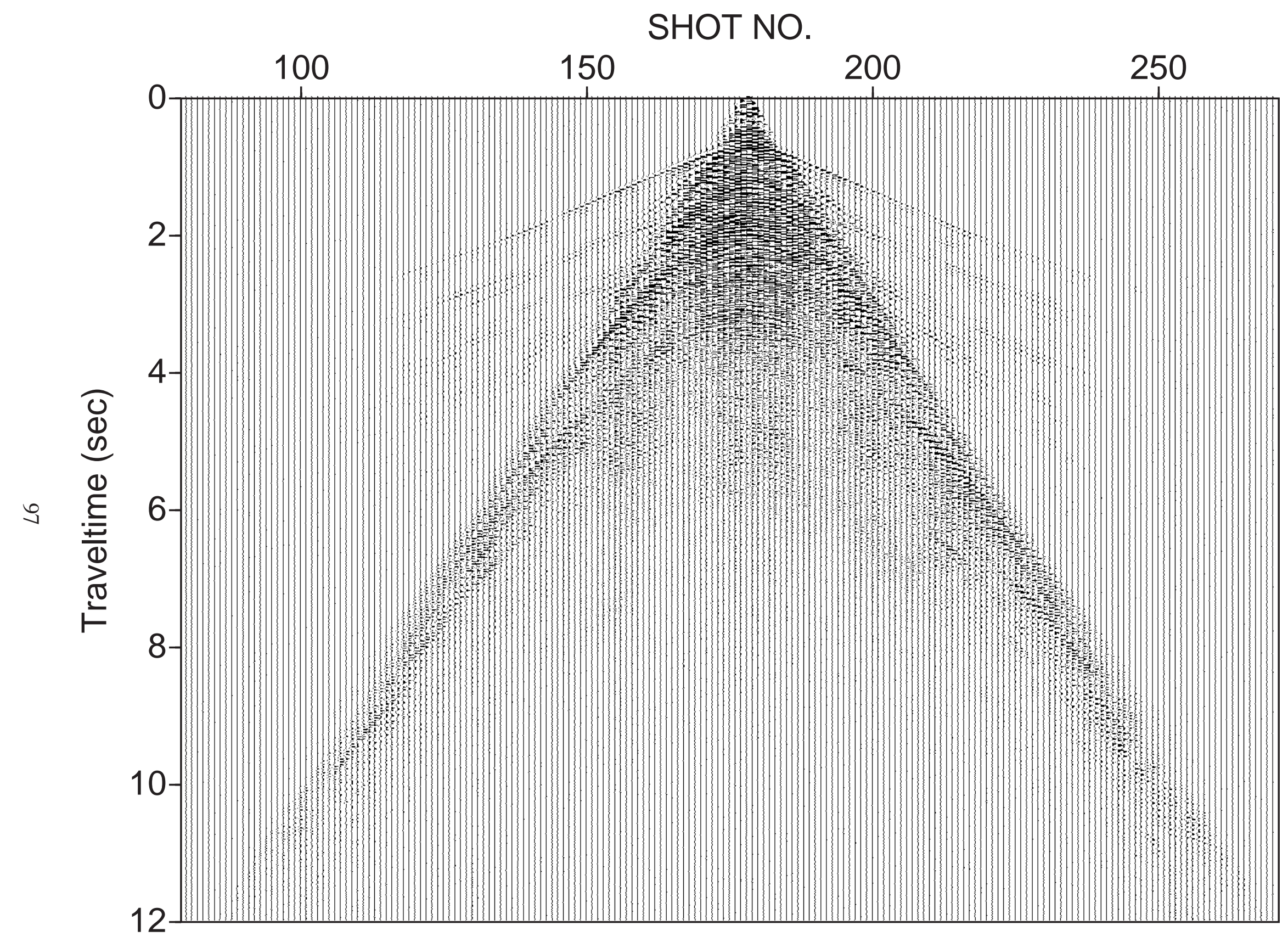

Figure 18. Record section for ESP 7 in the Strait of Georgia. 


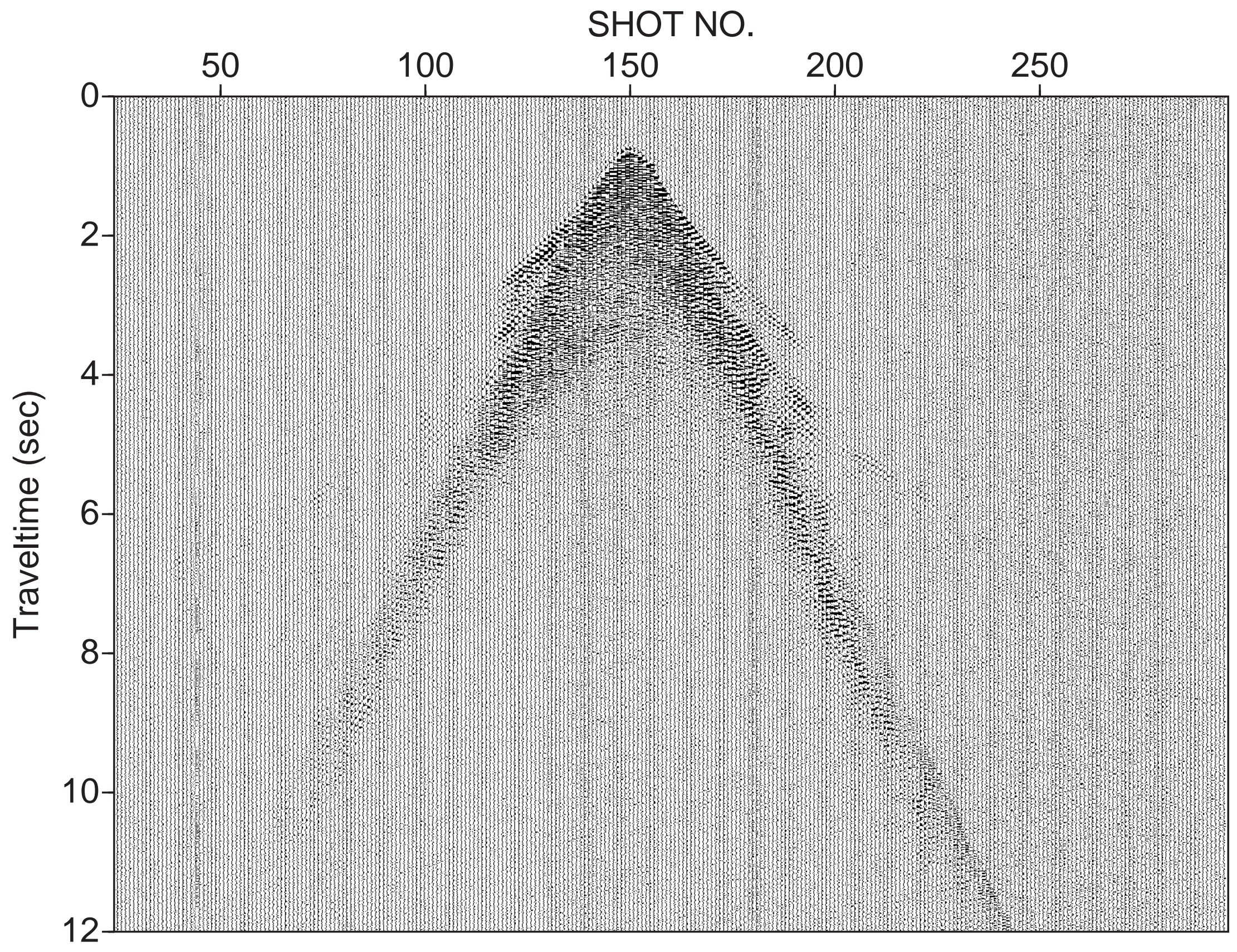

Figure 19. Record section for ESP 9 in Puget Sound. 


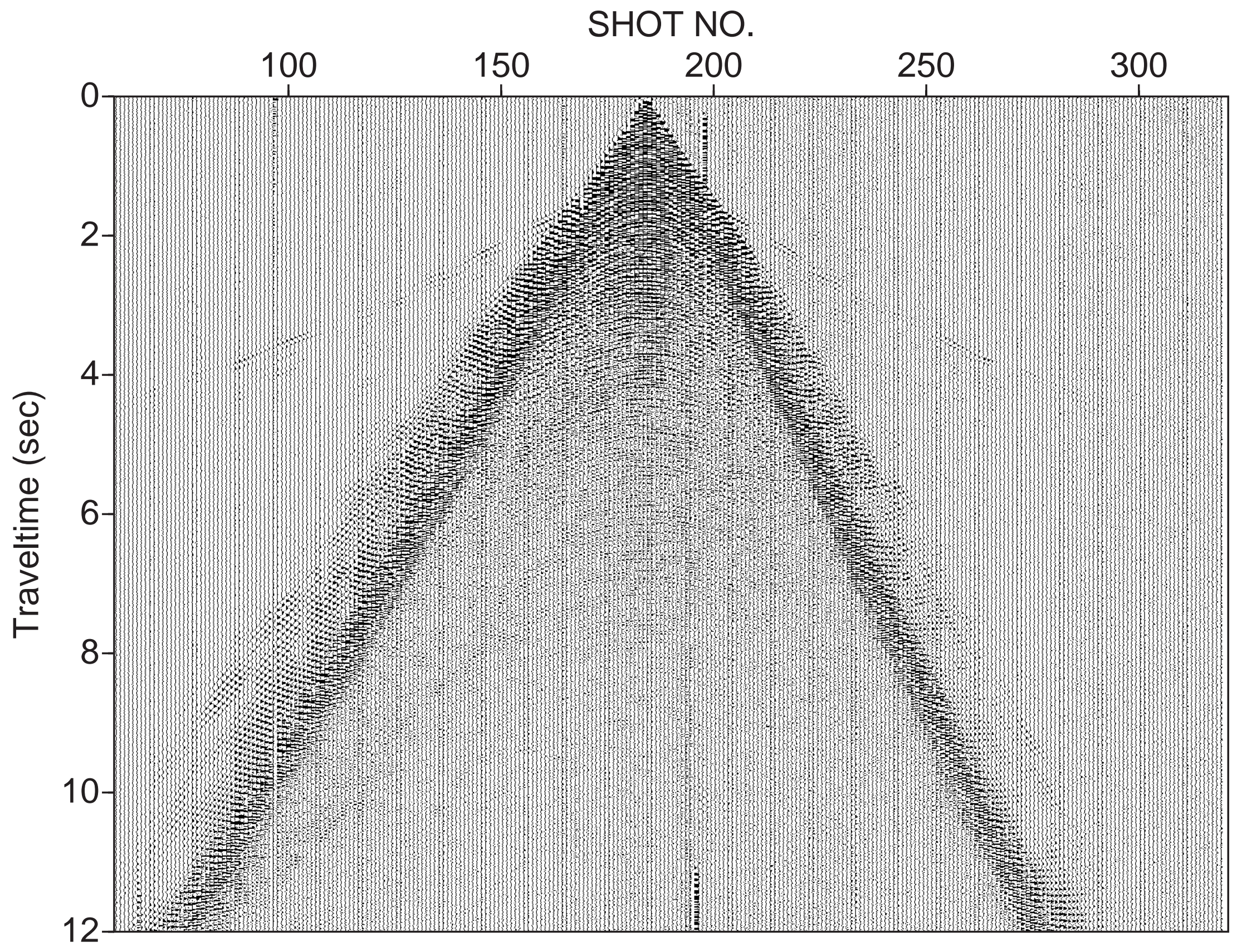

Figure 20. Record section for ESP 12 in the eastern Strait of Juan de Fuca. 


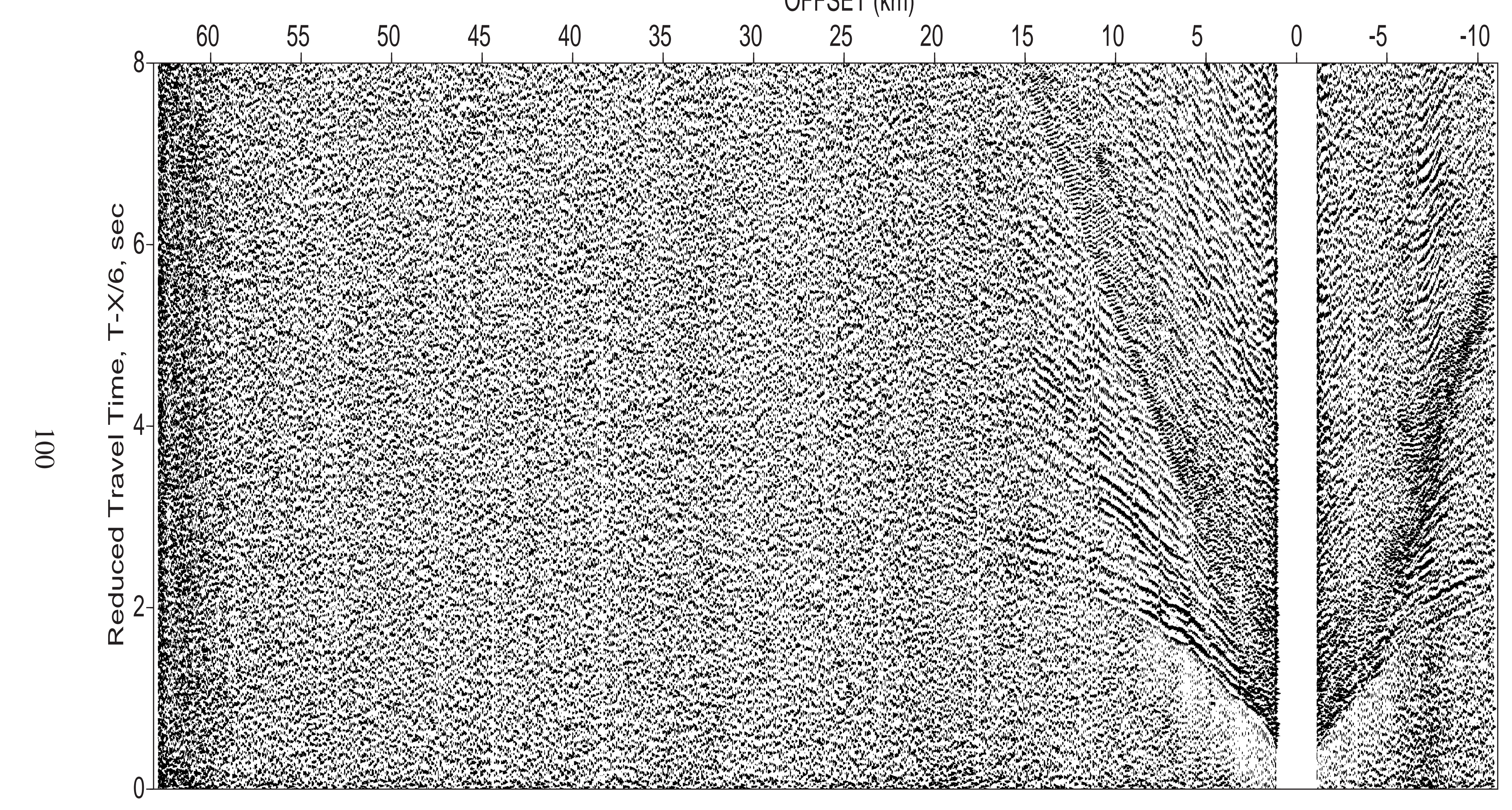

Figure 21. OBS record section for the vertical geophone component of USGS OBS1 (instrument c9) for airgun shots in Puget Sound. 


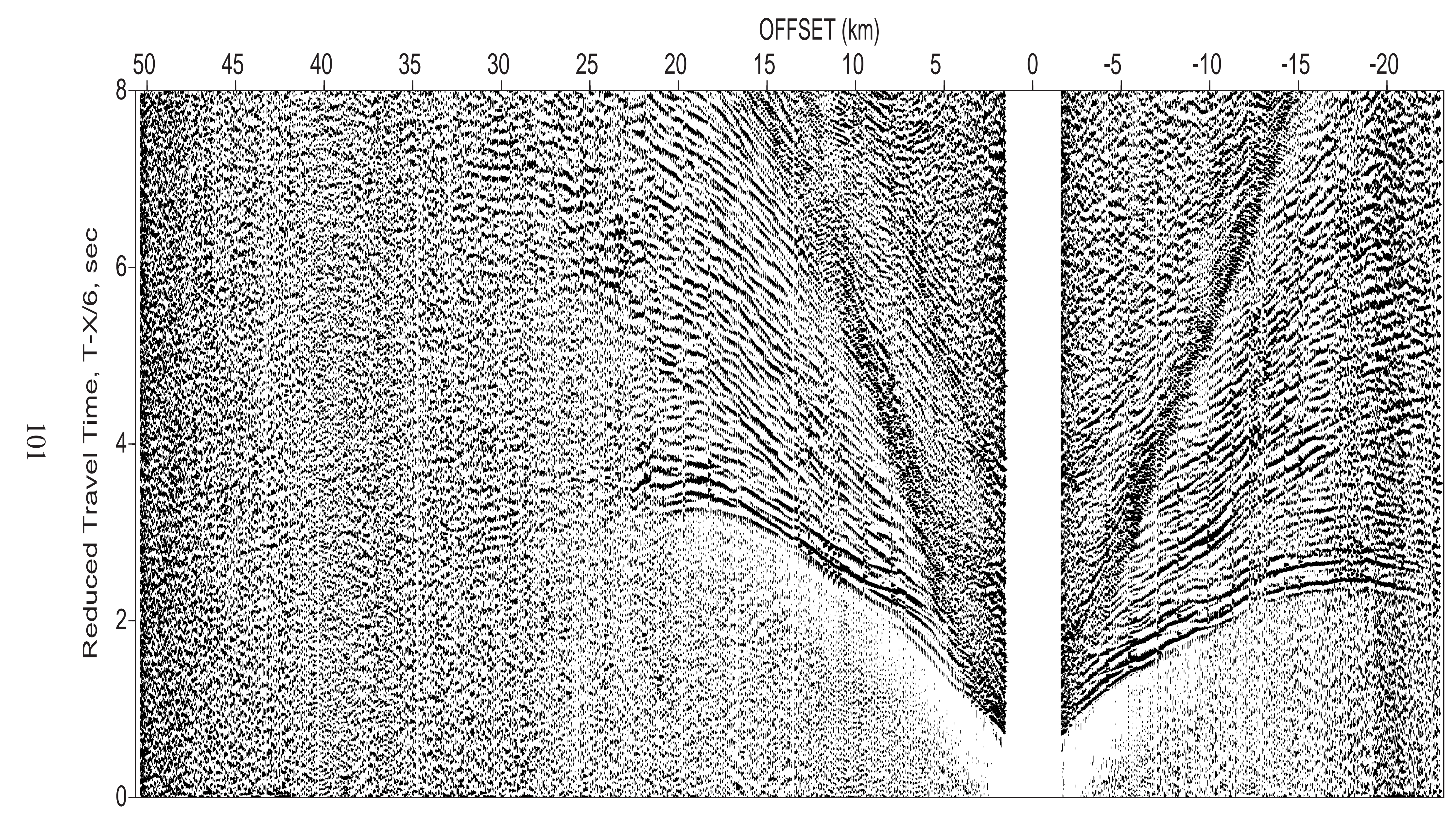

Figure 22. OBS record section for the hydrophone component of USGS OBS3 (instrument a1) for airgun shots in Puget Sound. 


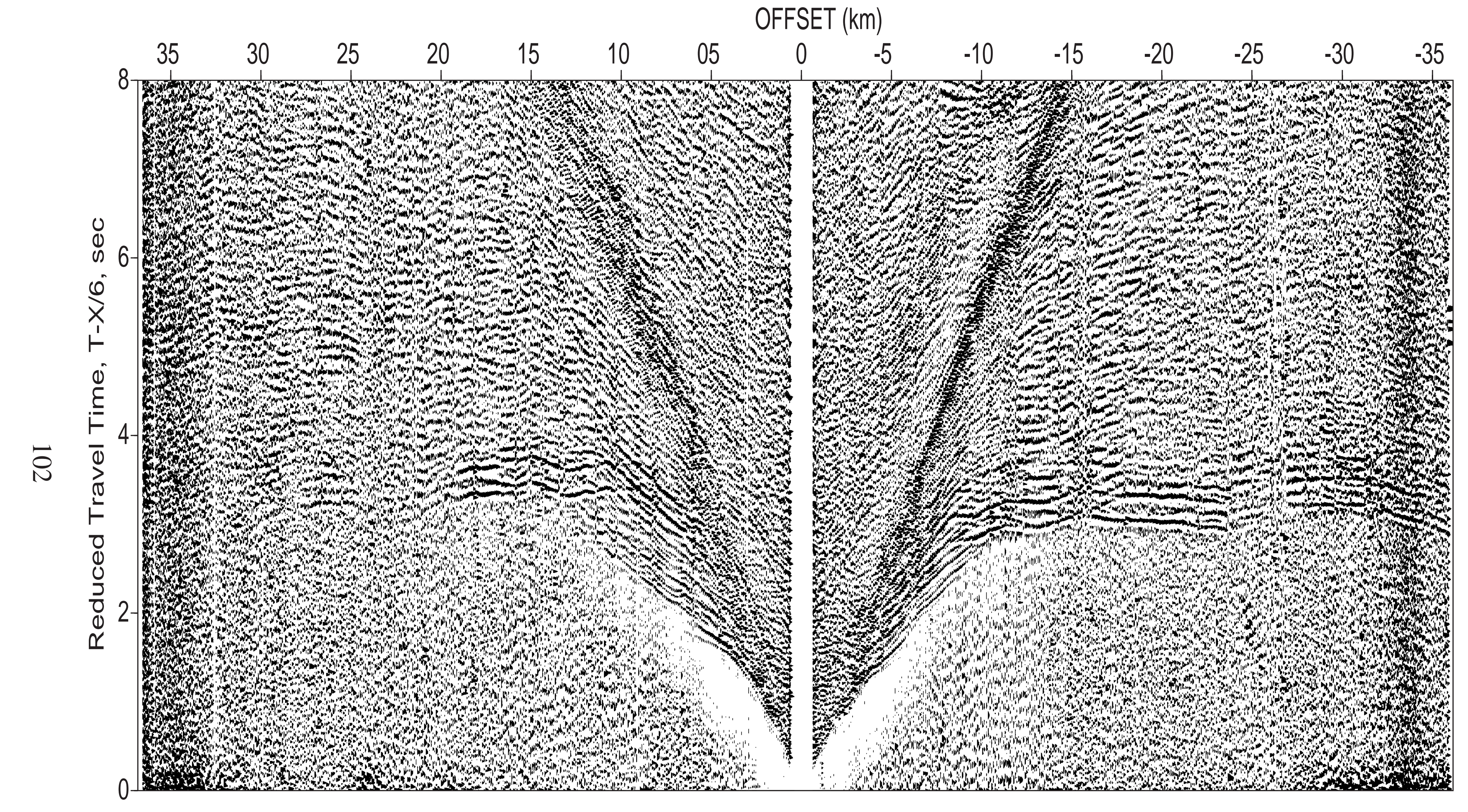

Figure 23. OBS record section for the vertical geophone component of USGS OBS5 (instrument d1) for airgun shots in Puget Sound. 


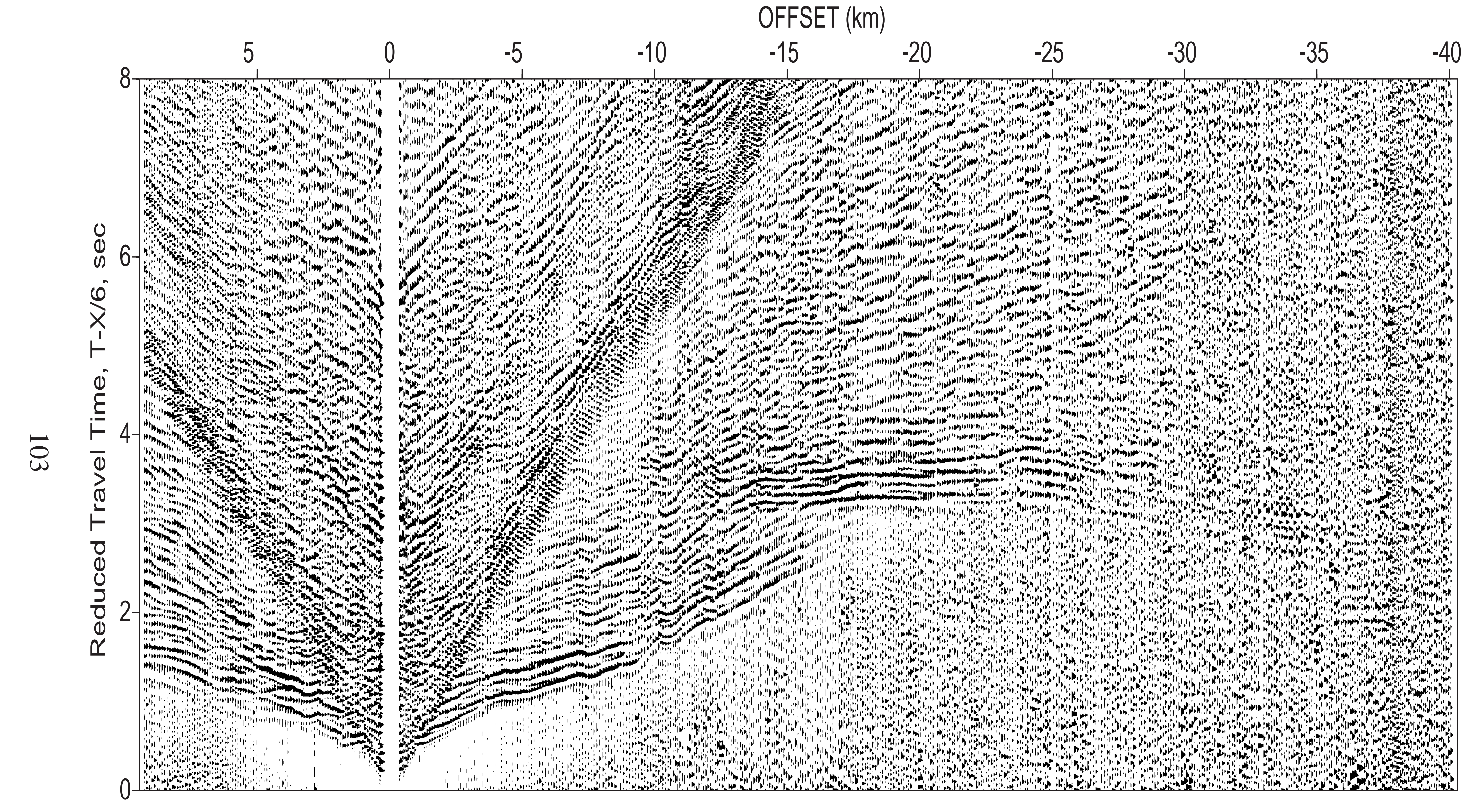

Figure 24. OBS record section for the vertical geophone component of USGS OBS7 (instrument a8) for airgun shots in Puget Sound. 


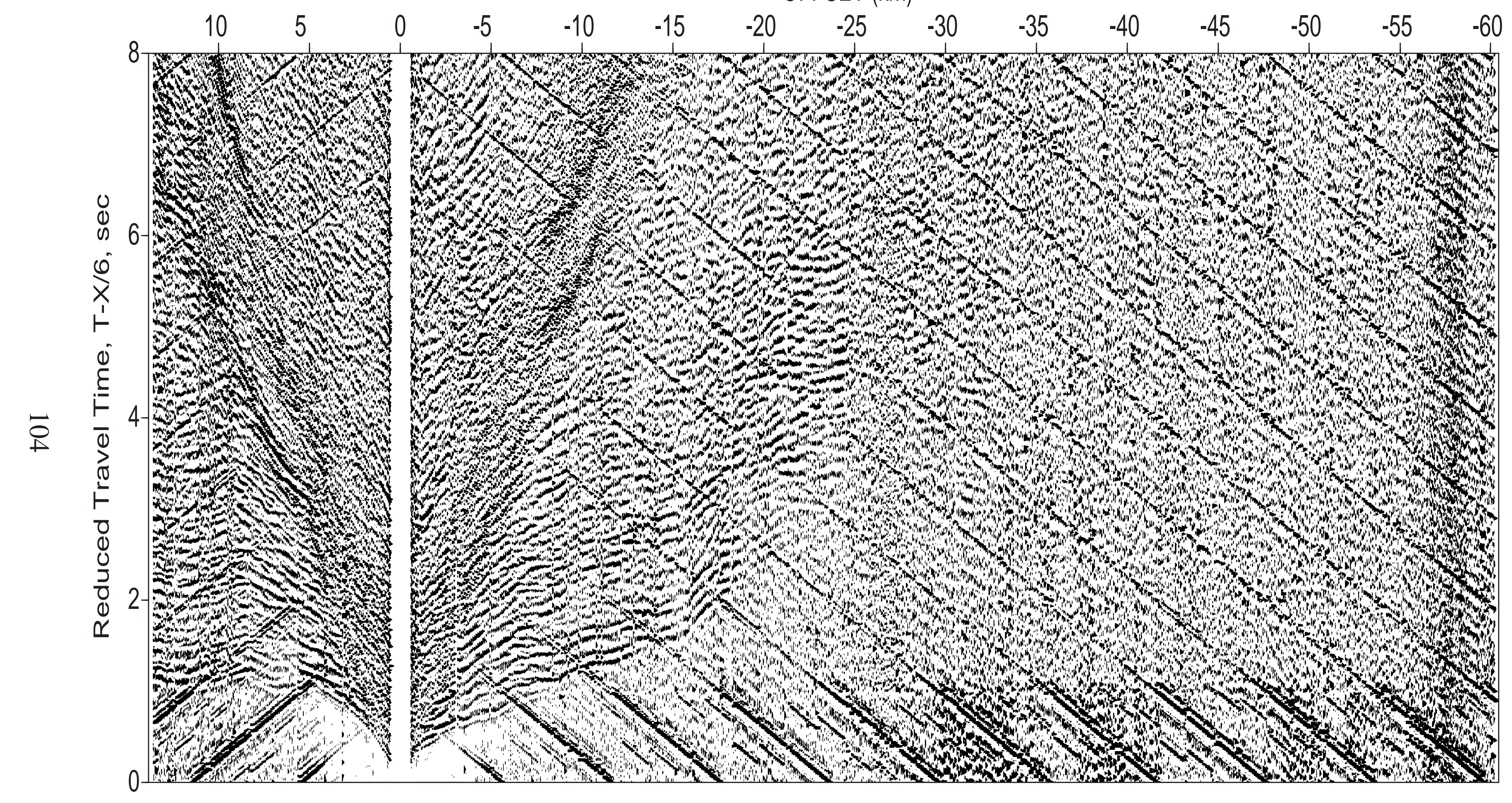

Figure 25. OBS record section for the vertical geophone component of USGS OBS8 (instrument c1) for airgun shots in Puget Sound. 
South

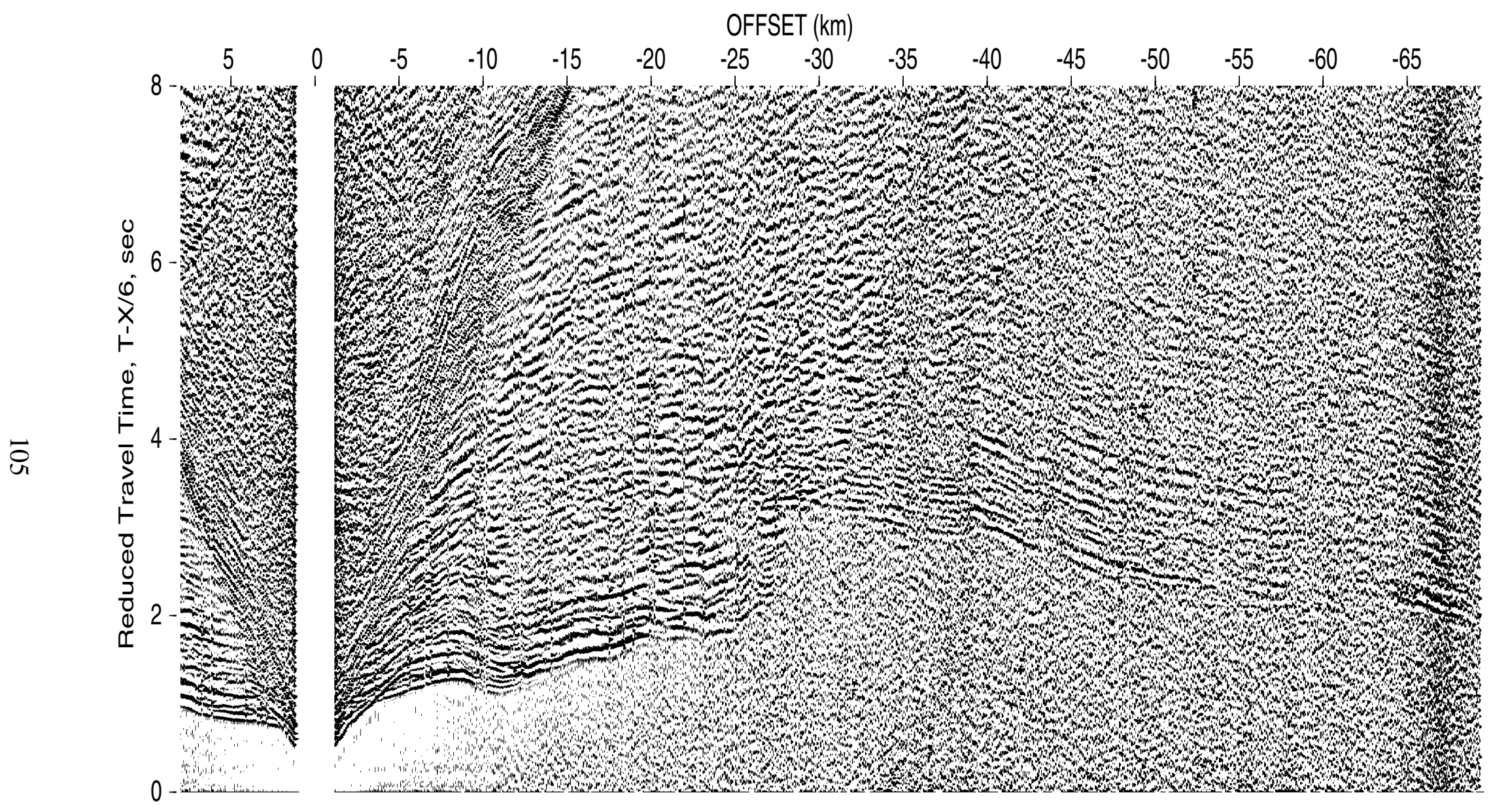

Figure 26. OBS record section for the hydrophone component of USGS OBS9 (instrument a4) for airgun shots in Puget Sound. 


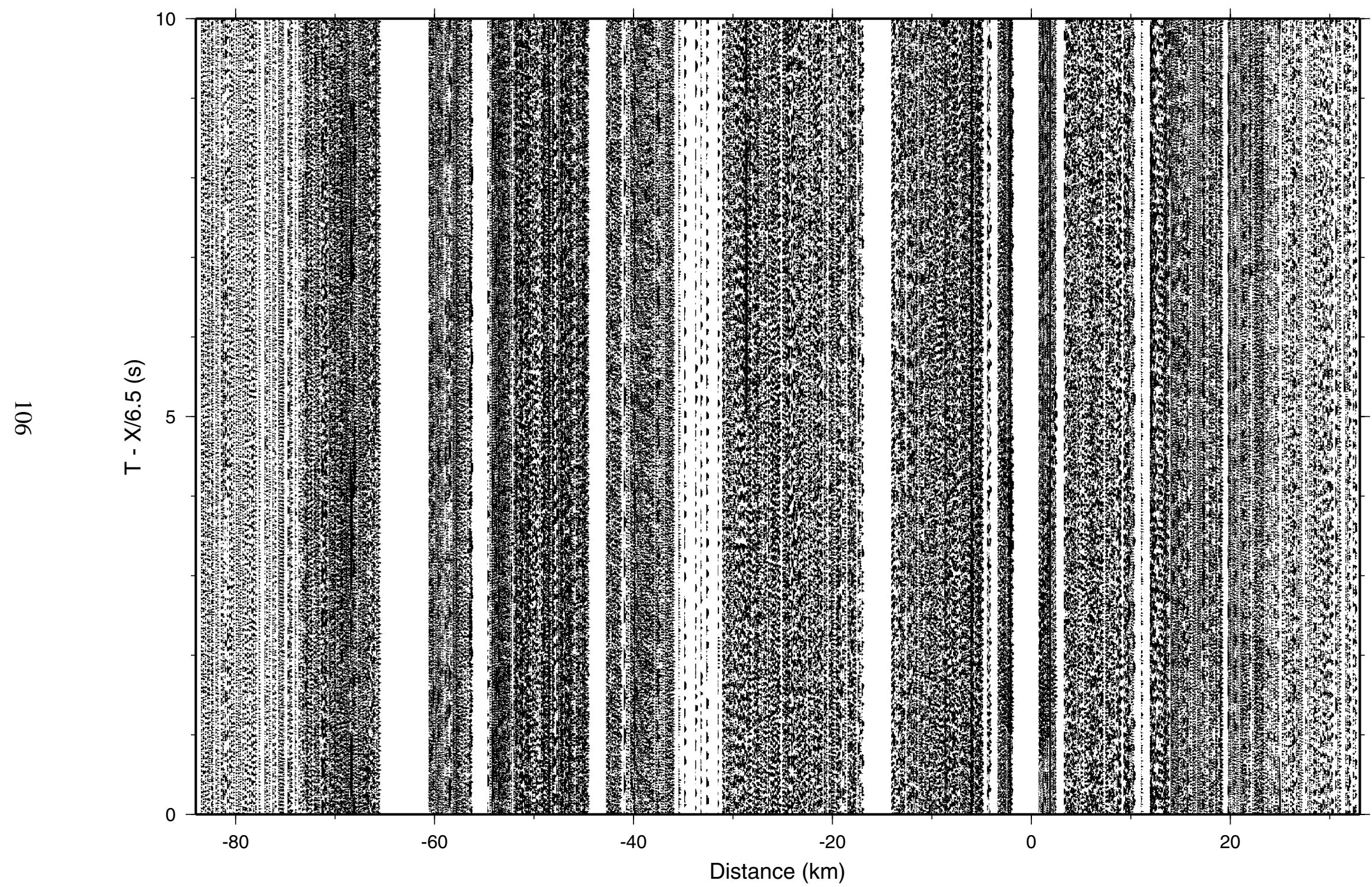

Figure 27. Reduced record section for Shotpoint 24a, vertical component only, for Lines 1 and 2. 


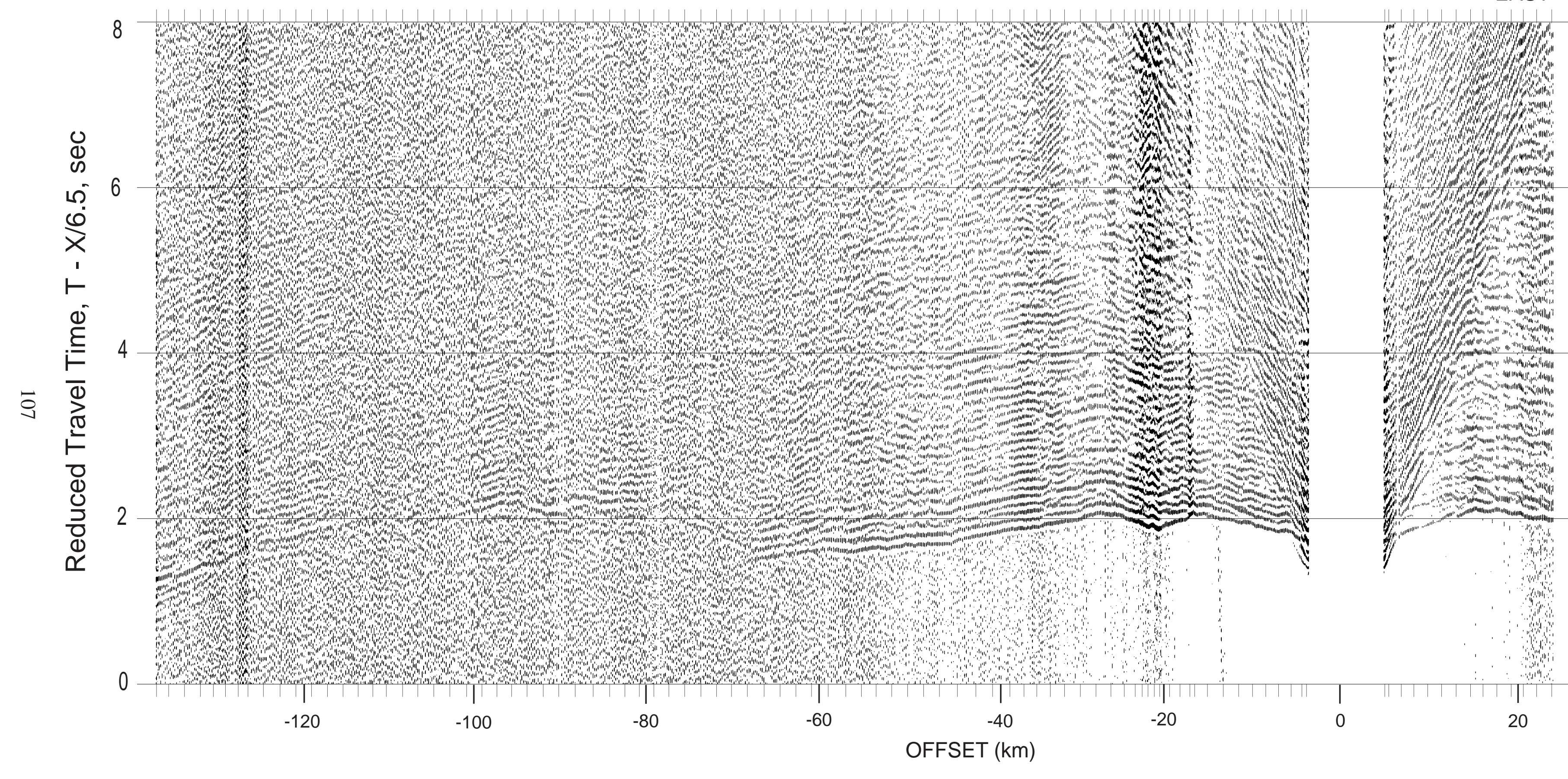

Figure 28. Reftek record section for the vertical geophone component of station OR06 (9006) for Line 4 in the Strait of Juan de Fuca. 


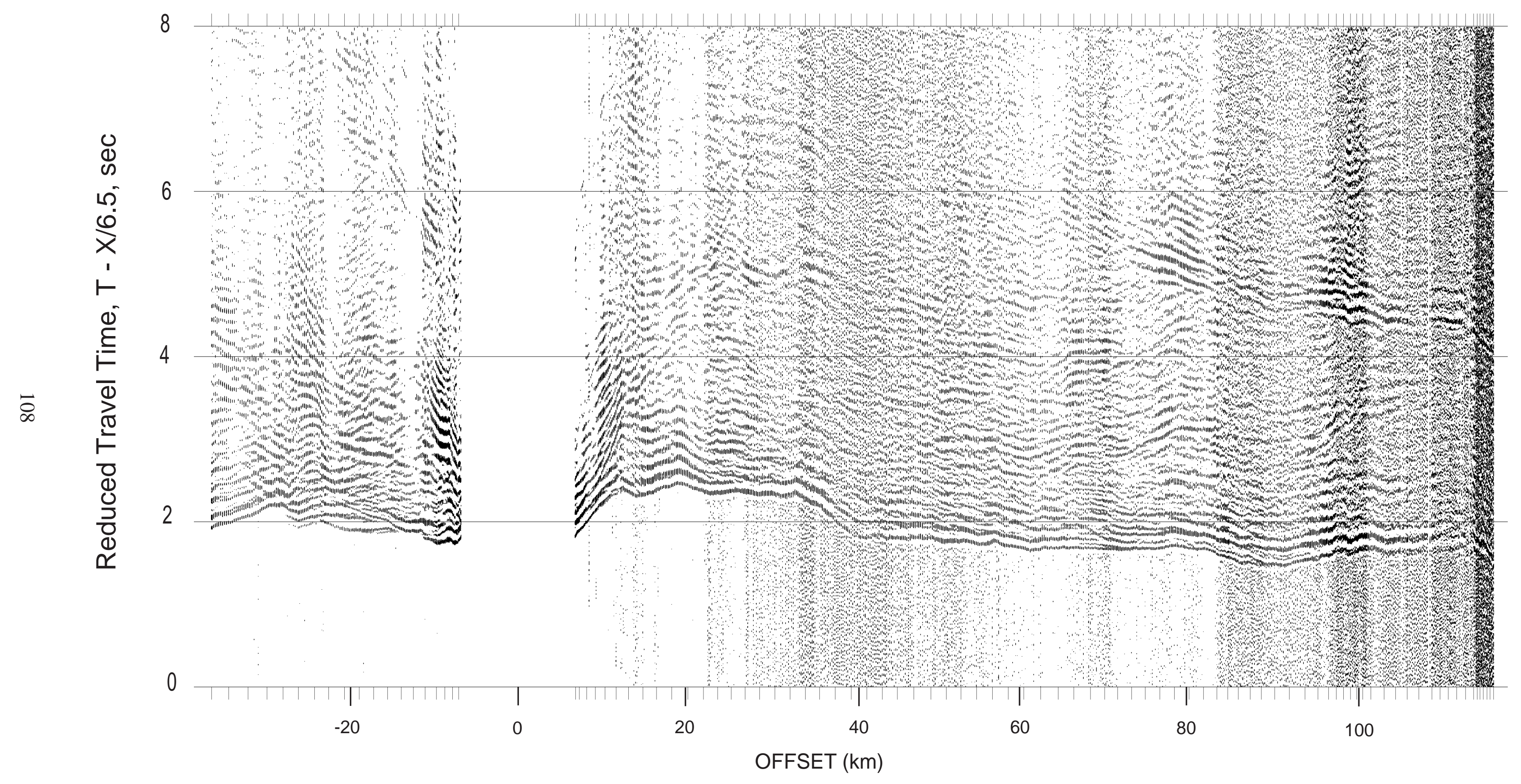

Figure 29. Reftek record section for the vertical component of site 9022 (OR22) for Line 4 in the Strait of Juan de Fuca. 


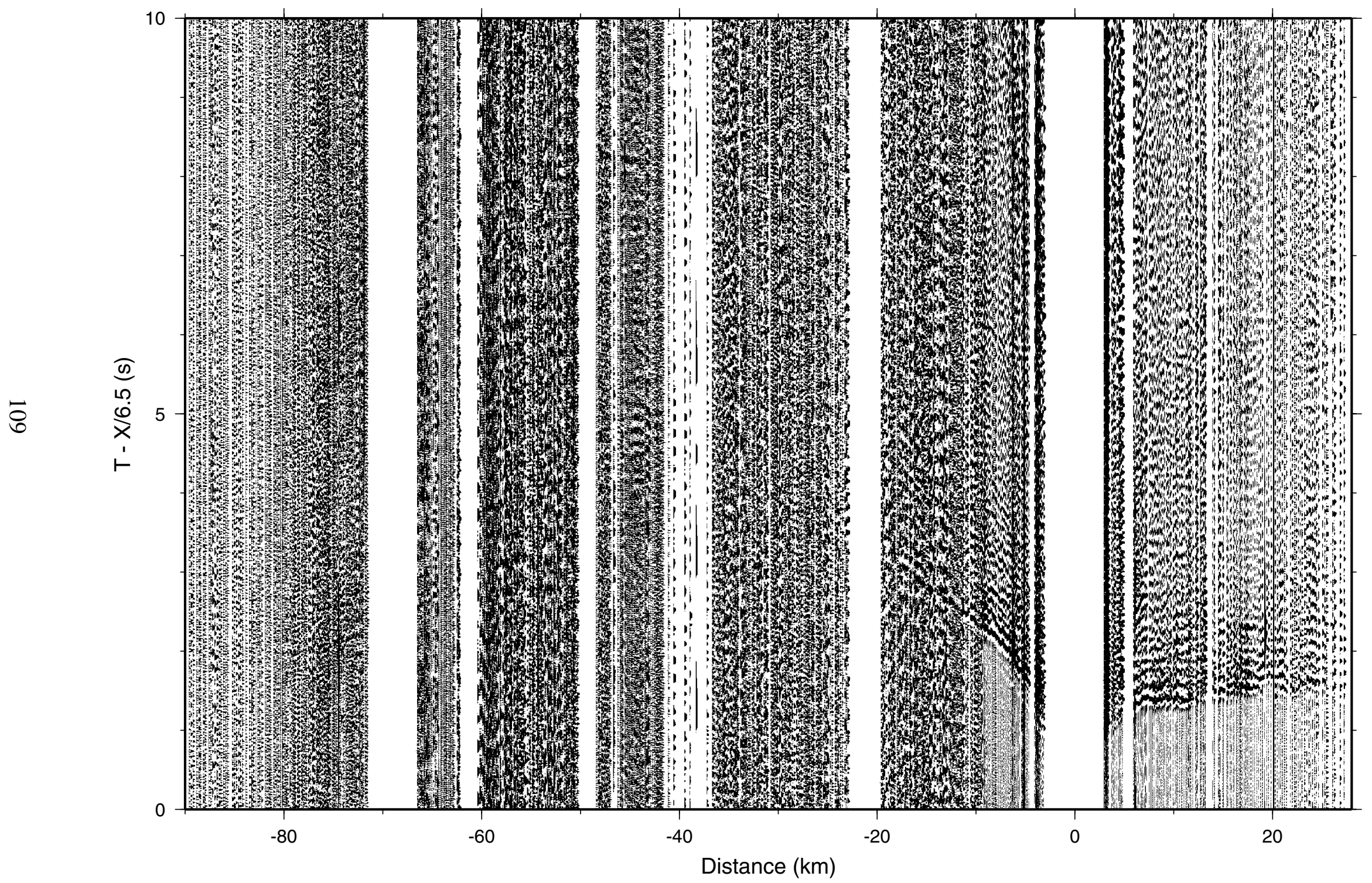

Figure 30. Reduced record section for Shotpoint 26b, vertical component only, for Lines 1 and 2. 


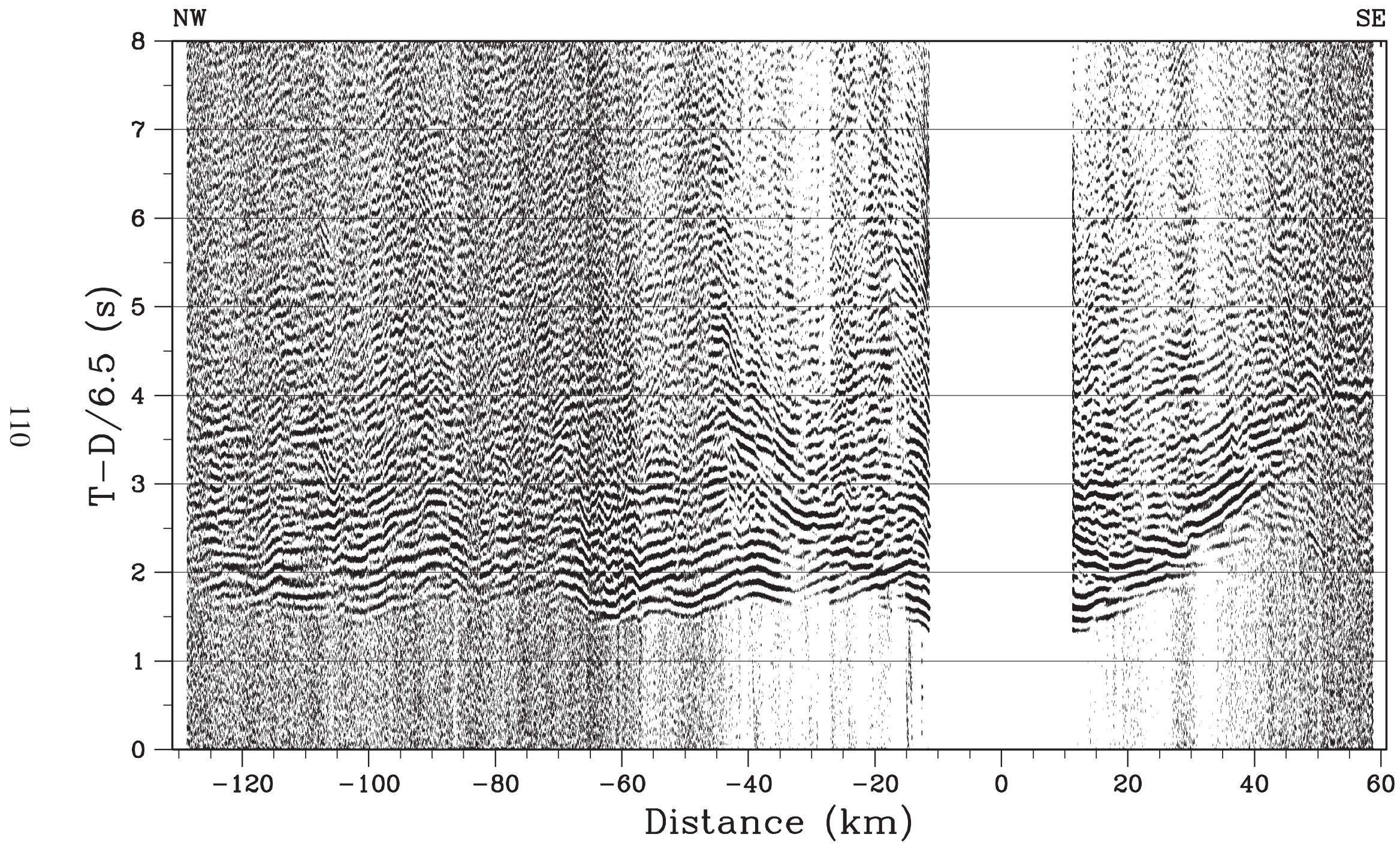

Figure 31. Record section for Reftek station CA19 (11019) for Line 6 in the Strait of Georgia. 


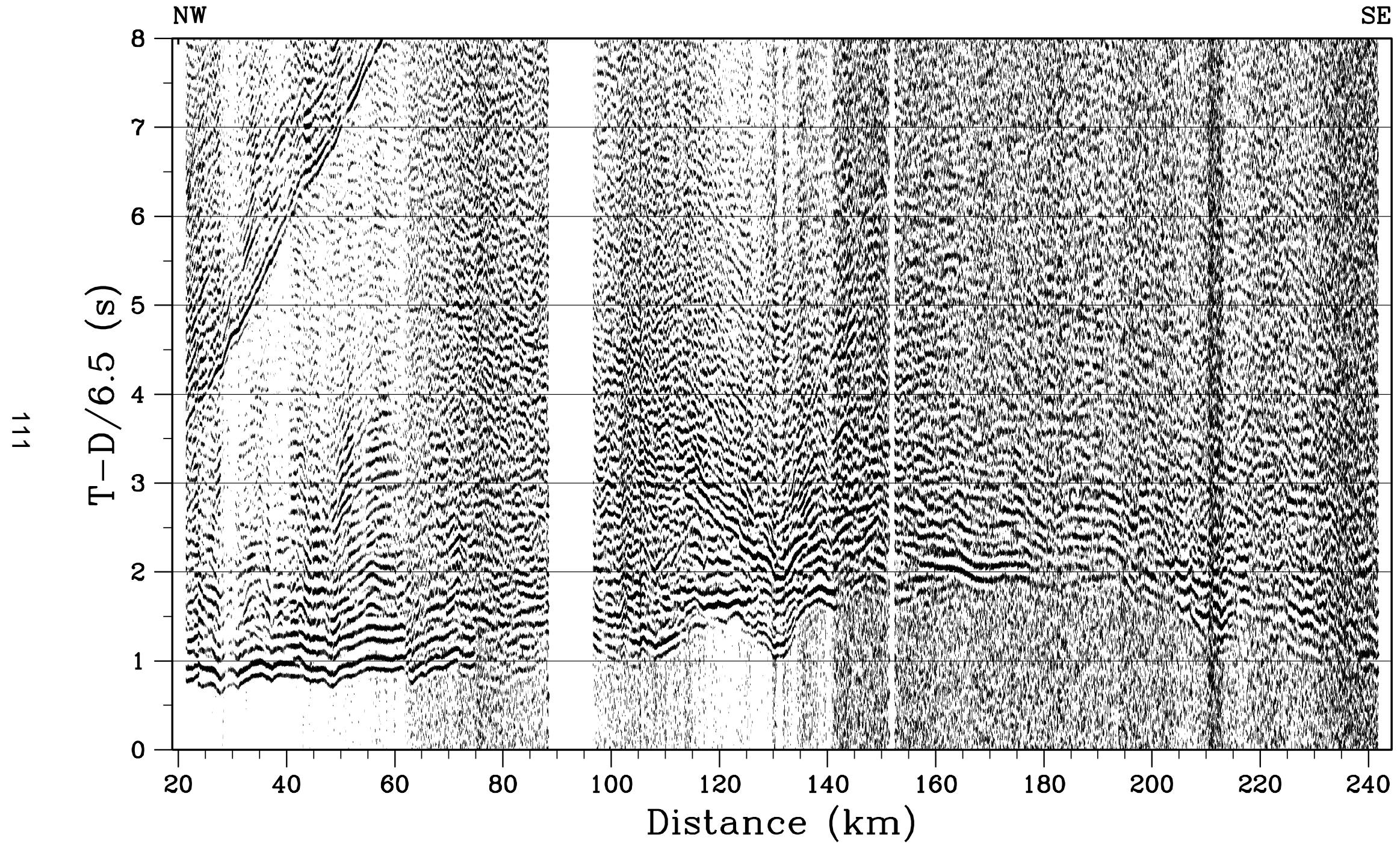

Figure 32. Record section for Reftek station CA50 (11050) for Line 5 in the Strait of Georgia. 


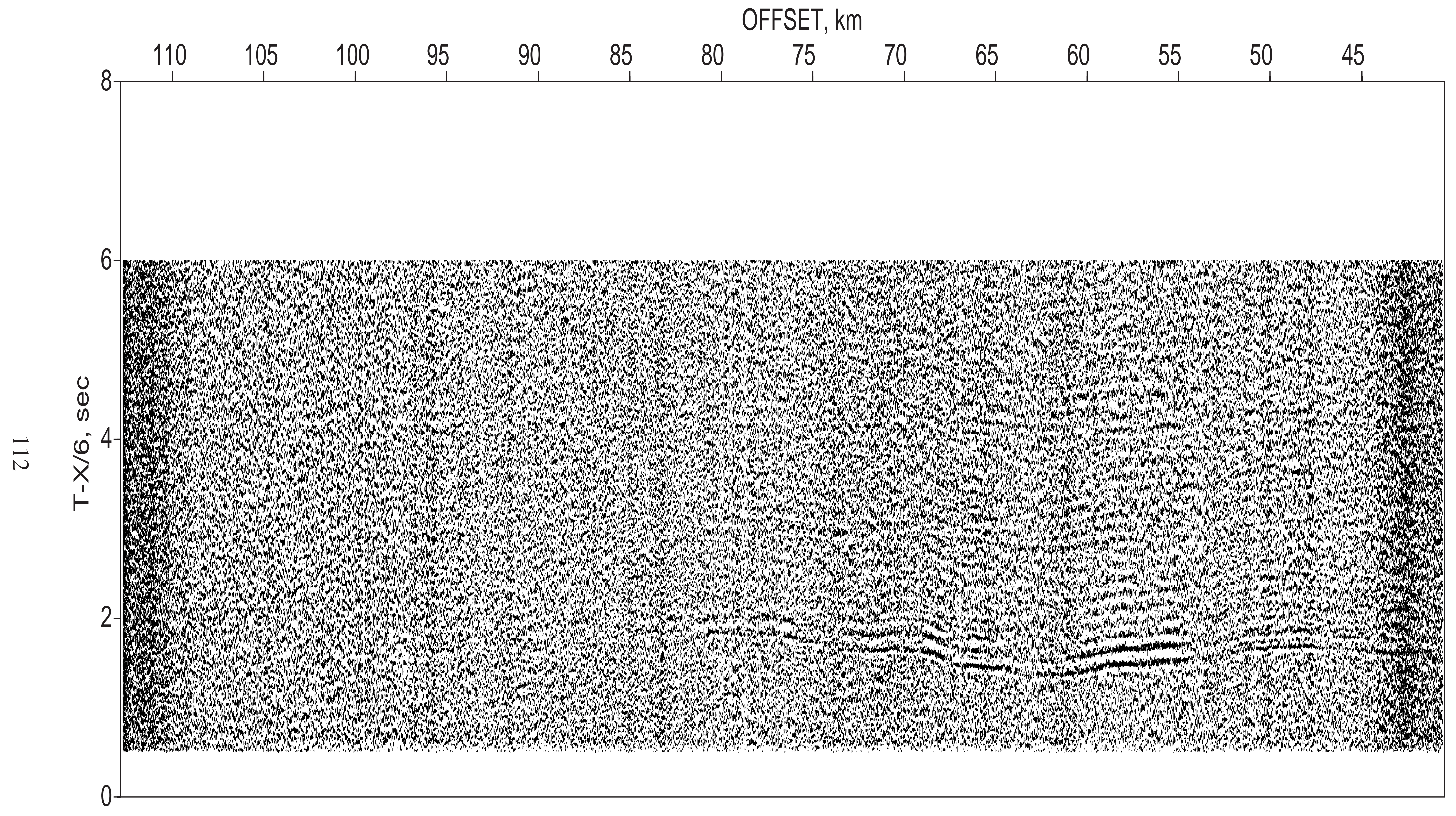

Figure 33. Record section for Reftek station 1011 for Line 9 in Puget Sound. 


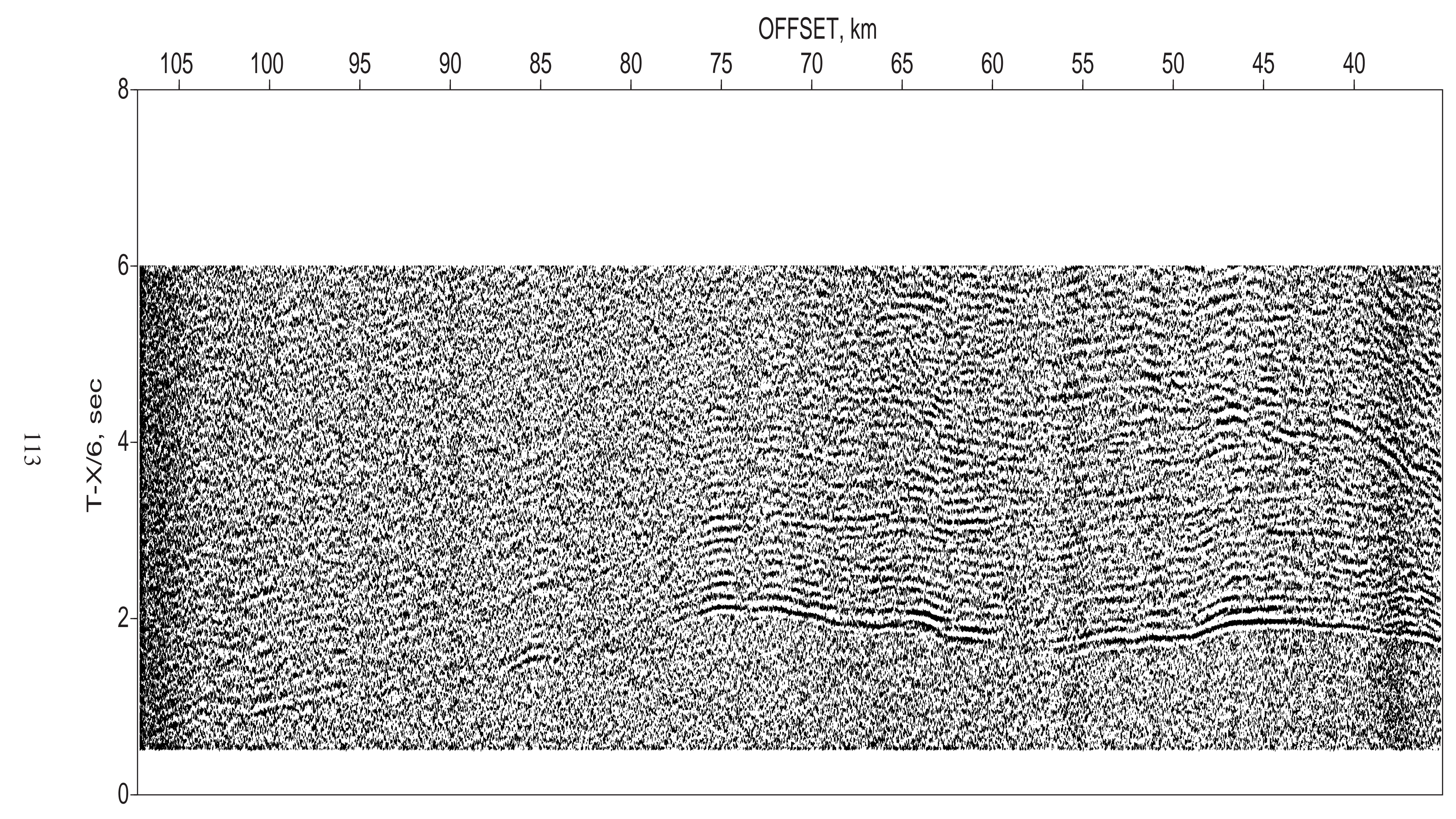

Figure 34. Record section for Reftek station 1012 for Line 9 in Puget Sound. 
South

North

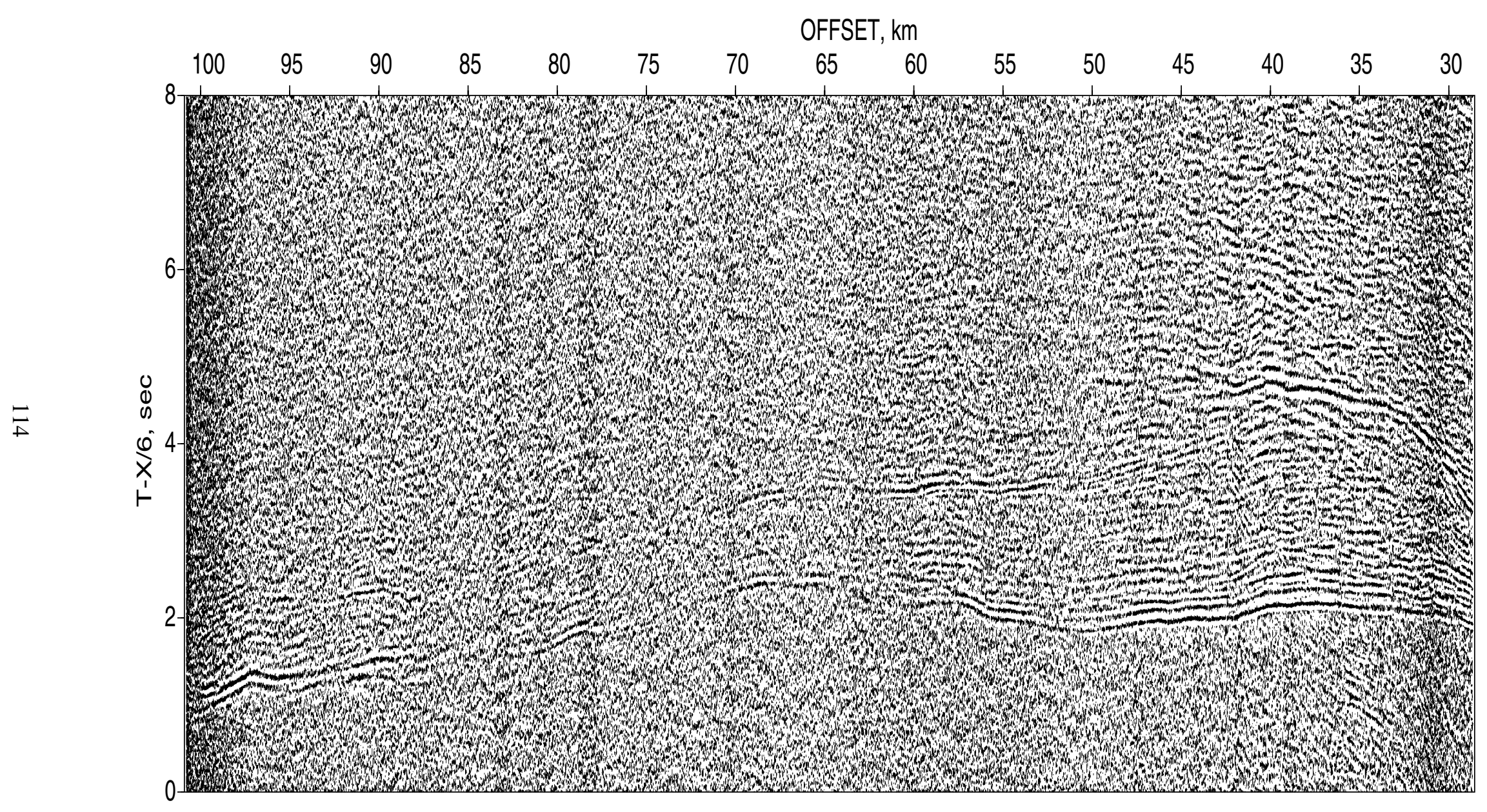

Figure 35. Record section for Reftek station 1013 for Line 9 in Puget Sound. 


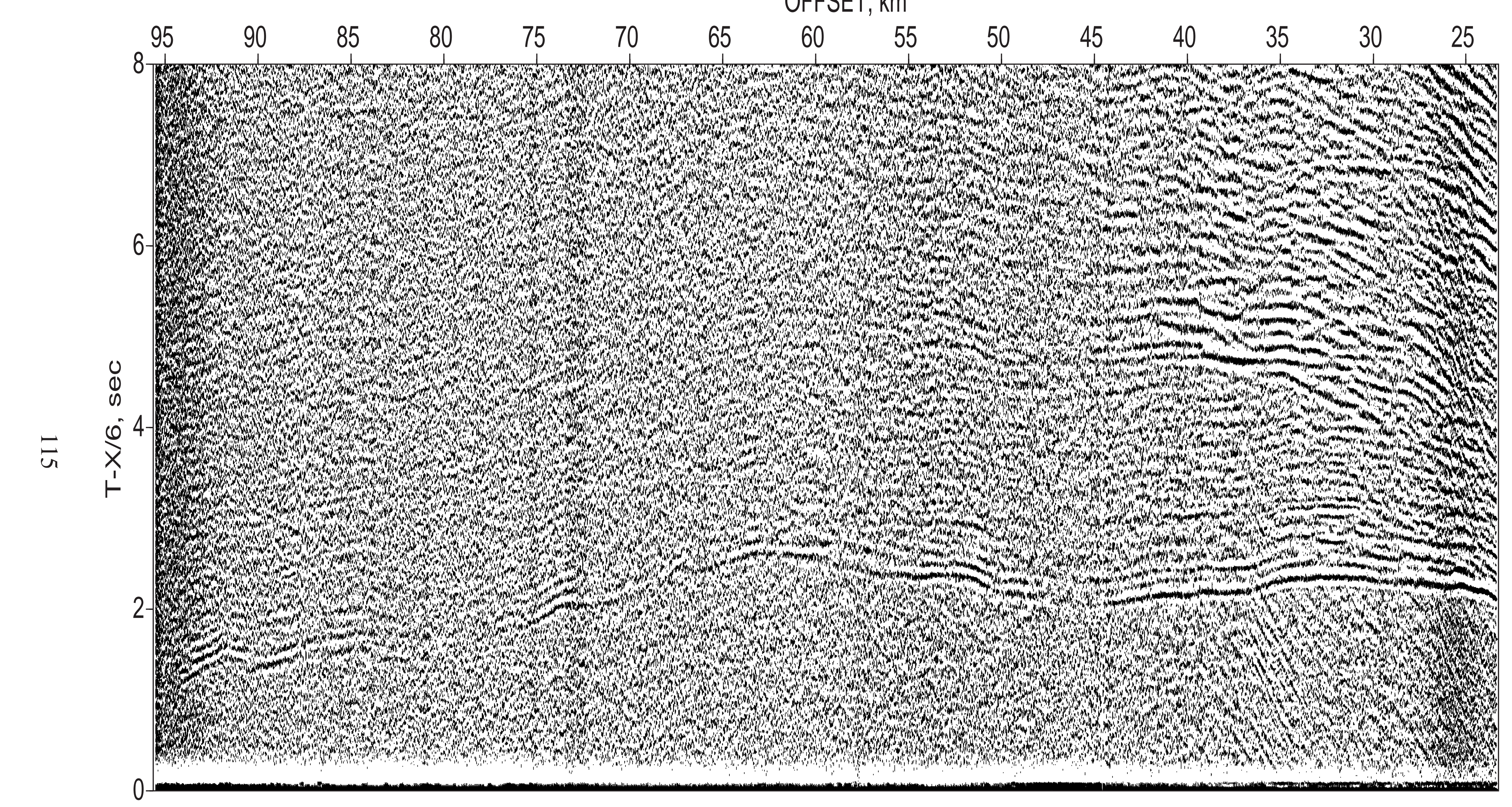

Figure 36. Record section for Reftek station 1014 for Line 9 in Puget Sound. 


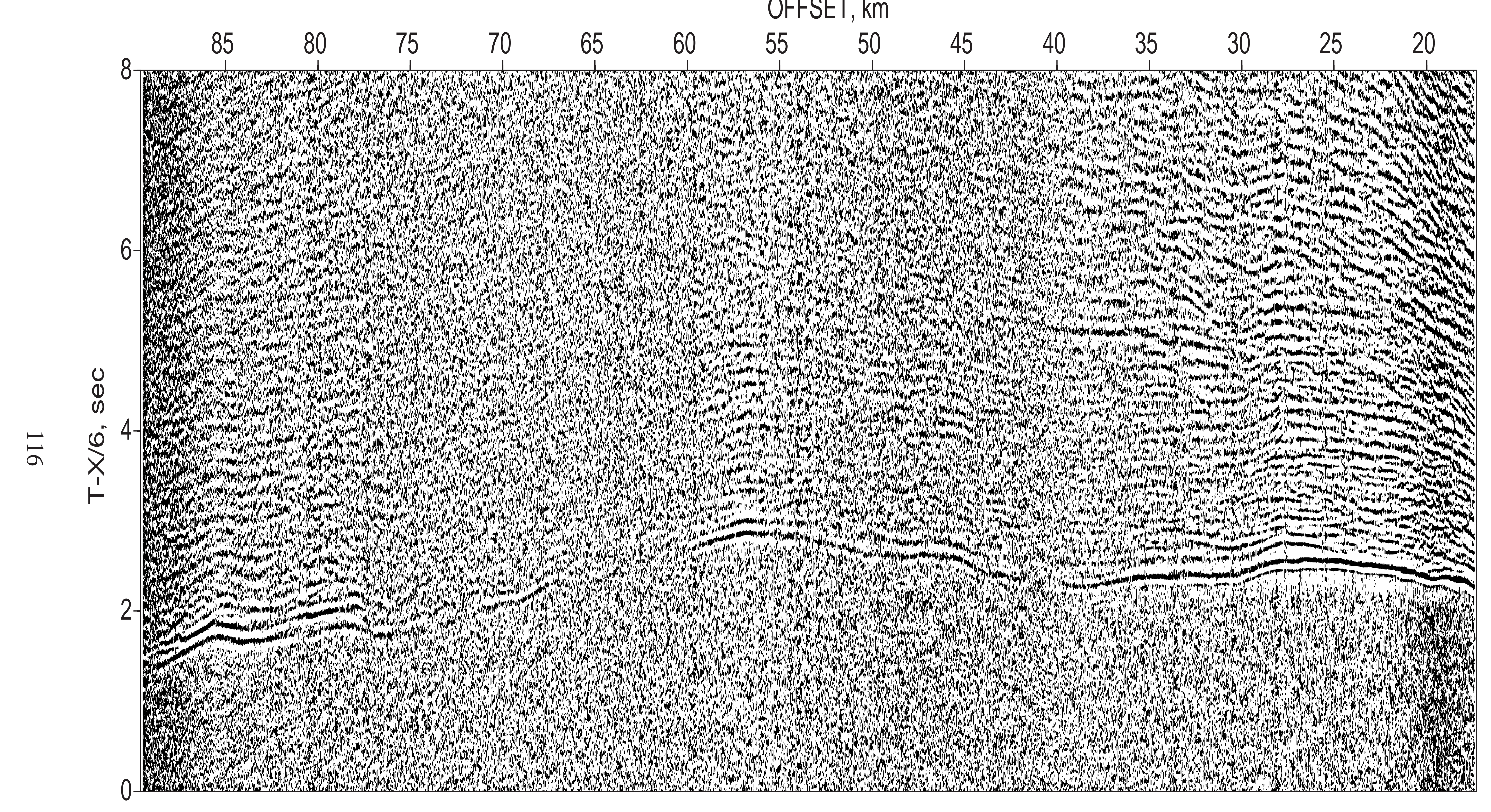

Figure 37. Record section for Reftek station 1015 for Line 9 in Puget Sound. 
OFFSET, km

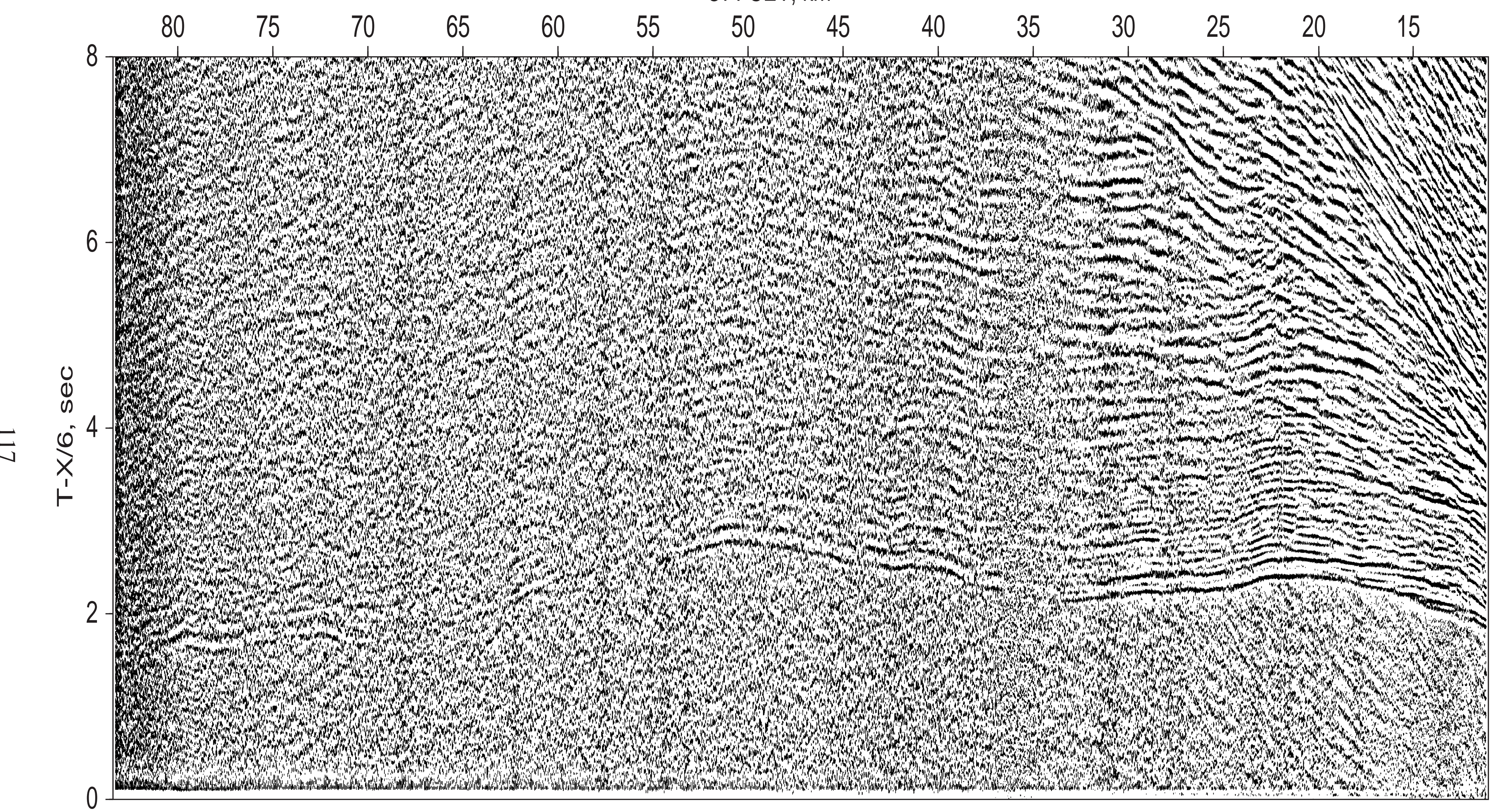

Figure 38. Record section for Reftek station 1016 for Line 9 in Puget Sound. 


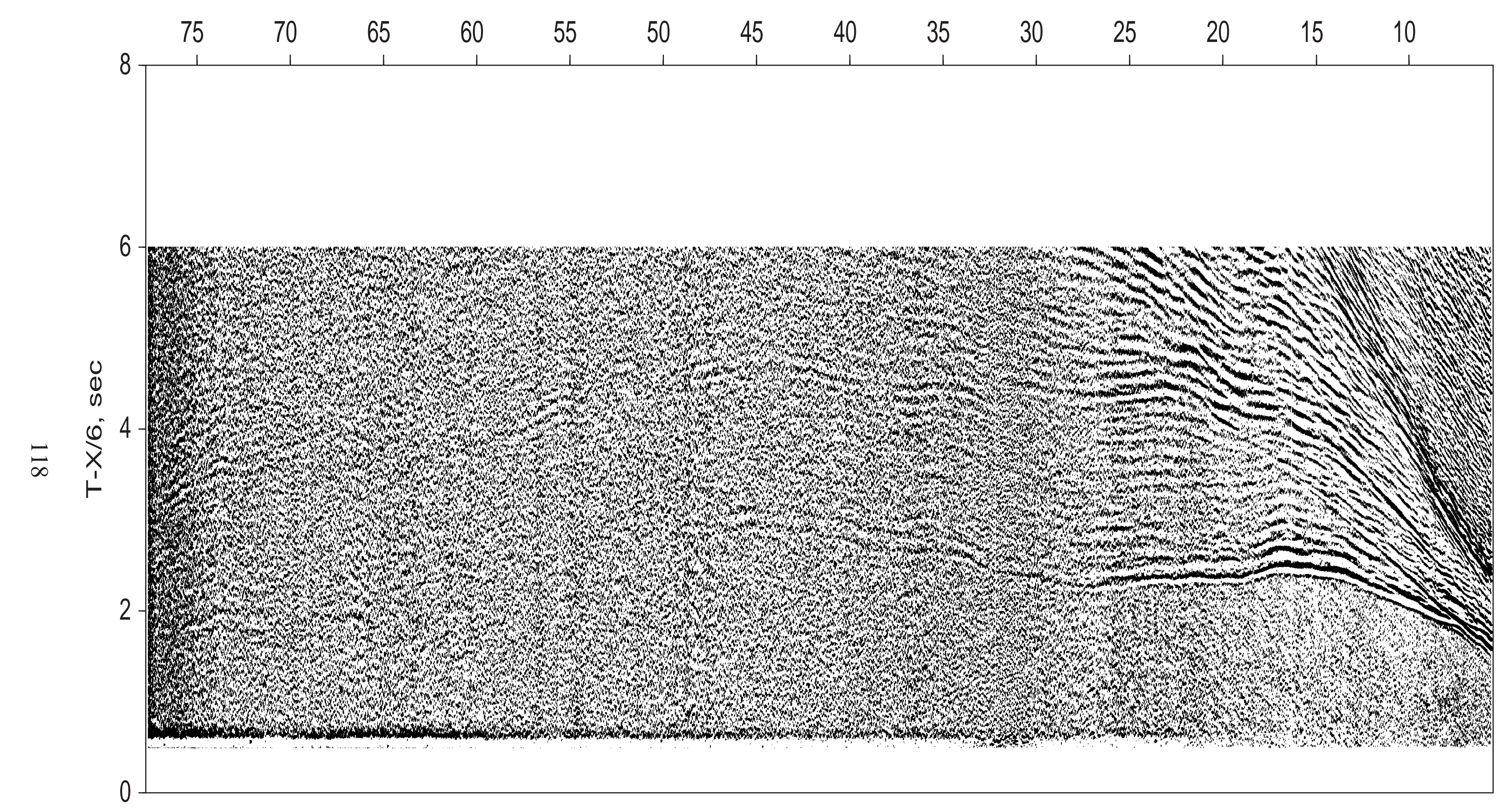

Figure 39. Record section for Reftek station 1017 for Line 9 in Puget Sound. 


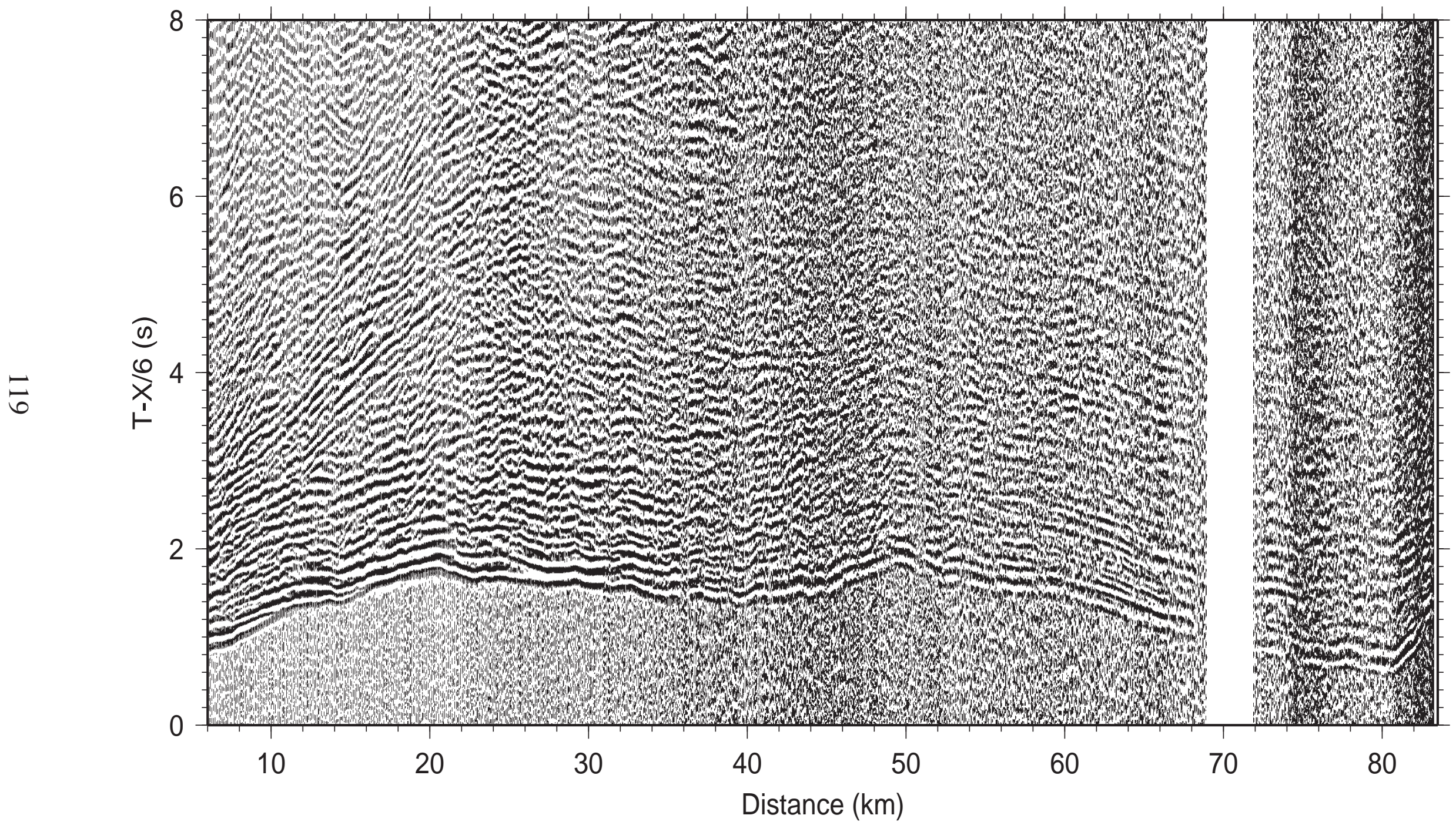

Figure 40. Record section for Reftek station 7007 for Line 3 in Hood Canal. 


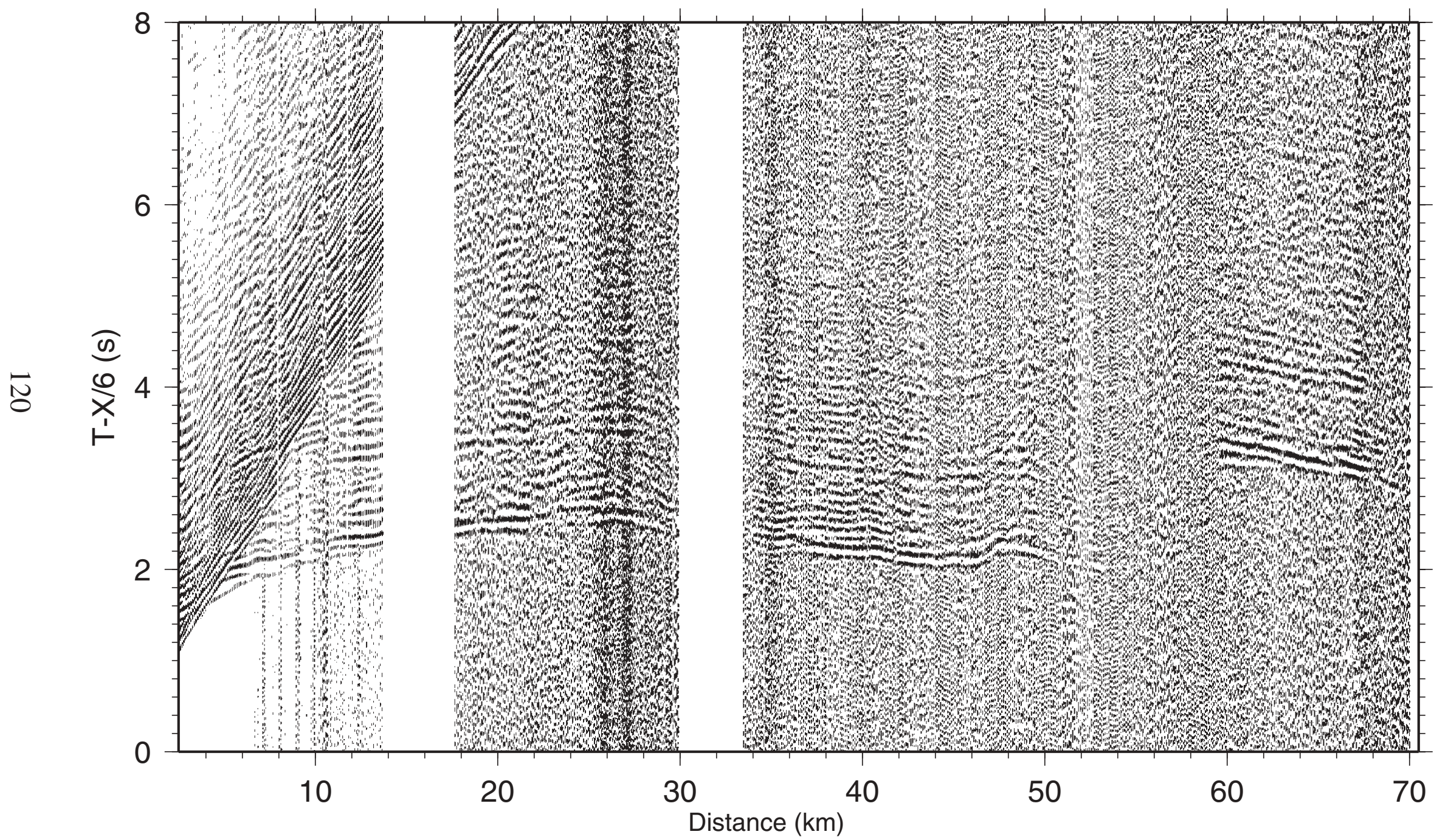

Figure 41. Record section for Reftek station 8003 for Line 2 in Puget Sound. 


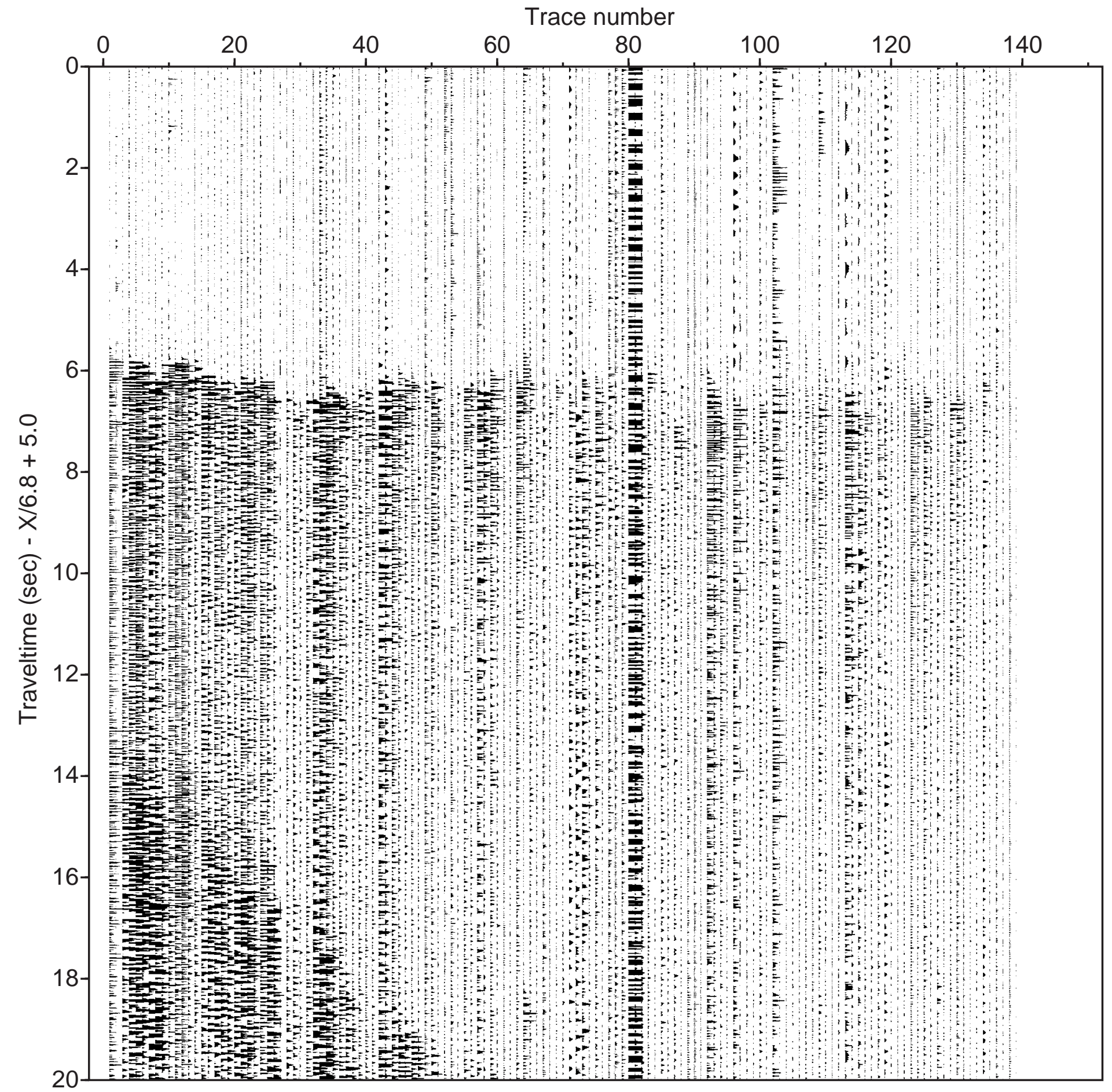

Earthquake 120006

Figure 42. Record section for the M2.8 earthquake event 120006, located $11.7 \mathrm{~km}$ WSW of Morton, Washington, at $16.9 \mathrm{~km}$ depth. Each trace represents a recording made by a different Reftek station. The traces are ordered from nearest to farthest from the event epicenter. 


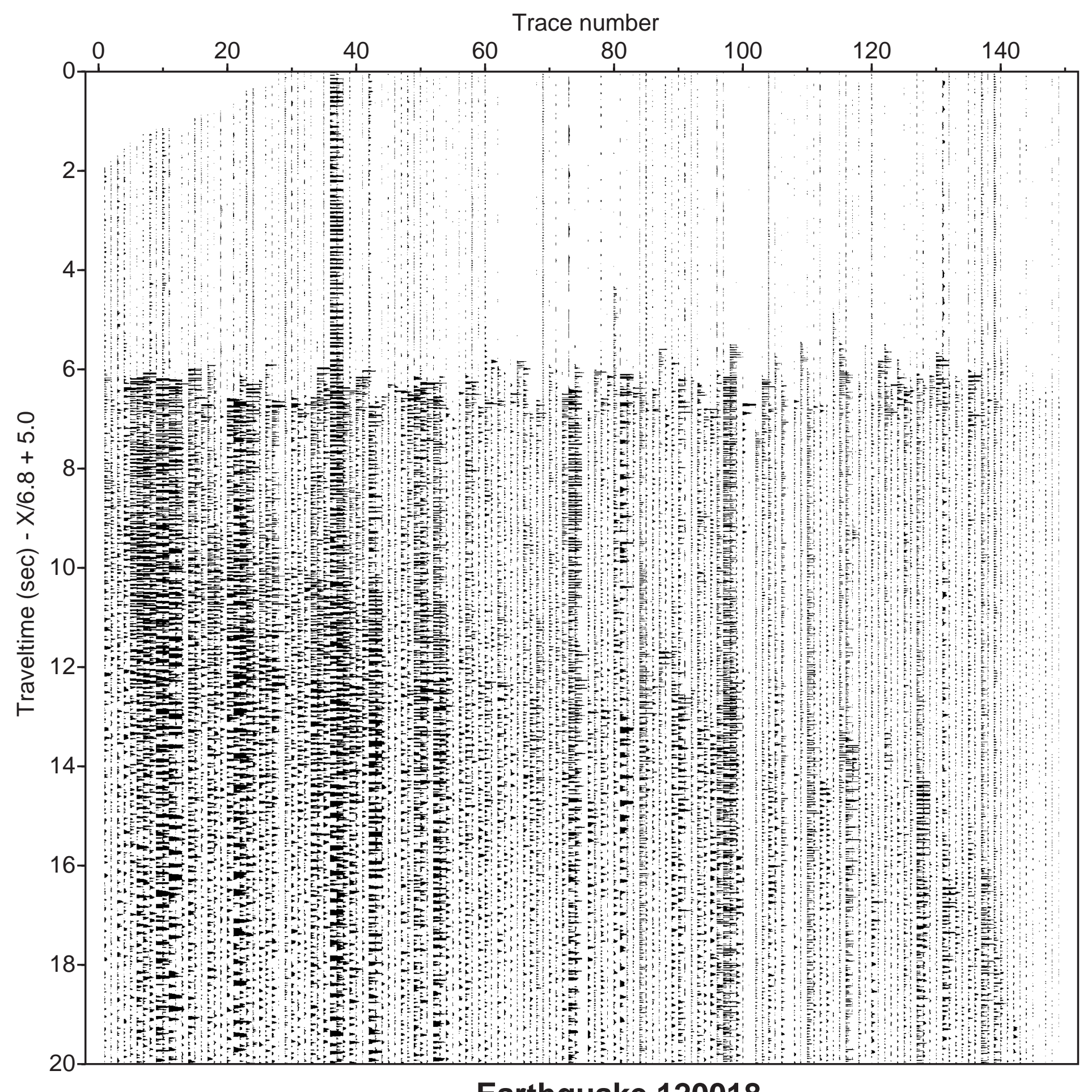

Earthquake 120018

Figure 43. Record section for the M2.3 earthquake event 120018, located $6.3 \mathrm{~km}$ SSW of Seattle, Washington, at $21.1 \mathrm{~km}$ depth. Each trace represents a recording made by a different Reftek station. The traces are ordered from nearest to farthest from the event epicenter. 


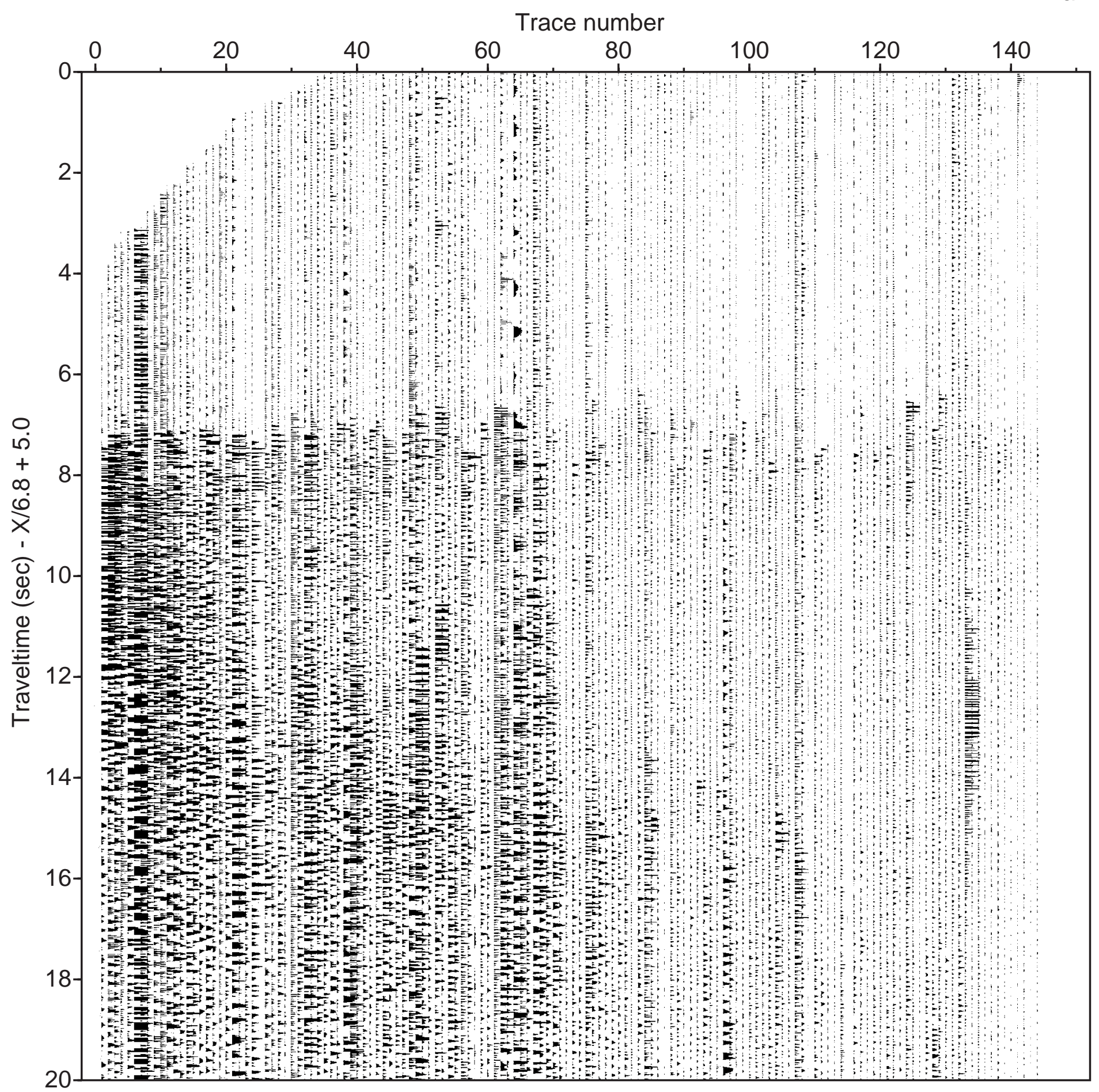

Earthquake 120028

Figure 44. Record section for the M2.1 earthquake event 120028, located $3 \mathrm{~km}$ ESE of Bellevue, Washington, at $2.8 \mathrm{~km}$ depth. Each trace represents a recording made by a different Reftek station. The traces are ordered from nearest to farthest from the event epicenter. 